\title{
Werkgelegenheid en scholing 1999
}

Citation for published version (APA):

Researchcentrum voor Onderwijs en Arbeidsmarkt, ROA. (2000). Werkgelegenheid en scholing 1999. Researchcentrum voor Onderwijs en Arbeidsmarkt, Faculteit der Economische Wetenschappen. ROA Reports No. 005 https://doi.org/10.26481/umarep.2000005

Document status and date:

Published: 01/01/2000

DOI:

10.26481/umarep.2000005

Document Version:

Publisher's PDF, also known as Version of record

\section{Please check the document version of this publication:}

- A submitted manuscript is the version of the article upon submission and before peer-review. There can be important differences between the submitted version and the official published version of record.

People interested in the research are advised to contact the author for the final version of the publication, or visit the DOI to the publisher's website.

- The final author version and the galley proof are versions of the publication after peer review.

- The final published version features the final layout of the paper including the volume, issue and page numbers.

Link to publication

\footnotetext{
General rights rights.

- You may freely distribute the URL identifying the publication in the public portal. please follow below link for the End User Agreement:

www.umlib.nl/taverne-license

Take down policy

If you believe that this document breaches copyright please contact us at:

repository@maastrichtuniversity.nl

providing details and we will investigate your claim.
}

Copyright and moral rights for the publications made accessible in the public portal are retained by the authors and/or other copyright owners and it is a condition of accessing publications that users recognise and abide by the legal requirements associated with these

- Users may download and print one copy of any publication from the public portal for the purpose of private study or research.

- You may not further distribute the material or use it for any profit-making activity or commercial gain

If the publication is distributed under the terms of Article $25 \mathrm{fa}$ of the Dutch Copyright Act, indicated by the "Taverne" license above, 


\title{
Werkgelegenheid en scholing 1999
}

\author{
ROA-R-2000/5
}

Researchcentrum voor Onderwijs en Arbeidsmarkt

Faculteit der Economische Wetenschappen en Bedrijfskunde Universiteit Maastricht

Maastricht, april 2000 
Niets uit deze uitgave mag worden verveelvoudigd en/of openbaar gemaakt door middel van druk, fotocopie, microfilm, of op welke wijze ook, zonder voorafgaande schriftelijke toestemming van de directeur van het Researchcentrum voor Onderwijs en Arbeidsmarkt. In geval van overname van het data-materiaal moet telkens als bron worden vermeld: "Researchcentrum voor Onderwijs en Arbeidsmarkt" of "ROA". Van publicaties waarin gebruik wordt gemaakt van gegevens uit dit rapport ontvangen wij gaarne een exemplaar.

Hoewel de grootst mogelijke zorg is besteed aan de inhoud van dit rapport, kan het ROA in generlei opzicht verantwoordelijkheid op zich nemen voor eventuele onvolledigheden of onjuistheden. 


\section{Inhoud}

Voorwoord

Resumé

1 Inleiding

2 Arbeidsomstandigheden 11

2.1 Inleiding 11

2.2 Belastende arbeidsomstandigheden, kans op kwalificatieveroudering en risico op verlies van werk

2.3 Arbeidsomstandigheden: fysieke en psychische belasting

2.4 RSI, een verhaal apart

2.5 Conclusies

3 Technologische en organisatorische ontwikkelingen

3.1 Inleiding

3.2 Enkele kengetallen 38

3.3 Ontwikkelingen op het gebied van Research \& Development 40

3.4 Informatie- en communicatietechnologie 43

$\begin{array}{ll}3.5 \text { Organisatorische ontwikkelingen } & 47\end{array}$

3.6 Computergebruik naar opleiding en beroep 55

3.7 Conclusies 57

4 Arbeidsmarktontwikkelingen $\quad 61$

4.1 Inleiding 61

4.2 Kwalificatieveroudering als gevolg van een krimpende werkgelegenheid of reallocatieprocessen

4.3 Functie-inhoudelijke kwalificatieveroudering $\quad 77$

$\begin{array}{ll}4.4 \text { Conclusies } & 79\end{array}$

5 Scholing en functionele flexibiliteit 83

5.1 Inleiding 83

5.2 Enkele feiten en cijfers over scholingsinspanningen 85

$\begin{array}{ll}5.3 \text { Scholingsinspanningen } & 87\end{array}$

5.4 Functionele flexibiliteit $\quad 92$

$\begin{array}{ll}5.5 \text { Conclusies } & 103\end{array}$

6 Risicoprofielen en doelgroepen $\quad 105$

6.1 Inleiding 105

$\begin{array}{ll}6.2 \text { Risicoprofielen } & 105\end{array}$

6.3 Potentiële doelgroepen 113

$\begin{array}{lr}6.4 \text { Conclusies } & 123\end{array}$ 
7 Scholing voor behoud van werk 


\section{Voorwoord}

Werkgelegenbeid en scholing 1999 en de bijbehorende Statistiscbe Bijlage is na Werkgelegenbeid en scholing 1996 en 1997 de derde versie van een overzichtsrapport in het kader van het Werkgelegenheid en Scholing Observatorium (WSO) van het Researchcentrum voor Onderwijs en Arbeidsmarkt (ROA). Dit observatorium is door het Ministerie van Sociale Zaken en Werkgelegenheid ingesteld in het kader van de stimuleringsprogramma's ESF-4 Scholing voor beboud van werk en ADAPT van de Europese Commissie.

Het observatorium heeft als doel de voor het scholingsbeleid relevante ontwikkelingen in beeld te brengen. Het WSO fungeert daarbij als een centraal punt, waar de relevante ontwikkelingen en prognoses met betrekking tot de werkgelegenheid en kwalificatiebehoeften met elkaar in verband worden gebracht, om zo tijdig inzicht te krijgen in de scholingsactiviteiten binnen branches en bedrijven en de lacunes die op dit punt optreden.

Het observatorium-karakter van dit rapport wordt weerspiegeld door het grote aantal indicatoren dat de revue passeert. Deze kengetallen hebben steeds als doel opvallende factoren of ontwikkelingen te signaleren. Aan de hand van deze indicatoren worden in de hoofdstukken 2, 3, 4 en 5 stapsgewijs de relevante factoren voor het scholingsbeleid dat gericht is op het behoud van werk gepresenteerd. In de hoofdstukken 6 en 7 worden vervolgens de belangrijkste kengetallen aan elkaar gerelateerd, om op deze wijze de grootste additionele scholingsbehoeften in kaart te brengen. Omdat dit derde overzichtsrapport moet worden beschouwd als het sluitstuk van de monitoring in het kader van het huidige ESF programma, wordt in hoofdstuk 8 ten slotte een beeld geschetst van de resultaten die het observatorium tot op heden heeft opgeleverd en de mogelijkheden ervan in de toekomst.

Voor de in dit overzichtsrapport gebruikte indicatoren zijn steeds drie invalshoeken van belang: bedrijfssector, beroep en opleiding. Daarnaast wordt in een aantal gevallen ook verbijzonderd naar bedrijfsgrootte. Bij een aantal indicatoren legt de gebruikte databron beperkingen op aan de presenteerbaarheid van de gegevens. Zo zijn gegevens op een laag aggregatieniveau afkomstig uit de Enquêle Beroepsbevolking van het CBS beperkt presenteerbaar als gevolg van publicatie-restricties. Indicatoren op laag aggregatieniveau uit het OSA-aanbodpanel worden vaak onbetrouwbaar als gevolg van de beperkte omvang van het aantal respondenten. Daarom is als uitgangspunt genomen dat indicatoren gepresenteerd worden op het laagst mogelijke aggregatieniveau waarbij betrouwbaarheid en volledigheid nog gewaarborgd zijn.

Dit heeft tot gevolg dat de indicatoren in het rapport soms verschillen qua aggregatieniveau. Zo staan er in het rapport bijvoorbeeld zowel gegevens met betrekking tot bedriffssectoren op een laag aggregatieniveau ( 35 sectoren) als op een hoog aggregatieniveau (13 sectoren). Indicatoren per beroep worden zelfs op drie verschillende niveaus gepresenteerd. Indien mogelijk wordt uitgegaan van een gedetaillecrde indeling in 127 beroepsgroepen. In andere gevallen wordt een beknopte indeling in 43 
beroepssegmenten gebruikt. In een enkel geval worden gegevens gepresenteerd op het hoge niveau van 11 beroepssectoren. Ook indicatoren per opleiding komen zowel op het lage niveau van 104 opleidingstypen als op het hogere aggregatieniveau van 28 opleidingsrichtingen aan de orde.

De gepresenteerde indicatoren worden telkens ook kwalitatief getypeerd, uiteenlopend van 'erg laag' tot 'erg hoog'. Daarbij gaat het in de meeste gevallen om een relatieve typering ten opzichte van de andere bedrijfsgroottes, bedrijfssectoren, beroepen of opleidingen.

In de hoofdstukken 6 en 7 wordt een aantal belangrijke indicatoren gecombineerd om de risico's op verlies van werk in kaart te brengen. Om de verschillende indicatoren te kunnen combineren, worden in deze hoofdstukken telkens de classificaties op het hogere aggregatieniveau gebruikt. Voor de als potentiële doelgroepen voor het scholingsbeleid geïdentificeerde beroepen en opleidingen worden vervolgens de (eventuele) scholingstrajecten aangegeven die de beste kansen bieden op het behoud van werk.

De bij het rapport horende Statistische Bijlage heeft twee doelen. Enerzijds wordt er een totaaloverzicht gegeven van de in het rapport besproken indicatoren voor alle onderscheiden bedrijfsgroottes, bedrijfssectoren, beroepen en opleidingen. Anderzijds worden veel indicatoren gepresenteerd op een aggregatieniveau dat niet in het rapport wordt onderscheiden. De Statistische Bijlage is ditmaal geordend volgens de hoofdstukindeling die ook in het rapport is gehanteerd. Op deze wijze kan de Statistische Bijlage waarschijnlijk het meest adequat fungeren als naslagwerk.

De projectleiding van het WSO is in handen van Prof. dr. A. de Grip. Drs. J.M.A.F. Sanders speelde een centrale rol bij de uitvoering van het onderzoek en de totstandkoming van de rapportage. Aan het rapport is verder meegewerkt door R. van Dijk, lng. N. van Hal, drs. A.G.M. Jacobs, drs. Ph.S. Marey en drs. M.J. de Steur. Onze dank gaat bovendien uit naar de leden van de begeleidingscommissie bij het Ministerie van Sociale Zaken en Werkgelegenheid, te weten: drs. F. Straatjes en drs. J.C. van der Velden. 


\section{Resumé}

Werkgelegenbeid en scboling 1999 en de bijbehorende Statistische Bijlage is de derde rapportage in het kader van het Werkgelegenheid en Scholing Observatorium (WSO). Doel van het observatorium is het in beeld brengen van de voor het scholingsbeleid van werkenden relevante ontwikkelingen en de risico's op verlies van werk die deze ontwikkelingen met zich meebrengen. Ontwikkelingen die hierbij vooral van belang zijn, zijn ontwikkelingen op het gebied van de arbeidsomstandigheden, technologische en organisatorische ontwikkelingen en arbeidsmarktontwikkelingen. Bij het scholingsbeleid gericht op het behoud van werk staan twee vragen centraal:

1. Welke groepen werkenden lopen als gevolg van kwalificatieveroudering een risico op verlies van werk?

2. Welke scholingsactiviteiten bieden deze werkenden betere kansen op de arbeidsmarkt?

\section{Risicofactoren}

In dit rappont wordt ingegaan op drie centrale risicofactoren waar werkenden in meer of mindere mate mee worden geconfronteerd. Hierbij gaat het om achtereenvolgens:

- fysiek of psychisch belastende arbeidsomstandigheden en risico's van RSI (hoofdstuk 2);

- technologische en/of organisatorische ontwikkelingen (hoofdstuk 3);

- ongunstige arbeidsmarktontwikkelingen: werkgelegenheidskrimp of reallocatie (hoofdstuk 4).

Bovendien wordt er gekeken naar factoren die het risico op verlies van werk als gevolg van kwalificatieveroudering voor bepaalde groepen werknemers versterken, zoals relatief veel flexibele arbeidscontracten of een oververtegenwoordiging van oudere werknemers.

Wanneer iemand als gevolg van fysiek en/of psychisch belastende arbeidsomstandigheden niet langer in staat is zijn of haar beroep uit te oefenen, zal omscholing naar een andere, minder belastende, functie noodzakelijk zijn. Ook kan additionele scholing op het gebied van computergebruik, werkhouding en bijvoorbeeld time-management het risico op verlies van werk als gevolg van fysieke of psychische belasting verminderen.

Technologische en organisatorische ontwikkelingen kunnen leiden tot functiespecifieke kwalificatie-veroudering. Een mogelijke remedie hiertegen is bijscholing: het uitbouwen van bestaande kennis of vaardigheden ten behoeve van de functie die een individu vervult. Substantiële bijscholing is vereist wanneer er voor een bepaald beroep een hoger opleidingsniveau wordt vereist dan in het verleden (bv. een MBO-opleiding in plaats van een $\mathrm{V}(\mathrm{M}) \mathrm{BO}-$ opleiding.

Als er ten slotte sprake is van kwalificatie-veroudering door arbeidsmarktontwikkelingen, is omscholing naar een ander beroep of hetzelfde soort beroep in een andere bedrijfssector meer op zijn plaats. Om na te gaan wat de potentiële doelgroepen voor het scholingsbeleid gericht op behoud van werk zouden moeten zijn, is nagegaan in 
hoeverre bij verschillende groepen werkenden de huidige scholingsdeelname en de functionele flexibiliteit van werkenden tegenwicht bieden aan de bovengenoemde risicofactoren. De functionele flexibiliteit wordt hierbij gemeten aan de hand van een tweetal factoren: mobiliteit en inzetbaarheid. Elk met twee dimensies: iemands vermogen en iemands bereidheid. Ten slotte wordt voor de gesignaleerde potentiële doelgroepen waarvoor omscholing of substantiële bijscholing vereist is, aangegeven welke scholingstrajecten hun arbeidsmarktperspectief zouden kunnen verbeteren.

\section{Arbeidsomstandigheden}

Arbeidsomstandigheden kunnen een belangrijke rol spelen bij kwalificatie-veroudering door fysieke of psychische slijtage van werkenden. In hoofdstuk 2 worden drie fysiek belastende arbeidsomstandigheden (kracht zetten, werken in lawaaierige omstandigheden en trillingen tijclens het werk) en één psychische belastingsfactor (tijdsdruk) nader belicht. Ook wordt het werken in ploegendienst als risicofactor uitgelicht. Werken in ploegendienst brengt immers zowel fysieke als psychische belasting met zich mee. Bovendien wordt meer specifiek ingegaan op RSI als arbeidsgerelateerd risico op verlies van werk. Hierbij is zeker niet alleen de zogeheten 'muisarm' van belang, maar vooral ook psychische factoren, zoals een gebrek aan beslissingsvrijheid en bijvoorbeeld een slechte werksfeer, en fysieke factoren, zoals het uitvoeren van zeer repetitieve werkzaamheden in het algemeen.

Vooral in de sectoren botw, veehouderij en metaalproducten is er sprake van een erg hoge fysieke belasting. Deze sectoren worden al van oudsher gekenmerkt door fysiek zware arbeid. Er wordt immers veel met zware materialen en machines gewerkt. Dit blijkt ook als wordt gekeken naar de beroepssegmenten waarin werkenden met hoge fysieke belasting te kampen hebben. Weg- en waterbouwkundige arbeiders, bouwakkers en metaalarbeiders worden het meest belast.

Psychische belasting in de vorm van tijdsdruk is vooral een belangrijke risicofactor in de scheep-en livchwaart, de grafische industrie en het bankwezen. De beroepsgroepen die te maken hebben met een relatief hoge psychische belasting zijn met name stewards, journalisten en informatici. In lhet algemeen zijn het de werkenden met een lagere of middelbare technische opleiding die te maken krijgen met fysiek belastende arbeidsomstandigheden. Psychische belasting in de vorm van het werken onder tijdsdruk treft daarentegen vooral werkenden met een hogere opleidingsachtergrond.

Van de tien opleidingstypen waarvoor geldt dat de tijdsdruk erg hoog is hebben er negen een universitair niveau en één een HBO-niveau. Werkenden met een opleiding WO informatica en besturlijke informatiekunde hebben het meest met tijdsdruk te maken. Gevolgd door werkenden met een opleiding WO accountancy en belastingen.

RSI batat vooral werkenden in de sectoren boreca, bouw en landbouw, jachl en bosbouw zorgen. De beroepen die nar voren komen wit de twee andere studies die in het rapport de revue passeren zijn vooral beroepen op lager niveau. De werkenden in de elementaire beroepen lopen het grootste RSI-risico, gevolgd door andere van oudsher "zware' beroepsgroepen als laders, lossers en impakkers en metselaars, timmerlieden en bowwakkers. Een andere beroepsgroep die op dit punt een duidelijke risicogroep 
vormt zijn de naai(st)ers. Zij doen weliswaar niet zo'n zwaar werk, maar zijn over het algemeen wel erg repetitief bezig.

In hoofdstuk 3 wordt aandacht besteed aan informatisering als risicofactor met betrekking tot functie-inhoudelijke kwalificatieveroudering. Het toenemende computergebruik heeft echter ook vergaande gevolgen voor de fysieke gesteldheid van werkenden. RSI wordt niet voor niets vooral gekoppeld aan beeldschermwerk en een aantal RSI-achtige ziekteverschijnselen, zoals de 'muisarm' is direct toewijsbaar aan het gebruik van computers. Omdat het voornamelijk de hoger opgeleiden zijn die veel met computers werken, bestaat ook voor deze groepen werkenden een verhoogd risico om als gevolg van fysieke slijtage hun baan te verliezen. Vooral informatici en systeemanalisten behoren wat dit betreft tot de aandachtsgroepen. Daarbij zijn het de werkenden met een opleiding WO informatica en bestuurlike informatiekunde en HBO informatica die het meest worden blootgesteld aan de risico's van RSI als gevolg van veelvuldig computergebruik.

\section{Technologische en organisatorische ontwikkelingen}

Technologische en organisatorische ontwikkelingen kunnen de werkgelegenheid van groepen werkenden bedreigen, wanneer ze door deze ontwikkelingen niet meer beschikken over de voor een adequate uitoefening van hun functie vereiste kwalificaties. Om een goed inzicht te krijgen in de mogelijke risico's die werkenden op dit punt lopen, worden in dit rapport ontwikkelingen op een drietal gebieden in beeld gebracht, te weten:

- Informatie en Communicatie Technologie (ICT);

- Research \& Development;

- Organisatorische veranderingen.

De grote bedrijven met meer dan 100 werknemers lopen op het gebied van de technologische en organisatorische vernieuwingen in het algemeen voor op het midden- en kleinbedrijf. Wel valt op dat zowel het midden-, als het kleinbedrijf op ICT-gebied bezig zijn met een inhaalslag. Sinds 1997 zijn in het midden- en kleinbedrijf de ICT-ontwikkelingen sneller gegaan dan in de grote bedrijven.

De werkenden in de sector overhetd en onderwijs worden relatief veel met technologische en organisatorische veranderingen geconfronteerd. Hetzelfde geldt voor de werkenden in de kwartaire diensten en de chemie. In deze sectoren is vooral veel aandacht voor R\&D. Dit is ook het geval in de voedingssector. In de kwartaire diensten is vooral veel sprake van organisatorische veranderingen. In de sector chemie vormen met name ICT-ontwikkelingen een belangrijke risicofactor voor het optreden van kwalificatieveroudering. Hetzelfde geldt voor werkenden in het bank-en verzekeringswezen. De werkenden in de sector energie lopen met name risico op verlies van werk doordat op organisatorisch vlak veel verandert.

Om een indruk te krijgen van de beroepsgroepen en opleidingstypen die het meest geconfronteerd worden met technologische vernieuwingen is gekeken naar het percentage werkenden dat met informatisering te maken heeft. De informatiseringsgraad is 
vooral erg hoog voor functies waarin hoger opgeleiden werken. Van de grafisch ontwerpers, taalkundigen, organisatiedeskundigen, systeemanalisten en informatici werkt bijna $100 \%$ met een computer. Werkenden met een opleiding WO informatica en bestuurlifke informatiekunde, HBO informatica, WO elektrotechniek, MBO geld, bank en belastingen of WO werktuigbouwkunde hebben te maken met een zeer hoge mate van informatisering.

\section{Arbeidsmarktontwikkelingen}

In verschillende bedrijfssectoren wordt voor de komende jaren een krimp in de werkgelegenheid verwacht. Dit geldt met name voor de sectoren landbouw en visserij, voeding, metaal- en elektrotechniek en overige industrie. De daling van de werkgelegenheid doet zich vooral voor in de lagere niet-specialistische beroepen en lagere en middelbare agrarische en techniscbe beroepen. Bij de lagere en middelbare agrarische en technische beroepen is er bovendien sprake van een relatief grote verschuiving van een deel van de werkgelegenheid naar andere bedriffssectoren, waardoor werkenden gedwongen zullen worden van baan te veranderen. Vooral werkenden in de lagere en middelbare agrarische beroepen in de sector landbouw en visserij zullen op termijn waarschijnlijk worden geconfronteerd met een mogelijk verlies van werk. Een deel van deze groep werkenden zou echter in een sector waar sprake is van baancreatie voor deze beroepsgroep weer aan de slag kunnen.

Deze 'reallocatie' van de werkgelegenheid doet een groot beroep op de employability van de werkenden in deze beroepen en vereist waarschijnlijk aanzienlijke scholingsinspanningen om het risico op verlies van werk te beperken. Dit laatste geldt ook voor werkenden in de lagere verzorgende beroepen, waar een relatief grote vraagafname eveneens wordt gecombineerd met een verschuiving van de werkgelegenheid naar andere bedrijfssectoren. In de sector kwartaire diensten bijvoorbeeld verdwijnt bijna $13 \%$ van de banen voor deze beroepsgroep. Ruim 5\% van dit verlies wordt opgevangen, doordat in andere sectoren banen voor deze beroepsgroep worden gecreëerd. Bij de elementaire beroepen is er ook sprake van een grote verschuiving van de werkgelegenheid. Vooral vanuit de sectoren overbeid en onderwijs en bouw en onroerend goed zullen veel werkenden in de elementaire beroepen worden gerealloceerd.

De vraag naar arbeidskrachten met alleen basisonderwijs of een VMBO-opleiding zal naar verwachting de komende jaren fors afnemen. Met name naar werkenden met een technische VMBO-opleiding komt steeds minder vraag. Ook kriggen deze groepen werkenden te maken met een verschuiving van de werkgelegenheid naar andere bedriffssectoren, waardoor bedrijfsspecifieke kwalificaties hun waarde verliezen. Werkenden met slechts basisonderwijs of een VMBO-opleiding zijn bovendien werkzaam in functies waarvoor steeds hogere eisen worden gesteld. Men spreekt in dit verband doorgaans van een 'upgrading' van de kwalificatievereisten. In steeds meer uitvoerende beroepen komt het vereiste kwalificatieniveau op MBO-niveau te liggen, waardoor de lager opgeleiden in deze functies geconfronteerd worden met functie-inhoudelijke kwalificatieveroudering. Voor bijvoorbeeld lagere en middelbare agrarische, technische en verzorgende beroepen wordt de komende jaren aanzienlijk minder vraag verwacht naar werkenden met een opleiding basisonderwijs of een opleiding op VMBO-niveau. Het risico op verlies van werk bij lager opgeleiden wordt ten slotte nog versterkt door het feit dat 
laag opgeleide werknemers verhoudingsgewijs vaak onder een flexibel contract werkzaam zijn.

\section{Scholing en functionele flexibiliteit}

Evenals bij investeringen in gebouwen en machines kan bij investeringen in menselijk kapitaal een onderscheid gemaakt worden tussen uitbreidings- en vervangingsinvesteringen. Bij uitbreidingsinvesteringen wordt nieuw menselijk kapitaal verworven. Vervangingsinvesteringen hebben tot doel aanwezig menselijk kapitaal 'up to date' te houden en kwalificatieveroudering te voorkomen. Deze laatste investeringsvorm staat centraal bij het beperken van het risico op verlies van werk. Investeren in scholing is zonder twijfel de meest voor de hand liggende manier om het aanwezige menselijke kapitaal te onderhouden. Ook de functionele flexibiliteit van werkenden speelt op dit punt echter een belangrijke rol, omdat kwalificaties niet enkel door formele scholing in de vorm van bijvoorbeeld cursussen worden onderhouden, maar ook door een brede inzetbaarheid van werkenden. Deze brede inzetbaarheid zorgt er immers voor dat werkenden multi-inzetbaar worden, waardoor men minder kwetsbaar is voor plotseling optredende veranderingen in de vereiste kwalificaties in een specifiek functiegebied.

Het percentage oudere werknemers dat deelneemt aan opleidingen ligt een stuk lager dan het percentage jongere werknemers. Partimers nemen minder deel aan cursussen dan fulltimers en mensen met een vast contract volgen duidelijk meer aanvullende scholing dan werkenden met een tijdelijk contract. Wanneer werkenden met een tijdelijk contract echter uitzicht hebben op een vast contract, dan volgen zij juist weer meer scholing dan werkenden die al een vast contract hebben.

In de grote bedrijven (100 of meer werkenden) nemen werkenden vaker deel aan specifieke bedrijfsopleidingen dan in de middelgrote en kleine bedrijven. Bij de opleidingen die niet specifiek gericht zijn op het bedrijf zelf, is het verschil tussen grote, middelgrote en kleine bedrijven een stuk kleiner. In de middelgrote bedrijven is het deelnamepercentage aan dergelijke opleidingen zelfs iets groter dan dat in de grote bedrijven. Vooral de sectoren landbouw en visserij, overige industrie en transport en communicatie worden gekenmerkt door een lage scholingsdeelname. Daarbij zijn het vooral de werkenden in de middelbare agrarische beroepen en lagere transportheroepen die relatief weinig aan scholing doen. Als gekeken wordt naar de opleidingsachtergrond van de werkenden, zijn het vooral werkenden met een opleiding MBO landbouw en natuurlijke omgeving, VMBO zorg en welzijn, VMBO landbouw en natuurlijke omgeving of basisondenvis die weinig aan scholingsactiviteiten deelnemen.

De functionele flexibiliteit van werkenden wordt aan de hand van een viertal indicatoren in beeld gebracht, te weten: mobiliteitsbereidbeid, mobiliteitsvermogen, inzetbereidheid en inzetvermogen. Vooral in de grote bedrijven blijkt de functionele flexibiliteit van de werkenden gering. De bedrijfssectoren waar de functionele flexibiliteit van werkenden het geringst is zijn overbeid en onderwijs, kwartaire diensten en rransport en communicatie. Het zijn daarbij vooral de werkenden in de middelhare agrarische, lagere verzorgende, lagere (para)medische en bogere pedagogische beroepen (leerkrachten e.d.) die qua functionele flexibiliteit achterblijven. Wordt naar de opleidingsachtergrond gekeken dan blipken werkenden met VMBO zorg en welzim, basisondenwijs, VMBO techniek of WO letteren en theologie het minst functioneel flexibel. 


\section{Risicoprofielen en doelgroepen}

In hoofdstuk 6 worden de risico's op verlies van werk als gevolg van kwalificatie-veroudering afgezet tegen de feitelijke scholingsdeelname en de functionele flexibiliteit van werkenden. De risico's op verlies van werk zijn met behulp van zogenaamde risicoprofielen in beeld gebracht.

In deze risicoprofielen is in een oogopslag te zien in hoeverre groepen werkenden blootstaan aan elk van de vier onderscheiden risicofactoren. Ook is te zien in welke mate groepen werkenden zich tegen deze risico's wapenen via scholing en functionele flexibiliteit, de belangrijkste remedies tegen kwalificatieveroudering en verlies van werk.

Fysiek belastende arbeidsomstandigheden vormen, gezien de relatief geringe scholingsdeelname en functionele flexibiliteit van de werkenden, vooral een risico in de sectoren bouw en onroenend goed en metaal- en elektrotechniek. Met name de werkenden in de lagere technische, elementaire en de lagere en middelbare verzorgende beroepen behoren vanuit deze optiek tot de potentiële doelgroepen voor het scholingsbeleid. Het gaat hierbij voornamelijk om werkenden met een opleiding VMBO techniek, VMBO landbouw en natuurlijke omgeving, basisonderwijs, VMBO zorg en welzijn of $M B O$ techniek. Door omscholing naar fysiek minder belastende functies zouden deze groepen werkenden het risico op verlies van werk kunnen beperken, wanneer men op een bepaald moment niet meer in staat zou blijken de huidige functie uit te oefenen.

Psychische belasting door een hoge tijdsdruk is met name een risico voor werkenden in de kwartaire diensten, transport en communicatie en metaal-en elektrotechniek. Het feit dat werkenden binnen deze sectoren nog relatief weinig aan scholing doen en hun functionele flexibiliteit bovendien achterblijft bij het gemiddelde maakt dat werkenden in deze sectoren het meest in aanmerking komen voor scholings- en, wat breder geformuleerd, employabilitybeleid. Vooral managers met een wetenschappelijk werk- en denkniveau en werkenden in de bogere tecbnische en middelbare (para)medische beroepen hebben met een hoge tijdsdruk te maken. Voor deze laatste categorie is extra aandacht nodig, omdat in deze beroepen de scholingsdeelname relatief gering is. Om hun waarde te behouden op de arbeidsmarkt zal scholing en meer functionele flexibiliteit nodig zijn. Overigens zijn het vooral hoger opgeleiden (WO techniek, WO sociaal cultureel of WO letteren en theologie) die aangeven onder hoge tijdsdruk te werken. Het is mogelijk dat de hoge tijdsdruk er juist de reden van is dat de hier genoemde groepen werkenden weinig aan scholing deelnemen. Cursussen op het gebied van time-management en iets meer afwisseling in het werk zouden de psychische belasting kunnen heperken, zodat het verlies van werk als gevolg van stress en oververmoeidheid kan worden voorkomen. Er zal in eerste instantie dan ook meer tijd vrij gemaakt moeten worden voor scholing en flexibilisering.

In de sectoren overige industrie en kwartaire diensten wordt nog te weinig aan scholing deelgenomen en zijn werkenden waarschijnlijk niet voldoende functioneel flexibel om het hoofd te kunnen bieden aan de snelle technologische en organisatorische ontwikkelingen. 
In de sectoren overbeid en onderwijs, energie en bank-verzekeringswezen is enkel de functionele flexibiliteit mogelijk te gering om de ontwikkelingen te volgen. Wat betreft de scholingsdeelname scoren deze sectoren wel relatief gunstig. Vooral werkenden in middelbare (para)medische en middelbare juridische, bestuurlijke beveiligingsberoepen behoren tot de doelgroepen voor scholingsbeleid en beleid gericht op functionele flexibiliteit.

In de bedrijfssectoren metaal-en elektrotechniek en bouw en onroerend goed vormt de werkgelegenheidskrimp een belangrijke risicofactor, temeer daar de scholingsdeelname en de functionele flexibiliteit van de werkenden in deze sectoren relatief gering is. Met name voor werkenden in de lagere en middelbare technische beroepen wordt de komende jaren een relatief hoge baanvernietiging verwacht. Gezien de beperkte scholingsdeelname en de geringe functionele flexibiliteit van de werkenden in deze beroepen worden lagere, middelbare technici daarom tot de doelgroepen voor scholingsbeleid gerekend.

Voor werkenden met een opleiding VMBO landbouw en natuurlijke omgeving of alleen basisonderwijs wordt de grootste baanvernietiging verwacht. In combinatie met de lage scholingsdeelname en de geringe functionele flexibiliteit van de werkenden met een van deze opleidingsachtergronden leidt dit tot een verhoogd risico op verlies van werk. Werkenden met een opleiding VMBO landbouw en natuurlijke omgeving of basisonderwijs behoren om deze reden eveneens tot de potentiële doelgroepen voor het scholingsbeleid gericht op het voorkomen van verlies van werk door kwalificatieveroudering.

\section{Kansrijke scholingstrajecten}

Voor de potentiële doelgroepen die gedwongen zijn zich om te scholen voor ander werk is nagegaan welke scholingsactiviteiten een beter perspectief bieden op behoud van werk. Een dergelijke omscholing is noodzakelijk wanneer werkenden hun baan verliezen vanwege de afnemende werkgelegenheid of de sterke reallocatie van de werkgelegenheid op het arbeidsmarktsegment waarin zij zich bevinden. Daarnaast kan omscholing noodzakelijk zijn wanneer werkenden vanwege de fysiek belastende arbeidsomstandigheden op een bepaald moment hun huidige functie niet meer kunnen uitoefenen.

Voor een aantal beroepen met een hoog risico op verlies van werk zijn er in principe uitwijkberoepen met goede arbeidsmarktperspectieven. Zo zouden werkenden die hun werk dreigen te verliezen in de elementaire, lagere technische en lagere verzorgende beroepen zich kunnen laten omscholen tot verkopers. De werkenden in de elementaire beroepen zouden bovendien na een omscholingstraject aan de slag kunnen als receptionist(e) en administratief employe(e).

Voor werkenden in de middelbare verzorgende beroepen is er geen enkel verwant beroep dat gekenmerkt wordt door gunstige arbeidsmarktperspectieven. De werkenden in deze beroepssegmenten zullen daardoor gedwongen zijn zich om te scholen naar beroepen die niet direct verwant zijn aan hun huidige beroep. 
Werknemers met alleen basisonderwijs zijn doorgaans het meest gebaat bij substantiële bijscholing voor het behoud van hun huidige baan, waarvoor steeds hogere kwalificaties worden gevraagd, meestal op het niveau van 'basisberoepsbeoefenaar'. Voor werkenden met een opleiding VMBO zorg en welzijn of VMBO techniek zijn geen verwante opleidingen met goede perspectieven voorhanden, wat inhoudt dat deze groepen werkenden uit zullen moeten wijken naar een niet aan hun huidige opleidingsachtergrond verwante opleiding met een beter arbeidsmarktperspectief. Werkenden met een opleiding VMBO landbouw en natuurlijke omgeving die het risico lopen hun werk te verliezen doordat hun opleidingsniveau niet langer toereikend is om adequaat hun functie te vervullen kunnen zich laten 'opscholen' tot het niveau van MBO landbouw en veeteelt. Een soortgelijke niveauverhogende opleiding staat voor werkenden met een opleiding $M B O$ techniek open. Door het volgen van een verwante technische opleiding op $\mathrm{HBO}-$ niveau, bijvoorbeeld HBO civiele techniek, kunnen zij hun perspectieven op de arbeidsmarkt aanzienlijk verbeteren.

\section{Het werkgelegenheid en scholing observatorium 1996-1999}

De herziening van de Europese structuurfondsen voor de nieuwe planperiode 20002007 plaatst de scholing van werkenden in het bredere kader van het nieuwe ESF-3.

In het kader van de Europese werkgelegenheidsstrategie waarop de herziening mede is gestoeld, komt de bij- of omscholing van werkenden en werkzoekenden als een van de belangrijkste thema's naar voren, met name ook voor Nederland. In het Nationale Actieplan Werkgelegenbeid wordt dan ook gepleit voor continue aandacht voor bij- en omscholing ter voorkoming van veroudering van kennis en vaardigheden. De monitoring van de risico's op kwalificatieveroudering, de ontwikkeling van competenties en de loopbaanontwikkeling van werkenden, werklozen en niet-participerenden, die mogelijk willen herintreden, kan een belangrijke preventieve rol vervullen bij het voorkomen van verlies van werk. De monitoring levert een richtinggevend kader voor het verstrekken van scholingssubsidies, doordat wordt aangegeven welke arbeidskrachten een bepaald risico lopen op kwalificatieveroudering waardoor ze hun werk kunnen verliezen en moeilijk ander werk kunnen verrichten. Dit omdat er te weinig aandacht is voor scholing en de employability van deze werknemers. Bovendien kan continue monitoring bedrijven en werkenden helpen bij de bewustwording van risico's op kwalificatieveroudering die voor hen van belang zijn. Deze bewustwording staat aan de basis van de invoering van beleidsinstrumenten gericht op employability in de vorm van functionele flexibiliteit en scholing. Wanneer de monitoring zoals die tot nu toe heeft platsgehad een bencbmark functie zou gaan vervullen wordt deze aanjagende functie nog versterkt.

Met de in het eerste themarapport in het kader van het WSO-programma van 1998 gecreëerde Sectorale Employability Index is een eerste stap gezet in de richting van een employability-benchmark. Het Ministerie van Sociale Zaken en Werkgelegenheid heeft recentelijk het vootouw genomen voor het opzetten van een Employability Monitor: Deze monitor zal zich niet alleen richten op het in kaart brengen van de employability van de werkenden, mar ook inzicht moeten geven in de employability van de werkloze beroepsbevolking en de mensen die niet participeren op de arbeidsmarkt. 
De herziening van de Europese structuurfondsen in de nieuwe planperiode 2000- 2007 plaatst, zoals gezegd, de scholing van werkenden in het bredere kader van het nieuwe ESF-3. Daarbij wordt ook een expliciet verband gelegd met de Europese Werkgelegenheidsstrategie, zoals die tot uiting moet komen in de Nationale Actieplannen Werkgelegenheid. In Nederland zullen er daarbij twee nationale prioriteiten centraal staan:

- Een Activerend arbeidsmarktbeleid gericht op (1) het bestrijden en voorkomen van langdurige werkloosheid en (2) de scholing van werkenden.

- Een Leven Lang Leren gericht op de bestrijding van voortijdig schoolverlaten, het versterken van de beroepsbegeleidende leerweg en het praktijk onderwijs.

Het Nationale Actieplan Werkgelegenheid integreert in het kader van het Activerend arbeidsmarktbeleid het scholingsbeleid gericht op (langdurig) werklozen met de scholing van werkenden. Het scholingsbeleid staat bovendien niet langer alleen in het teken van een saciaal beleid ten behoeve van mensen met een zwakkere arbeidsmarktpositie, maar is tevens gericht op de problematiek die zich steeds sterker aan de vraagzijde van de arbeidsmarkt aftekent. Gezien de grote knelpunten in de personeelsvoorziening waarmee werkgevers worden geconfronteerd, is het van groot maatschappelijk belang te voorkomen dat er mensen aan de zijlijn blijven of komen te staan, omdat hun kwalificaties niet (langer) toereikend zijn voor de openstaande functies. De scholing van mensen na het verlaten van het initiëel onderwijs speelt daarbij een cruciale rol. Enerzijds is er ten aanzien van de scholing van werklozen en werkzoekenden een 'curatieve' inhaalslag vereist die mensen in staat stelt werk te krijgen of hun werk te behouden. Anderzijds zal door de voortschrijdende 'vergrijzing' van de beroepsbevolking en de snelle technologische ontwikkelingen - in het kader van een 'preventief beleid - het voorkomen van kwalificatieveroudering door bij- en omscholing de komende jaren de permanente aandacht vragen.

De monitoring van de verschillende risico's op kwalificatieveroudering en de ontwikkeling van competenties van werkenden, werklozen en niet-participerenden kan in het kader van het Nationale Actieplan Werkgelegenheid een zeer waardevolle rol spelen. In de eerste plaats biedt een monitoring de mogelijkheid te anticiperen op de verwachte ontwikkelingen op de arbeidsmarkt en de te verwachten gevolgen van de gesignaleerde risico-factoren in een bepaalde sector, beroepsgroep of voor mensen met een bepaalde opleidingsachtergrond. Daarbij kan in het bijzonder in het oog gehouden worden op welke punten er vanuit maatschappelijk oogpunt sprake is van marktfalen vanwege het ontbreken van de juiste 'incentives' bij werkgevers of de werkenden zelf. Op deze manier ontstaat er ook een richtinggevend kader voor het eventueel verstrekken van scholingssubsidies ter voorkoming van werkloosheid of vroegtijdige uittrede uit de arbeidsmarkt. 


\section{Inleiding}

\section{Probleemstelling}

Kennis en vaardigheden van werkenden moeten voortdurend worden aangepast aan de veranderende eisen die de arbeidsmarkt stelt. Om zeer uiteenlopende redenen kunnen werkenden te kampen hebben met veroudering van hun kennis en vaardigheden. Deze veroudering van kwalificaties leidt er toe dat werknemers op een bepaald moment in de problemen komen voor wat betreft hun positie op de arbeidsmarkt; zij lopen het risico hun werk te verliezen.

Gerichte scholingsactiviteiten kunnen dit wellicht voorkomen of verhelpen. Bij een adequaat scholingsbeleid dient de 'employability' van werkenden centraal te staan. Daarbij gaat het om het versterken van de positie van werkenden op de arbeidsmarkt. Deze versterking van de arbeidsmarktpositie moet ertoe leiden dat werkenden enerzijds beter in staat zijn hun baan te behouden en anderzijds gemakkelijker een andere baan kunnen vinden. Om een dergelijk scholingsbeleid te kunnen voeren moet een antwoord worden gegeven op een tweetal centrale vragen:

1. Welke groepen werkenden lopen een verhoogd risico op verlies van werk als gevolg van kwalificatieveroudering?

2. Welke scholings- c.q. ontwikkelingsactiviteiten bieden deze groepen de beste mogelijkheden om aan het werk te blijven?

Deze twee vragen staan centraal binnen het Werkgelegenheid en Scholing Observatorium (WSO). In de eerste rapportage Werkgelegenheid en scholing 1996 werd vooral aandacht geschonken aan de risico's op verlies van werk als gevolg van technologische ontwikkelingen of een krimpende werkgelegenheid in bepaalde segmenten van de arbeidsmarkt. Met name de automatisering en informatisering van veel productieprocessen kwamen daarbij naar voren als belangrijke risico-factoren. In de tweede rapportage, Werkgelegenbeid en scholing 1997, werden fysiek en psychisch belastende arbeidsomstandigheden hieraan toegevoegd als belangrijke oorzaken voor verlies van kwalificaties. Doordat werkenden bij voortduring worden blootgesteld aan belastende arbeidsomstandigheden lopen zij een verhoogd risico hun functie op een gegeven moment niet meer uit te kunnen oefenen. De kwalificaties waarover zij beschikken zullen daardoor in belangrijke mate hun waarde verliezen.

Daarnaast werd het scholingsbeleid gericht op het behoud van werk in het bredere perspectief geplaatst van de 'employability' van werkenden als remedie tegen verlies van werk als gevolg van kwalificatieveroudering. Hiertoe zijn naast de scholingsinspanningen van werkenden ook factoren als inzetbereidheid en mobiliteitsbereidheid in beeld gebracht. In 1998 ziin enkele centrale thema's binnen het WSO in een drietal specifieke rapportages verder uitgediept.

In Employability in bedrijf: Naar een Employability Index voor Bedrijfssectoren (De Grip c.s., 1998) staat de ontwikkeling van de sectorale employability-index (SEI) centraal, een index die aangeeft hoe sectoren er in een onderlinge vergelijking voorstaan 
wat betreft employability. Het tweede deelrapport, Scholing van werkenden (De Grip c.s., 1999), heeft beoogd enkele van de centrale veronderstellingen uit het WSO-model te onderzoeken. In het derde deelrapport Organisatieveranderingen en competentieontwikkeling (Borghans c.s., 2000) wordt verslag gedaan van een onderzoek naar de herkomst en opbouw van competenties bij werknemers. Tevens wordt hierbij studie verricht naar de rol die organisatieveranderingen spelen bij de (her)waardering van aanwezige competenties. Waar mogelijk worden de uitkomsten van deze studie gebruikt ter verheldering van de in dit rapport gevonden resultaten. Het positioneren van het scholingsbeleid gericht op behoud van werk in het bredere kader van de 'employability' van werkenden vergroot ook het perspectief van waaruit een dergelijk scholingsbeleid dient te worden gevoerd. Bij de scholing voor behoud van werk stond traditioneel het belang van werkenden met een zwakke arbeidsmarktpositie centraal. De sterk verkrappende arbeidsmarkt in de tweede helft van de jaren negentig maakt duidelijk dat het 'employable' houden van werkenden die het risico lopen te worden geconfronteerd met kwalificatieveroudering ook voor werkgevers van groot belang is. Werkgevers ondervinden als gevolg van de krapte immers steeds meer problemen bij de werving en selectie van personeel. Uit een studie van Borghans c.s. (1998) komt naar voren dat het beperken van de arbeidsmarktuitstroom van werkenden voor de komende jaren het belangrijkste middel is bij het verminderen van de knelpunten in de personeelsvoorziening op de verschillende segmenten van de arbeidsmarkt.

In dit derde overzichtsrapport zal opnieuw een integraal en actueel overzicht worden gegeven van de verschillende oorzaken van kwalificatieveroudering en de mate waarin werkenden met die oorzaken worden geconfronteerd. Daarbij gaat het om ontwikkelingen op het gebied van arbeidsomstandigheden, technologie, organisatie van het werk, informatisering, werkgelegenheid, scholing en functionele flexibiliteit. Allemaal ontwikkelingen die een vorm van kwalificatieveroudering tot gevolg kunnen hebben en dus een verhoogd risico op verlies van werk met zich mee kunnen brengen voor bepaalde groepen werkenden.

Wederom zal voor de belangrijkste risicogroepen worden aangegeven wat voor hen de meest kansrijke scholingstrajecten zijn om zich op de arbeidsmarkt te handhaven. Om de risicogroepen te kunnen onderscheiden zal net als in voorgaande jaren worden verbijzonderd naar bedrijfssector, beroep en opleidingsachtergrond. Waar mogelijk wordt eveneens een onderscheid gemaakt tussen het midden- en kleinbedrijf en de grotere ondernemingen. Meer dan in de vorige rapporten het geval was zal ter illustratie en ondersteuning van gevonden ontwikkelingen gebruik worden gemaakt van de beschikbare kwalitatieve informatie, aangevuld met een aantal interviews met sleutelpersonen.

\section{Concepten en definities}

Investeringen in scholing kunnen om verschillende redenen plaatsvinden. Analoog aan investeringen in fysiek kapitaal zou ook voor menselijk kapitaal een onderscheid gemaakt kunnen worden in uitbreidingsinvesteringen en vervangingsinvesteringen. Bij uitbreidingsinvesteringen wordt nieuw menselijk kapitaal verworven. Het investeren in initieel onderwijs is bijvoorbeeld een uitbreidingsinvestering. Ook het verwerven van nieuwe kwalificaties ten behoeve van de uitoefening van een nieuwe functie en/ of een nieuw beroep kan worden gezien als een uitbreidingsinvestering. 
Vervangingsinvesteringen zijn daarentegen gerelateerd aan de waardevermindering van bestaand menselijk kapitaal vanwege kwalificatieveroudering. Het niet vervangen van verouderde kwalificaties door nieuwe kwalificaties kan de werkgelegenheid voor bepaalde groepen werkenden in gevaar brengen. Onder vervangingsinvesteringen verstaan we dus de investeringen ten behoeve van het bijspijkeren en up-to-date houden van het aanwezige menselijk kapitaal.

De veroudering van de kwalificaties van werkenden, ofwel de devaluatie van menselijk kapitaal, kan op verschillende manieren plaatsvinden (zie tabel 1.1). In de eerste plaats kan er sprake zijn van slijtage. Slijtage kan worden gedefinieerd als de afschrijving van menselijk kapitaal door het natuurlijk ouderwordingsproces, ziekte of letsel. Volgens Neuman en Weiss (1995) is slijtage een vorm van technische kwalificatieveroudering. Zij spreken zelf van 'internal depreciation of human capital' omdat het gaat om een vorm van waardevermindering die toe te schrijven is aan de werknemer zelf en die zich uit in het verlies van zowel fysieke als mentale capaciteiten. Slijtage leidt er in veel gevallen toe dat werkenden bepaalde onderdelen van hun oorspronkelijke functie niet langer uit kunnen oefenen. Doordat zij daardoor minder goed inzetbaar zijn verzwakt hun arbeidsmarktpositie en neemt het risico van verlies van werk toe.

Uit het themarapport Scholing van werkenden (De Grip c.s., 1999) komt naar voren dat de oorzaken van slijtage voornamelijk liggen in belastende arbeidsomstandigheden als lawaai, stank, geestelijk zwaar werk en herhaalde eenvoudige werkzaamheden. Een hogere leeftijd blijkt daarbij als risicoverhogende factor te gelden. Belastende arbeidsomstandigheden hebben naast slijtage ook andere belangrijke gevolgen voor bedrijven, zoals negatieve productiviteitseffecten, kosten van ziekteverzuim en arbeidsongeschiktheid, ontslagkosten en kosten voor werving en training van nieuwkomers. Het voorkomen van belastende arbeidsomstandigheden lijkt dus zeer de moeite waard, zeker op een arbeidsmarkt zo krap als de huidige. Scholing en employability zouden daarbij van belang kunnen zijn als het gaat om gerichte training in het verantwoord gebruik van computerapparatuur of gereedschappen en om adequate voorlichting omtrent het voorkomen van werkgerelateerde ziekteverschijnselen zoals RSI.

Daarnaast kunnen bijvoorbeeld ook taakroulatie en regelmatige functieverandering bepaalde ziekteverschijnselen voorkomen.

Een tweede vorm van technische kwalificatieveroudering is atrofie (De Grip c.s., 1990). Atrofie doet zich voor wanneer werkenden bepaalde kwalificaties gedurende langere tijd niet of onvoldoende gebruiken. Atrofie komt bijvoorbeeld voor wanneer werkenden zich tijdelijk terugtrekken van de arbeidsmarkt voor de verzorging van hun kinderen of om andere redenen. Ook wanneer werkenden zich gaan specialiseren op een bepaald gebied kan atrofie zich voordoen. Door deze specialisatie wordt nog slechts een deel van de aanwezige kwalificaties aangewend en verder ontwikkeld en verouderen de overige. In navolging van Thijssen (1996) wordt dit wel aangeduid als ervaringsconcentratie.

Behalve deze twee vormen van technische kwalificatieveroudering worden drie vormen van economische kwalificatieveroudering onderscheiden. Bij economische kwalificatieveroudering gaat het niet zozeer om veranderingen bij de werknemers zelf, maar om een waardedaling van het menselijk kapitaal als gevolg van veranderingen van buitenaf. 
Neuman en Weiss spreken hier dan ook van 'external depreciation of human capital'. Aan economische kwalificatieveroudering kan een scala van technologische, organisatorische en arbeidsmarktontwikkelingen ten grondslag liggen. In de eerste plaats kunnen de kwalificatievereisten voor bepaalde functies veranderen, bijvoorbeeld als gevolg van het in gebruik nemen van nieuwe technologieën, waardoor bestaande kennis en vaardigheden niet langer toereikend zijn voor een adequate functievervulling (zie ook Pillay, 1998 en Watkins en Marsick, 1993). Deze vorm van economische kwalificatieveroudering kan worden aangeduid als functie-inboudelijke kwalificatieveroudering.

Een personeelsfunctionaris die wordt geconfronteerd met een nieuwe arbeidswetgeving of een nieuw geautomatiseerd personeelsinformatiesysteem heeft bijvoorbeeld te maken met deze vorm van kwalificatieveroudering. Het veranderen van de kwalificatievereisten kan er in enkele gevallen zelfs toe leiden dat werkgevers naar andere opleidingsrichtingen gaan vragen dan in het verleden. In de meeste gevallen zal er dan sprake zijn van een 'upgrading' van functies waardoor een hoger opleidingsniveau vereist wordt. Werknemers die niet kunnen voldoen aan de hogere eisen hebben te maken met functie-inhoudelijke kwalificatieveroudering, die, naarmate de discrepantie tussen het vereiste kwalificatieniveau en het aanwezige kwalificatieniveau groter is en sneller groeit, ernstiger vormen aanneemt.

In Scholing van werkenden (De Grip c.s., 1999) is onderzocht in hoeverre de kans dat een opleiding is verouderd toeneemt als gevolg van veranderingen in de te verrichten werkzaamheden. Uit dit onderzoek blijkt dat vooral ontwikkelingen op het gebied van de informatietechnologie en ontwikkelingen op organisatorisch vlak de kans op functie-inhoudelijke kwalificatieveroudering vergroten.

Een tweede mogelijkheid is dat de kennis en vaardigheden van werkenden voor hun huidige functie nog wel afdoende zijn, maar dat de vraag naar deze functies afneemt. Dit kan worden aangeduid als kwalificatieveroudering door marktontwikkelingen. De werkgelegenheid in een bepaalde bedrijfssector kan krimpen (bijvoorbeeld in de landbouw), bepaalde beroepen kunnen in verschillende bedrijfssectoren al dan niet als gevolg van upgrading te kampen hebben met een krimpende werkgelegenheid (bijvoorbeeld de lagere administratieve beroepen). Het werkgelegenheidsaandeel van een bepaald beroep in een bepaalde bedrijfssector kan afnemen (bijvoorbeeld de middelbaar commerciële beroepen in het bank- en verzekeringswezen). Een aantal werkenden zal daardoor worden gedwongen uit te wijken naar een ander beroep en/of een andere bedrijfssector:

Ook kan het voorkomen dat een werkende van bedrijf dient te veranderen, als gevolg van overtolligheid door ontwikkelingen op bedrijfsniveau. Reorganisaties en afstotingen kunnen bijvoorbeeld ontslagen met zich mee brengen. Zo'n verandering van bedrijf gaat gepaard met bedriffspecifieke kwalificatieveroudering. Bij deze vorm van kwalificatieveroudering gaat dat deel van het menselijk kapitaal verloren dat bedrijfsspecifiek is, bijvoorbeeld kennis van bepaalde specifieke apparatuur, procedures of reglementen.

Kwalificatieveroudering kan een risico impliceren van het geheel of gedeeltelijk verliezen van werk. Bij een lagere productiviteit zal de arbeidsmarktpositie van de werknemer immers worden aangetast. In principe kan hier op twee manieren op worden gere- 
ageerd: de beloning kan worden verlaagd of de productiviteit zal moeten worden verhoogd. Primair uitgangspunt in dit rapport is het verhogen van de productiviteit van de werknemer door middel van scholing gericht op behoud van werk.

Het spreekt voor zich dat kwalificatieveroudering niet bij elke arbeidskracht tot hetzelfde risico van verlies van werk leidt. Werknemers die bijvoorbeeld met een vaste aanstelling werkzaam zijn in een goed renderend bedrijf zullen doorgaans een kleinere kans hebben door kwalificatieveroudering hun werk te verliezen dan tijdelijke krachten in een noodlijdende onderneming. Niet in het minst omdat goed draaiende bedrijven over het algemeen meer investeren in het menselijk kapitaal van het personeel, waardoor kwalificatieveroudering wordt tegengegaan. Noodlijdende ondernemingen hebben voor dergelijke investeringen vaak geen ruimte en als die ruimte er wel is wordt met name geinvesteerd in vaste krachten. Het risico van verlies van werk is met name groot in een situatie waarin naar nieuw werk gezocht moet worden. Heeft een werkzoekende verouderde kwalificaties dan is diens arbeidsmarktpositie zwak. Dat geldt overigens ook voor een werkzoekende die een zeer bedrijfsspecifiek kwalificatiepakket heeft. Bedrijfsspecifieke kwalificaties verliezen immers veel, zo niet alle, waarde bij de overstap naar een ander bedrijf.

Tabel 1.1

Vormen en oorzaken van kwalificatieveroudering, risico-verhogende factoren en mogelijke remedies

\begin{tabular}{|c|c|c|c|c|}
\hline $\begin{array}{l}\text { Vorm van } \\
\text { kwalificatie- } \\
\text { veroudering }\end{array}$ & $\begin{array}{l}\text { Afschrijving } \\
\text { menselijk } \\
\text { kapitaal door: }\end{array}$ & $\begin{array}{l}\text { Specifieke } \\
\text { oorzaken }\end{array}$ & $\begin{array}{l}\text { Risico } \\
\text { verhogende } \\
\text { factoren }\end{array}$ & $\begin{array}{l}\text { Mogelijke } \\
\text { remedies }\end{array}$ \\
\hline Slijtage & $\begin{array}{l}\text { Natuurlijk ouder- } \\
\text { wordingsproces, } \\
\text { ziekte of letsel }\end{array}$ & $\begin{array}{l}\text { Stank, lawaai } \\
\text { Trilling } \\
\text { Kracht zetten } \\
\text { Tijdsdruk } \\
\text { Ploegendienst } \\
\text { RSI }\end{array}$ & Hoge Leeftijd & Her- of omscholing \\
\hline Atrofie & $\begin{array}{l}\text { Niet of onvoldoende } \\
\text { gebruik van } \\
\text { kwalificaties }\end{array}$ & $\begin{array}{l}\text { Vergaande } \\
\text { specialisatie }\end{array}$ & & Herscholing \\
\hline Functie-inhoudelijk & $\begin{array}{l}\text { Nieuwe kwalificatie- } \\
\text { vereisten voor de } \\
\text { functie }\end{array}$ & $\begin{array}{l}\text { Informatisering, } \\
\text { product- of proces- } \\
\text { vernieuwing } \\
\text { Organisatorische } \\
\text { ontwikkelingen } \\
\text { (reorganisaties e.d.) }\end{array}$ & Hoge leeftijd & $\begin{array}{l}\text { (Substantiële) } \\
\text { bijscholing }\end{array}$ \\
\hline Marktontwikkelingen & $\begin{array}{l}\text { Krimpende werk- } \\
\text { gelegenheid in } \\
\text { bepaald beroep } \\
\text { of bedriifssector }\end{array}$ & $\begin{array}{l}\text { Vereiste verandering } \\
\text { van beroep en/of } \\
\text { bedrijfssector }\end{array}$ & $\begin{array}{l}\text { Flexibel contract } \\
\text { Hoge leeftijd } \\
\text { Lange verblififsduur }\end{array}$ & $\begin{array}{l}\text { Omscholing } \\
\text { Bijscholing } \\
\text { (als beroep } \\
\text { gelijk blift) }\end{array}$ \\
\hline Bedrijfsspecifiek & $\begin{array}{l}\text { Bedriffssluiting } \\
\text { of reorganisatie }\end{array}$ & $\begin{array}{l}\text { Vereiste verandering } \\
\text { van bedrijf }\end{array}$ & $\begin{array}{l}\text { Lang dienstverband } \\
\text { en aantal specifieke } \\
\text { cursussen }\end{array}$ & Omscholing \\
\hline
\end{tabular}


In tabel 1.1 wordt een volledig overzicht gegeven van de vijf verschillende vormen van kwalificatieveroudering. Tevens is aangegeven welke factoren het risico van veroudering van kwalificaties versterken en wat de eventuele remedie is om het kwalificatieverlies tegen te gaan.

In het geval van waardevermindering van menselijk kapitaal als gevolg van slijtage zou aanpassing van de werkplek preventief kunnen werken. Wanneer er echter al sprake is van onherstelbare gezondheidsschade dan staat alleen de omscholingsweg nog open om een volledig verlies van werk te voorkomen. Omscholing is het verkrijgen van kwalificaties die vereist zijn voor een ander beroep of werk in een andere bedrijfssector. Omscholing is ook noodzakelijk indien er sprake is van kwalificatieveroudering door marktontwikkelingen. Als iemand bij een krimpende werkgelegenheid zijn of haar baan verliest, zullen de kansen om weer werk te vinden in een soortgelijke functie gering zijn. Naar de kwalificaties waarover men beschikt is immers geen vraag meer. Men zal zich dus andere kwalificaties eigen moeten maken om aan het werk te kunnen blijven.

Wanneer de waardevermindering van kwalificaties het gevolg is van het tijdelijk niet of te weinig gebruiken van reeds opgedane kennis en vaardigheden (atrofie) dan is herscholing een goede remedie. Herscholing wordt gedefinieerd als het opfrissen van kennis of vaardigheden die een individu reeds eerder heeft bezeten. Herscholing is weliswaar met name een remedie tegen atrofie, maar het kan ook een hulpmiddel zijn in gevallen warin werknemers als gevolg van het natuurlijke verouderingsproces dingen gaan vergeten. Dit zou mentale slijtage kunnen worden genoemd. Is er sprake van fysieke slijtage dan ligt omscholing meer voor de hand.

Een derde remedie is bijscholing. Bij bijscholing gaat het om het uitbouwen van bestaande kennis of vaardigheden ten behoeve van de huidige of een soortgelijke functie. Wanneer er sprake is van upgrading van het vereiste opleidingsniveau voor een functie, waardoor bijvoorbeeld een VMBO opleidingsachtergrond voor deze functie niet langer voldoet, maar minstens MBO niveau wordt vereist, is zelfs substantiële bijscholing nat een hoger opleidingsniveau nodig om de functie die men uitoefent adequaat te kunnen blijven vervullen. Recentelijk zijn dergelijke substantiële bijscholingsprogramma's onder anderen bij Rabobank Nederland en KPN Telecom in gang gezet. Rabobank Nederland beoogt de werkenden met opleidingen op VMBO niveau of lager (zo'n vierduizend werknemers) bij te scholen tot MBO niveau (Dikker, 1997). KPN Telecom beoogt door middel van MBO trajecten zo'n 2.200 medewerkers bij te scholen.

De intensiteit en dur van het scholingstraject dat voor bepaalde groepen werkenden de beste arbeidsmarktperspectieven biedt, is afhankelijk van de verwantschap tussen de kwalificaties waarover iemand beschikt en de voor het behoud van werk vereiste kwalificaties. Hoe groter de verwantschap tussen deze kwalificaties des te lager de kosten van het scholingstraject en des te groter de kans op succes. Het ligt natuurlijk voor de hand dat het wat meer geld en moeite zal kosten om een ongeschoolde metaalarbeider tor leerkracht in het basisonderwijs om te scholen dan om de betrokkene bijvoorbeeld om te scholen to bankwerker of magazijnmedewerker. Het is overigens niet zo dat wanneer iemand een opleiding op een bepaald niveau heeft gevolgd, dit automatisch wil zeggen dat de meeste beroepen op dat niveau kunnen worden uitgeoefend met een beperkte scholingsinspanning. Een banketbakker zal bijvoorbceld meer noeite hebben 
zich te laten omscholen tot dakdekker dan een metselaar. De mate van verwantschap kent dus meerdere dimensies: zowel iemands opleidingsniveau als de gevolgde opleidingsrichting spelen daarbij een belangrijke rol.

\section{Opzet rapport}

Figuur 1.1 geeft een overzicht van het kader van waaruit het WSO beoggt in dit rapport op systematische wijze informatie te genereren om de twee eerder genoemde centrale vraagstellingen te kunnen beantwoorden.

Figuur 1.1

\section{Overzicht globale opzet rapport}

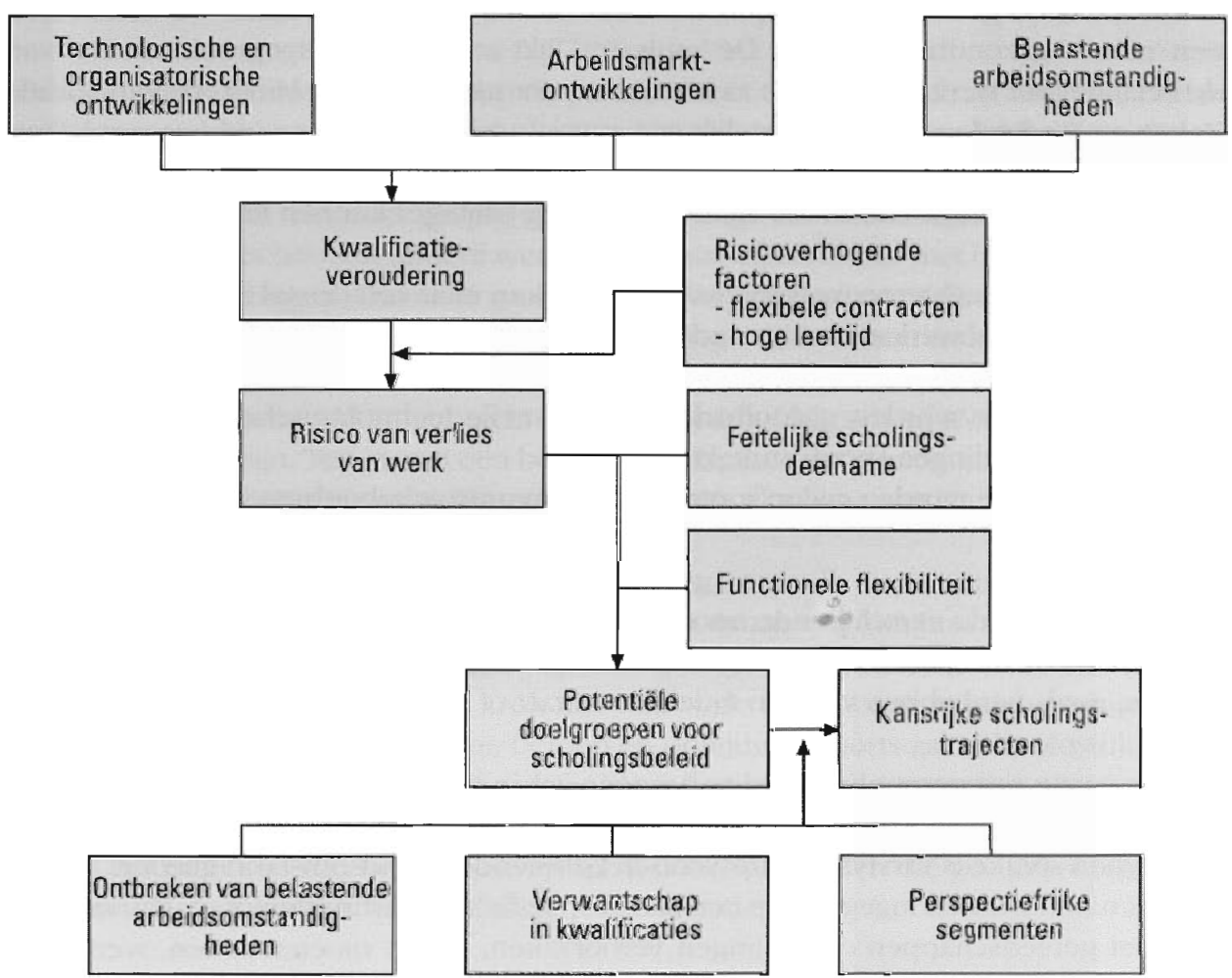

Zoals reeds is aangegeven, kan kwalificatieveroudering veroorzaakt worden door een samenspel van organisatorische, technologische en arbeidsmarktontwikkelingen. Daarnaast is gebleken dat ook de omstandigheden waaronder werkenden hun arbeid verrichten een veroudering van kwalificaties tot gevolg kunnen hebben. Evenals in de vorige rapportage, Werkgelegenbeid en scholing 1997, zal zowel aan econonische kwalificatieveroudering vanwege technologische en arbeidsmarktontwikkelingen als an technische kwalificatieveroudering vanwege psychisch en/of fysiek belastende arbeidsomstandigheden aandacht worden geschonken. Overigens kunnen de verschillende oorzaken van zowel economische als technische kwalificatieveroudering niet altijd los van elkaar worden gezien. De komst van bijvoorbeeld nieuwe machines, softwarepak- 
ketten of andere technologische vernieuwingen zorgt er enerzijds voor dat kwalificaties steeds sneller verouderen, waardoor de arbeidsmarktpositie van bepaalde groepen werkenden wordt aangetast en het risico van verlies van werk voor deze groepen wordt vergroot. Anderzijds kunnen technologische ontwikkelingen bijdragen aan het krimpen van de werkgelegenheid in sommige bedrijfssectoren of beroepen, doordat eenvoudig handmatig werk over wordt genomen door computers. Computers en scanners hebben de functie van datatypiste bijvoorbeeld vrijwel doen verdwijnen en de komst van gelden wisselautomaten heeft de kassierfuncties in het bankwezen ingrijpend veranderd. Deze ontwikkelingen op technologisch gebied zijn ook verwerkt in de prognoses van de veranderingen in de opleidingen-, beroepen- en sectorenstructuur van de werkgelegenheid, die in hoofdstuk 4 aan de orde komen.

Het toenemend gebruik van computers, zowel thuis als op het werk, leidt bovendien tot cen 'nieuw' gezondheidsrisico's. De 'muisarm' lijkt zelfs te zijn uitgegroeid tot één van de belangrijkste werkgerelateerde ziektes. Niet voor niets heeft het Ministerie van Sociale Zaken en Werkgelegenheid recentelijk een speciale internetsite geopend genaamd 'Stop RSI'. Reden genoeg om aan te nemen dat ontwikkelingen op informatietechnologisch gebied ook tot technische kwalificatieveroudering (slijtage) kunnen leiden.

In dit rapport zal achtereenvolgens worden gekeken naar een drietal risicogroepen

- werkenden die werkzaam zijn onder fysiek en/of psychisch belastende arbeidsomstandigheden (hoofdstuk 2);

- werkenden die worden geconfronteerd met snelle technologische en organisatori sche ontwikkelingen (hoofdstuk 3);

- werkenden die worden geconfronteerd met ongunstige arbeidsmarktontwikkelingen (hoofdstuk 4).

Daarnaast zal in de verschillencle hoofdstukken aandacht worden geschonken aan die factoren die het risico van verlies van werk als gevolg van kwalificatieveroudering versterken, zoals het hebben van een tijdelijk contract of een gevorderde leeftijd.

On de eerste risicogroep in beeld te brengen zal in hoofdstuk 2 een indicatie worden gegeven van de mate waarin er in de verschillende bedrijfssectoren, beroepen en opleidingstypen sprake is van fysiek of psychisch belastende arbeidsomstandigheden. Hierbij zal met name worden ingegaan op een aantal specifieke belastingsfactoren: lawaai, werken met gereedschappen die trillingen veroorzaken, kracht moeten zetten, werken in ploegendienst en werken onder tijdsdruk. Daarnaast zal meer specifiek worden ingegatan op de RSI-problematiek.

Daama zal in hoofdstuk 3 de tweede risicogroep worden getraceerd door het in kaart brengen van de diffusie van technologische en organisatorische vernieuwingen in de verschillende bedriffssectoren, beroepen en opleidingen. Dit zal gebeuren aan de hand van een drietal centrale indicatoren: een ICT-index, die de ontwikkelingen op het gebied van automatisering en bijvoorbeeld het bedrijfsmatige gebruik van internet indiceert; een R\&D-index, die de ontwikkelingen op het gebied van R\&D indiceert en een Organisatorische veranderingen index, die beoogt een beeld te schetsen van ontwikkelingen op het gebied van reorganisaties en veranderingen in productpakketten en productieprocessen van bedrijven. Het samenvoegen van deze drie indices levert een index 
die technologische en organisatorische ontwikkelingen in beeld brengt. Deze index kan alleen worden opgesteld voor de verschillende bedrijfssectoren en wordt daarnaast ook verbijzonderd naar bedrijfsgrootte. Bij de beroepsgroepen en opleidingstypen zal de mate waarin de werkenden geconfronteerd worden met technologische vernieuwingen worden toegespitst op ontwikkelingen op het gebied van de informatisering.

Om de derde risicogroep in beeld te brengen, zal in hoofdstuk 4 een overzicht worden gegeven van de bedrijfssectoren, beroepen en opleidingen die in de nabije toekomst te kampen hebben met een teruglopende werkgelegenheid of met verschuivingen in de aard van de werkgelegenheid. Daarbij wordt ook de onderlinge relatie tussen de krimpende sectoren, beroepen en opleidingen aangegeven. Met name in de vraagontwikkeling per opleidingstype weerspiegelen zich de technologische ontwikkelingen die in hoofdstuk 3 werden besproken.

Ook zal nader worden ingegaan op de positie van oudere arbeidskrachten. Veel oudere werknemers hebben naar verwachting te maken met functie-inhoudelijke kwalificatieveroudering: de kwalificatievereisten voor de functies die zij uitoefenen zijn in de loop der tijd veranderd, mede als gevolg van de geweldige ontwikkelingen op technologisch vlak. Van oudsher hebben oudere werknemers wat meer moeite met het volgen van dergelijke ontwikkelingen. Om na te gaan voor welke groepen, naast de ouderen, het risico van verlies van werk door kwalificatieveroudering wordt versterkt door een kwetsbare positie op de arbeidsmarkt, worden in dit vierde hoofdstuk tevens de bedrijfssectoren en opleidingstypen in kaart gebracht waarin veel arbeidskrachten met een flexibel contract werkzaam zijn. Tevens zal een beeld worden geschetst van de mate waarin er in de diverse bedrijfssectoren op bedrijfsniveau sprake is van baanvernietiging.

Tegenover de risico's van kwalificatieveroudering, staan de inspanningen op scholingsgebied en de employability van de werkenden in de zin van hun functionele flexibiliteit. In hoofdstuk 5 zullen de scholingsinspanningen en de functionele flexibiliteit van de werkenden aan de orde komen. Ook hier zullen de indicatoren worden verbijzonderd naar bedrijfsgrootte, bedrijfssector, beroep en opleiding. Voorts zal in hoofdstuk 5 extra aandacht worden geschonken aan de rol van bemiddelende instanties als uitzendbureaus, mobiliteitscentra en outplacementbureaus. Dit om een beeld te kriigen van hun rol bij het inperken van het verlies van werk door werkenden die geconfronteerd worden met één van de vormen van kwalificatieveroudering.

In hoofdstuk 6 vindt vervolgens de confrontatie plaats tussen enerzijds de belangrijkste risicogroepen voor wat betreft het verlies van werk door kwalificatjeveroudering en anderzijds de feitelijke scholingsinspanningen en de functionele flexibiliteit van de werkenden om dit risico te beperken. Op deze wijze worden de belangrijkste potentiële doelgroepen voor het scholingsbeleid gericht op behoud van werk getraceerd.

In aansluiting daarop zal in hoofdstuk 7 worden aangegeven op welke wijze deze potentiële doelgroepen door bij-, her- of omscholing hun posirie op de arbeidsmarkı zouden kunnen verbeteren. Hierbij zal het accent worden gelegd op kansrijke omscholingsactiviteiten en substantiële bijscholingsactiviteiten gericht op het behalen van een hoger opleidingsniveau. Voor zover slechts bijscholing op beperkte schaal vereist is, is het immers vanzelfsprekend in welke richting deze plaatsvindt. Startpunt voor het des- 
tilleren van de gewenste scholingstrajecten zijn uiteraard de arbeidsmarktsegmenten met gunstige arbeidsmarktperspectieven.

Een realistisch scholingsbeleid zal, zoals gezegd, ook rekening moeten houden met de verwantschap tussen de kwalificaties van de werkenden en de kwalificaties die op de arbeidsmarkt een goed perspectief bieden. Bovendien zal bij degenen die vanwege de fysiek of psychisch belastende arbeidsomstandigheden niet langer in staat zijn hun huidige functie uit te oefenen, moeten worden gekeken naar perspectiefrijke arbeidsmarktsegmenten, waar men niet of minder vaak onder dezelfde of vergelijkbare belastende arbeidsomstandigheden hoeft te werken. 


\section{Arbeidsomstandigheden}

\subsection{Inleiding}

Arbeidsomstandigheden kunnen een belangrijke rol spelen bij de veroudering van kwalificaties, voor zover ze van invloed zijn op de veiligheid, de gezondheid en het welzijn van werkenden op en rond de werkplek. Wanneer werkenden door fysiek of psychisch belastende omstandigheden op den duur hun werk niet meer kunnen uitoefenen zullen ze waarschijnlijk moeten uitwijken naar ander werk. Hierdoor is een deel van de kwalificaties waarover deze werkenden beschikten niet meer productief in te zetten.

De invloed van verslechterde arbeidsomstandigheden op de veroudering van kwalificaties blijkt met name te lopen via psychische en fysieke slijtage. Uit het in het kader van het WSO uitgebracht themarapport Scboling van werkenden (De Grip c.s., 1999) komt naar voren dat het risico van slijtage groter word naarmate werknemers meer te maken kriigen met belastende arbeidsomstandigheden. Met name het herhalen van dezelfde eenvoudige werkzaamheden en het doen van geestelijk zwaar werk blijken het risico van slijtage sterk te vergroten. Andere factoren die een rol spelen zijn: stank, lawaai, tocht, hoge of juist lage temperaturen en gevaarlijke werkomstandigheden.

Dat binnen ondernemingen sprake is van slechte arbeidsomstandigheden kan een tweetal hoofdoorzaken hebben (De Koning c.s., 1996). In de eerste plaats kan er sprake zijn van een hevige concurrentie op de afzetmarkten van bedrijven. Dit verplicht werkgevers om de kosten te minimaliseren. Deze bezuinigingen kunnen leiden tot een verslechtering van cle arbeidsomstandigheden.

Een andere oorzaak voor het gegeven dat bepaalde groepen werkenden langdurig te maken hebben met slechte arbeidsomstandigheden ligt in het ontbreken van mogelijkheden voor bepaalde groepen werkenden om door te stromen naar minder belastende functies. Dit geldt vooral voor laag opgeleiden, die immers slechts beperkte verticale doorstroomcapaciteiten hebben. Omdat deze werknemers weinig uitwijkmogelijkheden hebben naar andere functies staan zij bovendien zwak bij onderhandelingen voor betere arbeidsomstandigheden. Door scholing kunnen de uitwijkmogelijkheden voor deze arbeidskrachten eventueel worden vergroot, waardoor hun positie op de arbeidsmarkt wordt versterkt, zodat uitval niet meer de enige uitweg is.

\section{Belastende arbeidsomstandigheden komen zelden alleen}

Uit de overzichtsrapportage Werkgelegenbeid en scholing 1997 bleek dat het vaker voorkomt dat werknemers in een bepaald beroep tegelijkertijd met meerdere belastende arbeidsomstandigheden te maken krijgen. Tabel 2.1 maakt duidelijk dat dit ook nog steeds opgaat. De fysieke belastingsfactoren trilling, lawaai, kracht en in iets mindere mate ook ploegendienst gaan vaak samen. De psychische belastingsfactor tijdsdruk correleert daarentegen negatief met de genoemde fysieke belastingsfactoren. Uit de vorige rapportage Werkgelegenheid en scholing 1997 bleek dat fysieke belasting vooral voorkomt in lagere beroepen en psychische belasting in de hogere. 
Tabel 2.1

Correlatie van belastende arbeidsomstandigheden gespecificeerd naar beroepsgroep. 1998

$\begin{array}{lrrrrr} & \text { Ploegendienst } & \text { Kracht } & \text { Lawaai } & \text { Trilling } & \text { Tijdsdruk } \\ \text { Ploegendienst } & 1 & & & & \\ \text { Kracht } & 0,53 & 1 & & & \\ \text { Lawaai } & 0,45 & 0,61 & 1 & & \\ \text { Trilling } & 0,25 & 0,65 & 0,71 & 1 & \\ \text { Tijdsdruk } & -0,09 & -0,49 & -0,37 & -0,32 & 1\end{array}$

Bron: $\mathrm{CBS} / \mathrm{ROA}$

\section{Opzet hoofdstuk}

In paragraaf 2.2 zal allereerst aan de hand van de bestaande theorievorming en beschikbare informatie aandacht worden geschonken aan het verband tussen belastende arbeidsomstandigheden, de kans op kwalificatieveroudering en het risico van verlies van werk.

Vervolgens wordt in paragraaf 2.3 een overzicht gegeven van de mate waarin werknemers in risicovolle omstandigheden werkzaam zijn. In deze paragraaf wordt in kaart gebracht in welke bedrijfssectoren, beroepsgroepen en opleidingstypen belastende arbeidsomstandigheden het vaakst voorkomen. Er zal een onderscheid gemaakt worden tussen fysiek (trilling, lawaai en kracht zetten) en psychisch belastende arbeidsomstandigheden (tijdsdruk). Daarnaast wordt gekeken naar het werken in ploegendienst, een arbeidsomstandigheid die zowel fysiek als psychisch haar tol eist (zie bv. Foss, 1997). In de bijbehorende Statistische Bijlage is een volledig overzicht opgenomen van de mate waarin werkenden in de verschillende bedriffssectoren, beroepen en opleidingstypen geconfronteerd worden met belastende omstandigheden.

In paragraaf $2.4 \mathrm{zal}$ ter verdieping van de eigen onderzoeksresultaten aandacht worden geschonken aan RS1 als werkgerelateerd risico. Naast de reeds onderzochte belastingsfactoren zal hierbij in het bijzonder worden gekeken naar psychische factoren als beslissingsvrijheid en bijvoorbeeld werksfeer. In deze paragraaf draait het vooral om resultaten wit een tweetal studies, uitgevoerd door TNO (Blatter en Bongers, 1999) en CBS (Otten C.s., 1998).

Ten slotte wordt in paragraaf 2.5 een samenvattend overzicht gegeven van die hedrijfssectoren, beroepen en opleidingstypen waarvoor de risico's op kwalificatieveroudering vanwege fysiek en/of psychisch belastende arbeidsomstandigheden het grootst zijn.

\subsection{Belastende arbeidsomstandigheden, kans op kwalificatieveroudering en risico op verlies van werk}

In het verleden is veel onderzoek gedaan naar het verband tussen slechte arbeidsomstandigheden en het verlies van werk als gevolg van letsel en ziekte. Dit grote aantal onderzoeken is onder te verdelen in twee hoofdcategorieën: het onderzoek dat uitgaat van persoonsgebonden oorzaken van uitval (bv. Kruidenier, 1980) en onderzoek dat uitgaat van bedrijfsgebonden oorzaken (bv. Houtman c.s., 1998; Blatter en Bongers, 1999). 
In een recente studie van Otten c.s. (1998) worden overigens beide oorzaken geanalyseerd. Persoonsgebonden oorzaken van uitval zijn bijvoorbeeld een hoge leeftijd en een lage opleiding. Dat werkenden op hogere leeftijd vaker problemen ondervinden met hun fysieke gesteldheid heeft overigens ook te maken met slechtere arbeidsomstandigheden in eerdere fases in de loopbaan, waardoor zij al een relatief slechte fysieke gesteldheid hebben.

Een van de belangrijkste bedrijfsgebonden oorzaken van uitval is de toenemende belasting van werknemers. Deze toenemende belasting kan ertoe leiden dat werknemers overbelast raken. Overbelasting kan zowel voor psychische als voor fysieke problemen zorgen, wanneer werknemers niet zelf in staat zijn om de werkdruk te beïnvloeden (zie ook: Karasek en Theorell, 1990). De werkstress en chronische vermoeidheid die het gevolg zijn van de overbelasting leiden tot ziekteverzuim en op den duur zelfs tot uitval c.q. verlies van werk. Behalve werkdruk kunnen ook verstoorde arbeidsverhoudingen (relaties op het werk) voor de nodige stress zorgen.

De persoonsgebonden en bedrijfsgebonden oorzaken van uitval versterken elkaar overigens in de meeste gevallen. De Grip c.s. (1999) tonen aan dat het risico van kwalificatieveroudering door slijtage als gevolg van belastende arbeidsomstandigheden groter wordt naarmate de leeftijd van werkenden hoger is. Oorzaken hiervoor kunnen gezocht worden bij het autonome, biologische verouderingsproces dat gepaard gaat met een verminderende verwerkingscapaciteit, waardoor herstel na een zware belasting steeds minder snel plaatsvindt (Salthouse, 1994). Wanneer een werkende niet meer voldoende kan herstellen na een zware belasting, dan ontstaan problemen als stress en oververmoeidheid.

Meiiman (1991) maakt in zijn belasting/herstel model cen tweedeling in de effecten van een verhoogde belasting: de reversibele effecten (de effecten van belasting, warvan men kan herstellen) en de irreversibele (onomkeerbare) effecten. Deze laatste categorie effecten tast de werkcapaciteit van de werknemer dusdanig aan dat blijvende schade ontstaat, waardoor het risico van verlies van werk groot is. Tot deze categorie effecten behoort bijvoorbeeld blijvende gehoorschade door lawaai of letsel dat het gevolg is van bedriffsongevallen.

In Werkgelegenheid en scholing 1997 is onderzocht in hoeverre de kans op arbeidsongeschiktheid stijgt bij blootstelling aan lawaai en trilling, het veel kracht moeten zetten en het werken onder tijdsdruk. Met name de belastingsfactoren kracht en lawaai bleken bij deze analyse de kans op arbeidsongeschiktheid te vergroten. Daarentegen werd er geen verband geconstateerd tussen de mate warin mensen met een bepaalde opleidingsachtergrond vaak onder tijdsdruk moeten werken en hun kans op arbeidsongeschiktheid. Op individueel niveau blijkt er echter wel degelijk een relatie tussen een hoge werkdruk en het risico van arbeidsongeschiktheid te bestaan. Geschat wordt dat ruim $20 \%$ van de werkenden in de dienstverlenende beroepen last heeft van burnout ${ }^{1}$ Weinig regelmogelijkheden, een hoge werkdruk en regelmatig contact met klanten patiënten of leerlingen blijken aan de basis te staan van deze problemen.

1 Zie ook internetsite:bup:wwu inlermediairnl/esthumoutindex.hm/ 
In De Grip c.s. (1999) is de kans op langdurig ziekteverlof gekoppeld aan diverse belastende arbeidsomstandigheden. Uit deze analyse bleek dat het werken onder fysiek belastende omstandigheden, waaronder ook lawaai, de kans op langdurig ziekteverlof verhoogt. Ook bleek psychische belasting deze kans te vergroten. Dat persoonsgebonden factoren een versterkende rol kunnen spelen blijkt uit het feit dat bijvoorbeeld het vorderen van de leeftijd de kans op langdurig ziekteverlof vergroot.

\subsection{Arbeidsomstandigheden: fysieke en psychische belasting}

\section{Bedrijfssector}

In figuur 2.1 zijn de tien bedrifssectoren weergegeven die voor wat betreft fysieke belasting de minst aantrekkelijke arbeidsomstandigheden bieden voor werknemers. Evenals twee jaar geleden blijken de werkenden in de sector bouw het meest te worden geconfronteerd met fysiek belastende arbeidsomstandigheden. Uit nadere analyse blijkt de bouwsector op elk van de drie fysiek belastende arbeidsomstandigheden erg hoog te scoren, waarbij vooral de hoge score voor trilling eruit springt. Overigens is het niet vreemd dat deze sector op fysiek gebied het meest eist van de werknemers. Werken in de bouw betekent immers tillen, sjouwen en werken met de meest uiteenlopende gereedschappen; niet alleen troffels en hamers, maar ook zwaar gereedschap zoals drilboren.

\section{Figuur 2.1}

Bedrijfssectoren waarin de arbeidsomstandigheden sterk fysiek belastend zijn, volgens de samengestelde indicator*, 1998

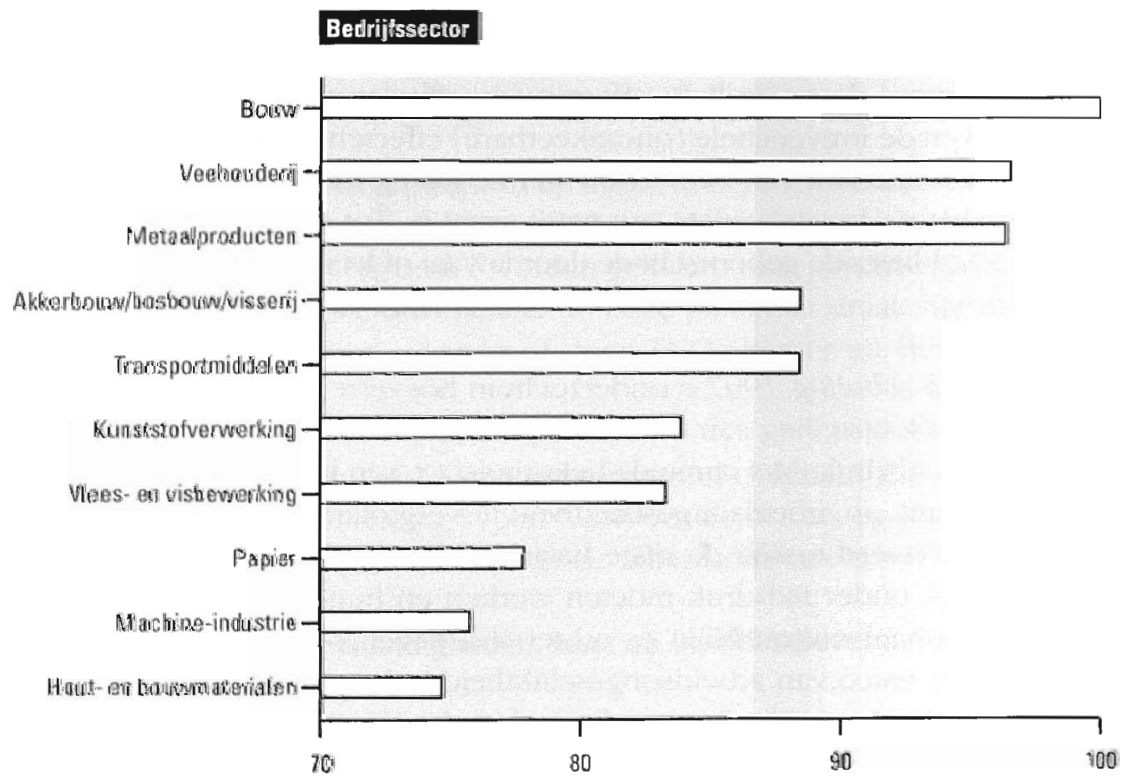

* De indicator voor fysieke belasting is een combinatie van een drietal belastingsfactoren: lawaai, trilling en kracht zetten.

Bron: CBS/ROA 
Ook het werk in de sectoren veebouderij en akkerbouw, bosbouw en visserij brengt de nodige risico's met zich mee. De grootste bedreiging voor de gezondheid van de werkenden binnen deze beide sectoren is dat men veelvuldig kracht moet zetten. Ook lawaai speelt een erg belangrijke rol, bijvoorbeeld in de bosbouw, waar veel met kettingzagen wordt gewerkt.

\section{Belastende arbeidsomstandigheden in de bouw}

De uitvoeringsorganisatie van het Sociaal Fonds Bouwnijverheid voert op het gebied van arbeidsomstandigheden in de bouw met name preventief beleid. Het streven daarbij is de uitstroom als gevolg van belastende arbeidsomstandigheden tot een minimum te beperken. Eén van de mogelijkheden om deze uitstroom af te remmen is het verlenen van subsidies voor het aanschaffen van gereedschappen die het werk lichter maken en het geven van voorlichting over een betere werkhouding. Ook als een werknemer vanwege (gedeeltelijke) arbeidsongeschiktheid zijn werkzaamheden al niet meer kan verrichten, komt de SFB in beeld.

De SFB is onder anderen belast met het uitvoeren van de Wet Reïntegratie Arbeidsgehandicapten (Wet REA). Kern van deze wet is dat arbeidsgehandicapten instrumenten kriigen aangereikt om hun baan te behouden of om een nieuwe baan te vinden. Werkgevers worden gestimuleerd om arbeidsgehandicapten in dienst te nemen. In deze nieuwe regeling staan drie elementen centraal: snellere procedures, bijdrage in de kosten van het in dienst nemen en extra faciliteiten voor het in dienst houden van arbeidsgehandicapte werknemers. Met het tweede element wordt beoogd in de kosten van interne herplaatsing van arbeidsgehandicapten tegemoet te komen. Lukt deze herplaatsing niet, dan kunnen de werkgever en werknemer een beroep doen op de regeling voor de extra faciliteiten. Hierbij kan gedacht worden aan mogelijkheden voor scholing of subsidie.

Aan werkgevers worden de volgende instrumenten aangereikt om arbeidsgehandicapte werknemers in dienst te houden of te nemen:

- vergoeding voor werkaampassing in de vorm van subsidies;

- berplaatsingsbudget: indien een werkgever een arbeidsgehandicapte werknemer kan herplaatsen naar een andere functie binnen het bedrijf komt hij in aanmerking voor een eenmalige vergoeding van $f 8.000$;

- plaatsingsbudget: indien een werkgever een arbeidsgehandicapte sollicitant in dienst neemt dan ontvangt deze een budget om de kosten van productieverlies, scholing, begeleiding, werkplekaanpassingen en de aanschaf van hulpmiddelen te vergoeden;

- pakket op maat, vergoeding van alle kosten: indien de kosten voor een werkgever hoger zijn dan het herplaatsingsbudget dan kan een werkgever aanspraak maken op het pakket op maat;

- proefplaatsing: als een werkgever eerst wil weten of een in dienst te nemen arbeidsgehandicapte werknemer het werk aankan, dan kan in gezamenlijk overleg besloten worden tot proefplaatsing;

- koring op WAO-basispremie: als een werkgever 3 tot 5\% van zijn loonsom besteedt aan arbeidsgehandicapte werknemers dan krijgt hij een korting op of zelfs kwijtschelding van de te betalen WAO-basispremie; 
- loonkastenvergoeding bij ziekte: als een werkgever een arbeidsgehandicapte werknemer in dienst neemt en deze wordt ziek dan vergoedt SFB de eerste vijf jaar het grootste deel van het loon.

Bovenstaande maatregelen stimuleren werkgevers in de bouwnijverheid om arbeidsgehandicapte werknemers te behouden of in dienst te nemen; de arbeidsmarktuitstroom wordt daarmee afgeremd. Daarnaast betekent dit eveneens dat voor arbeidsgehandicapte werknemers het werkzame leven niet stopt bij het hebben van een arbeidshandicap.

Bron: SFB Uitwoeringsorganisatie Sociale Verzekering N.V., Weer aan de slag, 1999

Nieuw in de top tien van bedrijfssectoren waarbinnen de arbeidsomstandigheden fysiek het meest belastend zijn, zijn de sectoren macbine-industrie en de papier industrie, die de plaats innemen van de sectoren reparatie en basismetaal. De hogere positie van de macbine-industrie is overigens niet te wijten aan een verslechtering van de arbeidsomstandigheden, maar aan het feit dat de verbetering van de arbeidsomstandigheden in deze sector achterblift bij die in de meeste andere sectoren.

Ook in de sector papier is de verslechtering van de arbeidsomstandigheden niet groot. Dat de sector basismetaal uit de top tien verdwijnt, dankt zij aan het feit dat in deze sector voor elk van de drie fysieke belastingsfactoren sprake is van een daling van het percentage werkenden dat ermee te maken heeft met gemiddeld 7\%-punt.

In nagenoeg alle sectoren is overigens sprake van een daling van het percentage werkenden dat zegt te maken te hebben met belastende arbeidsomstandigheden. Met name de factor lawaai lijkt steeds meer onder controle te komen. In elf van de dertien op het hoogste aggregatieniveau te onderscheiden bedrijfssectoren is het percentage werkenden dat met lawaai wordt geconfronteerd met ongeveer 3\%-punt gedaald. In de overige twee sectoren, kwataire diensten en energie is het percentage gelijk gebleven.

Wanneer de fysieke belastingsfactoren elk afzonderlijk worden bezien ${ }^{3}$, blijkt dat lawaai met name in de sectoren papier en metaalproducten een belangrijke risicofactor is. Ruim de helft van de werkenden in deze sectoren zegt met lawaai te worden geconfronteerd. Uit onderzoek van Den Boer en Reubsaet (1995) blijkt dat beide sectoren ook voorkomen in de top tien van bedrifstakken met relatief veel werkenden in lawaaiexpositieniveaus boven 80 decibel (het niveau waarop bescherming van het gehoor wettelijk verplicht is). Trilling komt nog steeds het meest voor in de sector bout:

De sector veebouderij neemt een tweede plek in. In beide sectoren geldt dat ongeveer de helft van de werkenden werkt met een apparaat of gereedschap dat trilling veroor-

2 Dat de bedrijtsklasse reparatie niet langer in de top tien staat vindt hatr oorzaak in een herindeling

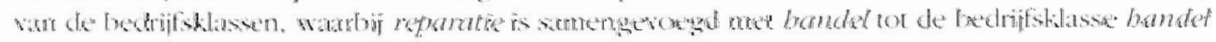
en reparatie

3 Zie ook tabellen 2.1 for en met 2.3 in de Statistiscbe Bijlage. 
zaakt. 71 Procent van de werkenden in de sector veebouderij moet bovendien regelmatig kracht zetten tijdens het werk, tegenover $64 \%$ in de bouw. Uit onderzoek van Delleman c.s. (1995) komt naar voren dat in de sectoren bouw en land-en tuinbouw veel geduwd, getild, gedragen en getrokken wordt en dat al deze belastingsfactoren samengaan met een verhoogde kans op lage rugklachten.

In figuur 2.2 worden de bedrijfssectoren gepresenteerd, waarbinnen werknemers het vaakst te maken krijgen met psychisch belastende arbeidsomstandigheden, in de vorm van tijdsdruk ${ }^{4}$. Over het algemeen blijft het percentage werkenden dat onder hoge tijdsdruk werkt vrij constant op een relatief hoog niveau. Net als bij de vorige rapportage blijken met name werkenden in de sectoren scheep-en luchtvaart en grafische industrie onder hoge tijdsdruk te werken. In de grafische industrie is de hoge tijdsdruk vrij gemakkelijk te verklaren, aangezien men vaak met deadlines werkt. In de scheep-en iuchtvaartsector is het hoge percentage werkenden dat met tijdsdruk te maken heeft ook goed te verklaren uit de strakke vlieg- en vaarschema's waarmee wordt gewerkt. De tijdsdruk wordt nog versterkt door de drukte in de lucht en op het water. Overigens is het percentage werkenden dat in deze sector en in de sector weg-en railvervoer onder hoge tijdsdruk werkt niet toegenomen, maar constant gebleven.

Figurur 2.2

Bedrijfssectoren met het hoogste percentage werkenden dat onder hoge tijdsdruk werkt, 1998

\section{Bedrijissector}

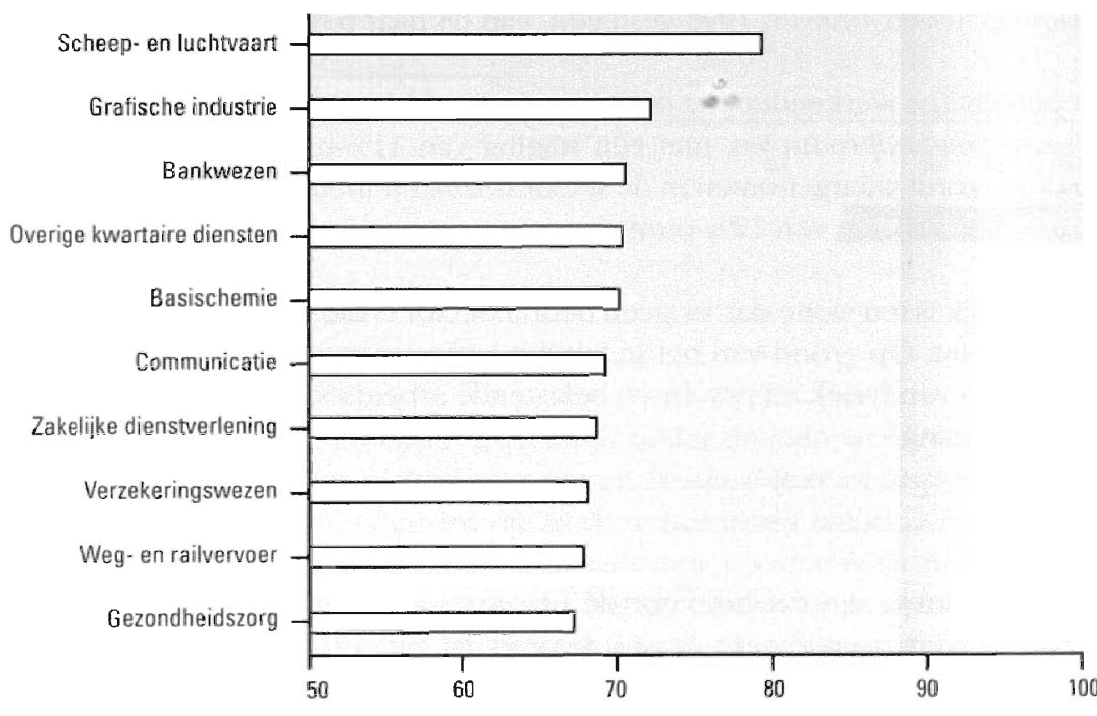

Hoge tijdsdruk (\%)

Bron: CBS/ROA

4 Zie ook tabel 2.5 in de Statistiscbe Biflage. 
Ook in de andere dienstverlenende sectoren blijkt de tijdsdruk vrij hoog. In de sectoren bankwezen, verzekeringswezen, overige kwartaire diensten en zakelijke dienstverlening wordt onder hoge tijdsdruk gewerkt. De toenemende concurrentie in deze sectoren en de neiging van dienstverlenende instanties om te concurreren op het gebied van klantgerichtheid en snelheid zijn hiervoor in belangrijke mate verantwoordelijk.

De sector verzekeringswezen kwam twee jaar geleden niet voor in de top tien van bedrijfssectoren met het hoogste percentage werkenden dat onder hoge tijdsdruk werkt. Het percentage werkenden in deze sector dat onder hoge tijdsdruk werkt is ten opzichte van 1997 met 7\%-punt gestegen. Dat ook in deze sector sprake is van hoge tijdsdruk kan mogelijk mede worden verklaard door het feit dat verzekeringsmaatschappijen vooral de laatste jaren bezig zijn een 'nieuwe' markt te veroveren die is vrijgekomen als gevolg van de gedeeltelijke privatisering van de sociale zekerheid (afschaffing Ziektewet, beperken WAO-uitkeringen en VUT-faciliteiten). Omdat verzekeringsmaatschappijen en pensioenverzekeraars zich een plek op deze markt willen verschaffen dienen voortdurend nieuwe en aantrekkelijke producten te worden ontwikkeld om de concurrentie de loef af te steken. Deze prestatiedruk kan voor medewerkers tot een verhoogde tijdsdruk leiden,

Ook de sector gezondbeidszorg behoort nu tot de tien bedrijfssectoren waar de tijdsdruk het hoogst is, maar binnen deze sector spelen hele andere factoren een rol. Met name de toenemende regulering van de werkzaamheden, de structurele onderbezetting vanwege personeeltekorten (De Grip, 1998) en het feit dat vaak snel gehandeld dient te worden omdat mensenlevens in het geding zijn voert de druk in deze sector vaak sterk op. Het percentage werkenden in de gezondheidszorg dat onder hoge tijdsdruk zegt te werken is tussen 1996 en 1998 gestegen, van 63 naar $67 \%$.

Het percentage werkenden dat onder hoge tijdsdruk werkt is het sterkst toegenomen in de sector metaalproducten, met een stijging van $11 \%$-punt. De sterkste daling van de tijdsdruk wordt waargenomen in de sector drank en tabaksproducten waar ten opzichte van 1996 een daling van 12\%-punt wordt waargenomen.

Opmerkelijk is ten slotte dat er geen bedrijfssector is die zowel in figuur 2.1 als in figuur 2.2 voorkomt. Op grond van het in tabel 2.1 aangegeven negatieve verband tussen het voorkomen van fysiek en psychisch belastende arbeidsomstandigheden is dat overigens geen verrassing

\section{Beroep}

Het zal duidelijk zijn dat het voor de belasting van werkenden veel uitmaakt in welk beroep zij werkzaam zijn. In deze subparagraaf zal een beeld worden gegeven van de beroepen waarin fysiek en psychisch belastende factoren het meest voorkomen 5 .

In figuur 2.3 wordt een overzicht gegeven van de beroepen waarin de arbeidsomstandigheden het meest fysiek belastend zijn. Het eerste dat opvalt is dat het met name de

5 Zie ook tabellen 2.6 tot en met $2.11,2.14$ en 2.15 in de Statistische Bijlage 
technische beroepen zijn, die in deze top tien te vinden zijn. Uitzonderingen hierop zijn de stewards en de landbouwmachinebestuurders en vissers. Bovendien gaat het hier met name om lagere en middelbare beroepen. Dat laatste is niet verrassend. Het zijn immers met name de 'blauwe boorden' beroepen die te maken krijgen met zware gereedschappen en lawaaierige machines.

\section{Figuur 2.3}

Beroepsgroepen waarvoor de arbeidsomstandigheden sterk fysiek belastend zijn, volgens de samengestelde indicator*, 1998

\section{Beroepsklasse}

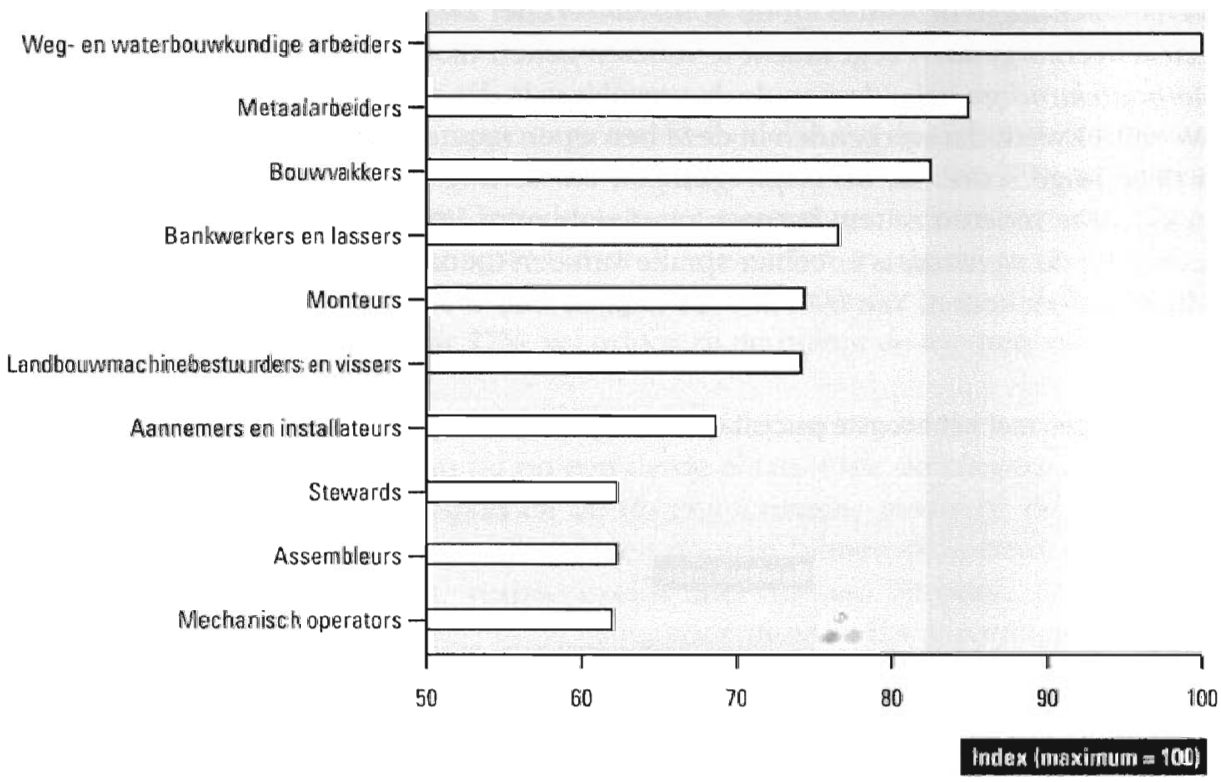

*Zie figuur 2.1

Bron: $\mathrm{CBS} / \mathrm{ROA}$

Wanneer de afzonderlijke fysieke belastingsfactoren onder de loep worden genomen is te zien dat lawaai met name voor metaalarbeiders en bankwerkers en lasserseen belastingsfactor vormt. Bijna $70 \%$ van degenen die in deze beroepen werkzaam zijn zegt te worden geconfronteerd met lawaai. Zij werken dan ook voornamelijk met lawaaige frees- en slijpmachines. Opvallend is echter dat het de zweminstructeurs zijn dic het meest met lawaai te maken hebben. 78 Procent van de zweminstructeurs zegl met lawaai te worden geconfronteerd. Zij werken dan ook de hele dag in een galmende zwemhal. Uit een vergelijking met de cijfers van twee jaar geleden blijkt dat het percentage werkenden dat te maken heeft met lawaai over vrijwel de gehele linie is gedaald. Een uitzondering vormen de grafische vakkrachten. Van deze latste grop is het percentage werkenden dat met lawaai wordt geconfronteerd met 5\%-punten toegenomen. 
De werkenden die het meest met trilling te maken hebben zijn de weg-en waterbouwkundige arbeiders, de metalarbeiders en de bouwvakkers. Ongeveer $70 \%$ van de werkenden in deze beroepen zegt met gereedschap of apparaten te werken die trilling veroorzaken. De tien beroepsgroepen waarin de werkenden het meest met trillingen te maken hebben zijn vrijwel dezelfde als twee jaar geleden. Wel blijkt dat de werkenden in deze beroepsgroepen, met uitzondering van de weg-en waterbouwkundige arbeiders en de elektromonteurs, minder met trilling worden geconfronteerd dan bij de vorige rapportage het geval was. Voor de weg-en waterbowwkundige arbeiders en de elektromonteurs kan dit twee dingen betekenen: of er is sprake van een structureel probleem, waardoor het moeilijk is om voor deze beroepsgroepen trilling te voorkomen of er is in deze beroepsgroepen nog te weinig aandacht voor trilling als belastingsfactor. Wat het kracht moeten zetten betreft, hebben met name de ziekenverzorgenden, de weg-en waterbouwkundige arbeiders en de bouwvakkers het zwaar te verduren. Bijna $90 \%$ van de ziekenverzorgenden zegt kracht te moeten zetten tijdens het werk. Van de weg-en waterbouwkundige arbeiders en de bouwvakkers is dat ruim $85 \%$. Het vele sjouw-, til-, duw- en trekwerk dat werkenden in deze beroepen moeten verrichten staat aan de basis van deze hoge score. Bij de verpleeghulpen en leerling-verpleeghulpen zegt ongeveer $85 \%$ kracht te moeten zetten, hetgeen overigens ruim 5\%-punt minder is dan twee jaar geleden. Bij de stewards is er echter sprake van een toename van het aantal werkenden dat kracht moet zetten. Van $69 \%$ in 1996 naar $80 \%$ in 1998.

Figuur 2.4

Beroepsgroepen met het hoogste percentage werkenden die onder hoge tijdsdruk werken, 1998

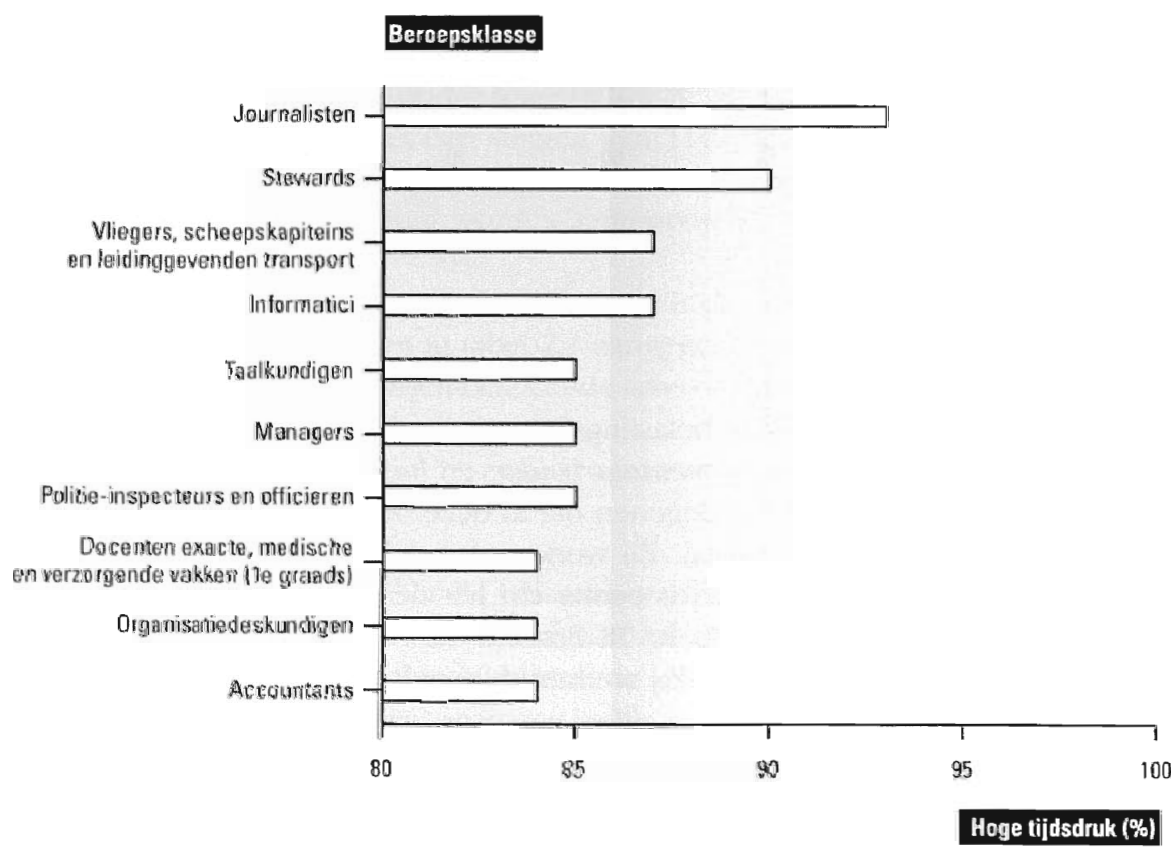

Bron: CBS/ROA 
Figuur 2.4 geeft een overzicht van de beroepsgroepen waarin de werkenden te maken hebben met hoge psychische belasting c.q. tijdsdruk ${ }^{6}$. Het zijn voornamelijk de hogere beroepen, waarin veel onder een hoge tijdsdruk wordt gewerkt. Bij de journalisten en de stewards is de werkdruk op dit punt het grootst. De eerste groep heeft dagelijks te maken met deadlines voor het opleveren van artikelen. De tweede groep met steeds strakker wordende reisschema's. Dit laatste verklaart ook de hoge tijdsdruk bij de vliegers, scheepskapiteins en leidinggevenden transport. Dat ook de informatici onder hoge tijdsdruk werken heeft naast het werken met scherpe deadlines waarschijnlijk ook te maken met de snelle ontwikkelingen op technologisch vlak, waardoor de behoefte aan (computer)ondersteuning steeds groter wordt. Waar de behoefte aan informatici alleen maar groter wordt blifft het aanbod ervan de laatste jaren structureel achter. (Smits, Delmee en De Grip, 1998). Dat terwijl de informatici, afgezien van de geneeskundigen en fiscaal juristen, nu al de langste dagen maken: gemiddeld 40,1 uren per week (Geiss, 1997).

Een vergelijking met de vorige rapportage maakt duidelijk dat de tijdsdruk in een aantal beroepen aanzienlijk is toegenomen. Van de informatici zei in $199679 \%$ te maken te hebben met een hoge tijdsdruk. Inmiddels is dat percentage toegenomen tot $87 \%$. De tien beroepsgroepen met de hoogste tijdsdruk verschillen overigens sterk van die van de vorige rapportage. Het percentage bedriffshoofden dat onder hoge tijdsdruk werkt is met $13 \%$-punt fors gedaald naar $77 \%$, waardoor zij nu buiten de top tien vallen.

De informatici, die twee jaar geleden nog niet tot de werkenden behoorden voor wie de tijdsdruk het hoogst is, staan nu op een derde plaats. Ook de vliegers, scheepskapiteins en leidinggevenden transpont en de docenten exacte, mediscbe en verzorgende vakken (1e graads) zijn nieuw in de top tien doordat binnen deze beroepsklassen de tijdsdruk fors is toegenomen, respectievelijk met 10- en 9\%-punt. Enkele andere beroepsgroepen komen niet meer in de figuur voor, doordat het percentage werkenden dat onder hoge tijdsdruk werkt stevig is gedaald. Hierbij vallen naast de reeds genoende bedrijfshoofden ook de weg-en waterbouwkundigen (-8\%-punt), de ecomomen (-10\%punt), de tecbnisch systeem analisten (-11\%-punt) en de teidinggevenden (-6\%-punt) op.

De stewards behoren zowel voor wat betreft psychische als voor wat betreft fysieke belasting tot de tien beroepsgroepen die het meest worden belast. Voor de stewards is de kans op slijtage als gevolg van fysieke en psychische slijtage en dus het risico van verlies van werk als gevolg hiervan het grootst.

\section{Opleiding}

In de figuren 2.5 en 2.6 worden de tien opleidingstypen weergegeven die het valakst worden geconfronteerd met respectievelijk fysieke en psychische belastingsfactoren 7 . Een vergelijking met de cijfers uit 1996 maakt duidelijk dat voor nagenoeg elk opleidingstype de fysieke belasting wat minder is geworden. Bij de werkenden met een

6 Zie ook tabellen 2.14 en 2.15 in de Statistische Bijlage.

7 Zie ook de tabellen 2.16 tot en met 2.18 en 2.20 in de Statistiscbe Bijlage. 
opleiding VMBO landbouw en natuurlijke omgeving bijvoorbeeld is het percentage dat door lawaai en trilling wordt belast aanzienlijk gedaald, respectievelijk met 13- en 6\%punt.

Figuur 2.5

Opleidingstypen waarvoor de arbeidsomstandigheden sterk fysiek belastend zijn, volgens de samengestelde indicator ${ }^{*}, 1998$

\section{Opleidingstype}

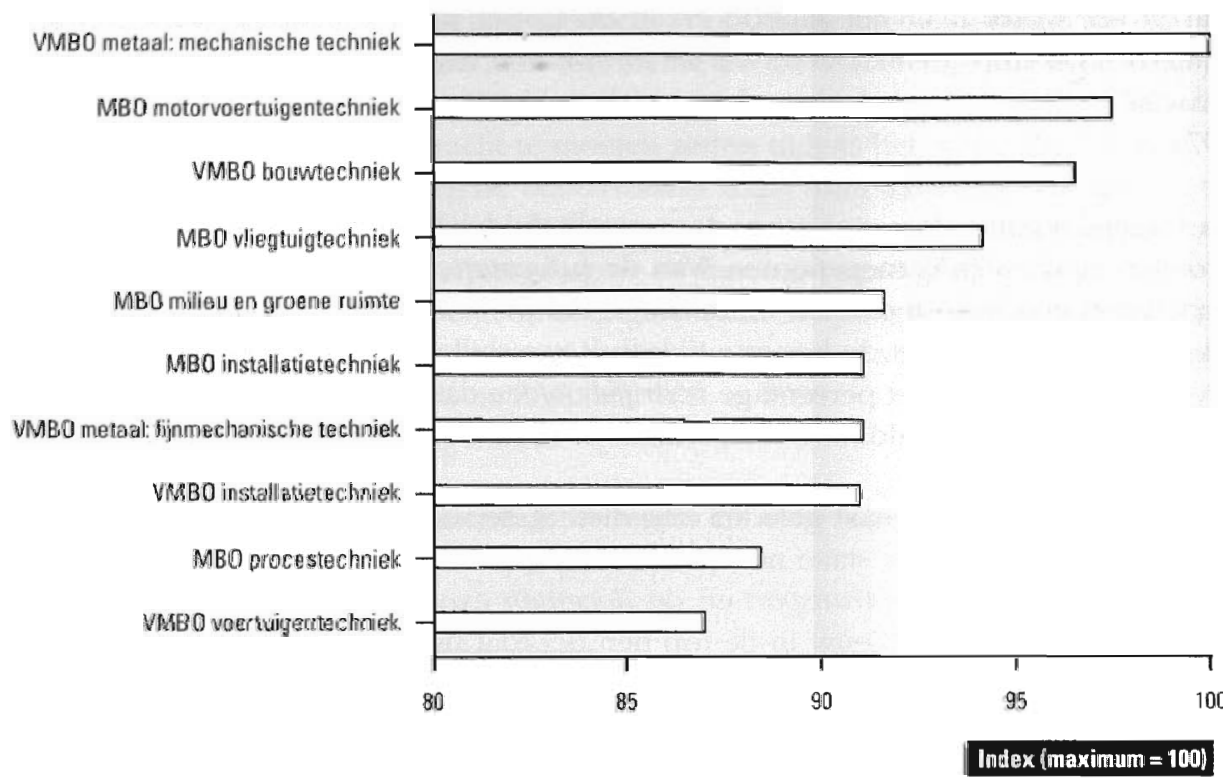

"Zie figuur 2.1

Bron: CBS/ROA

Uit figuur 2.5 blijkt wel dat met name lager en middelbaar opgeleiden te kampen hebben met fysieke belasting. Daarnaast blijkt dat vooral werkenden met een technische opleidingsachtergrond relatief vaak fysiek zwaar worden belast. Maar liefst negen van de tien opleidingen ziin technisch van aard. Het ergst is de fysieke belasting bij werkenden met een opleidingsachtergrond VMBO metaal: mechaniscbe techniek, gevolgd door MBO motonoentuigentechntek en VMBO bouwtechniek. Dit zijn overigens niet echt verrassende resultaten aangezien werkenden met een lagere technische achtergrond vaak terechtkomen op de fabrieksvloer, waar zij te maken hebben met grote lawalierige machines en relatief zwaar lichamelijk werk.

Als alleen de belastingsfactor lawaai in ogenschouw wordt genomen, blijkt dat vooral degenen met een opleiding MBO vliegtuigtechniek en MBO procestechniek, hier veel mee te maken hebben. Ruim $65 \%$ van de werkenden met deze opleidingsachtergrond zegt tijdens het werk te worden geconfronteerd met lawaai. Opvallend is verder dat HBO vervoer en logistiek (39\%), een opleiding op hoger niveau, ook in deze top tien te 
vinden is. De werkenden met de opleiding $M B O$ installatietechniek werken het vaakst met gereedschappen of apparaten die trilling veroorzaken. De helft van alle werkenden met deze opleidingsachtergrond heeft tijdens het werk met trilling te maken.

Ruim $60 \%$ van de werkenden met $M B O$ installatietechniek is overigens werkzaam als aannemer of installateur (ROA, 1998), een beroepsklasse waarin men tijdens het werk, zo bleek eerder in dit hoofdstuk, relatief veel met trillingen te maken heeft. Ook werkenden met de opleidingen MBO milieu en groene ruimte en MBO motonoertuigentechniek hebben tijdens hun werk relatief vaak te maken met trilling.

Kracht zetten gebeurt vooral door werkenden met VMBO bouwtechniek als opleidingsachtergrond. 73 Procent van hen geeft aan kracht te moeten zetten tijdens het werk.

Figuur 2.6

Opleidingstypen met het hoogste percentage werknemers dat onder hoge tijdsdruk werkt, 1998

\section{Opleidingstype}

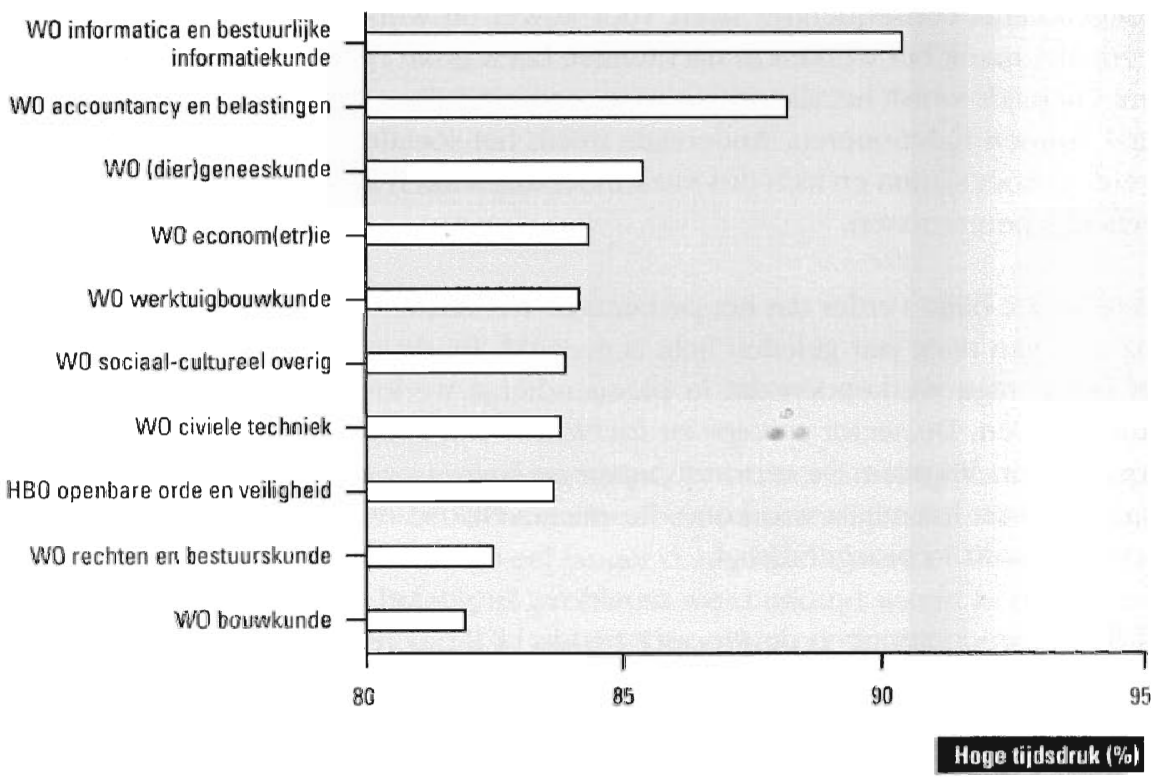

Bron: CBS/ROA

Bijna de helft van de werkenden met VMBO bouwtechniek blijkt werkzaam te zijn als bouwvakker (ROA, 1998a/b). In die functie hebben zij veel te tillen en te sjouwen en is het niet vreemd dat er veel kracht moet worden gezet. Ook de werkenden met VMBO installatietechniek en $M B O$ milieu en groene ruimte geven an valk kracht te moeten zetten tijdens hun werk. 
In figuur 2.6 staan de opleidingstypen genoemd waarvoor de psychische belasting het grootst is ${ }^{8}$. Het blijken met name de werkenden met een universitaire opleiding die het meest onder tijdsdruk moeten werken. Bij de werkenden met WO informatica en bestuurlijke informatiekunde is de tijdsdruk het grootst, met WO accountancy en belastingen op een tweede plaats. Ongeveer $90 \%$ van de werkenden met deze opleidingsachtergronden werkt onder hoge tijdsdruk. Dit kwam al tot uiting bij de tijdsdruk, verbijzonderd naar beroepsgroep, waar informatici en accountants ook hoog scoorden.

In vergelijking met de cijfers in de vorige rapportage is wel opvallend dat de werkenden met een opleiding WO informatica en bestuurlijke informatiekunde qua tijdsdruk toen nog slechts een gemiddelde score hadden, nu is die score te typeren als zeer hoog.

\section{Ploegendienst}

Tabel 2.2 geeft ten slotte een overzicht van de bedrijfsectoren, beroepsgroepen en opleidingstypen waar het meeste in ploegendienst wordt gewerkt. Het werken in ploegendienst kan zowel fysiek als psychisch belastend zijn. Meijman (1991) geeft aan dat ploegendienst consequenties heeft voor zowel de werksituatie als het leven daaromheen. Met name het werken in nachtdienst heeft grote fysieke en psycho-sociale gevolgen. Enerzijds wordt het slaapritme verstoord, waardoor veel werkenden niet meer optimaal kunnen functioneren. Anderzijds wordt het sociale leven aangetast, doordat men overdag moet slapen en zich dus vaak moet onttrekken aan gezinsactiviteiten en andere sociale gebeurtenissen.

Uit tabel 2.2 blijkt verder dat het percentage werkenden dat in ploegendienst werkt ten opzichte van twee jaar geleden licht is gedaald. Bij de sectoren waar twee jaar geleden het percentage werkenden dat in ploegendienst werkte het grootst was is een lichte daling te zien. De sector scheep-en luchtwaart valt echter in negatieve zin op met een toename van 5\%-punt. De sectoren papier en basismetaal blijven de twee sectoren waar ploegendienst het meest voorkomt. Respectievelijk 43 en $40 \%$ van de werkenden in die sectoren werkt in ploegendienst.

Bij de beroepen springen de procesoperators er uit. 67 procent van de procesoperators werkt in ploegendienst. Het verschil met de nummer twee, de brandweerlieden, is bovendien erg groot; 17\%-punt. Opvallend is verder het sterk dalende percentage verpleeghulpen en leerling-verpleegkundigen dat in ploegendienst werkt. Blijkbaar is er sprake van cen veranderend arbeidstijdenregime voor een deel van de werkenden in deze beroepsgroep, waarschijnlijk mede als gevolg van de noodzaak het personeelsverloop af te remmen. Het hoge percentage van de procesoperators dat in ploegendienst werkt weerspiegelt zich in de opleiding MBO procestechniek. Van de werkenden die deze opleiding hebben gevolgd komt bijna de helft terecht in het beroep van procesoperator. Voor vrijwel alle opleidingstypen neemt het percentage werkenden dat in ploegendienst werkzatam is licht af.

is Zir ook tabel 2.20 in de Slatistische Bijlage. 
Tabel 2.2

Bedrijfssectoren, beroepsgroepen en opleidingstypen met het hoogste percentage werkenden dat werkzaam is in ploegendienst, 1996 en 1998

Segment

1998

Bedrijfssectoren

Papier

Basismetaal

Scheep-en luchtwaart

kunststofverwerking

Drank- en tabaksproducten

\section{Beroepen}

Procesoperators

Brandweerlieden

Schippers en conducteurs

Verpleeghulpen en leerling-verpleegkundigen

Asp. politieagenten, soldaten en beveiligingshulpkrachten

\section{Opleidingen}

MBO procestechniek

VMBO beveiliging

MBO vliegtuigtechniek

MBO verpleging

$\mathrm{MBO}$ openbare orde en veiligheid

Bron: CBS/ROA

$\begin{array}{ll}43 & 45 \\ 40 & 49 \\ 38 & 33 \\ 37 & 38 \\ 34 & 39\end{array}$

$67 \quad 68$

$50-$

$49 \quad 50$

$48 \quad 59$

$48 \quad 48$

$\begin{array}{ll}78 & 81 \\ 47 & 53 \\ 47 & - \\ 42 & 41 \\ 35 & 36\end{array}$

\section{$2.4 \mathrm{RSI}$, een verhaal apart}

In deze paragraaf zal wat dieper worden ingegaan op een verzameling van aandoeningen die het gevolg kunnen zijn van belastende arbeidsomstandigheden: RSI (repetitive strain injuries) ${ }^{9}$. In feite bestaat RSI al veel langer dan gedacht wordt. Voordat RSI binnen de arbeidscontext als een belangrijk probleem werd erkend waren in de sportwereld bijvoorbeeld al vele vormen van RSI bekend. De tennisarm, de golfduim en de voetbalknie zijn slechts enkele van de meer bekende aandoeningen, die het gevolg zijn van eenzijdige belasting van een bepaalde spier of spiergroep. Ver daarvoor al zijn echter gevallen bekend van RSI onder middeleeuwse monniken, die leden aan 'schrijfkramp'. Toch is RSI in haar huidige vorm pas sinds kort bekend en er zijn nog voldoende bedrijfsartsen die RSI niet als zodanig herkennen (Popma, 1999).

De ernst van RSI blijkt afhankelijk van een groot aantal factoren:

- de frequentie en snelheid waarmee gelijksoortige bewegingen worden herhaald:

- langdurige statische belasting van bepaalde spieren (tillen);

- extreme houding van het lichaam (boven de macht werken);

9 In de internationale literatuur worden ook andere benamingen aangetroffen voor dezelfe verzameling ziektebeelden bijvoorbeeld: cumulative trauma disorders (CTD), occupational cerwobrachial disorders (OCD), work related musculoskeletal disorders (WMSD). 
- monotonie van het werk;

- de mate waarin werkenden controle hebben over hun eigen werk;

- het aantal opeenvolgende uren dat met een beeldscherm wordt gewerkt;

- de inrichting van de werkplek;

- piekbelasting door bijvoorbeeld deadlines of ziekte van collega's.

In tabel 2.3 is op basis van een tweetal onderzoeken weergegeven binnen welke segmenten op de arbeidsmarkt het percentage werkenden dat het risico loopt met RSI te worden geconfronteerd het grootst is. Uit beide onderzoeken komen de sectoren boreca en bouw naar voren als de sectoren waar het risico van RSI het grootst is. Eerder in het hoofdstuk bleek al dat de werkenden in de sector bouw veel met fysieke belastingsfactoren worden geconfronteerd, met name met trilling. Langdurig werken in dezelfde houding en klachten aan nek, polsen, armen, handen en vingers komen in de sector bouw eveneens relatief vaak voor. In de boreca spelen psychische belastingsfactoren een belangrijke rol. Met name de beperkte beslissingsvrijheid en de hoge werkdruk zorgen voor problemen. In het onderzoek van Otten c.s. wordt overigens ook de werksfeer als mogelijke belastingsfactor opgenomen.

Tabel 2.3

Segmenten op de arbeidsmarkt met het hoogste percentage werkenden dat risico loopt met RSI te worden geconfronteerd

Segment

\section{Bedrijfssectoren}

Horeca*

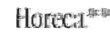

Bouw

Botiwnijverheid**

Landbouw, jacht en bosbouw**

Milieudienstverlening, cultuur, recreatie en overige dienstverlening" ${ }^{\text {* }}$

Vervoer, opslag en communicatie ${ }^{\text {** }}$

\section{Beroepen}

Naai(st)ers"

Metselaars, Limmermannen en bouwvakkers*

Middelbare bouwkundige beroepent"

Laders, lossers en inpakkers*

Lagere algemene transportberoepen*w

Lagere algemeen verzorgende beroepen**

Elementaire beroepen ${ }^{* * *}$

Lagere administratieve beroepen ${ }^{* *}$

* Bron: Blatler en Bongers, 1999

* Bron: Otten, Bongers en Houtman, 1998
$\% \quad$ Type risico

40 kortcyclisch werk, nek, polsen psychosociale risico's; weinig beslissingsvripheid beperkte controle, hoge werkdruk

38 kracht, trilling, langdurig dezelfde houding, nek, polsen, armen, handen en vingers

23 repeterend werk, kracht, trillende apparaten

32 repeterend werk, kracht, sfeer

26 sfeer

24 beperkte controle, regelmatig bovenlichaam in dezelfde houding

cyclisch werk, nek, polsen

nek, polsen, armen

regelmatig kracht zetten, repeterend werk en werken met trillende apparaten

42 cyclisch werk psychosociale risico's; weinig beslissingsvrijheid, hoge baaneisen, weinig sociale steun

27 hoge werkdruk, beperkte controle en regelmatig het bovenlichaam in dezelfde houding

26 geen goede sfeer

23 beperkte controle en werken met trillende apparaten

22 hoge werkdruk, regelmatig bovenlichaam in zelfde houding 
In de sectoren landbouw, jacht en bosbouw en milieudienstverlening, cultuur, recreatie en overige dienstverlening blijkt juist die werksfeer een belangrijke belastingsfactor.

Ook wanneer wordt gekeken naar de beroepen die uit de beide onderzoeken naar voren komen als de beroepen met de grootste RSI risico's, blijkt dat grote verrassingen uitblijven. Het zijn de lagere beroepen die het grootste risico lopen met RSI te maken te krijgen. Naai(st)ers hebben het meest te klagen. Het kortcyclische werk dat zij verrichten lijkt voor klachten aan pols en nek te zorgen.

Metselaars, timmermannen en bouwvakkers scoren wederom hoog. Zij hebben met name klachten aan nek, polsen en armen. Ook laders, lossers en inpakkers behoren tot de risicogroepen, zij het dat zij wat meer last hebben van psychische factoren als een gebrek aan sociale steun en een geringe beslissingsvriịheid.

Noch in het onderzoek van Otten c.s, noch in dat van Blatter en Bongers komen de hogere beroepen naar voren als segmenten waar het risico op RSI groot is. Wel vinden zij dat met name voor werkenden in de hogere beroepen de werkdruk hoog is. Mogelijk speelt werkdruk vooral in combinatie met andere belastende arbeidsomstandigheden een rol van betekenis. Het werken onder hoge druk kan stress veroorzaken. Het is bekend dat stress de spierspanning opvoert, waardoor werknemers extra gevoelig zijn voor fysieke belastingsfactoren (Popma, 1999). Dat geldt bijvoorbeeld voor de lagere algemene transportberoepen waar een hoge werkdruk wordt gecombineerd met een beperkte controle en het werken met het bovenlichaam regelmatig in dezelfde houding. Deze beroepsgroep blijkt hoog te scoren voor wat betreft het risico op RSI. De hoge werkdruk kan er ook toe leiden dat werkenden te weinig rust nemen om het lichaam voldoende te laten ontspannen tijdens computerwerk. Het risico op RSI wordt hierdoor nog verder versterkt.

Tot nog toe is binnen het WSO aandacht besteed aan het toenemend computergebruik als risicofactor voor wat betreft technologische ontwikkeling (zie hoofdstuk 3). Ook als belastende arbeidsomstandigheid wordt het gebruik van computers echter steeds belangrijker, zeker gezien het risico op RSI dat het veelvuldig werken met computers net zich meebrengt. Om het beeld van de risicogroepen op het gebied van de belastende arbeidsomstandigheden compleet te krijgen worden hier alvast de groepen werkenden genoemd die als gevolg van het veelvuldig computergebruik een verhoogd risico lopen dat zij op een bepaald moment als gevolg van RSI hun functie (ten dele) niet meer kunnen uitoefenen

Vooral door grafisch ontuerpers, taalkundigen, organisatiedeskundigen, systeem analisten, informatici en politie-inspecteurs en officieren wordt veel gebruik gemaakt van computers. Het zijn dan ook naar alle waarschijnlijkheid deze beroepen waarin men een relatief hoog risico loopt last te krijgen van RSI. Voor de informatici worden de bestaande risico's nog versterkt door de hoge tijdsdruk. Een gevolg van de hoge tijdsdruk is dat de informatici te weinig ontspanning krijgen, waardoor de symptomen van RSI zich sneller zullen uiten. Enige voorzichtigheid bij de interpretatie van de resultaten is echter geboden. Werkenden in de typische computerberoepen, zoals de informatici, maken over het algemeen gebruik van de nieuwste computers en randapparatuur, warbij bij de ontwikkeling ervan steeds meer aandacht wordt besteed aan ergonomische 
aspecten. Bovendien zijn informatici en bijvoorbeeld systeemanalisten zich waarschijnlijk meer dan andere groepen werkenden bewust van de risico's die zij in hun werk lopen.

\section{RSI}

Inmiddels staat RSI voor alle aandoeningen aan het bewegingsapparaat die ontstaan doordat mensen werken onder belastende arbeidsomstandigheden. Geschat wordt dat er per jaar zo'n twaalfhonderd werknemers als gevolg van RSI in de WAO terechtkomen (Dikker, 1999). Naast het individuele leed dat met de diverse vormen van RSI gepaard gaat kost de uitval uit het werk (ziekteverzuim en WAO) wegens RSI de maatschappij bovendien veel geld. In 1995 bedroegen de maatschappelijke kosten al ruim 9 miljard gulden (Koningsveld en Mossink, 1997). Volgens Dikker (1999) worden nog eens zo'n twee miljoen Nederlanders bedreigd met RSI. Overigens kunnen ook veranderingen in de maatschappij ertoe bijdragen dat RSI zich eerder manifesteert, Zo vergroten flexibilisering, individualisering en ook de combinatie van arbeid en zorgtaken de mentale belasting van werkenden (Van der Linden, 1999).

Inmiddels is er ruime aandacht voor het probleem van RSI. Op het internet bijvoorbeeld worden legio mogelijkheden geboden om tests uit te voeren om te kijken of men een verhoogd risico loopt op RSI (zie ook: www.xs4all.nl/ ulenbelt/rsitest.btml). De overheid heeft zich op het probleem gestort door een CD-ROM te ontwikkelen die beeldschermwerkers moet helpen bij het voorkomen van RSI (www.stoprsi.nl). Ook vindt er steeds meer onderzoek plaats naar de oorzaken en gevolgen van RSI (o.a. Houtman c.s., 1998; Otten c.s., 1998; Blatter en Bongers, 1999). Dit onderzoek heeft onder anderen een beter inzicht verschaft in een aantal nieuwe ziektebeelden, waarvan de 'muisarm' ongetwijfeld de bekendste is. De klachten die leiden tot een muisarm komen overigens niet alleen van het 'muizen' aan de computer, maar kunnen gekoppeld worden aan alle werkzaamheden waarbij gebruik gemaakt wordt van computers of het nu om typen gaat of om tekenen of ontwerpen (CAD). Ten slotte zijn ook vakbonden serieus bezig de risico's in beeld te brengen. FNV Bondgenoten ontwikkelde bijvoorbeeld een zogenaamde beeldschermtachograaf die toetsaanslagen en muisbewegingen registreert gedurende de werktijd, zodat het persoonlijke RSI-risico kan worden bepaald. Vakbonden bieden bovendien op allerlei andere manieren (brochures, workshops e.d.) hulp aan werknemers die blootstaan aan risico's. Ten slotte is er sinds 1994 een vereniging voor RSI patiënten (zie ook: www. ni-vereniging.demon. $n \mathrm{D}$ ).

Met name hoger opgeleiden gebruiken een computer bij het uitvoeren van hun werk. Dit makt dat hoger opgeleiden vrijwel over de gehele linie een belangrijke risicogroep vormen voor wat betreft RSI. Groepen die er nietemin uitspringen zijn werkenden met een opleiding WO informatica en besturlijke informatiekunde, HBO informatica. WO electrotechniek, MBO geld, bank en belastingen of WO werktuigbouwkunde. 


\subsection{Conclusies}

In tabel 2.4 wordt ter completering van dit hoofdstuk een overzicht gegeven van de segmenten van de arbeidsmarkt verbijzonderd naar bedrijfssector, beroep en opleidingstype waar het risico van verlies van werk als gevolg van fysieke of psychische belasting het grootst is.

De bouw is de sector waarin de fysieke belasting het grootst is. Gevolgd door de sectoren veebouderij en metaalproducten. De zware fysieke belasting draagt ertoe bij dat werkenden in de bouw ook een aandachtsgroep zijn voor wat betreft de RSI-risico's.

Beroepen waarin fysieke belasting een belangrijke rol speelt hebben voomamelijk een technische achtergrond (weg- en waterbouwkundige arbeiders, bouwvakkers en metaalarbeiders).

Kijken we ten slotte naar opleidingstype dan zijn het vooral werkenden met een lagere tot middelbare technische opleidingsachtergrond die fysiek zwaar worden belast. Dit zijn overigens ook de opleidingstypen waar ploegendienst als belastingsfactor het meest voorkomt.

De psychische belasting is het grootst bij de beroepen op hoger niveau en in het bijzonder beroepen waarin men te maken heeft met deadlines (journalisten) en strakke tijdschema's (stewards). Ook de informalici werken vaak onder hoge tijdsdruk, mede als gevolg van het tekont aan werkenden in deze beroepsgroep. Hoge tijdsdruk speelt met name een grote rol in de scbeep-en luchtoaart, grafische industrie en het bankwezen. In de eerstgenoemde sector speelt ook het werken in ploegendienst als belastingsfactor een belangrijke rol.

Als naar de opleidingsachtergrond van de werkenden wordt gekeken blijken hoger geschoolden psychisch het zwaarst te worden belast. Afgezien van HBO openbare orde en veiligheid bestaat de lijst met de tien opleidingstypen watr de tijdsdruk het hoogst is louter uit opleidingen op academisch niveau. Werkenden met de opleiding 1 O informatica en bestuurlijke informatiekunde werken het vaakst onder hoge nijdsdruk. Ten slotte moet worden opgemerkt dat hoewel de sector boreca noch op de onderscheiden fysieke belastingsfactoren, noch op psychische belasting hoog scoott, de RSI-risico's in deze sector relatief groot zijn. Blijkbaar speelt in deze sector de combinatie van psychi sche-, psychosociale-en fysieke belasting het sterkst.

Een vergelijking met de resultaten uit de rapportage van 1997 levert een dantal interessante zaken op. Allereerst behoren de sectoren bout-en bouwmateriaten, akkerbouw, bosbout en visserij, reparalie en transportmiddelen niet meer tot de risicogroepen wat betreft fysieke belasting. De sector metaalproducten behoort nu wel tot de risicogroepen. Bovendien blijkt dat er voor de sectoren bout en veebouderij nog te weinig is veranderd om hen uit de risicosfeer te krijgen. Binnen beide sectoren zijn de risicos als gevolg van hoge fysieke belasting nog steeds relatief groot. De beroepen die in 1997 10t de risicogroepen werden gerekend komen ook in deze rapportage weer als zodanig naar voren. Voor opleidingstypen zijn er wel in het oog springende veranderingen. De werkenden met een opleiding VMBO metaal: mechanische techniek behoorden in 1997 
nog niet tot de risicogroepen, waar zij nu de meeste risico's lopen op verlies van werk als gevolg van kwalificatieveroudering door hoge fysieke belasting.

Qua psychische belasting zijn nauwelijks verschillen te zien met 1997. De sectoren scheep-en lucbtvaart, grafische industrie en bankwezen blijven tot de risicogroepen behoren, net als de stewards en de journalisten bij de beroepen. Nieuwe risicogroep voor wat de beroepen betreft is de groep informatici.

De groep werkenden met de opleiding WO informatica en bestuurlijke informatiekunde, in 1997 nog geen risicogroep, staat nu bovenaan de lijst van risicogroepen. De andere opleidingstypen die als risicogroep naar voren komen zijn gelijk aan die in 1997.

\section{Tabel 2.4}

Belangrijkste segmenten die worden geconfronteerd met belastende arbeidsomstandigheden, 1998

\section{Risicodimensie}

Fysiek belastende arbeidsomstandigheden

Bedriffssectoren

Beroepen

Opleidingen

Psychisch belastende arbeidsomstandigheden Bedrijfssectoren

Beroepen

Opleidingen

Ploegendienst

Bedrijfssectoren

Beroepen

Opleidingen

\section{Risicogroep}

\author{
Bouw \\ Veehouderij \\ Metaalproducten
}

Weg- en waterbouwkundige arbeiders Metaalarbeiders Bouwvakkers

VMBO metaal: mechanische techniek MBO motorvertuigentechniek VMBO bouwtechniek

Scheep- en luchtvaart Grafische industrie Bankwezen

Joumalisten

Stewards

Informatici

Wo informatica en bestuurlijke informatiekunde Wo accountancy en belastingen wO (dier)geneeskunde

Papier

Basismetaal

Scheep-en luchtvaart

Procesoperators Brandweerlieden Schippers en conducteurs

MBO procestechniek MBO beveiliging MBO vliegtuigtechniek 
Tabel 2.4 (vervolg)

Belangrijkste segmenten die worden geconfronteerd met belastende arbeidsomstandigheden, 1998

\section{Risicodimensie}

RSII

Bedrijfssectoreys

Beroepen

RSI door computergebruik*

Beroepen

Opleidingen

" zie ook lhooldstuk 3

\section{Risicogroep}

\author{
Horeca \\ Bouwnijverheid \\ Landbouw, jacht en bosbouw
}

Elementaire beroepen

Laders, lossers en inpakkers

Naai(st)ers

Metselaars, timmermannen en bouwvalkers

\author{
Grafische ontwerpers \\ Taalkundigen \\ Organisatiedeskundigen \\ Systeemanalisten \\ Informatici
}

Wo informatica en bestuurlijke

informatiekunde

HBO informatica

Wo elektrotechniek

MBO geld, bank en belastingen

wo werktuigbouwkunde

Opvallend is verder dat werkenden met $H B O$ civiele techniek en HBO communicatie en journalistiek niet langer tot de belangrijkste risicogroepen behoren. Voor deze groepen werkenden is het percentage werkenden dat onder hoge tijdsdruk werkt dan ook aanzienlijk gedaald. met respectievelijk 21 - en $9 \%$-punt. 


\section{Technologische en organisatorische ontwikkelingen}

\subsection{Inleiding}

Technologische ontwikkelingen

De komst van nieuwe machines, automatisering en informatisering, globalisering, op de consument afgestemd maatwerk, het toenemend belang van de kwaliteit van de geleverde goederen en diensten en een 24-uurs economie; allemaal ontwikkelingen die aan bedrijven en organisaties legio mogelijkheden bieden om sneller, efficiënter en effectiever te opereren. Meegaan met deze ontwikkelingen en liefst vooroplopen is immers datgene waar het in de bedrijfsvoering on gaat. Het werken met meer efficiënte machines of een betere computerondersteuning stelt een bedrijf in staat de prijs-kwaliteit-verhouding te verbeteren, waardoor de concurrentiepositie kan worden versterkt. Nieuwe technologieën stellen echter nieuwe eisen aan de mensen die enmee moeien werken. Volgens Miles en Ducatel (1994) kunnen technologische ontwikkelingen een drietal effecten sorteren.

Allereerst kan er sprake zijn van downgrading. Dat wil zeggen dat bepaalde kwalificaties als gevolg van de technologische ontwikkeling minder waard worden c.q. verouderen. Een voorbeeld is de ontwikkeling en implementatie van boekhoudkundige software, die ervoor zorgt dat het handmatig kunnen boekhouden en de bijbehorende rekenvaardigheden minder waard worden.

Een nieuwe technologie kan ook een omgekeerd effect hebben en juist bepaalde vaardigheden in waarde doen stijgen. Het overgaan van machine A naar de snellere machine $\mathrm{B}$ kan de latente vaardigheden van bepaalde werkenden aan de oppervlakte brengen. Hun kwalificaties winnen hierdoor aan waarde. Ook het gegeven dat snelle technologische vooruitgang werkenden een bepaalde mate van flexibiliteit oplegt leidt vaak tot een zekere upgrading van de kwalificaties, waarover men dient te beschikken.

Een derde mogelijkheid is dat technologische vooruitgang zorgt voor een polarisatie van de op de arbeidsmarkt vereiste kwalificaties. Technologische vooruitgang zorgt er in deze optiek voor dat de banen op middenmanagement niveau worden weg-geautomatiseerd, waardoor enerzijds de manuele en fysieke arbeid op het laagste niveau en anderzijds de kennis-intensieve banen op het hoogste niveau resteren.

In alle gevallen komen de effecten van technologische ontwikkelingen echter neer op wijzigingen in de organisatie van het werk en veranderingen van functie-eisen, zoals die aan werkenden worden gesteld. Naarmate technologische ontwikkelingen een grotere rol spelen, zijn werkenden dus automatisch kwetsbaarder, omdat hun kwalificaties sneller verouderen.De ontwikkelingen op de arbeidsmarkt wijzen in het algemeen in de richting van een upgrading van het vereiste kwalificatieniveau (zie bv. ROA, 1999). Uit internationaal onderzoek komt naar voren dat deze upgrading in belangrijke mate het gevolg is van technologische ontwikkelingen (zie bv. Machin, Ryan en Van Reenen, 1996 ). 
Niet elk segment van de arbeidsmarkt heeft in even grote mate met technologische ontwikkelingen te maken, waardoor de gevaren van kwalificatieveroudering niet voor elke groep werkenden in dezelfde mate aanwezig zijn. In dit hoofdstuk wordt onderzocht op welke segmenten van de arbeidsmarkt de veranderingen op technologisch vlak het grootst zijn.

\section{Research \& Development}

Bij de analyse van technologische ontwikkelingen staan allereerst de investeringen in research and development (R\&D) centraal. R\&D heeft betrekking op zowel fundamenteel als toegepast onderzoek. Daarnaast wordt ook ontwikkelingswerk tot R\&D gerekend. Dit ontwikkelingswerk omvat alle activiteiten die erop gericht zijn de resultaten van onderzoek te gebruiken voor de totstandbrenging van nieuwe of aanzienlijk verbeterde producten, materialen, processen of systemen of van nieuwe toepassingsmogelijkheden ervan (Brouwer en Kleinknecht, 1994). Er bestaat grote eensgezindheid over het belang van investeringen in R\&D, menselijk kapitaal en kennis-infrastructuur voor technologische innovatie (Brouwer en Kleinknecht, 1993). Hierbij zijn gegevens over de investeringen in R\&D de meest gebruikte gegevens bij studies naar technologische innovaties (zie bv. Van Hulst en Soete, 1989 en Kleinknecht en Verspagen, 1990).

Om de ontwikkelingen op het gebied van R\&D in beeld te brengen is een index gecreëerd, die wordt verbijzonderd naar bedrijfsgrootte en bedrijfssector. Deze R\&D index is gebaseerd op een viertal kengetallen ${ }^{10}$, namelijk:

- bedrijven met R\&D

- gemiddelde omvang R\&D

- R\&D voor vernieuwing producten en/of diensten

- R\&D voor vernieuwing productieprocessen

\section{Informatie en Communicatie Technologie}

Behalve ontwikkelingen op het gebied van R\&D zijn ook de vernieuwingen op informatie- en communicatietechnologisch gebied van groot belang. De ontwikkelingen op dit vlak worden in beeld gebracht door te kijken naar de actuele stand van zaken op het terrein van de bedriffsautomatisering. Hiertoe is een ICT (Informatie en Communicatie Technologie)- index ontwikkeld, die wordt verbijzonderd naar bedriffsgrootte en bedriffssector. Deze ICT-index is gebaseerd op een viertal kengetallen ${ }^{11}$, te weten;

- automatiseringsgraad;

arbeidsjaren automatiseringspersoneel;

- automatiseringskosten per werknemer;

- percentage bedrijven dat zowel gebruiker als aanbieder is op het internet.

$10 \mathrm{De}$ index is een ongewogen combinatie van de vier kengetallen. In de Statistische Bijlage is voor elk van deze afzonderlijke kengetallen een tabel opgenomen.

11 Ook hier gat het om een ongewogen index. In de Statistische Bijlage is van elk van de afzonderlijke kengetallen eetr aparte tabel opgenomen. 


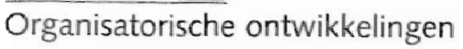

De vele ontwikkelingen op technologisch vlak impliceren vaak ook een grondige revisie van de strategie van organisaties. Het feit dat technologische ontwikkelingen elkaar snel opvolgen draagt ertoe bij dat organisaties hun structuur steeds meer opzetten vanuit een groeiende behoefte aan flexibiliteit. Deze herformulering van de organisatiestrategie brengt veel veranderingen met zich mee, variërend van kleine vernieuwingen in het producten- en dienstenpakket tot grote reorganisaties. Al deze veranderingen eisen een zeer flexibele houding van werkenden. Wanneer werkenden niet over een dergelijke houding beschikken dan kan het voor hen moeilijk worden zich staande te houden binnen de organisatie.

Niet alleen als gevolg van technologische ontwikkelingen verandert de organisatie; ook internationalisering heeft vaak vergaande consequenties voor de bedrijfsvoering. De toenemende buitenlandse concurrentie wordt steeds beter voelbaar en raakt inmiddels de meeste bedriffssectoren. Een van de gevolgen van deze toenemende concurrentie is dat steeds meer bedrijven hun marktpositie trachten te verbeteren door samen te werken met buitenlandse partners. Het aantal grensoverschrijdende fusies, afspraken, joint ventures en overnames neemt het laatste decennium fors toe (Van der Hoeven c.s., 1997).

Uit onderzoek van Kleinknecht en Oostendorp (1998) blijkt dat internationaal georiënteerde bedrijven meer gebruik maken van uitzendkrachten. De baanzekerheid lijkt in de internationaal georiënteerde organisaties dus wat minder groot dan in bedrijven die zich richten op een nationale of regionale afzetmarkt. Internationalisering leidt meestal tot organisatorische aanpassingen, die in omvang en snelheid weliswaar van elkaar verschillen maar allen hun directe invloed hebben op de kwalificatie-eisen die aan werkenden worden gesteld.

Om de organisatorische ontwikkelingen in beeld te brengen is een derde index gecreëerd, die wordt verbijzonderd naar bedrijfsgrootte en bedrijfssector. Ook deze index is gebaseerd op vier kengetallen met betrekking tot het belang van ${ }^{12}$;

- kleine vernieuwingen in het producten- en dienstenpakket;

- ingrijpende vernieuwingen in het producten- en dienstenpakket;

- verandering van de positie van de organisatie;

interne reorganisaties.

\section{Organisatieveranderingen en competentie-ontwikkeling in de praktijk}

In 1999 is door ROA een onderzoek uitgevoerd naar de betekenis van de veranderingen in een organisatie voor de competenties en het functioneren van de medewerkers. Het onderzoek is uitgevoerd binnen een van de grotere bedrijven in de Nederlandse financiële dienstverlening. Een honderdtal medewerkers en hun managers zijn voor het onderzoek geënquêteerd. Bovendien is met een aantal directeuren en HRM-medewerkers gesproken.

12 In de Statistische Bijlage is voor elk van de afzonderlijke kengetallen een tabel opgenomen 
Uit het onderzoek komt naar voren dat de veranderende regelgeving, de introductie van nieuwe computersystemen en expliciete en impliciete organisatorische veranderingen in de perceptie van de medewerkers de belangrijkste veranderingen zijn geweest. Slechts een klein deel van de medewerkers zegt problemen te hebben zich aan de veranderingen aan te passen. De problemen die er spelen waren het grootst bij de organisatorische veranderingen. Ondanks de royale steun van de kant van de organisatie om de veranderingsprocessen probleemloos te laten verlopen zijn veel medewerkers toch van mening dat het aanpassingsproces beter had kunnen verlopen als er nog meer ondersteuning was geweest. Bovendien blijkt dat de nieuwe competenties, die nodig zijn om het aanpassingsproces goed te laten verlopen, lang niet altijd alleen verworven zijn in cursussen, maar ook door werkervaring en bij collega's. Deze factoren leiden tot een van de belangrijkste conclusies van het onderzoek, namelijk dat de aard van de cursussen en de inhoud ervan mogelijk onvoldoende aansluit bij de problemen die werknemers ondervinden bij de aanpassingsprocessen die zij moeten doorlopen. Kennelijk is het moeilijk om op centraal niveau vast te stellen hoe aanpassingsprocessen het beste kunnen worden ondersteund en hoe de competentieontwikkeling en het beleid dat daarop is gericht het beste kan worden vormgegeven.

Opmerkelijk is overigens dat hoewel medewerkers niet vaak aangeven hun competenties in een cursus te hebben verworven zij wel van oordeel zijn dat ze nieuwe competenties het beste in een cursussetting zouden kunnen verwerven. Dit betekent dat de cursussen die tot nu toe werden gegeven onvoldoende aansloten op de behoefte van de medewerkers of dat ook medewerkers de mogelijke effecten van cursussen overschatten. Cursussen zullen dus meer toegespitst moeten worden op de specifieke behoefte van de medewerker of de werkplek zelf zou beter benut moeten worden als een leerrijke werkomgeving.

Om de competentie-ontwikkeling van medewerkers te bevorderen, is het daarom van belang dat keuzes en verantwoordelijkheden met betrekking tot het leerproces meer vanuit het individu worden genomen. Een aantal factoren bemoeilijkt echter de implementatie van een nieuwe verantwoordelijkheidsstructuur, zo blijkt uit het onderzoek. Allereerst ontbreekt het aan een helder beeld van aanwezige competenties, zowel bij managers als bij medewerkers. Een helder beeld over de sterke en zwakke punten van iedere medewerker lijkt echter een basisvoorwaarde voor een adequate verdere competentie-ontwikkeling.

Een tweede drempel bij het invoeren van een nieuwe verantwoordelijkheidsstructuur is dat medewerkers zelf nog slechts in beperkte mate de verantwoordelijkheid voor de eigen ontwikkeling nemen. Men voelt zich bij de huidige werkgever uitermate veilig, men heeft niet de wens om zelf te investeren in opleidingen en de eigen loopbaan en men is zich nauwelijks bewust van informele leerprocessen. De beloningsstructuur en de werkzekerheid die de organisatie biedt, blijken nauwelijks samen te hangen met de competenties waarover mensen beschikken.

Ten slotte is de rol van de organisatie bij het ondersteunen van een beleid dat erop gericht is de medewerkers steeds meer zelf de verantwoordelijkheid te laten nemen voor de eigen loopbaan vooralsnog onvoldoende ontwikkeld. De organisatie zou 
zich moeten richten op cursussen die beter aansluiten bij de problemen die medewerkers ondervinden bij de aanpassing aan veranderingen in hun werkomgeving. Bovendien is er een tak voor de organisatie weggelegd voor wat betreft het creëren van een leerrijke werkomgeving, bijvoorbeeld bij de verdeling van werkzaamheden over medewerkers en de samenstelling van teams.

Uit het onderzoek bleek ook dat oudere en jongere medewerkers niet gelijkmatig zijn verdeeld over de afdelingen. Op de ene afdeling werken bijvoorbeeld veel ouderen en op de andere afdeling, die dezelfde werkzaamheden verrichten, werken veel jongeren. Dit is niet bevorderlijk voor de ervaringsoverdracht van ouderen op jongeren, maar ook kennisoverdracht van jongeren op ouderen op bijvoorbeeld het gebied van computergebruik wordt hierdoor bemoeilijkt.

Bron: Borghans, L. et al., (2000) Organisatieveranderingen en competentie-ontwikkeling; Verslag van een enquête bij Het Kantoor; ROA-R-2000/3, Maastricht.

\section{Computergebruik naar beroep en opleiding}

De ontwikkelingen op ICT gebied hebben een belangrijke invloed op de veroudering van kwalificaties doordat het juist deze ontwikkelingen zijn die ervoor zorgen dat het gebruik van computers op de werkplek almaar toeneemt. Een sprekend voorbeeld van kwalificatieveroudering als gevolg van computerisering komt uit de banksector, waar het beroep van data-typist inmiddels nagenoeg is verdwenen, doordat de verwerking van schriftelijke betalingsopdrachten volledig geautomatiseerd is (De Grip en Groot, 1990; Stroeken, 1993). Zowel het verdwijnen van bepaalde functiegebieden als de inhoudelijke verandering van de werkzaamheden in een veel groter aantal functies is een gevolg van de voortgaande computerisering. Waar relatief veel met computers wordt gewerkt bestaan dus belangrijke risico's op verlies van werk vanwege kwalificatieveroudering.

\section{Opzet hoofdstuk}

In paragraaf 3.2 zullen allereerst enkele algemene automatiseringskengetallen en trends worden toegelicht, waarna in de paragrafen 3.3 tot en met 3.5 aln de hand van een aantal indices een actueel beeld wordt gegeven van de R\&D-, ICT-en organisatorische ont wikkelingen naar bedrijfssector en bedriffsgrootte. Ook wordt in elk van deze paragrat fen getracht de bedrifssectoren te onderscheiden warin de gevolgen van bepaalde ontwikkelingen mogelijk cumuleren. Zo wordt aangegeven in welke sectoren veel ontwik kelingen op het gebied van R\&D of ICT samenvallen met veel organisatorische veranderingen. Ook wordt in paragraaf 3.4 gekeken in hoeverre bedrijfssectoren die wat achterlopen op het gebied van ICT bezig zijn met een inhaalslag. Aan de hand van gegevens omtrent het gebruik van computers wordt vervolgens in paragraf 3.6 in kart gebracht in welke beroepen en opleidingstypen men als gevolg van de computerisering van het werk een verhoogd risico loopt vanwege het verouderen van kwalificaties het werk te verliezen. In paragraaf 3.7 wordt ten slotte een integraal overzicht gegeven van de groepen werkenden die een verhoogd risico lopen hun werk te verliezen als gevolg van snelle technologische en organisatorische ontwikkelingen. 


\subsection{Enkele kengetallen}

In de particuliere sector werd in 1997 in totaal ruim $f 23$ miljard aan automatisering uitgegeven. Dat is zo'n f5 miljard meer dan in 1994. De automatiseringskosten stijgen overigens al geruime tijd onafgebroken. In drie jaar tijd zijn de uitgaven gemiddeld met ruim $10 \%$ gestegen. Het is zeer waarschijnlijk dat het millenniumprobleem daarvoor mede verantwoordelijk was. Zo'n 7\% van de totale IT uitgaven houdt verband met het millenniumprobleem (Smit, 1999). Niet alleen reparatie van bestaande systemen, maar ook de vervroegde aanschaf van nieuwe applicaties en hardware stuwen de automatiseringsuitgaven verder op. Voor de toekomst verwachten bedrijven overigens niet minder uit te gaan geven aan automatisering. Verwacht wordt dat in 1999 ruim $f 27$ miljard aan automatisering wordt uitgegeven, een stijging van een kleine $f 4$ miljard in 2 jaar tijd.

Figuur 3.1

Procentuele opbouw automatiseringskosten, 1997

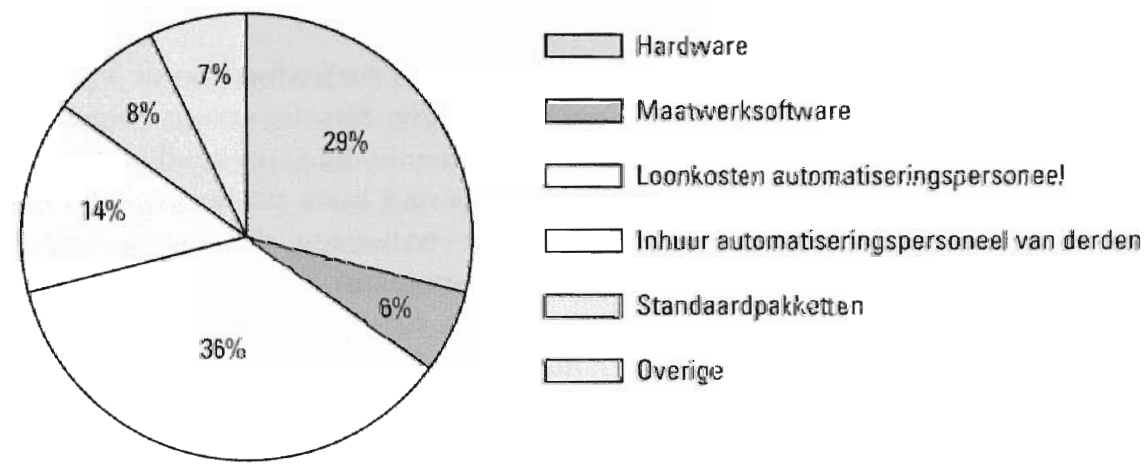

Bron: CBS/ROA

Wit een nadere analyse van de opbouw van de automatiseringskosten, figuur 3.1, en een vergelijking van deze cijfers met die van 1994, blijkt dat met name de inhuur van automatiseringspersoneel van derden een steeds belangrijkere kostenpost wordt. In 1997 werd 14\% van de totale automatiseringskosten besteed aan inhuur van extern automatiseringspersoneel, in guldens is dat ruim $f 3$ miljard. In 1994 was dat nog slechts $8 \%$, zo n $f 1,5$ miljard. Het grootste deel van de automatiseringskosten, 36\%, wordt nog steeds gespendeed a tan lonen voor automatiseringspersoneel. 29 Procent van de totale automatiseringskosten gaat naar hardware, $14 \%$ naar software.

In liguur 3.2 wordt een beeld geschetst van de ontwikkeling van de vier kengetallen, zoals die later in het hoofdstuk zullen worden gebruikt on de ICT-index te creëren. Als basisjaar geldt 1993. Vit de figuur blijkt dat de automatiseringsgraad vrij constant is gebleven. In 1997 was 75\% van alle bedrijven geautomatiseerd. Het aantal arbeidsjaren atumatiseringspersoneel is sinds 1995 weer aan het toenemen en vooral in 1997 is 
sprake van een forse stijging van ruim 15\%-punt. Dat meer wordt uitgegeven aan automatiseringspersoneel bleek ook al uit figuur 3.1. Waarschijnlijk is derhalve dat in veel bedrijven de millenniumbug aanleiding is geweest om extra personeel in te zetten voor de doorlichting van systemen. Voor de nabije toekomst wordt verwacht dat de uitgaven aan automatiseringspersoneel zeker niet zullen dalen, omdat veel projecten als gevolg van de millenniumproblematiek zijn blijven liggen (Smit, 1999). Ook de automatiseringskosten per werknemer zijn het laatste jaar gestegen met ruim 20\%-punt.

Figuur 3.2

Enkele kengetallen en de ontwikkeling ervan in de tijd $(1993=100)^{*}, 1993-1997$

Indices $(1993=100)$
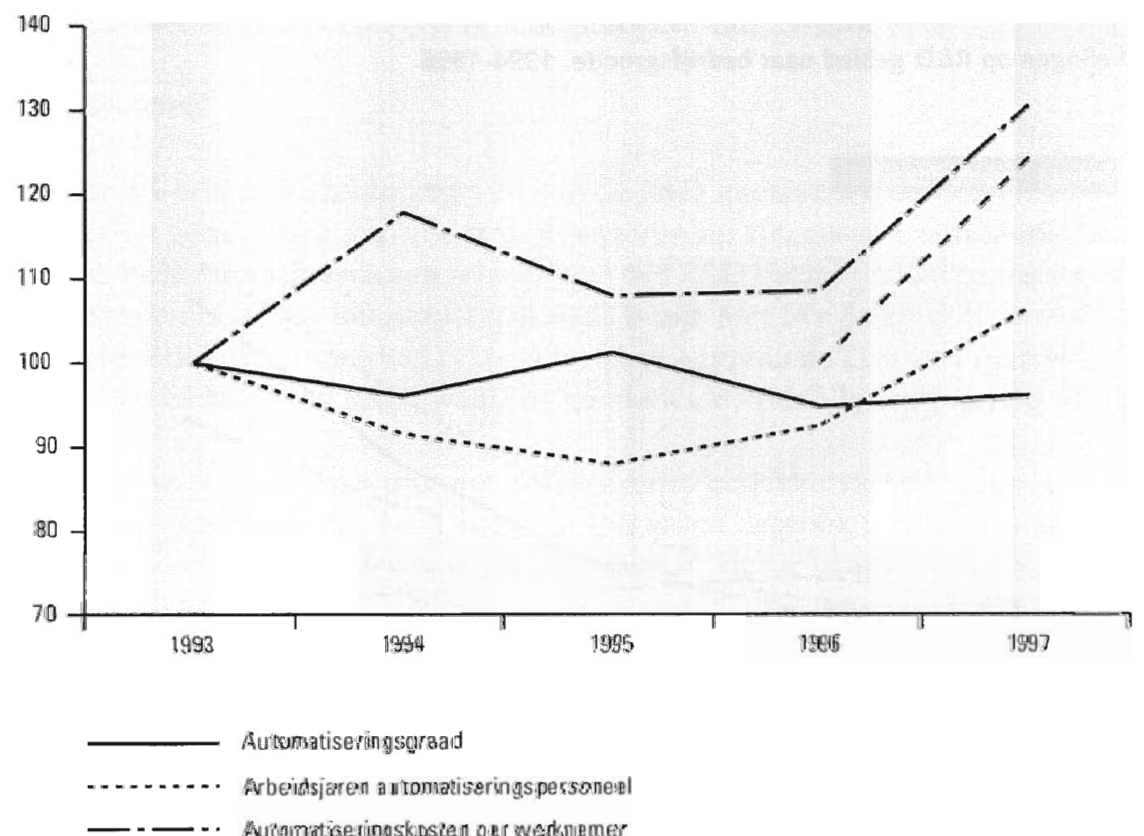

- - - - Gebruiker èn aanbieder op het internet

\footnotetext{
* Voor de variabele gebruiker èn aanbieder internet geldt dat $1996=100$ Bron: CBS/ROA
}

In figuur 3.2 wordt ten slotte nog gekeken naar de ontwikkeling van het percentage bedrijven dat zowel als gebruiker als als aanbieder het internet benut. Dit om een idee te krijgen van het internetgebruik in Nederlandse organisaties. 
Uit de figuur blijkt dat het gebruik van internet snel toeneemt. Was in 1996 nog $41 \%$ van de bedrijven met een internetaansluiting zowel gebruiker als aanbieder, in 1997 is dat percentage gestegen naar 51\%. In 1999 verwacht 60\% zowel aanbieder als gebruiker te zijn op het internet. Het toenemende gebruik van internet blijkt verder uit de forse stijging van het percentage geautomatiseerde bedrijven dat internet gebruikt. Eind 1997 maakte $34 \%$ van de geautomatiseerde bedrijven gebruik van internet. Voor het eind van 1999 zal bijna de helft van de geautomatiseerde bedrijven internet gebruiken (CBS, 1999).

\subsection{Ontwikkelingen op het gebied van Research \& Development}

\section{Bedrijfsgrootte}

In Werkgelegenbeid en scholing 1997 werd duidelijk dat grotere bedrijven in 1994 meer aan R\&D hebben gedaan dan kleinere bedrijven.

Figuur 3.3

Ontwikkelingen op R\&D gebied naar bedrijfsgrootte, 1994-1996

Indices (gemiddelde $=100$ )

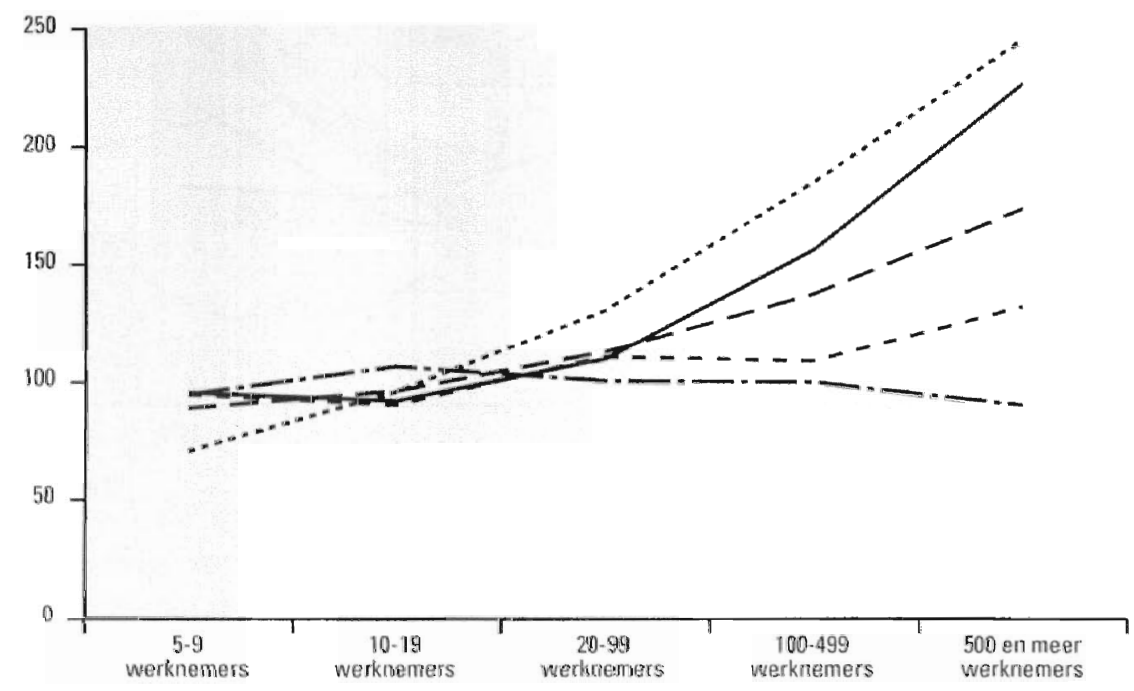

Bedrifisgroatte

Gemiddelde omvang R\&D

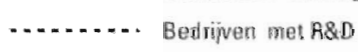

- - - R\&D woor vernieuwing producten/diensten

- - - - R\&D voor vernieuwing productieprocessen

- - R\&D Index

Bron: OSVROA 
De stijgende lijn die de R\&D Index ${ }^{13}$ in figuur 3.3 laat zien maakt duidelijk dat dat in 1996 niet anders was. Daarbij komt dat de verschillen tussen grote en kleine bedrijven groter zijn geworden. Het percentage bedrijven met R\&D bijvoorbeeld is voor middelgrote en kleine bedrijven (tot 100 werknemers) ten opzichte van 1994 met ongeveer 2\%punt gestegen tot $21 \%$. Voor grote bedrijven (500 en meer werknemers) is die stijging $13 \%$-punt, van $62 \%$ naar $75 \%$.

Tevens opvallend is de forse toename van het deel van de totale R\&D kosten dat aan vernieuwing van producten en diensten wordt gespendeerd. In 1994 werd nog 40\% van de totale R\&D uitgaven gespendeerd aan vernieuwing van producten en diensten, in 1996 is dat 59\%. Overigens blijkt het wat dit percentage betreft niet veel uit te maken hoe groot een bedrijf is. De kleine bedrijven (5-9 werknemers) spenderen 55\% van hun totale R\&D uitgaven aan vernieuwing van producten en diensten. De grootste bedrijven (500 en meer werknemers) 53\%. De gemiddelde omvang van R\&D als percentage van de omzet is in de afgelopen jaren wat gedaald. Gemiddeld besteedden bedrijven in 1996 zo'n 3\% van de omzet aan R\&D. In 1994 was dat iets meer dan 4\%. Het percentage bedrijven met R\&D daarentegen is licht gestegen, van $29 \%$ tot $31 \%$.

\section{Bedrijfssectoren}

In figuur 3.4 is een overzicht gegeven van de R\&D intensiteit naar bedrijfssector ${ }^{14}$. In de figuur is het gemiddelde van alle bedrijfssectoren op 100 gesteld, waardoor gemakkelijk te zien is welke bedrijfssectoren relatief veel met R\&D bezig zijn. De bedrijfssector kwartaire diensten blijkt het intensiefst met R\&D bezig. Met $54 \%$ heeft deze sector het grootste aandeel bedrijven met R\&D. Daarbij wordt gemiddeld $11 \%$ van de totale omzet in deze sector besteed aan R\&D, waar het gemiddelde voor alle sectoren op $3 \%$ ligt.

Ook in de sector chemie wordt een relatief groot gedeelte van de totale omzet in R\&D gestoken, 6\%. Deze sector is na kwartaire diensten dan ook het meest met R\&D bezig. De sector overbeid en onderwis is de sector op de derde plaats waar het gaat om R\&Dintensiteit. Dit heeft waarschijnlijk alles te maken met het feit dat de wetenschappelijke onderzoeksbureaus binnen deze bedrijfssector vallen. Veel van deze bureaus kennen R\&D als kernactiviteit en worden bovendien door andere bedrijven ingehuurd om onderzoek te verrichten. Overheid en onderwijs is overigens de enige sector watr meer geld wordt besteed aan de vernieuwing van productieprocessen dan aan de vernieuwing van producten en diensten.

13 Zie ook tabellen $3.5 \mathrm{en} 3.6$ in de Statistische Bijlage.

14 Zie ook tabellen 3.14 en 3.15 in de Statistische Bijlage. 
Wanneer een vergelijking met de cijfers van de vorige rapportage wordt gemaakt valt een aantal zaken op. Allereerst dat in nagenoeg alle bedrijfssectoren de gemiddelde omvang van R\&D is gedaald. In de sectoren landbouw en visserif, voeding en metaal en elektrotecbniek was die daling het grootst. In 1996 werd in die sectoren 5\%-punt minder van de omzet aan R\&D besteed dan in 1994. Enkel in de sectoren boreca en zakelijke dienstverlening en overige industrie neemt de gemiddelde omvang van de R\&D uitgaven toe, met respectievelijk 2 en 1\%-punt. Ten tweede valt de aanzienlijke daling van het percentage bedrijven met R\&D in de sector chemie op. In 1994 deed 68\% in deze sector nog aan R\&D. In 1996 was dat nog maar 45\%. Ook in de sector landbouw en visserij is sprake van een behoorlijke daling van het percentage bedrijven met R\&D, 10\%-punt. In de sectoren kwartaire dicnsten en boreca en zakelijke dienstverlening stijgt het percentage bedrijven met R\&D daarentegen met respectievelijk 9- en 8\%-punt.

\section{Figuur 3.4}

\section{Ontwikkelingen op R\&D gebied naar bedrijfssector, 1994-1996}

\section{Indiees (gemiddelde $=100$ )}

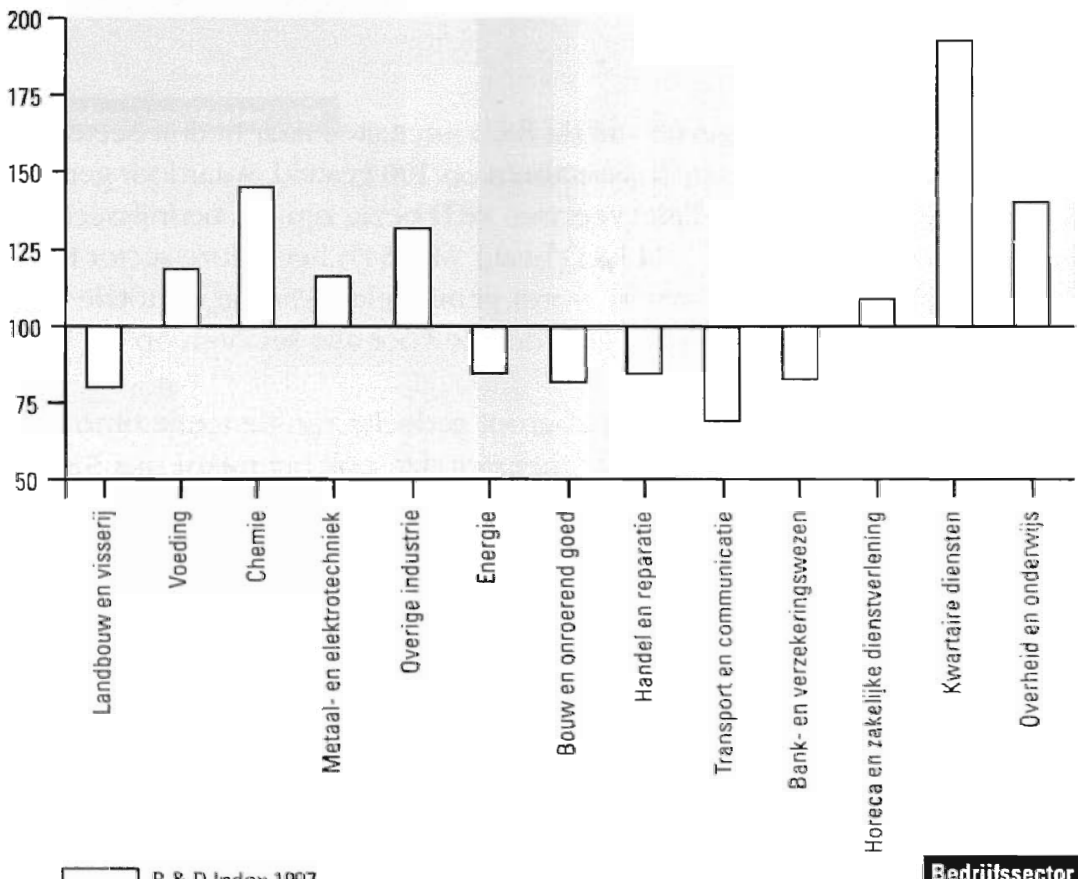

Bron: OSNROA

Ten slotte is het opmerkelijk dat het aandeel van de R\&D uitgaven voor vernieuwing van producten en diensten in de sector bank-en verzekeringstuzen scherp daalt en het deel van de totale uitgaven dat aan de vernieuwing van productieprocessen wordt besteed in dezelfde sector fors toeneemt. In het bank-en verzekeringsuezen wordt warschijnlijk veel geünesteerd in netwerksystemen die het mogelijk maken informatie nog sneller en beter door te spelen. 


\subsection{Informatie- en communicatietechnologie}

Om inzicht te krijgen in de ontwikkelingen op het gebied van de informatie- en communicatietechnologie (ICT) wordt uitgegaan van prognoses van bestaande bedrijven. Op basis van de prognoses voor 1999 en de actuele stand van zaken in 1997 is een index opgesteld waarmee de ICT-ontwikkelingen worden weergegeven. 1997 geldt hierbij als basisjaar en is derhalve op 100 gesteld. Aldus blijkt dat voor elk segment van de arbeidsmarkt sprake is van een toename van het gebruik van informatie en communicatietechnologie.

\section{Bedrijfsgrootte}

Uit figur 3.5 is op te maken dat de ontwikkelingen op ICT" gebied in het midden- en kleinbedrijf sneller gaan dan in grotere bedrijven ${ }^{15}$. Wel ligt het niveau van de ICTtoepassingen in het midden- en kleinbedrijf nog steeds een stuk lager dan in de grotere bedrijven. Van de allergrootste bedrijven ( 500 of meer werknemers) is $97 \%$ geautomatiseerd, van de middenbedrijven (20-99 werknemers) is dat $89 \%$ en van de kleinste bedrijven (5-9 werknemers) nog slechts $66 \%$.

Figuur 3.5

ICT-ontwikkeling naar bedrijfsgrootte, 1997-1999

\section{Bedrijfsgrootte}

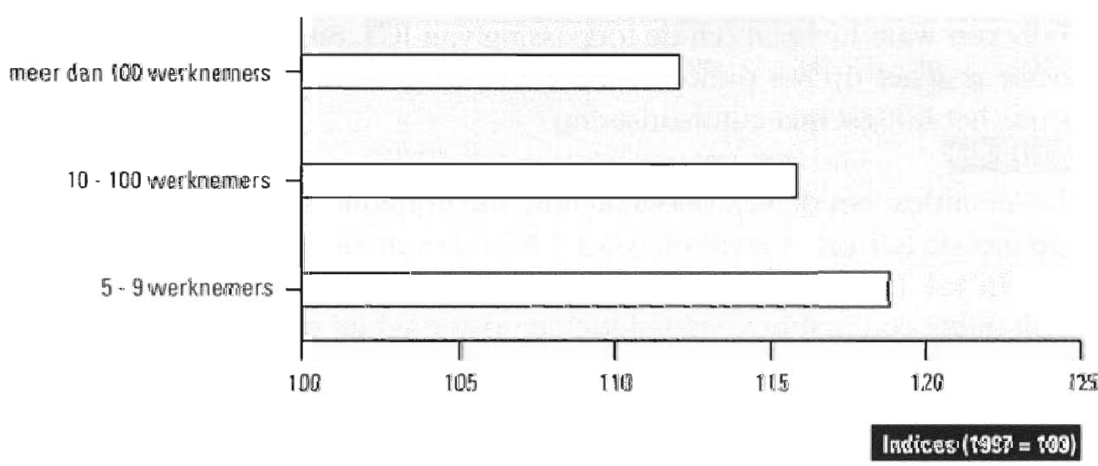

ICT Ontwikkelingsindex 1997-1999

Bron: CBS/ROA

Ook de automatiseringskosten per werkplek nemen toe naarmate een bedrijf groter is; in de kleine bedrijven wordt per werkplek $f 4.000$ gulden uitgegeven, in het middenbedrijf $f 8.000$ en in het groothedrijf zelfs $f 19.000$ per werkplek. Ook het percentage bedrijven met automatiseringspersoneel en het percentage geautomatiseerde bedrijven dat zowel als a anbieder als als gebruiker het internet gebruikt groeit naarmate de bedriffsgrootte toeneemt. Uit de diverse cijfers blijkt dat het midden- en kleinbedrijf duidelijk bezig is met een inhaalslag op het gebied van ICT toepassingen.

15 Zie ook tabellen 3.1 tot en met 3.4 in de Statistiscbe Bijlage. 
Het wekt geen verbazing dat ICT ontwikkelingen een grotere rol spelen in grote bedrijven, aangezien grotere bedrijven nu eenmaal meer kapitaal vrij kunnen maken en/of aan kunnen trekken om te investeren in ICT-toepassingen. Daarbij komt dat binnen kleinere bedrijven ook minder behoefte bestaat aan uitgebreide computernetwerken en dergelijke, omdat de meeste communicatie direct verloopt. Dat sprake is van een inhaalslag door het midden- en kleinbedrijf geeft echter wel aan dat de behoefte aan moderne ICT-toepassingen ook binnen het midden- en kleinbedrijf groter wordt.

\section{Bedrijfssectoren}

In figuur 3.6 wordt een overzicht gegeven van de verwachte ontwikkelingen op ICT gebied per bedrijfssector ${ }^{16}$. Met name de vlotte ontwikkelingen in de sector voeding vallen op. In 1997 scoorde deze sector op de meeste kengetallen overigens gemiddeld tot laag. 72 Procent van de bedrijven is geautomatiseerd, $11 \%$ heeft automatiseringspersoneel in dienst en slechts $4 \%$ van de geautomatiseerde bedrijven is op het internet actief als gebruiker en aanbieder. Ook de automatiseringskosten per werkplek zijn met f11.000 niet opvallend hoog te noemen. In 1999 verwachten de bedrijven in de sector voeding met name een toename van het aantal arbeidsjaren automatiseringspersoneel en een forse stijging van het percentage bedrijven dat het internet zowel als aanbieder als alls gebruiker zal gaan benutten. Het lijkt er derhalve op dat de sector voeding bezig is met een inhaalslag.

Ook in de sector cbemie verwacht men veel ontwikkelingen op ICT gebied. Een belangrijk verschil met de sector voeding is echter dat bedrijven in de sector chemie al tot de voorhoede behoren waar het gaat om de toepassing van ICT. 88 Procent van de bedrijven in de sector is actief op het punt van automatisering. Na de sector energie scoort chemie daarmee het hoogst qua automatisering.

In figuur 3.7 is de index van de ICT ontwikkeling, die in figuur 3.6 werd gepresenteerd gecombineerd met de ICT index zoals die voor 1997 is berekend. De figur is opgedeeld in vier vakken. In vak I zitten die bedrijfssectoren die bezig zijn met een inhaalslag op ICT gebied. Dit impliceert een bovengemiddelde positie op de ontwikkelingsindex en een benedengemiddelde score op de ICT index van 1997. Met name de sector voeding blijkt met een inhaalslag bezig. Andere bedrijfssectoren in vak I zijn landbouw en visserij, metaal- en elektrotechniek, bouw en onroerend goed en handel en reparatie. Het zijn warschijnlijk deze sectoren waar het meest gevreesd moet worden voor veroudering van kwalificaties, doordat veel werkenden in korte tijd met de snelle ontwikkelingen mee zullen mocten.

In vak II bevinden zich de bedrijfssectoren waarin de toepassing van ICT reeds op een relatief hoog niveau ligt. Bovendien is er in deze sectoren sprake van relatief snelle ontwikkelingen op het gebied van de ICT. Vak II herbergt dus die sectoren die voorlopig vootop blijven lopen voor wat betreft het gebruik van ICT toepassingen. De bedriffssector chemie is de enige sector die zich in vak If bevindt. De risico's van kwalificatieveroudering voor de werkenden in de sectoren in dit vak zijn groot. Toch zijn de risico's van de werkenden in de sectoren in vak I waarschijnlijk groter. De werkenden in de sec-

16 Zie ook de tabellen 3.10 tot en met 3.15 in de Statisfixibe Bijlage. 


\section{Bedrifissector}

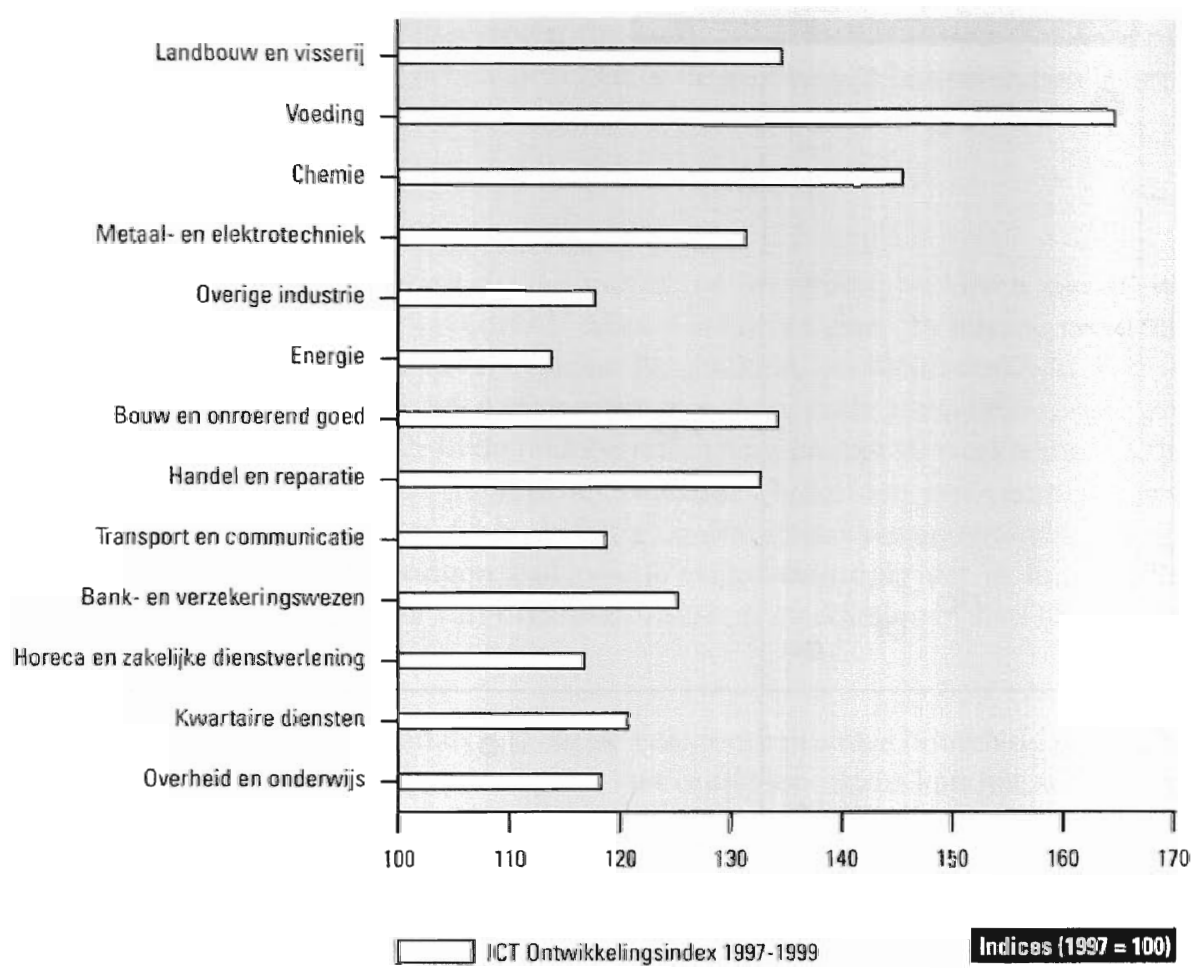

Bron: CBS/ROA

toren die vooroplopen zijn immers gewend aan de snelle ontwikkelingen op ICT gebied. Dit maakt hen waarschijnlijk weetbaarder (Wissema c.s., 1987)

Vak III heeft betrekking op bedrijfssectoren die qua ICT-toepassingen achterlopen bij de rest, terwijl bovendien de ontwikkelingen op het gebied van ICT achterblijven bij het gemiddelde ontwikkelingstempo. Dit is van toepassing op de sectoren kwarkire diensten en transport en communicatie. Overigens mag worden alangenomen dat van de laatste bedriffsector met name de transport bedrijven verantwoordelijk zijn voor het achterblijven van de ontwikkelingen op ICT gebied. Het risico van kwalificatleverotidering als gevolg van snelle ontwikkelingen op het gebied van informatie- en communicatietechnologie is voor werkenden in deze bedrijfssectoren relatief gering.

In vak IV ten slotte bevinden zich de bedrijfssectoren waarin de ICT toepassingen weliswaar op een vrij hoog niveau liggen, maar war de ontwikkeling achterblift bij het gemiddelde. Deze bedrijfssectoren verliezen weliswaar wat van hun voorsprong maar zij blijven vooralsnog aansluiting houden bij de voorhoede. Het gat hier om de sectoren bank en verzekeringswezen, overbeid en onderwijs, energie, boreca en zakelijke dienstverlening en overige industrie. 
Figuur 3.7

Karakterisering van de stand van zaken in 1997 en de ontwikkelingen op ICT gebied, naar bedrijfssector, 1997-1999

\section{Verwachte ontwikheling tot 1999 (gemiddelde $=100$ )}

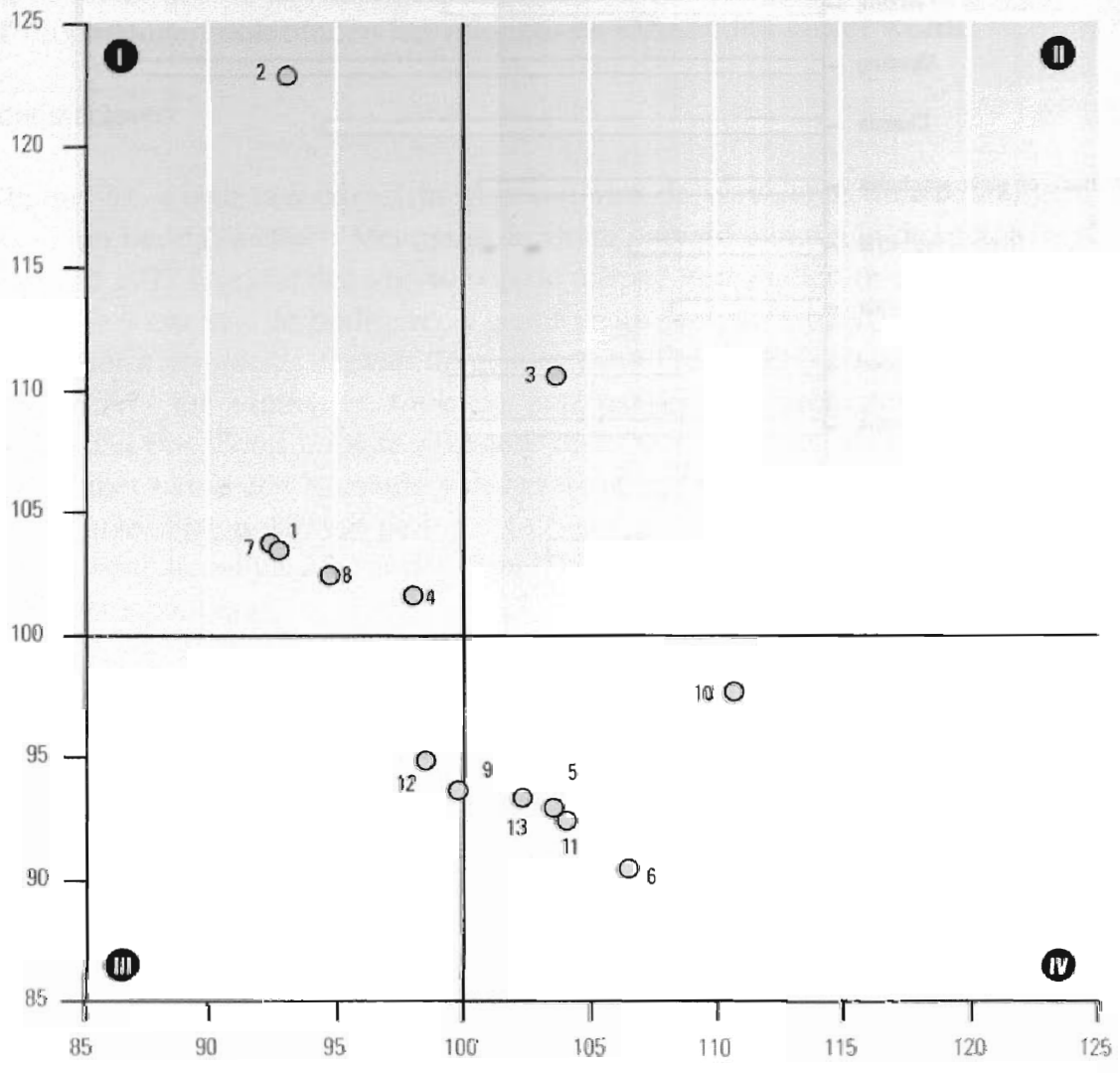

ICT in 1997 (gemiddelde = 100)

1 Landbouw en visserij

2 Voeding

3 Chemie

4 Metaal- en elektrotechniek

5 Dverige industrie

6 Energie

7 Bouw en onroerend goed
8 Handel en reparatie

9 Transport en communicatie

10 Bank-en verzekeringswezen

11 Horeca en zakelijke dienstverlening

12 Kwartaire diensten

13 Overheid en onderwijs

Bron: GBS/ROA

Tevens speet mee dat werkenden in het verleden al het nodige aan ontwikkelingen voor de kiezen hebben gekregen, waardoor zij met nieuwe ICT toepassingen niet zulke grote moeite zullen hebben als werkenden die voor het eerst met dergelijke toepassingen te maken kriigen. 


\subsection{Organisatorische ontwikkelingen}

Niet alleen snelle technologische ontwikkelingen verhogen de kans op kwalificatieveroudering, ook veranderingen op organisatorisch vlak kunnen ertoe bijdragen dat bepaalde kennis en vaardigheden obsoleet worden. In deze paragraaf wordt een overzicht gegeven van die bedrijfssectoren die veel met organisatorische veranderingen te maken hebben. Eerst wordt echter gekeken of de grootte van bedrijven een factor is die een rol speelt als het gaat om organisatorische ontwikkelingen.

\section{Bedrijfsgrootte}

In figuur 3.8 is duidelijk te zien dat het met name de grotere bedrijven zijn die organisatorische veranderingen doorvoeren ${ }^{17}$. Vooral waar het gaat om interne reorganisaties staat het grootbedrijf duidelijk ver voor op het midden- en kleinbedrijf. In $39 \%$ van de bedrijven met 100 tot en met 499 werknemers is in de periode 1994-1996 sprake geweest van een interne reorganisatie. In de bedrijven met 5 tot en met 99 werknemers is dat nog geen 20\%. Grotere bedrijven durven het blijkbaar eerder aan om veranderingen van deze omvang door te voeren. Ook als het gaat om kleine vernieuwingen, ingrijpende vernieuwingen en veranderingen van positie blijkt eenduidig dat in het midden- en kleinbedrijf minder sprake is van organisatorische ontwikkelingen dan in het grootbedrijf.

Overigens blijkt uit verdere analyse ${ }^{18}$ dat de vele reorganisaties binnen de grotere bedrijven over het algemeen niet gepaard gaan met ontslagen. Soms kan het zelfs zo zijn dat een organisatiewijziging ertoe leidt dat meer personeel wordt aangetrokken. Voor de grotere bedrijven leiden organisatiewijzigingen met name tot herplaatsing van personeel en tot scholing. Voor ruim een kwart van de bedrijven in de categorie 100 tot en met 499 werknemers gaan organisatiewijzigingen samen met herplaatsing en scholing. Voor het middenbedriff geldt dat voor ongeveer $10 \%$ van de bedrijven, voor het kleinbedrijf voor nog geen 5\%. Dat veel personeel wordt herplaatst en/of geschoold duidt er op dat sprake is van veranderingen in de vereiste kwalificaties.

Inkrimping met gedwongen ontslag komt niet veel voor, noch in het groothedriff, noch in het midden- en kleinbedrijf. In de bedrijven met 100 tot en met 499 werknemers gaan organisatiewijzigingen in $9 \%$ van de gevallen gepaard met inkrimping en gedwongen ontslag. In de kleinere bedrijven is dat percentage iets lager, ongeveer $4 \%$.

17 Zie ook tabellen 3.7 en 3.8 in de Statistische Bijlage.

18 Zie tabel 3.9 van de Statistische Bijlage. 


\section{Organisatorische ontwikkelingen in de Energiesector}

Binnen de energiesector doet zich een tweetal veranderingen voor, die met name op organisatorisch vlak de komende jaren ingrijpend zullen zijn. Het gaat hierbij om de invoering van de nieuwe Electriciteitswet, die zal leiden tot grotere concurrentie op de (Europese) elektriciteitsmarkt en de ontwikkeling van nieuwe producten en diensten, waarmee energiebedrijven zich steeds meer zullen gaan begeven op andere dan de traditionele markten Daarbij kan met name worden gedacht aan datacommunicatie en afvalverwerking.

Het invoeren van de Electriciteitswet zal er toe leiden dat in 2002 de energiemarkt wordt vrijgegeven en dat de productie en distributie van energie aan internationale concurrentie bloot zal staan. Nu al leidt deze aanstaande vrijgave tot een grote clustering van distributiebedrijven. Bovendien komen veel van de productiebedrijven in buitenlandse handen. Voor de toekomst zijn nog verdere saneringen aangekondigd. De aanstaande fusies van de vier Nederlandse productiebedrijven met binnen- en buitenlandse bedrijven en die van distributiebedrijven onderling zullen gepaard gaan met een verwacht verlies van 1.500 tot 1.750 arbeidsplaatsen. Hierbij gaat het vooral om ondersteunende functies. Binnen de distributiesector zullen als gevolg van de ontwikkelingen nog eens 8.000 arbeidsplaatsen vervallen. Hierbij gaat het vooral om administratief personeel, personeel in middenkaderfuncties en technisch uitvoerend personeel.

De ontwikkelingen op organisatorisch vlak zullen voor een viertal groepen werkenden belangrijke consequenties hebben. Deze groepen zijn:

- Medewerkers van ondersteunende (staf) diensten;

- Jongere technici;

- Oudere technici, die nog niet voor natuurlijke afvloeing in aanmerking komen;

- Oudere technici, die wel in aanmerking komen voor natuurlijke afvloeiing.

Voor de arbeidsmarktpositie van de tweede groep hoeft niet écht te worden gevreesd, omdat de roep om technici in de industrie nog steeds aanhoudt. Met name voor hoger opgeleide jonge technici zijn de arbeidsmarktperspectieven goed te noemen. Voor de eerste groep zal gezocht worden naar mogelijkheden om hen in te zetten op nieuw te creëren afdelingen, zoals PR, marketing en acquisitie. Voor de derde groep is vooralsnog geen duidelijke strategie uitgestippeld. Wel zal in eerste instantie intern naar een oplossing worden gezocht.

Behalve veranderingen in de omvang van de werkgelegenheid zal er vooral sprake zijn van veranderingen in de inhoud van de werkzaamheden en de rol van de medewerkers. De overgang naar een vrije markt maakt het voor werkenden in de energiesector noodzakelijk commercieel en marktconform te leren werken en denken. Hierbij staan klantgerichtheid, communicatieve vaardigheden en service en advies centraal.

De omslag naar een vrije markt kan door middel van opleiding en scholing worden vergemakkelijkt, waarbij een belangrijke rol voor de stichting OEO-fonds Energie en Nutsbedrijuen is weggelegd. De rol die tot aan de omslag was weggelegd voor het 
O\&O-fonds was minimaal, aldus Dhr. S. Wols van de stichting. Nu echter is met een budget van $f 2,5$ miljoen een belangrijke stap gezet om een essentiële rol te gaan vervullen bij het verzorgen van sectorbrede opleiding en ontwikkelingsprogramma's.

Tot voor kort kwamen veel van de door het O\&O-fonds op te starten scholingsprojecten voor kleinere energiebedrijven in aanmerking voor ESF-4 subsidie. Door de grootschalige clustering behoren de meeste energiebedrijven echter niet langer tot het midden- en kleinbedrijf (minder dan 250 fte's). Zij behoorden hierdoor niet langer tot de doelgroepen van het ESF-4 programma, zodat deze subsidiemogelijkheid vervalt. Op jaarbasis scheelt dit zo'n $f 20$ miljoen*.

De enige manier die rest om aan middelen te komen is door internationale samenwerking en via het fiscale loonfonds van de energiebedrijven, waarin door energiebedrijven $0,1 \%$ van het fiscale loon wordt gestort. Met dit loonfonds wordt echter vooralsnog alleen de kwaliteit van de instroom van technici bewaakt en het bijstellen en ontwikkelen van relevante opleidingsprogramma's verzorgd.

* Met het vervallen van het MKB-criterium per 2000 staat voor het O\&O fonds ESF-4 subsidie weer open.

\section{Bronnen:}

Interview met Dhr. S. Wols, Stichting Opleidings- en Ontwikkelingsfonds Energie- en Nutsbedrijven.

P.A. van der Hauw \& Koch, C.L.Y. (1998), Werkgelegenheid en scboling in de energiesector: De kwaliteit van arbeid en toekomstige scbolingsbeboeften. Stichting Industrieel Vakmanschap: Zoetermeer.

\section{Bedrijfssectoren}

Figuur 3.9 geeft een beeld van de organisatorische ontwikkelingen verbijzonderd natar bedriffsector ${ }^{19}$. Met name in de sectoren kwartaire diensten en overbeid en onderwijs is sprake van sterke organisatorische ontwikkelingen. Iets minder snel gaat het in de sector energie. Met name kleinere vernieuwingen aan produkten en diensten worden in de sector kwartaire diensien veel doorgevoerd. In de sector overbeid en onderwijs is meer sprake van ingrijpende vernieuwingen. Een van de redenen hiervoor kan zijn dat curricula, het product van onderwijsinstellingen, jaarlijks forse wijzigingen ondergaan. Ook wat betreft interne reorganisaties en veranderingen van de positie van bedrijven scoren overbeid en onderwijs en kwartaire diensten relatief hoog. In 32\% van de bedrijven in de kwartaire diensten sector was in de periode 1994-1996 sprake van interne reorganisaties. Alleen in de sectoren bank-en verzekeringswezen en energie is dat percentage hoger, respectievelijk 33 en $60 \% 20$. De sector overbeid en onderwijs scoort hier wat lager. $21 \%$.

19 Zie ook de tabellen 3.16 en 3.17 in de Slavistische Rijlage.

20 Vanwege het geringe a antal energiebedrijven in de steekproef dienen de cijfers voor deze sector met enige voorzichtigheid te worden behandeld 
Wanneer wordt gekeken naar de gevolgen van organisatiewijzigingen per sector ${ }^{21}$ dan blijkt dat gedwongen ontslagen het meest voorkomen in de sectoren voeding, kwartaire diensten en handel en reparatie. In ongeveer $8 \%$ van de gevallen waarin sprake is van organisatiewijzigingen volgde in deze sectoren een inkrimping met gedwongen ontslag. In de sector kwartaire diensten volgt op organisatiewijziging wel in veel gevallen herplaatsing en scholing, respectievelijk $20 \%$ en $14 \%$. Hierdoor wordt getracht het aanwezige personeel te behouden. Dat is in de sector bandel en reparatie heel wat minder het geval, daar volgt op organisatiewijzigingen slechts in 9\% van de gevallen herplaatsing en in $6 \%$ van de gevallen scholing.

\section{Figur 3.8}

\section{Organisatorische ontwikkelingen naar bedrijfsgrootte, 1994-1996}

\section{Indices (gemiddelde $=100$ )}

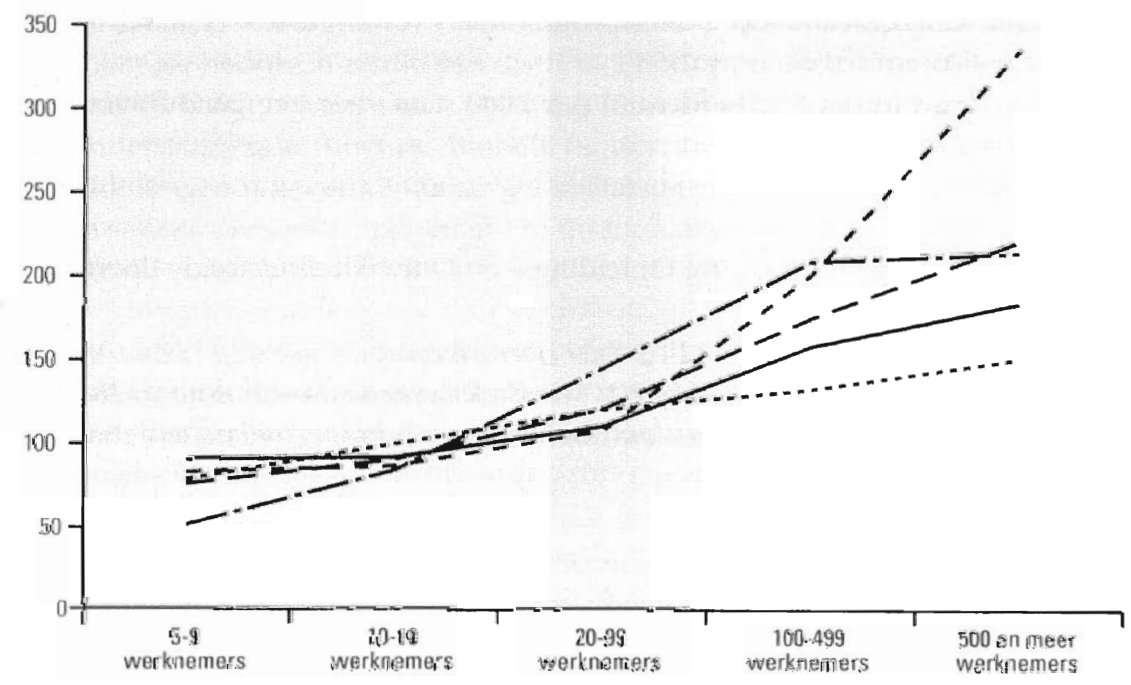

Bedriffsgrootte

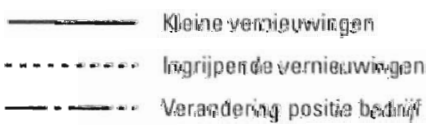

- $\ldots$ - - Interne reorganisaties

- - Organisatorische ontwikkelingen

Bron: OSNROA

Opvallend is overigens ook dat in de sectoren chemie, energie en bank-en verzekeringswezen in de periode 1994-1996 nagenoeg geen sprake was van inkrimping met gedwongen ontslag. De reorganisaties in de sector bank-en verzekeringswezen gaan

21 Zie tabel 3.18 in de Sartisfische Bijlage. 
veel meer gepaard met herplaatsingen en bijvoorbeeld scholing. Zo zijn bij banken de kassiers die door automatisering overtollig zijn geworden veelal herplaatst naar meer commerciële functies. In de meeste gevallen vereiste deze herplaatsing overigens ook een zekere mate van omscholing. Ook blijken de organisatiewijzigingen binnen de sector bank-en verzekeringswezen in bijna één op de vijf gevallen tot een uitbreiding van het personeelsbestand te leiden. Organisatorische ontwikkelingen zorgen in deze sector dus meestal niet voor problemen wat betreft de werkgelegenheid, wel voor een behoefte aan upgrading van kwalificaties. 28 Procent van de organisatiewijzigingen gaat immers gepaard met scholing, waarmee het bank-en verzekeringswezen alle andere sectoren ruimschoots achter zich laat.

\section{Enkele ontwikkelingen gecombineerd}

De figuren 3.10 en 3.11 laten tot slot van deze paragraaf zien in hoeverre de verschillende bedrijfssectoren organisatorische ontwikkelingen combineren met het gebruik van ICT toepassingen (figuur 3.10) en met een hoge R\&D intensiteit (figuur 3.11). In beide figuren is net als in figuur 3.7 een viertal vakken te onderscheiden.

\section{Indices (gemiddelde $=100$ )}

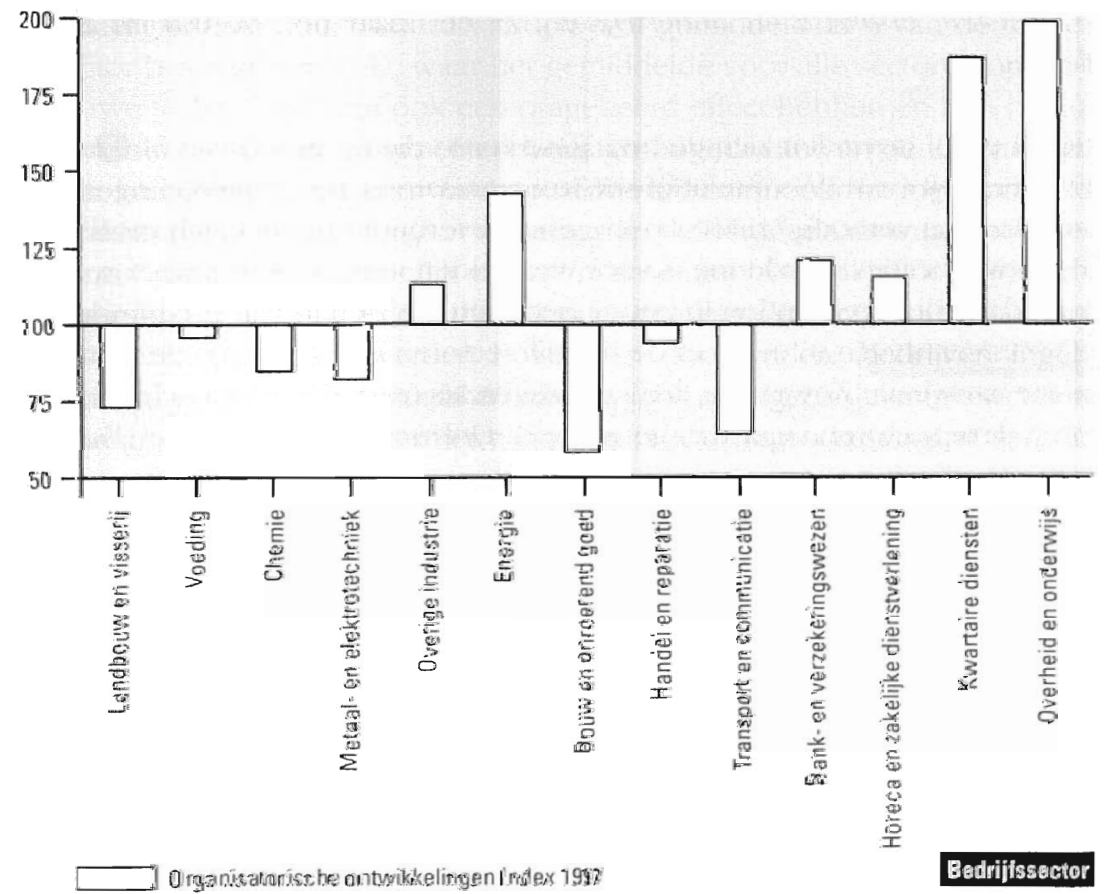


In figuur 3.10 is te zien dat zowel voor wat betreft het gebruik van ICT-toepassingen als voor wat betreft de ontwikkelingen op organisatorisch vlak de sectoren in vak II voorop lopen. Dit zijn de sectoren energie, overbeid en onderwijs, bank-en verzekeringswezen en, zij het in iets mindere mate, boreca en zakelijke dienstverlening. Deze vier sectoren behoren tot de bedrijfssectoren waar het risico van verlies van werk als gevolg van kwalificatieveroudering door relatief snelle technologische en organisatorische ontwikkelingen het grootst is. In de vakken I en IV bevinden zich die sectoren die óf qua organisatorische ontwikkelingen (vak I), óf qua gebruik van ICT toepassingen (vak IV) relatief hoog scoren, maar niet voor beiden. Werkenden in deze sectoren hebben weliswaar nog steeds te maken met een verhoogd risico op kwalificatieveroudering, maar dit risico is wat minder groot dan wanneer beide risicofactoren worden gecombineerd. Voor welke bedrijfssectoren dit speelt is reeds eerder in dit hoofdstuk aan de orde geweest. Vak III ten slotte herbergt die sectoren die zowel qua ICT toepassing als qua organisatorische ontwikkeling onder het gemiddelde scoren. Het risico dat kwalificaties verouderen als gevolg van technologische en/of organisatorische ontwikkelingen is voor deze sectoren het geringst. Werkenden in de sectoren voeding, bandel en reparatie, metaalen elektrotechniek, landbouw en visserij, bouw en onroerend goed en transport en communicatie behoeven zich dus de minste zorgen te maken.

In figuur 3.11 zijn die bedrijfssectoren te onderscheiden die een relatief hoge R\&D intensiteit combineren met snelle organisatorische ontwikkelingen. Ook in deze figuur zijn het de bedrijfssectoren die zich in vak II bevinden, waarvan de werkenden dienen te waken voor een veroudering van kwalificaties als gevolg van snelle ontwikkelingen op technologisch en organisatorisch gebied. De sectoren die zich in dit vak bevinden zijn; kwartaire diensten, overheid en onderwijs en, zij het maar net, boreca en zakelijke dienstverlening.

In de vakken I en IV bevinden zich de bedrifssectoren die op grond van of een relatief hoge R\&D intensiteit (vak IV) óf relatief snelle organisatorische ontwikkelingen (vak I) voor werkenden een verhoogd risico op kwalificatieveroudering met zich meebrengen. Het risico op kwalificatieveroudering is voor werkenden in deze bedriffssectoren echter minder groot dan voor werkenden in bedrijfssectoren die zich in vak II bevinden. Voor mensen die werkzaam zijn in een van de bedrijfssectoren in vak III zijn de risico-factoren het minste aanwezig. Zowel qua R\&D intensiteit als qua organisatorische ontwikkelingen scoren deze sectoren lager dan gemiddeld. Overbeid en onderwijs en boreca en zakelijke dienstwerlening zijn de enige bedrijfssectoren waarbinnen zowel een relatief hoge R\&D intensiteit als een bovengemiddeld gebruik van ICT toepassingen samenvalt met verhoudingsgewijs snelle organisatorische ontwikkelingen.

Het zijn dus met name de werkenden in deze sectoren die het risico lopen te worden geconfronteed met vormen van kwalificatieveroudering, waardoor voor hen de kans op verlies van werk relatief groot is

De bedrijfssectoren war de risico's zowet voor wat betreft een hoge R\&D intensiteit als voor snelle organisatorische ontwikkelingen als voor veel ICT-toepassingen het geringst zijn, zijn de bedrijfssectoren die zowel in figuur 3.10 als in figuur 3.11 in vak III staan. Boum en onroerend goed, bandel en reparatie, landbout en visserif en transport en communicatie zijn de bedriffsectoren warbinnen technologische en organisatorische ontwikkelingen het minst sterk spelen. 
Figuur 3.10

De stand van zaken op het gebied van ICT in 1997 en de organisatorische ontwikkelingen van 1996-1998 gecombineerd

\section{Organisatorische ontwikkelingen (gemiddelde $=100$ )}

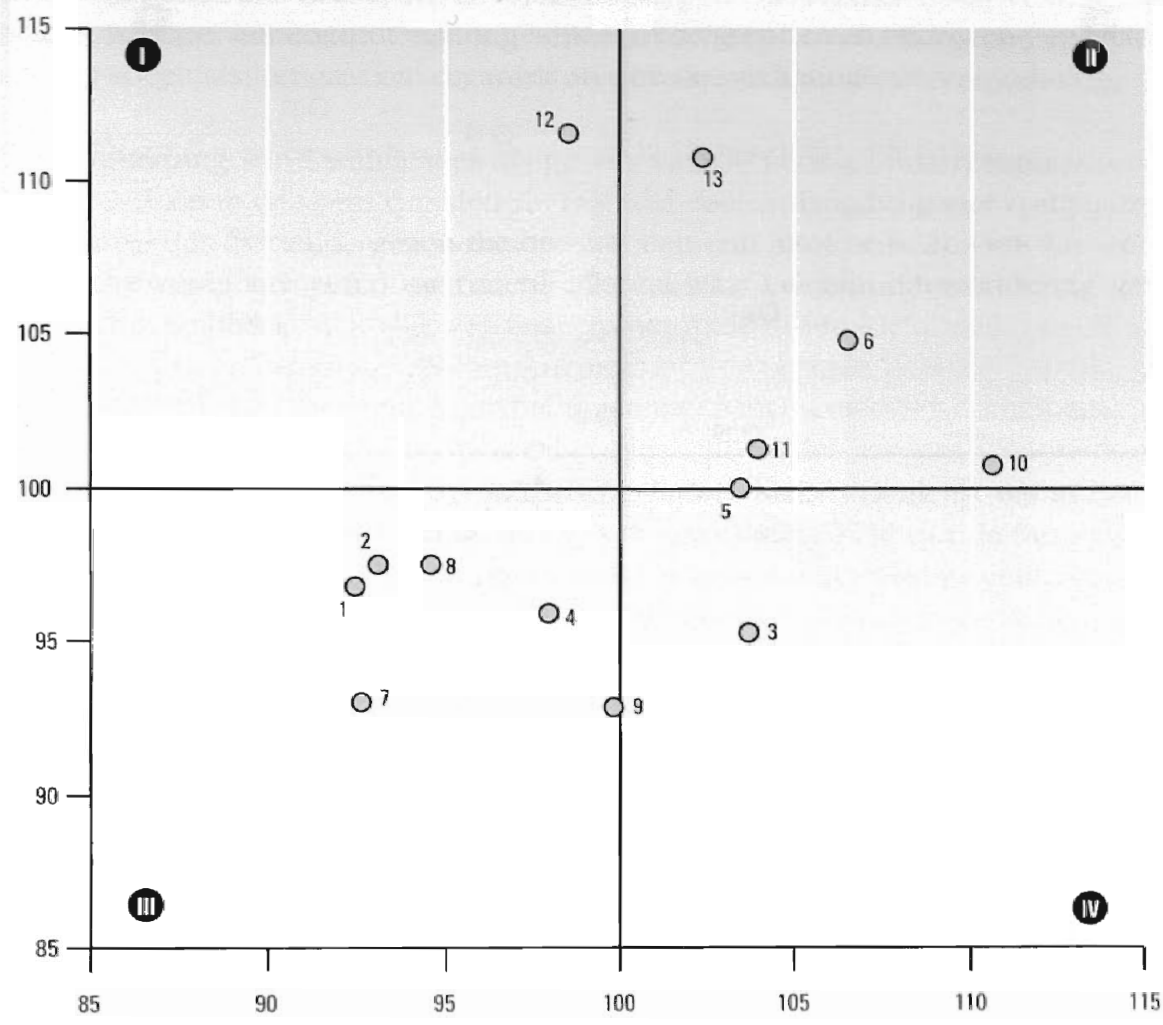

ICT (gemiddelde $=100$ )

1 Landbouw en visserij

2 Voeding

3 Chemie

4 Metaal- en elektratechniek

5 Overige industrie

6 Energie

7 Bouw en anroerend goed
8 Handel en reparatie

9 Transport en communicatie

10 Bank-en verzekeringswezen

11 Horeca en zakelijke dienstverlening

12 Kwartaire diensten

13 Overheid en onderwijs 


\section{Organisatorische ontwikkelingen (gemiddelde $=100$ )}

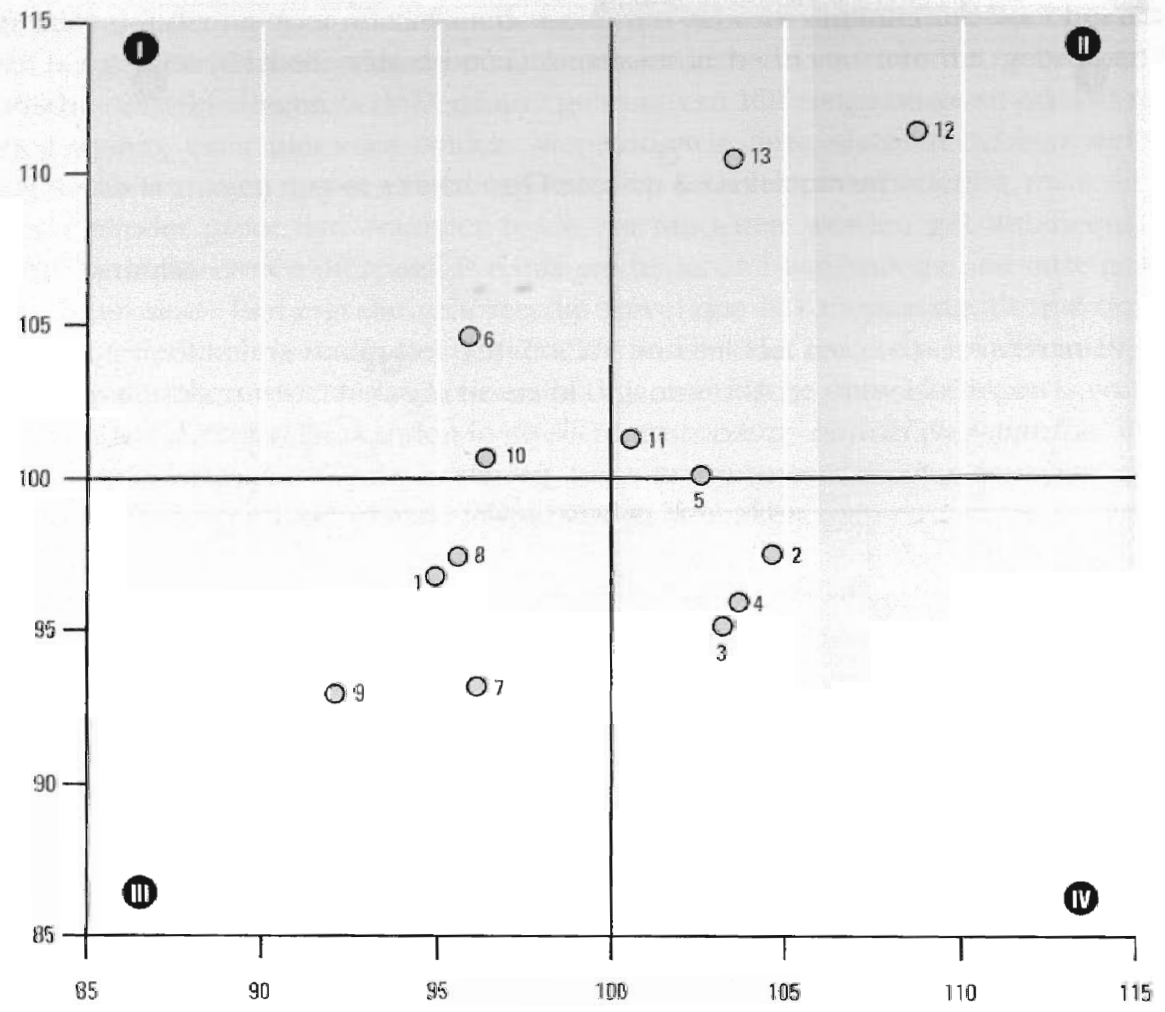

F \& D intensiteit (gemiddeld $=100$ )

1 Landbouw en visserii

2 Voeding

3 Chemie

4 Metaal-en elektrotechniek

5 Overige industrie

6 Energie

7 Bouw en onroerend goed
8 Handel en reparatie

9 Transport en communicatie

10 Bank-en verzekeringswezen

11 Horeca en zakelijke dienstverlening

12 Kwartaire diensten

13 Overheid en onderwijs

Bron: OSNROA 


\subsection{Computergebruik naar opleiding en beroep}

In deze paragraaf wordt een overzicht gegeven van die beroepen en opleidingstypen die worden gekenmerkt door een hoge mate van computergebruik. De analyse richt zich op die beroepen en opleidingstypen waarin gewoonlijk of soms met computers wordt gewerkt. De beroepen en opleidingstypen die relatief hoog scoren voor wat betreft de mate van computerisering behoren tot de risicovolle beroepen en opleidingstypen als het gaat om verlies van werk als gevolg van kwalificatieveroudering.

De veroudering van kwalificaties als gevolg van de voortgaande computerisering kan zich voordoen in de vorm van slijtage. Doordat veel en langdurig met computers wordt gewerkt treden bepaalde gezondheidsrisico's op (zie hoofdstuk 2). Ook kan een snelle computerisering het risico op functie-inhoudelijke kwalificatieveroudering vergroten (De Grip c.s., 1999).

\section{Beroepen}

De tabellen 3.20 en 3.21 van de Statistische Bijlage maken duidelijk dat in het merendeel van de beroepen met computers wordt gewerkt. In $77 \%$ van de beroepsgroepen gebruikt ten minste de helft van de werkenden gewoonlijk of soms een computer. Bij steeds meer beroepsgroepen blijkt vrijwel iedereen wel eens met een computer te werken. Bij de beroepsgroepen informaticien systeemanalisten is het niet vreemd dat $100 \%$ met computers werkt, computers zijn immers hun vak. Deze beide beroepsgroepen behoorden ook twee jaar geleden al tot de tien beroepsgroepen waarin het meeste met computers wordt gewerkt. Naast informatici en systeemanalisten staan nu ook grafisch ontwerpers, taalkundigen, organisatiedeskundigen en politie-inspecteurs en officieren met een computergebruik van $100 \%$ bovenaan in tabel 3.1. Bij de taalkundigen is er bovendien sprake van een aanzienlijke stijging van het percentage computergebruikers met $8 \%$-punt. De grootste toename in het computergebruik wordt echter gevonden bij de bedriffshoofden boreca, watr het percentage computergebruikers met 16\%-punt is toegenomen, van $42 \%$ in 1996 tot $58 \%$ in 1998 .

Tabel 3.1

Beroepsgroepen met de hoogste mate van informatisering, 1998/1996

Beroepsgroep
Grafisch ontwerpers
Taalkundigen
Organisatiedeskundigen
Systeemanalisten
Informatici
Politie-inspecteurs en officieren
Technisch analisten
Assistent accountants
Programmeurs
Technisch systeemanalisten

Bron: CBS/ROA

$\begin{array}{rrr}1998 & \text { typering } & 1996 \\ \% & & \\ 100 & \text { erg hoog } & 95 \\ 100 & \text { erg hoog } & 92 \\ 100 & \text { erg hoog } & 95 \\ 100 & \text { erg hoog } & 99 \\ 100 & \text { erg hoog } & 100 \\ 100 & \text { erg hoog } & \\ 99 & \text { erg hoog } & 93 \\ 99 & \text { erg hoog } & 98 \\ 99 & \text { erg hoog } & 100 \\ 99 & \text { erg hoog } & 99\end{array}$




\section{Opleiding}

Tabel 3.22 van de Statistische Bijlage geeft een overzicht van de mate van informatisering naar opleidingstype. Allereerst wordt duidelijk dat het computergebruik over de gehele linie is toegenomen. De meest in het oog springende uitzonderingen hierop zijn HBO openbare orde en veiligheid en MBO milieu en groene ruimte, waar het percentage werkenden dat een computer gebruikt tussen 1996 en 1998 met 5\%-punt is gedaald. De toename van het computergebruik is het grootst onder werkenden met de opleiding $H B O$ lerarenopleiding economie en maatschappij, MBO beweging en therapie, MBO motorvoertuigentechniek en HBO toerisme en recreatie. De stijging bedraagt ongeveer $12 \%$-punt.

Ook blijkt dat het met name de werkenden zijn met een hogere opleidingsachtergrond die relatief veel met computers werken. Uitzondering hierop is de opleiding $M B O$ geld, bank en belastingen. 98 Procent van de werkenden met deze opleidingsachtergrond makt gebruik van een computer.

In tabel 3.2 staan de tien opleidingstypen vermeld waarvoor geldt dat relatief veel werkenden gewoonlijk of soms met een computer werken. Bovenaan staan de opleidingen WO informatica en bestuurlijke informatiekunde en $H B O$ informatica, met respectievelijk 100 en 99\% computergebruik. Werkenden met een opleiding HBO Informatica hebben in de afgelopen twee jaar iets meer met computers te maken gekregen. Dat geldt overigens ook voor de werkenden met een opleiding WO elektrotechniek, van wie in $199694 \%$ gewoonlijk of soms met een computer werkte en in $199899 \%$.

Tabel 3.2

Opleidingstypen met de hoogste mate van informatisering, 1998/1996

Opleidingstype

Wo informatica en besturielije informatiekunde

HBO informatica

Wo elektrotechniek

MBO geld, bank en belastingen

Wo werktuighouwkunde

wo bouwkunde

Wo farmacie

WO bedriffstiunde

Wo accountancy en belastingen

Wo wiskinde en matururetenschappen
1998

$\%$

100

99

99

98

98

97

97

96

96

95 typering

1996

$\%$

erg hoog $\quad 100$

erg hoog 97

erg hoog 94

erg hoog 97

erg hoog $\quad 90$

erg hoog $\quad 89$

erg hoog

erg hoog $\quad 94$

erg hoog $\quad 98$

erg hoog $\quad 92$

Bron: CBS/ROA

Nieuw in de lijst met tien opleidingstypen met de hoogste mate van informatisering zijn de louter academische opleidingstypen WO werkmigbonaknude. WO bouthunde. WO farmacie en WO wiskunde en natururetenschappen. Verdwenen zijn de opleidingstypen HBO bibliotheek en documentatie. HBO secretariaat. HBO accountancy en bedrifseconomie en HBO dektrotechniek. 


\subsection{Conclusies}

Tabel 3.3 geeft een integraal overzicht van die segmenten op de arbeidsmarkt waar de risico's op verlies van werk als gevolg van kwalificatieveroudering door snelle technologische en organisatorische ontwikkelingen het grootst zijn.

Uit tabel 3.3 komt allereerst naar voren dat vooral de werkenden in grote bedrijven te maken hebben met veel automatisering, een hoge R\&D intensiteit en een groot aantal organisatorische veranderingen, waarbij vooral veranderingen die tot herplaatsingen en/of scholing van werkenden aanleiding geven van belang zijn. Hoewel het voornamelijk de grotere bedrijven zijn waar technologische en organisatorische ontwikkelingen sterk spelen, zijn het in sommige opzichten ook de werkenden in het midden- en kleinbedrijf die moeten waken voor snelle veroudering van hun kwalificaties. Uit figuur 3.5 bleek al dat het juist die bedrijven zijn waar men bezig is met een inhaalslag op het gebied van de ICT-toepassingen. De ontwikkelingen op ICT gebied gaan dus voor het midden- en kleinbedrijf iets sneller dan voor de grotere bedrijven. Dit brengt met zich mee dat kwalificaties in potentie sneller verouderen. Wanneer wordt verbijzonderd naar bedrijfssector valt op dat er binnen veel bedrijfssectoren één of meer risicofactoren een rol spelen.

Binnen de sectoren overbeid en onderwijs, chemie en bank-en verzekeringswezen speelt met name automatisering een grote rol. In de sector overheid en onderwijs spelen daarnaast ook organisatorische veranderingen en R\&D een belangrijke rol.

In de sector chemie is veel minder sprake van organisatorische veranderingen. Wel is er sprake van een hoge R\&D intensiteit. Voor de sector kwartaire diensten wordt een hoge R\&D intensiteit gevonden in combinatie met veel organisatorische ontwikkelingen, terwijl de sectoren energie en voeding op hun beurt gekenmerkt worden door respectievelijk veel organisatorische ontwikkelingen en een hoge R\&D intensiteit. Bijna elke bedrijfssector heeft dus zo haar eigen risico's.

Een vergelijking mer de risicogroepen die in de vorige rapportage werden onderscheiden maakt duidelijk dat de werkenden in de sectoren bank-en verzekeringswezen en voeding niet langer de belangrijkste risicogroepen zijn, hoewel zij overigens wel nog steeds tot de risicogroepen behoren. In de banksector lijkt het erop dat een belangrijke golf van organisatorische veranderingen inmiddels achter de rug is.

In de sector voeding stabiliseert zich het niveau van de R\&D intensiteit. De sectoren overheid en onderwijs en kwartaire diensten komen daarentegen sterker naar voren waar het de risico's op kwalificatieveroudering betreft. Met name de werkenden in de sector kwartaire diensten, waar relatief veel reorganisaties plaatsvinden en gedwongen onislagen vallen, lopen het risico hun werk te verliezen als gevolg van de veroudering van kwalificaties

Het computergebruik is behalve in typische computerberoepen, zoals systeemanalisten en informatici ook zeer hoog onder grafisch ontwerpers, taalkundigen en organisaticdeskundigen. Werkenden die deze beroepen uitoefenen lopen de meesle kans dat door snelle ontwikkelingen op het gebied van de informatie- en communicatietechnologic 
(voortdurend nieuwe hardware en software) hun kwalificaties verouderen. Omdat bovendien computers steeds sneller en zelfstandiger werken doen zich ook nog andere risico's voor. Zo kan een steeds groter deel van het werk door computers zelf worden uitgevoerd, zonder dat menselijk ingrijpen noodzakelijk is. Dat maakt werkenden in sommige gevallen nu al overbodig.

\section{Tabel 3.3}

Belangrijkste segmenten die worden geconfronteerd met snelle technologische en/of organisatorische ontwikkelingen

\section{Risicodimensie}

Technologische en organisatorische ontwikkelingen

Bedriffsgrootle

Bedrijfssectoren

Opleidingen

Computergebruik

Beroepen

Bron: CBS/OSAROA

\section{Risicogroep}

Grote bedrijven

Overheid en onderwijs

Kwartaire diensten

Chemie

Bank- en verzekeringswezen

Energie

Voeding

Grafische ontwerpers

Taalkundigen

Organisatiedeskundigen

Systeemanalisten

Informatici

WO informatica en bestuurlijke informatiekunde

HBO informatica

Wo elektrotechniek

MBO geld, bank en belastingen

Wo werkituigbouwkunde

\section{Aard van de ontwikkeling}

veel automatisering (ICT)

veel R\&D

veel $R \& D$ voor vernieuwing van productieprocessen veel organisatorische veranderingen met personele consequenties (herplaatsing, scholing)

veel automatisering (ICT)

veel organisatorische veranderingen

(veel ingrijpende vernieuwingen)

veel $R \& D$ voor vernieuwing van productieprocessen

veel $R \& D$

veel organisatorische ontwikkelingen (ingrijpende vernieuwingen, reorganisaties, gedwongen ontslagen, herplaatsing)

veel antomatisering (ICT)

veel $R \& D$ voor vernieuwing van productieprocessen

veel automatisering (ICT)

veel organisatorische veranderingen

veel $R \& D$ 
De opleidingstypen die gepaard gaan met een hoge mate van computergebruik zijn logischerwijs de hogere informatica opleidingen; WO informatica en bestuurlijke informatiekunde en $\mathrm{HBO}$ informatica. Bovendien wordt door werkenden met een opleiding WO elektrotechniek, MBO geld, bank en belastingen of WO werktuigbouwkunde veel met computers gewerkt. Werkenden met een van deze opleidingsachtergronden lopen relatief veel risico te maken te kriigen met kwalificatieveroudering als gevolg van ontwikkelingen op computertechnologisch gebied.

\section{Oudere werknemers en technologische en organisatorische ontwikkelingen}

Omdat het met name voor oudere werkenden wat lastiger is om zich voortdurend aan te passen aan allerlei nieuwe computerprogramma's, communicatiemiddelen en organisatiestructuren is het zinvol te bezien in hoeverre oudere werkenden vertegenwoordigd zijn in die sectoren, beroepen en opleidingstypen waar technologische en organisatorische vernieuwingen het meest voorkomen.

Een nadere beschouwing van het percentage oudere werknemers (50-64 jaar) maakt duidelijk dat vooral in de sector overbeid en onderwijs het aundeel van de ouderen relatief hoog is. Omdat binnen deze sector bovendien op technologisch en organisatorisch gebied snelle veranderingen plaats hebben, lijkt het noodzakelijk om aan de oudere werkenden in deze sector extra aandacht te schenken.

In de sector energie zijn het niet zozeer technologische veranderingen die het het relatief hoge percentage ouderen mogelijk moeilijk maken, maar veel meer de organisatorische ontwikkelingen. Dit bleek ook al uit het kader dat zich op de organisatorische ontwikkelingen in de energiesector toespitste.

Voor de in dit hoofdstuk onderscheiden risicoberoepen is geen sprake van een relatief groot aandeel van oudere werknemers. De gemiddelde leeftijd van de werknemers in de vijf belangrijkste risicoberoepen wordt gekarakteriseerd als gemiddeld tot hag.

Bij de onderscheiden risicogroepen naar opleidingstype geldt alleen voor de werkenden met een opleiding $M B O$ geld, bank en belastingen dat het percentage oudere werknemers relatief hoog ligt. De gemiddelde leeftijd van werknemers in deze risicogroep is bijna 42 jaar. 


\section{Arbeidsmarktontwikkelingen}

\subsection{Inleiding}

Economische kwalificatieveroudering heeft niet altijd een technologische of organisatorische achtergrond, maar kan ook het gevolg zijn van ontwikkelingen op de arbeidsmarkt. Werknemers die hun baan verliezen en op zoek moeten naar een andere baan zullen een deel van hun kennis en vaardigheden niet meer kunnen benutten en zullen daarnaast vaak nieuwe kennis en vaardigheden moeten verwerven. Dat is niet alleen het geval als iemand van beroep moet veranderen maar ook als iemand wel hetzelfde beroep houdt, maar in een andere bedrijfssector gaat werken. Een deel van de voor een bepaalde baan vereiste kennis en vaardigheden is immers specifiek voor de bedriffsector waarin iemand werkt. In beide gevallen zal er overigens eveneens sprake zijn van bedrijfsspecifieke kwalificatieveroudering, ondat ook bedrijfsspecifieke kennis en vaardigheden niet meer bruikbaar zijn 22 . De grootste kwalificatieveroudering zal zich echter doorgaans voordoen als iemand van beroep moet veranderen. Het is daarom nuttig om een beeld te hebben van de arbeidsmarktontwikkelingen die tot kwalificatieveroudering kunnen leiden. Op grond van de verwachte ontwikkelingen op de arbeidsmarkt kunnen de groepen werknemers worden geïdentificeerd die vanuit deze optiek het grootste risico lopen op kwalificatieveroudering.

In dit hoofdstuk zal worden gekeken naar het risico op verlies van werk als gevolg van arbeidsmarktontwikkelingen. Hierbij zal onderscheid worden gemaakt tussen verschillende vormen van kwalificatieveroudering die een risico op baanverlies met zich mee kunnen brengen. Eerst wordt ingegaan op de kwalificatieveroudering die zich kan voordoen als gevolg van krimpende werkgelegenheid of verschuivingen in de werkgelegenheidsstructuur. Daarna wordt de problematiek van functie-inhoudelijke kwalificatieveroudering in beeld gebracht voor zover deze tot uiting komt in de toename van het vereiste opleidingsniveau voor een beroep (het zogenaamde upgradingsproces) of een verschuiving van de opleidingsrichting die gevraagd wordt voor een bepaald beroep.

De werkgelegenheidsontwikkeling in een beroep kan op verschillende niveaus worden belicht. Ten eerste kan er worden gekeken naar de totale werkgelegenheid in een beroep. Als er sprake is van een toename van de totale werkgelegenheid spreken we van netto baancreatie. Als de totale werkgelegenheid daarentegen afneemt, is er sprake van netto baanvernietiging. In het laatste geval is het echter mogelijk dat de werkgelegenheid voor het betreffende beroep in een bepaalde bedrijfsector toeneemt, terwijl in een andere bedrijfssector de werkgelegenheid voor datzelfde beroep daalt. De netto baanvernietiging of -creatie kan derhalve worden opgesplitst in de bruto baanvernietiging en de bruto baancreatie. Zo neemt bijvoorbeeld de werkgelegenheid voor melaalarbeiders in de sector transportmiddelen toe. In de sector bandel en reparatie neemt de

22 Bedriffsspecifieke kwalificatie-veroudering doet zich overigens niet alleen voor in krimpende arbeidsmarktsegmenten maar ook in groeiende segmenten, ondat er ook daar bij minder gocd florerende bedrijen banen verloren kunnen gaan. 
werkgelegenheid voor diezelfde beroepsgroep daarentegen af. Ook binnen een bedrijfssector kan tegelijkertijd sprake zijn van baanvernietiging en baancreatie doordat er bij sommige bedrijven banen bijkomen en er bij andere bedrijven banen verdwijnen 23

Doordat in de ene bedrijfssector sprake is van netto baancreatie in een bepaald beroep, terwijl in een andere sector sprake is van netto baanvernietiging in datzelfde beroep, zal mogelijk een aantal werkenden van bedrijfstak moeten veranderen. Deze werkgelegenheidsverschuivingen tussen bedrijfssectoren noemen we de reallocatie van de werkgelegenheid. Zoals gezegd leidt reallocatie tussen bedriffssectoren tot economische kwalificatie-veroudering, omdat een deel van de kwalificaties waarover iemand beschikt specifiek is voor de bedrijfssector waarin iemand werkzaam is. Naast reallocatie tussen bedrijfssectoren zal er ook sprake zijn van reallocatie tussen bedrijven binnen één bedriifssector. Als bedrijfsspecifieke kennis en vaardigheden van groot belang zijn, zal ook dit tot bedrijfsspecifieke kwalificatie-veroudering leiden.

In paragraaf 4.2 van dit hoofdstuk zal worden ingegaan op de ontwikkelingen die kunnen bijdragen aan het risico op kwalificatieveroudering door een krimpende werkgelegenheid of een reallocatie van de werkgelegenheid. Hierbij zal worden verbijzonderd naar bedrijfssector, benoepssegment en de opleidingsachtergrond van werkenden.

Uit het themarapport Scholing van Werkenden (De Grip, Van Loo, De Steur, 1999) komt naar voren dat wanneer iemand een flexibel dienstverband heeft, dit een risico-verhogende factor is voor de kans op het verlies van werk als gevolg van kwalificatieveroudering vanwege ontwikkelingen op de arbeidsmarkt. Bij een krimpende werkgelegenheid of wanneer reorganisaties noodzakelijk zijn, kunnen werkgevers hun personeelsbestand immers eenvoudig inkrimpen door het beëindigen van flexibele arbeidscontracten. Daarom zal aan het einde van de paragraaf expliciet worden ingegaan op de mate waarin flexibele arbeidscontracten voorkomen in de bedrijfssectoren, beroepen en opleidingscategoriëen waarvoor een aanzienlijke werkgelegenheidskrimp of -reallocatie wordt verwacht

De werkgelegenheidsontwikkeling per beroep kan het gevolg zijn van verschuivingen in de werkgelegenheid tussen bedrijfssectoren (het bedrifssectoreffect'). Daarnaast kunnen ook binnen bedriffssectoren verschuivingen optreden tussen beroepssegmenten (het 'beroepseffect'). Beide effecten leiden tot kwalificatieveroudering door marktontwikkelingen. Bij de ontwikkeling van de vraag naar mensen met een bepaalde opleidingsachtergrond kan zich bovendien een derde effect voordoen. Indien zich binnen een beroepssegment verschuivingen voordoen in de opleidingsachtergronden van werkenden, spreekt men van een 'opleidingseffect'. De latatstgenoemde verschuivingen kunnen leiden tot functie- inhoudelijke kwalificatieveroudering. De opleidingsachtergrond die iemand heeft voldoet dan niet langer an de veranderde kwalificatie-eisen die aan de werkenden in het desbetreffende beroep worden gesteld. In paragraaf $4.3 \mathrm{zal}$

23 Het atmal nicuwe banen in de bedrijfsector noenen we de bruto baancreatie op bedrijfsectorniveal: het antal banen dat bij bepaalde bedrijven verdwijnt de bruto baanvernietiging op bedrijfssectomivean. 
hierop worden ingegaan. Hierbij zal er een overzicht gegeven worden van de verschuiving van de vereiste kwalificaties binnen beroepssegmenten.

Als er in een beroepssegment sprake is van een voortdurende upgrading van de functie-eisen, zullen het met name de oudere arbeidskrachten zijn bij wie de kwalificaties tekortschieten. Het is immers reeds lang geleden dat zij hun initiële opleiding hebben gevolgd. Wanneer zij naast hun werk weinig hebben geparticipeerd in (bij)scholingsactiviteiten, zullen de kwalificaties waarover zij beschikken achter zijn gebleven bij de vereiste competenties voor de functie die zij uitoefenen. Oudere arbeidskrachten hebben daarom een groter risico om hun baan te verliezen door een tekortschietende opleidingsachtergrond ${ }^{24}$. Om die reden zal in paragraaf 4.3 eveneens worden aangegeven in welke mate het opleidingsniveau van ouderen in verschillende beroepen afwijkt van het opleidingsniveau van de andere werkenden.

Ten slotte wordt in paragraaf 4.4 een samenvattend overzicht gegeven van de bedrijfssectoren, beroepssegmenten en opleidingsachtergronden waarvoor een grote kans op het verlies van werk bestaat als gevolg van de verschillende vormen van kwalificatieveroudering die het gevolg zijn van ontwikkelingen op de arbeidsmarkt.

\subsection{Kwalificatieveroudering als gevolg van een krimpende werkgelegenheid of reallocatieprocessen}

\section{Bedrijfssector}

In het ROA-rapport De arbeidsmarkt naar opleiding en beroep tot 2004 worden prognoses gepresenteerd van de arbeidsmarktontwikkelingen op de diverse segmenten van de arbeidsmarkt. Gezien de voortdurende 'onzekerheden en turbukntie in de wereldeconomie' en de onzekerheid over het voortduren van de hausse op de effectenbeurzen en de woningmarkt ${ }^{25}$, zijn de prognoses van de werkgelegenheidsontwikkeling in deze prognosestudie gebaseerd op het zogenaamde 'behoedzame scenario' van het Centraal Planbureau.

Zoals tabel 4.1 laat zien, betekent dit dat de totale werkgelegenheid de komende jaren minder sterk zal toenemen dan in de afgelopen jaren. Slechts vier sectoren vormen op dit punt een uitzondering. Voor de sector landboum en visserij zal de werkgelegenheidskrimp, ondanks de verwachte sterke toename van de arbeidsproductiviteit, de komende jaren naar verwachting iets minder groot zijn dan in de afgelopen jaren. Voor de sector chemie, ligt de werkgelegenheidsgroei de komende jaren naar verwachting op? een wat hoger niveau dan in de periode 1994-1998. De gematigde werkgelegenheidsgroei in de periode 1994-1998 werd vooral veroorzaakt door de werkgelegenheidskrimp die zich als gevolg van de sterke toename van de arbeidsproductiviteit voordeed in de chemische industrie in de jaren 1994-1996. Voor de sector energie die, eveneens van. wege de sterke toename van de arbeidsproductiviteit, de afgelopen jaren te kampen

24 Dit blijkt ook uit hef eerdere themarapport Scboling ean Werkenden (De Grip, Van Loo, De Steur. 1999)

25 Centraal Planbureau, Centraal Economisch Plan 1999, Den Haag, 1999 
Tabel 4.1

Ontwikkeling van het aantal werkenden per bedrijfssector 1994-1998 en de uitbreidingsvraag 1999-2004 (gemiddelde jaarlijkse percentages)

$\begin{array}{lccc}\text { Bedrijfssector } & \begin{array}{c}\text { aantal werkenden } \\ \text { (gem. 1997-1998) }\end{array} & \begin{array}{c}\text { 1994-1998 } \\ \%\end{array} & \begin{array}{c}\text { 1999-2004 } \\ \%\end{array} \\ \text { Landbouw en visserij } & 224.500 & -1,8 & -1,4 \\ \text { Voeding } & 159.000 & -0,6 & -0,9 \\ \text { Chemie } & 125.000 & 0,4 & 0,8 \\ \text { Metaal en elektrotechniek } & 510.000 & 1,1 & -0,1 \\ \text { Overige industrie } & 217.000 & 0,1 & -0,3 \\ \text { Energie } & 62.500 & -0,8 & -0,1 \\ \text { Bouw en onroerend goed } & 484.000 & 0,7 & -0,6 \\ \text { Handel en reparatie } & 899.000 & 3,1 & 1,9 \\ \text { Transport en communicatie } & 390.500 & 1,7 & 1,2 \\ \text { Bank- en verzekeringswezen } & 242.000 & -0,2 & -0,2 \\ \text { Horeca en zakelijke dienstverlening } & 986.500 & 5,7 & 2,3 \\ \text { Kwartaire diensten } & 1.070 .500 & 2,2 & 1,9 \\ \text { Overheid en onderwiis } & 917.000 & -0,6 & 0,4 \\ \text { Totaal (incl. sector onbekend) } & & & 1,0\end{array}$

Bron: CBS/CPB/ROA

heeft gehad met sterk krimpende werkgelegenheid, wordt voor de komende jaren een veel geringere werkgelegenheidsdaling verwacht. Ten slotte wordt voor de sector overbeid en onderwijs verwacht dat de werkgelegenheidskrimp van de afgelopen jaren zal omslaan in een geringe toename van de werkgelegenheid.

Om de risico's op verlies van werk vanwege de vraagontwikkelingen op de arbeidsmarkt te traceren gaat vanzelfsprekend de aandacht met name uit naar de werkenden in de sectoren met een krimpende werkgelegenheid. Deze risico's zijn derhalve de komende jaren het grootst in de sector landbouw en visserij. Daarnaast zijn er duidelijke risico's op baanverlies vanwege krimpende werkgelegenheid in de conjunctuurgevoelige bouw en industrielle sectoren.

\section{Arbeidsmarktontwikkelingen: de Varkenssector}

Het uitbreken van de varkenspest heeft in de varkenssector een aantal verstrekkende gevolgen gehad. De inkrimping van de varkensstapel heeft ingrijpende gevolgen voor de positie van de varkenshouders. Veel varkenshouders worden geconfronteerd met een dreigend verlies van werk. Om te proberen dit verlies van werk zoveel mogelijk te voorkomen is in september 1998 het Saciaal Economisch Plan (SEP) Varkenshouderij in werking getreden. Dit plan komt voort uit een samenwerkingsverband van LTO-Nederland, het Nederlands Agrarisch Jongeren Kontakt (NAJK) en de Stichting Agrarische Vrouwen en Herstructurering in de Land- en Tuinbouw (SAVH).

Doel van het SEP Varkenshouderij is het geven van advies en begeleiding aan varkenshouders en hun gezinsleden om ervoor te zorgen dat zij weloverwogen tot beslissingen komen over de continuiteit van hun bedrijf. Het advies kan gericht zijn 
op een verdere ontwikkeling en voortzetting van het bedrijf, maar het kan er ook op neerkomen dat varkenshouders moeten gaan uitzien naar ander werk.

SEP Varkenshouderij is opgezet rondom een drietal basisactiviteiten: voorlichting, advisering en begeleiding. In de meeste trajecten die varkenshouders worden aangeboden is echter sprake van een mix van deze drie activiteiten. De uitvoering van het SEP spitst zich toe op een vijftal taken:

1. informeren over ontwikkelingen binnen en buiten de sector;

2. persoonlijke begeleiding en advisering aan varkenshouders om hen in staat te stellen zich beter te oriënteren op de toekomst;

3. varkenshouders zicht bieden op hun kernkwaliteiten;

4. varkenshouders, indien nodig, de omslag laten maken naar opheffing van hun bedrijf en helpen bij het zoeken naar andere arbeidsmogelijkheden;

5. begeleiding bieden bij het ontwikkelen van het bedrijf of begeleiding naar de arbeidsmarkt.

Binnen het SEP-kader zijn er verschillende samenwerkingsverbanden tot stand gebracht die geleid hebben tot een breed aanbod van cursussen en begeleidingstrajecten. In deze trajecten kunnen vier hoofdthema's worden onderscheiden:

- persoonlijke begeleiding, bedoeld voor varkenshouders en hun gezinnen wanneer zij niet weten welke weg ze moeten inslaan.

- hulp bij het verwerkingsproces na eventuele bedrijfsbeëindiging.

- begeleiding naar andere arbeid: in samenwerking met RBA's, particuliere organisaties, adviesorganisaties en regionale LTO organisaties worden per regio trajecten uitgezet voor heroriëntatie op arbeid en herplaatsing. Door middel van zelfonderzoek, persoonlijkheidstesten en individuele gesprekken krijgen zowel de varkenshouders zelf als de adviseurs zicht op de interesses, kwalificaties, vaardigheden en mogelijkheden voor de arbeidsmarkt.

- oriëntatiecursussen bedrijfsontwikkeling en innovatie, bedoeld voor varkenshouders die willen en kunnen doorgaan. Hier worden mogelijkheden voor toekomstgericht ondernemen toegelicht.

De resultaten na één jaar SEP Varkenshouderij kunnen bemoedigend genoemd worden. Een groot aantal varkenshouders is bereikt en een aanzienlijk deel van hen is zich ook bewust geworden van de situatie waarin zij verkeren. Tabel 1 laat de belangrijkste resultaten zien.

Tabel 1

Resultaten 1 jaar SEP Varkenshouderij

Bezoekers voorlichtingsbijeenkomsten $\quad 16.000$

Helpdesk/infolijn $\quad 7.500$

$\begin{array}{ll}\text { Adviesvragen } & 2.400 \\ \text { Pesoat } & \end{array}$

Persoonlijke begeleiding $\quad * \quad 200$

Begeleiding arbeidsmarkt

Cursussen/studiegroepen

Verwerking beëindiging $\quad 100$

Bron: Odyssee Maatschappelijke Ontwikkeling, Sociaal Economisch Plan Varkenshouderij, 1999. 


\section{Beroep}

Zoals eerder al gezegd, kunnen veranderingen van de werkgelegenheid in de beroepen worden veroorzaakt door werkgelegenheidsverschuivingen tussen verschillende bedrijfssectoren en door verschuivingen in de beroepenstructuur van de werkgelegenheid binnen bedrijfssectoren. Dit betekent dat in de praktijk de uitbreidingsvraag voor beroepen nog veel sterker uiteenloopt dan de werkgelegenheidsontwikkeling in de diverse bedrijfssectoren.

Tabel 4.2

Beroepssegmenten met procentueel gezien de grootste netto baanvernietiging in de periode 1999 2004 (totaal aantal en gemiddeld jaarlijks percentage)

\section{Beroepssegment}

Middeibare wiskundige, natuuwetenschappelijke beroepen

Lagere technische beroepen

Middelbare technische beroepen

lagere agrarische beroepen

Wetenschappelijke technische beroepen

Lagere niet-specialistische beroepen

Hogere technische beroepen

Middelbare agrarische beroepen

Lagere (para)medische beroepen

Hogere pedagogische beroepen

lagere verzorgende beroepen

$\begin{array}{rr}\text { aantal } & \% \\ 4.300 & 9,0 \\ 113.300 & 5,5 \\ 3.700 & 3,0 \\ 13.400 & 2,7 \\ 1.900 & 2,0 \\ 200 & 1,0 \\ 1.900 & 1,0 \\ 5.600 & 0,9 \\ 900 & 0,8 \\ 500 & 0,5 \\ 2.600 & 0.3\end{array}$

Bron: ROA

Uit tabel 4.2 komt naar voren dat met name voor de technische en agrarische beroepen op lager en middelbaar niveau de komende jaren naar verwachting sprake zal zijn van een aanzienlijke netto baanvernietiging 26 . Deze beroepssegmenten ondervinden vanzelfsprekend de grootste klappen van de krimpende werkgelegenheid in de agrarische sector en de meeste industriële bedrijfssectoren. Bovendien hebben met name werkenden in de agrarische beroepssegmenten geen grote uitwijkmogelijkheden naar andere bedrijfssectoren, waardoor zij niet of nauwelijks mee kunnen profiteren van de werkgelegenheidstoename in die andere bedriffssectoren.

Voor het beroepssegment middelbare wiskundige, natuurwetenschappelijke beroepen, dat vooral betrekking heeft op laboranten, wordt relatief gezien de grootste netto baanvernietiging verwacht. Het aantal werkenden in dit beroepssegment zal in vijf jaar tijd met maar liefst ruim een derde afnemen. In absolute zin zal het aantal werkenden binnen de lagere technische beroepen het sterkst afnemen. Hier bedraagt de daling in de werkgelegenheid ruim 110.000 en dat is bijna een kwart van de totale werkgelegenheid bimnen dit beroepssegment.

Naast de technische en agrarische beroepssegmenten wordt ook netto baanvernietiging verwacht voor de bogere pedagogische beroepen, de lagere verzorgende beroepen en de

26 Zie tabel 4.2 van de Statistische Bijlage voor een volledig overzicht. 
lagere (para)medische beroepen. Voor deze beroepen is het risico op baanverlies als gevolg van kwalificatieveroudering door marktontwikkelingen derhalve het grootst.

Ook is het mogelijk dat de werkgelegenheid in een bepaald beroep in een bedrijfssector krimpt, terwijl de werkgelegenheid voor datzelfde beroep in een andere bedriffssector groeit. Dat betekent dat degenen die werkzaam zijn in de sector waarin de werkgelegenheid voor een beroep krimpt, bij verlies van hun baan toch werkzaam kunnen blijven in hun beroep, wanneer ze uitwijken naar een groeiende bedrijfssector. Deze sectorale reallocatie van de werkgelegenheid in een beroepsgroep kan leiden tot kwalificatieveroudering, omdat de vereiste vaardigheden en kennis voor een bepaald beroep kunnen verschillen tussen bedrijfssectoren.

In tabel 4.3 wordt een overzicht gegeven van de beroepssegmenten waarvoor in absolute zin de hoogste sectorale reallocatie wordt verwacht ${ }^{27}$. Het betreft voornamelijk lagere en middelbare beroepen, maar ook voor een aantal hogere beroepen wordt een aanzienlijke sectorale reallocatie van de werkgelegenheid verwacht. In de lagere administratieve, commerciële beroepen zouden liefst 16.600 werkenden uit moeten wijken naar een andere bedrijfssector om in hetzelfde beroep werkzaam te kunnen blijven. Tabel 4.3 komt sterk overeen met het overzicht van de beroepssegmenten waarvoor in het vorige overzichtsrapport Werkgelegenbeid en scholing 1997 een aanzienlijke sectorale reallocatie werd verwacht. De omvang van de sectorale reallocatie is ditmaal echter aanzienlijk hoger:

Tabel 4.3

Beroepssegmenten met de grootste sectorale reallacatie in de periode 1999-2004 (totaal en gemiddelde jaarlijkse percentage)

Beroepssegment

Lagere administratieve, commerciële beroepen

Middelbare technische beroepen

Elementaire beroepen

Lagere technische beroepen

Hogere administratieve, commerciële, economische beroepen

Lagere verzorgende beroepen

Hogere technische beroepen

Middelbare agrarische beroepen

Lagere agrarische beroepen

Middelbare transportberoepen

Hogere taalkundige, culturele beroepen aantal $\%$

$16.600 \quad 0,6$

$11.700 \quad 0,3$

$9.900 \quad 0,4$

$8.100 \quad 0,3$

$5.200 \quad 0,2$

$5.100 \quad 0,6$

$2.200 \quad 0,4$

$1.600 \quad 0,2$

$800 \quad 0,1$

$800 \quad 0,3$

$800 \quad 0,3$

Bron: ROA

Voor een aantal beroepssegmenten wordt er zowel een aanzienlijke reallocatic van de werkgelegenheid als een grote netto baanvernietiging verwacht. Dit is het geval bij de lagere verzorgende beroepen, de lagere en middelbare agrarische beroepen en de technische beroepen op lager, middelbaar en hoger niveau. In deze beroepen zullen de werkenden die hun baan verliezen slechts voor een deel uit kunnen wijken naar soort-

27 Zie tabel 4.3 in de Statistische Bijlage voor een volledig overzich van de sectorale reallocatie per beroepssegment 
Tabel 4.4

Verwachte relatieve baanvernietiging per bedrijfssector voor beroepssegmenten waar sprake is van netto baanvernietiging, 1999-2004

Beroepssegment

Lagere niet-specialistische beroepen

Horeca en zakelijke dienstverlening

Lagere agrarische beroepen

Landbouw en visserij

Metaal en elektrotechniek

Handel en reparatie

Overheid en Onderwijs

Lagere technische beroepen

Voeding

Overige Industrie

Metaal en elektrotechniek

Bouw en onroerend goed

Transport en communicatie

Kwartaire diensten

overheid en Onderwijs

Lagere (para)medische beroepen

Kwartaire diensten

Lagere verzorgende beroepen

Kwartaire diensten

Middelbare agrarische beroepen Landbouw en visserij

Overheid en Onderwijs

Middelbare technische beroepen

Landlbouw en visserij

Voeding

Overige Industrie

Energie

Bouw en onroerend goed

Transport en communicatie

Horeca en zakelijke dienstverlening

Kwartaire diensten

Overheid en Onderwijs

Middelbare transportberoepen

Transport en communicatie

Hogere technische beroepen

Voeding

Overige Industrie

Energie

Bouw en onroerend goed

overheid en Ondenviis

Brom: $\mathbb{R O A}$ 
gelijke functies in een andere bedrijfssector. Anderen zullen moeten uitwijken naar een ander beroep.

Uit het feit dat er sprake is van sectorale reallocatie blijkt al dat het risico op baanverlies voor werkenden in een bepaald beroepssegment niet in alle bedrijfssectoren gelijk is. Het is dan ook nuttig een overzicht te hebben van de bedriffssectoren waarin de netto

\section{Tabel 4.5}

Verwachte relatieve baanvernietiging per bedrijfssector voor beroepssegmenten waar sprake is van netto baancreatie, 1999-2004

\section{Beroepssegment}

\section{Elementaire beroepen}

Bouw en onroerend goed

Overheid en Onderwijs

Voeding

Overige industrie

Metaal en elektrotechniek

Lagere administratieve, commerciële beroepen

Voeding

Overige industrie

Metaal en elektrotechniek

Energie

Bouw en onroerend goed

Transport en communicatie

Horeca en zakelijke dienstverlening

Bank-en verzekeringswezen

Kwartaire diensten

Overheid en Onderwijs

Middelbare (para)medische beroepen

Overheid en Onderwijs

Middelbare verzorgende beroepen

overheid en Onderwijs

Hogere administratieve, commerciële, economische beroepen

Voeding

Overige industrie

Metaal en elektrotechniek

Bouw en onroerend goed

Bank- en verzekeringswezen

Hogere juridische, bestuurlijke, beveiligingsberoepen

Overheid en onderwijs

Hogere taalkundige, culturele beroepen

Overige industrie

Overheid en onderwiis

Managers (wetenschappelijk werk- en denkniveau)

Metaal en elektrotechniek

Bouw en onmerend goed 
baanvernietiging het grootst is voor de verschillende beroepssegmenten. Tabel 4.4 geeft dit overzicht voor de beroepssegmenten waarvoor sprake is van een netto baanvernietiging 28 .

Uit tabel 4.4 komt naar voren dat voor veel van de beroepssegmenten de krimpende werkgelegenheid in meerdere bedrijfssectoren optreedt. Opmerkelijk is de relatief sterke werkgelegenheidskrimp die verwacht wordt voor de lagene en middelbare technische beroepen in de sector overbeid en onderwijs.

Uitzonderingen hierop zijn de lagere verzorgende beroepen, de lagere (para)medische beroepen, de lagere niet-specialistische beroepen en de middelbare transportberoepen, waarvoor de krimp met name optreedt in één bepaalde bedrijfssector. Uit tabel 4.5 blijkt dat ook voor beroepssegmenten waarvoor per saldo een groei van de werkgelegenheid wordt verwacht toch in verschillende sectoren de werkgelegenheid kan afnemen. In deze sectoren is daardoor sprake van een duidelijke reallocatie van de werkgelegenheid. Zo blijkt de werkgelegenheid in de lagere administratieve, commerciële beroepen met name in de kwartaire diensten, bouw en onroerend goed en transport en communicatie af te nemen. De krimp in de werkgelegenheid in de bedrijfssector overbeid en onderwijs treft ook een flink aantal beroepssegmenten waarvoor een groeiende werkgelegenheid wordt verwacht. Dit zijn onder meer de elementaire beroepen, de middelbare (para)medische beroepen, de middelbare verzorgende beroepen, de bogere taalkundige, culturele beroepen en de bogere, juridische, bestuurlijke beveiligingsberoepen.

\section{Opleiding}

Verschuivingen in de werkgelegenheid per opleidingstype kunnen, zoals gezegd, zowel het gevolg zijn van (netto) baanvernietiging in beroepssegmenten waar mensen met de desbetreffende opleidingsachtergrond werkzaam zijn, als van verschuivingen in de gevraagde kwalificaties binnen de diverse beroepssegmenten. Tabel 4.6 geeft een overzicht van de opleidingstypen waarvoor een dalende vraag wordt verwacht.

Tabel 4.6

Opleidingstypen met relatief gezien de grootste netto baanvernietiging 1999-2004 (totaal aantal en gemiddeld jaarlijks percentage)

Opleidingstype

VMBO brood en banket VMBO grafische techniek

VMBO landbouw en natuulijke omgeving

NMBO metaal: mechanische techniek

Basisondenvijs

VMBO voertuigentechniek

VMBO bouwtechniek

HBO lerarenopleiding talen

MBO brood en banket

MBO grafische techniek

$\begin{array}{rr}\begin{array}{r}\text { Werkgelegenheidskrimp } \\ \text { aantal }\end{array} & \% \\ & \\ 2.900 & 7,1 \\ 1.800 & 6,1 \\ 18.300 & 6,0 \\ 32.000 & 5,7 \\ 119.600 & 5,3 \\ 9.700 & 4,9 \\ 21.400 & 3,5 \\ 4.500 & 3.3 \\ 2.800 & 3,3 \\ 6.300 & 3,2\end{array}$

Bron: ROA 
Uit de tabel blijkt dat met name voor de lagere opleidingstypen een dalende vraag verwacht wordt. Het is niet verrassend te zien dat het merendeel van de opleidingstypen waarvoor een dalende vraag wordt verwacht betrekking heeft op de technische opleidingen op laag of middelbaar niveau. Werkenden met deze opleidingsachtergronden zijn met name werkzaam in de lagere en middelbare technische beroepen, waarvoor eveneens een dalende werkgelegenheid wordt verwacht. De afname van de vraag is relatief het grootst voor $V M B O$ brood en banket. Het aantal werkenden met deze opleidingsachtergrond zal de komende jaren met gemiddeld $7 \%$ per jaar afnemen. Absoluut gezien kent het aantal werkenden met basisonderwijs de grootste vraagafname. Deze vraagafname heeft betrekking op circa 120.000 mensen, hetgeen een daling van gemiddeld $5 \%$ per jaar is. De enige opleiding op hoger niveau waarvoor een vraagafname wordt verwacht is $H B O$ lerarenopleiding talen, waarvoor de vraag met gemiddeld $3,3 \%$ per jaar zal afnemen.

De werkgelegenheid voor mensen met een bepaalde opleidingsachtergrond kan ook in het ene beroep toenemen, terwijl de werkgelegenheid voor mensen met deze opleiding in een ander beroep juist afneemt. Werkenden die hun baan verliezen, kunnen zich dan genoodzaakt zien uit te wijken naar een ander beroep. In dat geval kan er ook kwalificatieveroudering optreden, omdat de vereiste kennis en vaardigheden tussen de beroepen verschillen.

Tabel 4.7 geeft een beeld van de opleidingsrichtingen waarvoor de reallocatie in absolute $z$ in het grootst is ${ }^{29}$. De reallocatie van de werkgelegenheid is het grootst voor cen aantal opleidingsrichtingen op lager en middelbaar niveau. Voor de werkenden met een opleiding $M B O$ economie wordt in absolute zin de grootste reallocatie van de werkgelegenheid verwacht. Ruim 40.000 werkenden met deze opleidingsachtergrond zullen uit moeten wijken naar andere beroepen waardoor ze het risico lopen op kwalificatieveroudering.

\section{Tabel 4.7}

\section{Opleidingsrichtingen met de grootste reallocatie in de periode 1999-2004 (totaal en gemiddeid jaarlijks percentage)}

$\begin{array}{lrr}\text { Opleidingsrichting } & \text { aantal } & \% \\ \text { MBO economie } & 41.300 & 0,9 \\ \text { MBO techniek } & 34.700 & 0,8 \\ \text { VMBO theorie } & 27.700 & 1,2 \\ \text { VMBO zorg en welzijn } & 26.300 & 2,5 \\ \text { Basisonderwijs } & 20.000 & 0,8 \\ \text { MBO dienstverlening en gezondheidszorg } & 17.200 & 0,5 \\ \text { VMBO techniek } & 16.500 & 0,7 \\ \text { HBO techniek } & 16.400 & 1,5 \\ \text { VMBO economie } & 16.300 & 1,9 \\ \text { HAVONWO } & 9.900 & 0,6\end{array}$

Bron: ROA

29) Zie tabel 4.8 in de Statistische Bijlage voor een volledig overzicht van de reallocatie per opleidingsrichting. 
Wanneer tabel 4.7 wordt vergeleken met de opleidingsrichtingen met de grootste netto baanvernietiging valt op dat werkenden met alleen basisonderwijs of een opleiding $V M B O$ economie of $V M B O$ techniek zowel geconfronteerd worden met krimpende werkgelegenheid in het algemeen als met een reallocatie van de werkgelegenheid 30 . De werkenden met deze opleidingsachtergrond hebben dan ook een aanzienlijk risico op het verlies van werk als gevolg van kwalificatieveroudering veroorzaakt door ontwikkelingen op de arbeidsmarkt.

Het is mogelijk dat er voor werkenden met een bepaalde opleidingsachtergrond in een bepaald beroepssegment een afnemende vraag wordt verwacht, terwijl er voor werkenden met diezelfde opleidingsachtergrond in een ander beroepssegment een toename van de vraag wordt verwacht. Het is nuttig te weten in welke beroepssegmenten deze werkenden het risico lopen hun baan te verliezen vanwege kwalificatieveroudering als gevolg van ontwikkelingen op de arbeidsmarkt. Daarom wordt in tabel 4.8 een overzicht gegeven van de beroepssegmenten waarin een vraagafname wordt verwacht voor opleidingstypen waarvoor een negatieve uitbreidingsvraag wordt verwacht ${ }^{31}$.

Tabel 4.8

Verwachte relatieve vraagafname per beroepssegment voor opleidingstypen waar sprake is van baanvernietiging, 1999-2004

\section{Opleidingstype}

Basisonderwijs

Elementaire beroepen

Lagere agrarische beroepen

Lagere technische beroepen

Lagere transportberoepen

Lagere verzorgende beroepen

Middelbare agrarische beroepen

Middelbare technische beroepen

Middelbare transportberoepen

Middelbare administratieve, commerciële beroepen

Middelbare verzorgende beroepen

VMBO landbouw en natuurlijke omgeving

Lagere agratische beroepen

Lagere lechnische beroepen

Middelbare agrarische beroepen

VMBO bouwtechniek

Liggere lechnische beroepen

Middelbare technische beroepen

VMBO metaal: mechanische techniek

Lagere technische beroepen

Middelbare lechnische beroepen

Middelbare administratieve, commerciële beroepen

\section{$\%$}

15

25

41

27

15

47

43

77

28

34

37

60

37

24

18

38

30

37

30 Zie tabel t.7 in de Statistix be Bijlage voor een volledig overzicht van de ontwikkeling van de werkgelegenheid per opleidingsrichting.

31 Zie tabel 4.9 in de Satistische Bijlage voor een volledig overzicht van de relatieve hijdrage van beroperegmenten an de vratgontwikteling per opleidingstype. 
Tabel 4.8 (vervolg) Verwachte relatieve vraagafname per beroepssegment voor opleidingstypen waar sprake is van
baanvernietiging, 1999-2004

Opleidingstype

$\%$

VMBO voertuigentechniek

Lagere technische beroepen

60

38

VMBO transport en logistiek

Lagere transportberoepen

VMBO administratie, handel en mode

Lagere technische beroepen

Lagere verzorgende beroepen

Middelbare technische beroepen

Hogere administratieve, commerciele, economische beroepen

\author{
60
}

36

87

75

VMBO (uiterlijke) verzorging

Lagere agrarische beroepen

Lagere technische beroepen

Lagere verzorgende beroepen

56

74

37

MBO werktuigbouw en mechanische techniek

Middelbare technische beroepen

Hogere technische beroepen

$\mathrm{MBO}$ grafische techniek

Lagere technische beroepen

36

Middelbare technische beroepen

28

Bron: ROA

Uit tabel 4.8 blijkt dat de vraag naar werkenden met slechts basisonderwijs in een groot aantal beroepssegmenten naar verwachting zal dalen. Het betreft hier voornamelijk beroepssegmenten op lager en middelbaar niveau. De vraagafname is relatief het grootst in de middelbare transportberoepen. Verder blijkt dat de relatieve vraagafname van een aanzienlijk aantal opleidingstypen zich voor een groot deel voordoet in de lagere tecbnische beroepen. Dat is onder meer het geval bij de opleidingstypen VMBO landbouw en natuurlijke omgeving, VMBO administratie, bandel en mode en VMBO voertuigentechniek.

Ook wanneer de vraag naar werkenden met een bepaalde opleidingsachtergrond stijg1, is het mogelijk dat in een aantal beroepssegmenten toch een vraagdaling naar werkenden met de desbetreffende opleidingsachtergrond optreedt. Uit tabel $4.9 \mathrm{komt}$ naa voren dat een relatieve vraagafname bij deze opleidingstypen zich veelal in een beperkt aantal beroepssegmenten voordoet, maar dat de vraagafname op het desbetreffende segment wel aanzienlijk kan zijn. Voor werkenden met een opleidingsachtergrond $H B O$ maatscbappelijk werk en bulperlening is de relatieve vraagafname het grootst in de bogere (para)medische beroepen. Voor werkenden met een diploma VMBO theoric daarentegen doet zich in een viertal beroepssegmenten een daling van de vraag vonr. De relatieve vraagafname is met $18 \%$ het grootst in de middelbare techniscbe beroepen. 
Ook voor werkenden met een opleiding $M B O$ bandel doet zich naar verwachting in een viertal beroepssegmenten een vraagafname voor. In de lagere technische beroepen zal die relatieve vraagafname naar verwachting het grootst zijn.

Tabel 4.9

Verwachte relatieve baanvernietiging per beroepssegment voor opleidingstypen waar sprake is van baancreatie, 1999-2004

\section{Opleidingstype}

\section{VMBO theorie}

Lagere technische beroepen

Lagere transportberoepen

Middelbare technische beroepen

Middelbare administratieve, commerciële beroepen

HAVO/VWO

Middelbare (para)medische beroepen

MBO landbouw en veeteelt

Middelbare administratieve, commerciële beroepen

$M B O$ verpleging

Middelbare (para)medische beroepen

Hogere (para)medische beroepen

MBO administratie

Middelbare transportberoepen

Hogere administratieve, conmmerciële, economische beroepen

MBO handel

Lagere technische beroepen

Middelbare techniische beroepen

36

Middelbare administratieve, commerciële beroepen

21

Hogere administratieve, commerciële, economische beroepen

HBO accountancy en bedrijfseconomie

Middelbare administratieve, commerciële beroepen

HBO bedrijfskunde

Managers (wetenschappelijk weck- en denkniveau)

HBO maatschappelijk werk en hulpverlening

Hogere (para)medische beroepen

$\mathrm{HBO}$ uitvoerende en beeldende kunsten

Hogere pedagogische beroepen

Bron: ROA

\section{Risico-verhogende factoren}

Zoals reeds is aangegeven, lopen werkenden met een flexibel dienstverband een groter risico op het verlies van werk als gevolg van kwalificatieveroudering door de ontwik- 
kelingen op de arbeidsmarkt. Voor de arbeidsmarktsegmenten met krimpende werkgelegenheid is daarom nagegaan in hoeverre er sprake is van deze risico-verhogende factor. In figuur 4.1 is het verband weergegeven tussen de werkgelegenheidsontwikkeling en het percentage werkenden met een flexibel dienstverband. Vak I heeft betrekking op de bedrijfssectoren met een krimpende werkgelegenheid en een meer dan gemiddeld percentage werkenden met een flexibel dienstverband. Dit is het geval in de sectoren landbouw en visserij en voeding. In deze sectoren is er derhalve een relatief grote groep werkenden met een verhoogd risico op baanverlies als gevolg van kwalificatieveroudering. Ook in de boreca en zakelijke dienstverlening is het percentage flexwerkers relatief hoog. In deze sector zal de werkgelegenheid naar verwachting echter de komende jaren sterk toenemen, waardoor het risico op verlies van werk voor mensen met een flexibel arbeidscontract in principe niet groot is.

\section{Figuur 4.1}

Werkgelegenheidsontwikkeling en flexwerk naar sector

Percentage flexibel werkenden

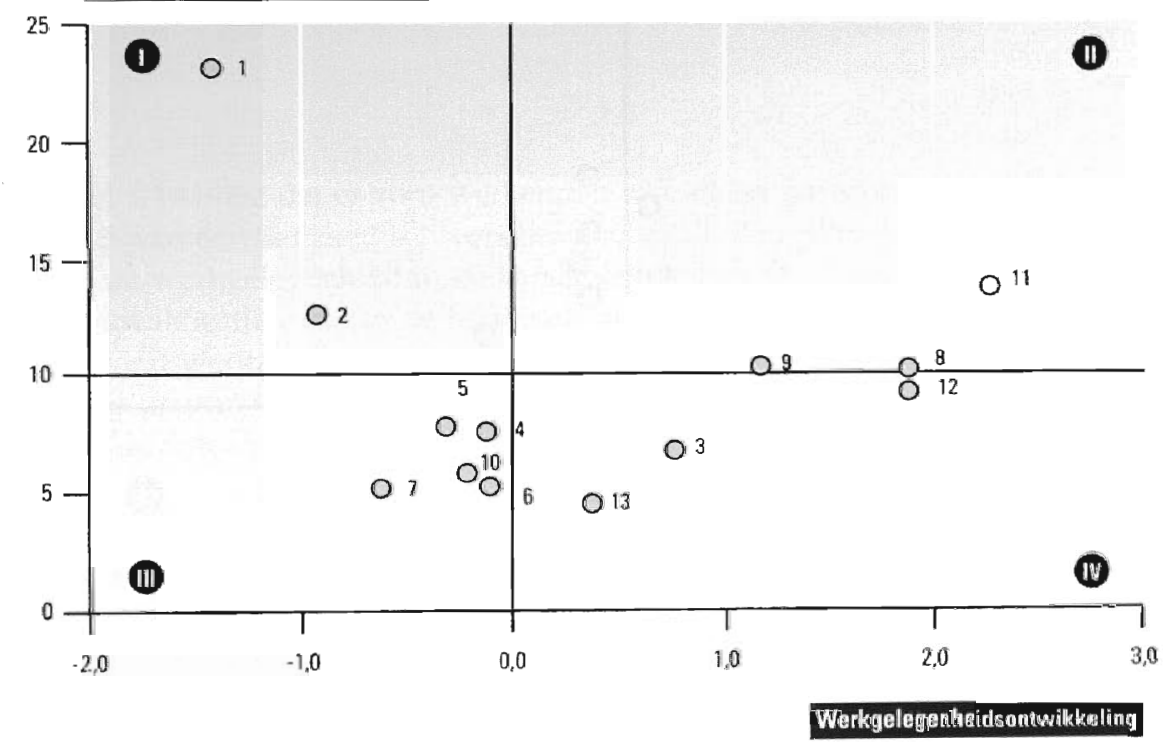

1 Landbouw en visserij

2 Voeding

3 Chemie

4 Metaal-en elektrotechniek

5 Overige industrie

6 Energie

7 Bouw en onroerend goed
8 Handel en reparatie

9 Transport en communicatie

10 Bank-en verzekeringswezen

11 Horeca en zakelijke dienstverlening

12 Kwartaire diensten

13 Overheid en onderwijs

Bron: CBS/ROA 
Ook voor de beroepssegmenten is nagegaan in welke beroepssegmenten met een krimpende werkgelegenheid er sprake is van een hoog percentage werkenden met een flexibel arbeidscontract. Figuur 4.2 laat zien dat dit met name het geval is in de lagere beroepen: lagere niet-specialistiscbe beroepen (bv. ondersteunende administratieve bulpkracbten), lagere agrariscbe beroepen, lagere verzorgende beroepen en lagere (para)medische beroepen (bv. verpleegbulpen en leerling-verpleegkundigen) .

\section{Figuur 4.2}

\section{Werkgelegenheidsontwikkeling en flexwerk naar beroep}

\section{Percentage flexibel werkenden}

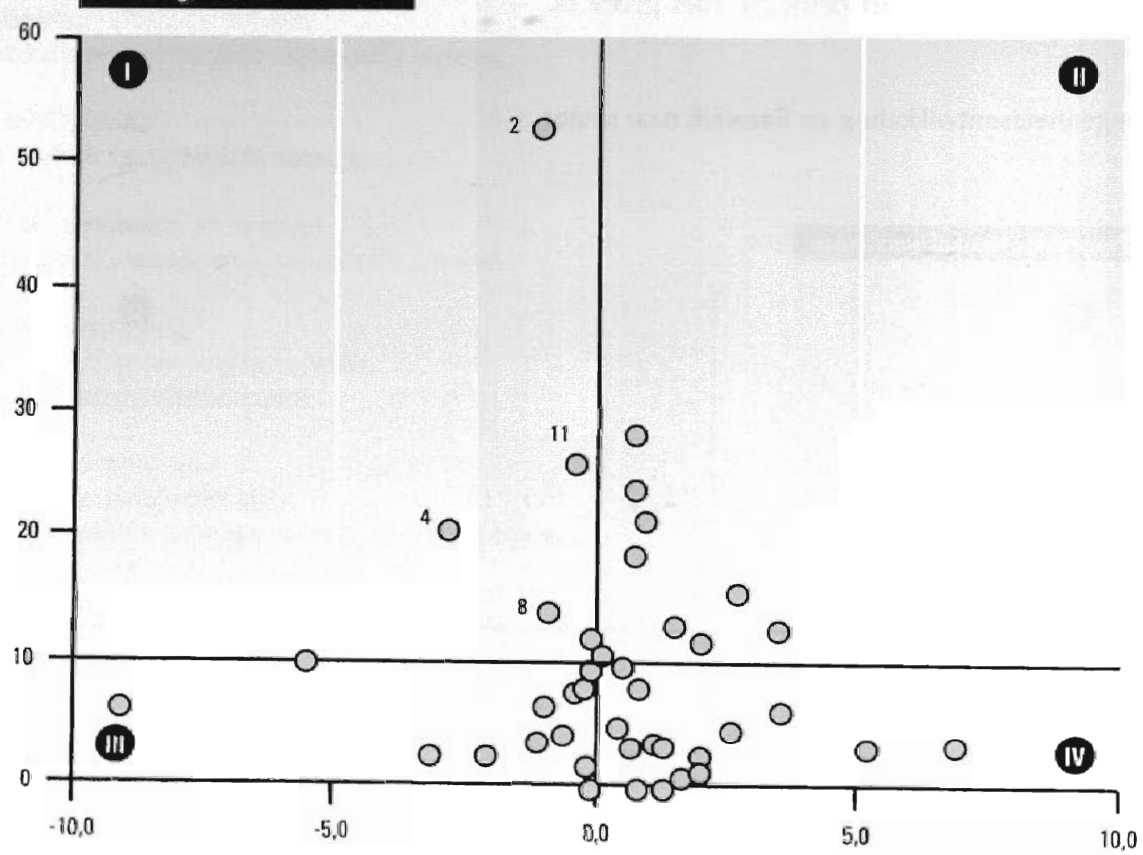

\footnotetext{
2 Lagere niet-specialistische beroepen

4 Lagere agrarische beroepen

8 Lagere (para)medische beroepen

11 Lagere verzorgende beroepen

Overige beroepen
}

\section{Bron: CBS/ROA}

Wanneer gekeken wordt naar opleidingsachtergrond van de werkenden komt naar voren dat er ook met name bij de lager opgeleiden sprake is van een risico op het verlies van werk vanwege de krimpende werkgelegenheid en een hoog percentage werkenden met een flexibel arbeidscontract. Werkenden met basisonderwijs, VMBO administratie, bandel en mode, VMBO consumptief en levensmiddelentechniek, VMBO (uiterlijke) verzorging en MBO sociaal-cultureel vormen de bedreigde groep. 


\subsection{Functie-inhoudelijke kwalificatieveroudering}

Zoals reeds eerder aangegeven kan functie-inhoudelijke kwalificatieveroudering worden veroorzaakt door een upgrading van de opleidingseisen in een bepaald beroep. Aan deze upgrading liggen verschillende oorzaken ten grondslag. De toenemende internationalisering en de mede daaruit voortvloeiende organisatorische veranderingen, de snelle technologische ontwikkeling en de toegenomen aandacht voor kwaliteitszorg spelen hierbij een belangrijke rol.

Tabel 4.10

Uitbreidingsvraag per opleidingsniveau vanwege de upgrading van de kwalificatie-eisen (netto-effecten), 1999-2004

Opleidingsniveau

Upgradingseffect $\%$

Basisondervijs

VMBO

$-7,4$

HAVO/WO, MBO

3,7

$\mathrm{HBO}$

6,4

WO

Bron: ROA

Uit tabel 4.10 blijkt dat er voor werkenden met alleen basisonderwijs en VMBO-niveau sprake is van een aanzienlijke werkgelegenheidskrimp vanwege een teruglopend aandeel in de werkgelegenheid in de verschillende beroepen. Dit wijst op een upgrading van de kwalificatie-eisen in de beroepen waar degenen met een dergelijke opleidingsachtergrond werkzaam zijn. De werkenden op $M B O-, H B O-$ en WO-niveau profiteren van deze upgrading van de kwalificatie-eisen. In tabel 4.11 wordt een overzicht gegeven van de opleidingstypen die het meest te lijden hebben van de toenemende eisen die

Tabel 4.11

Opleidingstypen die het meest te lijden hebben van de upgrading van opleidingseisen, 1999-2004

Opleidingstype

Upgradingseffect

VMBO brood en banket

Basisonderwijs

VMBO landbouw en natuurlijke omgeving

$-22$

VMBO handel, administratie en mode

$-21$

VMBO grafische techniek

VMBO voertuigentechniek

HBO lerarenopleiding talen

$-18$

VMBO metaal: mechanische techniek

$-16$

VMBO transport en logistiek

.14

$\mathrm{MBO}$ verzorging

Bron: ROA 
werkgevers in veel beroepen zullen stellen ${ }^{32}$. Het is niet verrassend dat deze tabel voornamelijk opleidingstypen op VMBO-niveau bevat. Werkenden met de opleidingsachtergrond VMBO brood en banket en degenen met slechts basisonderwijs hebben het sterkst te lijden van de upgrading van de kwalificatie-eisen in de beroepen waar men traditioneel emplooi vindt. Als gevolg van toenemende opleidingseisen in deze beroepen zal de vraag de komende vijf jaar met (bijna) een kwart afnemen. De tabel vertoont veel overeenkomsten met het overzicht van opleidingen waarvoor over de periode 19972002 een sterk negatief opleidingseffect werd verwacht. Niet alleen worden veelal dezelfde opleidingen genoemd, ook de grootte van de opleidingseffecten komt sterk overeen.

\section{Risico-verhogende factoren}

Zoals reeds is aangegeven lopen vooral oudere werknemers aanzienlijke risico's hun baan te verliezen als gevolg van functie-inhoudelijke kwalificatieveroudering. Bovendien zullen zij, als zij hun baan verliezen, veel meer moeite hebben om een nieuwe baan te vinden in hetzelfde beroep, wanneer hun kwalificaties niet meer aansluiten bij de kwalificaties die tegenwoordig vereist zijn. Om dit risico in beeld te brengen zal hier nader worden ingegaan op de mate waarin het opleidingsniveau van ouderen afwijkt van het opleidingsniveau van alle werkenden binnen een beroep

Tabel 4.12

Oververtegenwoordiging van ouderen (50-64 jaar) met een bepaald opleidingsniveau ten opzichte van alle werkenden naar beroepsgroep, 1997-1998

\begin{tabular}{|c|c|c|}
\hline $\begin{array}{c}\text { Basis- } \\
\text { onderwijs }\end{array}$ & VMBO & $\begin{array}{c}\text { HAVO/VWO } \\
\text { MBO }\end{array}$ \\
\hline
\end{tabular}

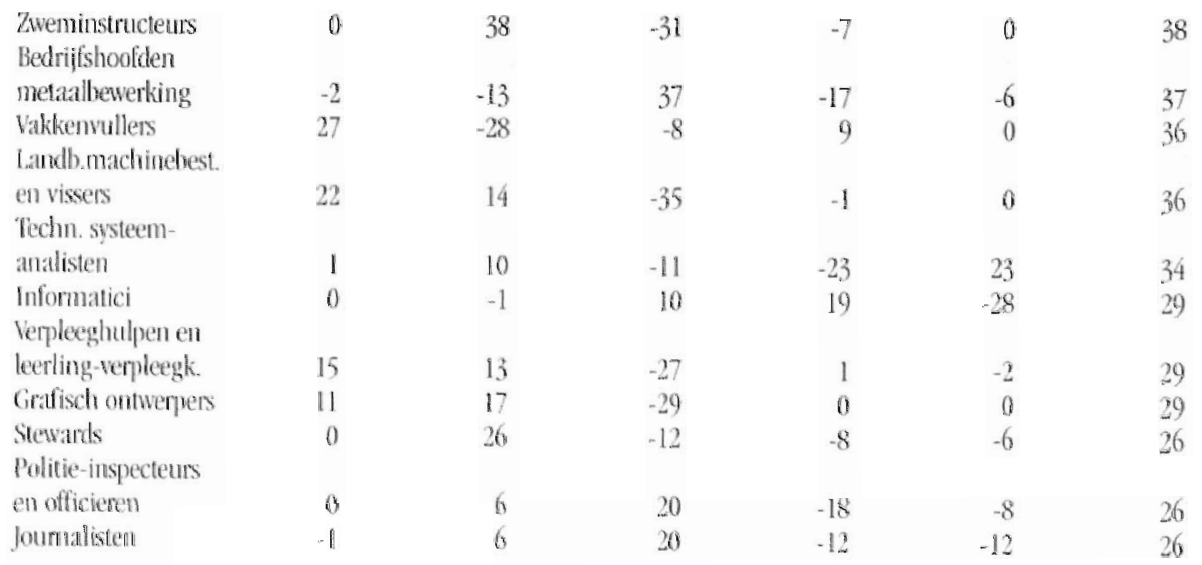

Bron: CBS/ROA

In tahel 4.12 wordi een overzicht gegeven van de oververtegenwoordiging van ouderen met een bepald opleidingsniveau ten opzichte van alle werkenden in de desbe-

32 Zie tahet +10 in de Shatistische Bijlage vor een wolledig overzicht. 
treffende beroepsgroep 33 . Per beroepsgroep is steeds het verschil wcergegeven tussen het percentage ouderen met een bepaald opleidingsniveau en het gemiddelde percentage werkenden met dat opleidingsniveau. Zo is in de beroepsgroep zweminstructeurs het percentage ouderen met een opleiding op VMBO-niveau 38\%-punt hoger dan gemiddeld. De laatste kolom geeft het totaal van de oververtegenwoordiging van ouderen met een bepaald opleidingsniveau in de desbetreffende beroepsgroep aan. In de tabel zijn alleen de beroepsgroepen opgenomen waarvoor de totale oververtegenwoordiging groter is dan 25\%. De meerderheid van de vermelde beroepen zijn beroepen op lager en middelbaar niveau. Met name in deze beroepen zijn de ouderen oververtegenwoordigd op de lagere opleidingsniveaus. Dit bevestigt het vermoeden dat de oudere werkenden in veel beroepen een lager kwalificatieniveau hebben dan de jongeren. Dit vergroot vanzelfsprekend het risico dat ouderen het eerst hun baan zullen verliezen wanneer er sprake is van een krimpende werkgelegenheid of een sectorale reallocatie van werkgelegenheid in een bepaald beroep.

\subsection{Conclusies.}

In dit hoofdstuk is gekeken naar de ontwikkelingen op de arbeidsmarkt die kunnen leiden tot kwalificatieveroudering. De belangrijkste uitkomsten zijn nog eens samengevat in tabel 4.13 .

Het risico op baanverlies als gevolg van kwalificatieveroudering vanwege de ontwikkelingen op de arbeidsmarkt is met name groot voor werkenden in de sector landbou en visserij en de conjuncturgevoelige bouw en industriële sectoren. De beroepssegmenten waarvoor een groot risico op baanverlies als gevolg van kwalificatieveroudering bestaat, zijn dan ook met name de agrarische en technische beroepen op laag en middelbaar niveau. Wanneer gekeken wordt naar de opleidingsachtergrond van de werkenden zijn het met name laaggeschoolden met een technische opleiding die een groot risico hebben hun baan te verliezen als gevolg van kwalificatieveroudering.

Werkenden met een flexibel dienstverband in de sectoren landbouw en visserij, voeding en boreca en zakelijke dienstwertening hebben een vethoogd risico op het verlies van hun baan als gevolg van kwalificatieveroudering. Dat gelde eveneens voor werkenden in een aantal beroepen op lager niveau en werkenden met slechts basisonderwijs of cen aantal opleidingen op $V M B O$-niveau.

Daarnaast hebben laaggescboolden met een technische opleiding te kampen met cen risico op baanverlies als gevolg van de functie-inhoudelijke kwalificatieveroudering vanwege de upgrading van de opleidingseisen in de beroepen waar men werkzaam is. Dat geldt eveneens voor werkenden met slechts basisonderwijs.

Ouderen die lager zijn opgeleid dan het gemiddeld opleidingsniveau in hun beroep, hebben een verhoogd risico op het verlies van hun baan als gevolg van kwalificaticveroudering vanwege de upgrading van de kwalificatie-eisen. Het betreft hier vectall lagere en middelbare beroepen op zeer diverse terreinen.

33 Zie voor een volledig overzicht van de oververtegenwoordiging van ouderen met een lepald opleidingsniveau naar beroepsgroepen tahel 4.5 in de Statistische Bijlage. 
Tabel 4.13

Belangrijkste segmenten met een hoog risico op kwalificatieveroudering vanwege arbeidsmarktontwikikelingen

Risicodimensie

Kwalificatieveroudering door marktontwikkelingen

Dalende werkgelegenheid/dalende vraag

Bedrifssectoren

Beroepen

Opleidingen

Reallocatie

Beroepen
Risicogroep

Landbouw en visserij

Voeding

Metaal en elektrotechniek:

Overige industrie

Energie

Bouw en onroerend goed

Bank- en verzekeringswezen

Lagere niet-specialistische beroepen

Lagere agrarische beroepen

Lagere technische beroepen

Lagere (para)medische beroepen

Lagere verzorgende beroepen

Middelbare agrarische beroepen

Middelbare wiskundige, natuurw.

Middelbare technische beroepen

Hogere pedagogische beroepen

Hogere technische beroepen

Basisonderwijs

VMBO landbouw en natuurlijke omgeving

VMBO bouwtechniek

VMBO metaal: mechanische fechniek

VMBO voertuigentechniek

VMBO grafische techniek

VMBO brood en banket

MBO grafische techniek

MBO brood en banket

HBO lerarenopleiding talen

Elementaire beroepen

Lagere agrarische beroepen

Lagere technische beroepen

Lagere administratieve, commerciële beroepen

Lagere verzorgende beroepen

Middelbare agrarische beroepen

Middelbare technische beroepen

Middelbare transportberoepen

Hogere technische beroepen

Hogere administratieve, conmerciële, econo-

mische beroepen

Hogere taalkundige, culturele beroepen 
Tabel 4.13 (vervolg)

Belangrijkste segmenten met een hoog risico op kwalificatieveroudering vanwege arbeidsmarktontwikkelingen

Risicodimensie

Opleidingen

Flexibel dienstverband

Bedriffssectoren

Beroepen

Opleidingen

Functie-inhoudelijke kwalificatieveroudering

Negatief upgradingseffect

Opleidingen
Risicogroep

Basisondenwijs

VMBO theorie

VMBO techniek

VMBO economie

VMBO zorg en welzijn

HAVO/WWO

MBO techniek

MBO dienstverlening en gezondheidszorg

MBO economie

HBO techniek

Landbouw en visserij

Voeding

Horeca en zakelijke dienstverlening

Lagere niet-specialistische beroepen

Lagere agrarische beroepen

Lagere (para)medische beroepen

Lagere verzorgende beroepen

Basisonderwijs

VMBO administratie, handel en mode

VMBO consumptief en levensmiddelen-

techniek

VMBO (uiterlijke) verzorging

MBO sociaal-cultureel

Basisonderwijs

VMBO landbouw en natuurlijke omgeving

VMBO metaal: mechanische techniek

VMBO voertuigentechniek

VMBO grafische techniek

VMBO brood en banket

VMBO transport en logistiek

VMBO administratie, handel en modc

MBO verzorging

HBO lerarenopleiding talen 
Tabel 4.13 (vervolg)

Belangrịkste segmenten met een hoog risico op kwaificatieveroudering vanwege arbeidsmarktontwikkelingen

Risicodimensie

Lager opgeleide ouderen

Beroepen

Bron: ROA
Risicogroep

\author{
Zweminstructeurs \\ Bedriffshoofden metaalbewerking \\ Vakkenvullers \\ Landbouwmachinebestuurders en vissers \\ Technisch systeemanalisten \\ Informatici \\ Verpleeghulpen en leerling-verpleegkundigen \\ Grafisch ontwerpers \\ Stewards \\ Politie-inspecteurs en officieren \\ Journalisten
}




\section{Scholing en functionele flexibiliteit}

\subsection{Inleiding}

Om het risico van kwalificatieveroudering als gevolg van technologische, organisatorische en arbeidsmarktontwikkelingen zoveel mogelijk te beperken staat werkenden een aantal wegen open. Een van de belangrijkste manieren om de negatieve gevolgen van kwalificatieveroudering te beperken is het volgen van additionele scholing. Scholing heeft betrekking op intentionele activiteiten die als doel hebben de competenties van werkenden op peil te houden of te vergroten. Hierbij gaat het niet alleen om formeel georganiseerde cursussen, workshops en bedrijfsopleidingen maar ook om bijvoorbeeld instructie of begeleiding tijdens het werk ('on the job training'). Ervaringsleren ('learning by doing') wordt niet als scholing beschouwd, omdat het verwerven van kwalificaties hier niet het doel is van de verrichtte activiteit, waardoor vooraf ook nielt duidelijk is wat er geleerd gaat worden.

In Scholing van werkenden (De Grip c.s., 1999) wordt uitvoerig ingegaan op de effecten en betekenis van scholing voor zowel werknemers als werkgevers. Een van de effecten van scholing is dat het kwalificatieveroudering voorkomt of oplost. Door scholing kan immers een dreigende kwalificatie-achterstand worden voorkomen of een bestaande achterstand verdwijnen. Wanneer een eenmaal opgelopen kwalificatieachterstand moet worden weggewerkt is er sprake van curatieve scboling. Vaak gaat het daarbij om (substantiële) bijscholing. Om een achterstand te voorkomen (preventie) wordt doorgaans vooral in kortdurige scholingsactiviteiten geparticipeerd. In veel bedrijven worden hiertoe bijvoorbeeld lezingen, workshops en georganiseerde groepsdiscussies verzorgd (Waterreus, 1997). Dergelijke activiteiten houden niet altijd direct verband met het eigenlijke werk van mensen, mar zij bevorderen vooral het algemene kennisniveau, wat mogelijk ook de aandacht voor ontwikkelingen in de matschappij vergroot. Bovendien bevorderen dergelijke activiteiten de onderlinge discussie, de communicatie en de vaardigheden op deze gebieden.

Scholing heeft bovendien positieve effecten op de productiviteit van bedrijven als geheel en op de bedrijfsresultaten in het bijzonder (Cörvers, 1994). Analyses van Bartel (1991) maken duidelijk dat de productiviteit van bedrijven duidelijk wordt beinvloed door de mate waarin men scholing aanbiedt. Bedrijven met een relatief lage productiviteit, die flink investeren in nieuwe scholingsprogramma's zien duidelijk sterkere productiviteitsstijgingen dan vergelijkbare bedrijven die nauwelijks met scholing bezig zijn. Onderzoek van Bentlage c.s. (1989) makt hovendien duidelijk dat deze productiviteitsstijgingen ook de bedrijfsresultaten positief beïnvloeden. Met name korte, regelmatige scholing blijkt bij te dragen aan de bedrijfsresultaten.

Naarmate kennis meer als concurrentiemiddel wordt aangewend is het dus ook voor werkgevers van toenemend belang om fors te investeren in menselijk kapitaal. De overgang naar een kenniseconomie (zie ook: Kessels, 1996) in combinatie mel de verkrapping op de arbeidsmarkt maakt investeren in menselijk kapitaal zelfs onontkombaar. Bovendien wordt de arbeidsmarkt door de toenemende krapte steeds meer een buyers- 
market, waardoor bedrijven alles in het werk moeten stellen om als werkgever aantrekkelijk te blijven. Een van de methoden om als werkgever aantrekkelijk te zijn en aldus aan voldoende gekwalificeerd en getalenteerd personeel te komen is het aanbieden van uitstekende ontplooiingsmogelijkheden. Niet voor niets wordt in veel advertenties naast een goed salaris melding gemaakt van goede ontwikkelingsmogelijkheden. Wanneer ontwikkelingsmogelijkheden worden genoemd gaat het overigens niet uitsluitend om mogelijkheden om hogerop te komen in een organisatie. Ook horizontale mobiliteit en functieverbreding behoren entoe. In dit hoofdstuk worden de mogelijkheden die werkenden hebben om hun horizon te verbreden gezien als een aspect van de functionele flexibiliteit van werkenden.

De toenemende aandacht voor functionele flexibiliteit komt voort uit een toenemende behoefte van werknemers aan grotere taak- en functiewisselingen, alsmede uit de toenemende behoefte van werkgevers om te kunnen inspelen op in de toekomst benodigde kwalificaties (Thijssen, 1997). Naast een grote scholingsbereidheid wordt van werkenden een voortdurende bereidheid verwacht zich flexibel op te stellen, zowel qua werktijden als werkinhoud. Flexibele inzetbaarheid heeft zowel voor werkenden als voor werkgevers een aantal duidelijke voor- en nadelen. Werkgevers betalen breed inzetbare werkenden meer loon en krijgen daar een slagvaardig personeelsbestand voor terug. Werkenden merken dat de werkbelasting toeneemt en ondervinden meer moeilijkheden bij het opbouwen van duurzame contacten met collega's. Een afwisselende baan, een hoger salaris, meer ontwikkelingsmogelijkheden en een verbeterde positie op de externe arbeidsmarkt staan hier tegenover (Glasbergen, 1994). Met name dit laatste voordeel makt het bevorderen van de functionele flexibiliteit interessant met het oog op de centrale doelstelling van dit rapport, namelijk het voorkomen van verlies van werk als gevolg van kwalificatieveroudering. Het bevorderen van de brede inzetbaarheid van werkenden draagt ertoe bij dat werkenden niet alleen op de interne arbeidsmarkt waardevol zijn maar ook op de externe. De functioneel flexibele werkenden zijn vaak interessant, omdat zij zowel intern als extern op meerdere plaatsen hun waarde kunnen hebben.

In veel grote bedrijven wordt al geruime tijd gebruik gemaakt van interne uitzendbureaus, mobiliteitscentra en arbeidspools om de flexibiliteit van werkenden te vergroten. Deze mobiliteitsbevorderende activiteiten hebben niet alleen het doel overtollige werkenden elders aan de slag te krijgen en te houden, maar ook om voor de nodige doorstroming, opleiding en ontwikkeling van de werkenden van het bedrijf te zorgen. Zo waren de eerste groepen werkenden die zich voor de flexpool van ABP/USZO aanmeldden bijvoorbeeld louter enthousiastelingen, die niet op één plek wilden blijven zitten. Het is dan ook nu nog steeds mogelijk vrijwillig tot de flexpool toe te treden als werkenden behoefte hebben aan doorstroming. Afhankelijk van hun capaciteiten en hun specifieke expertise wordt bekeken waar werkenden het beste kunnen worden ingezet. Interessant in dit verband is bijvoorbeeld ook de opzet van Stork Mobiel. Dit bedrijfsonderdeel van de Stork fabrieken organiseert niet alleen personele bewegingen tussen werkmaatschappijen maar ook tussen Stork en de externe arbeidsmarkt. Bovendien leidt Stork Mobiel haar personeel op middels om-, her-, en bijscholing (Nordbeck, 1998), Verspreid over dit hoofdstuk wordt aan deze en andere bemiddelingsinstanties nog wat meer aandacht besteed. 
De verdere opzet van dit hoofdstuk is als volgt. In paragraaf 5.2 worden de belangrijkste cijfers en trends met betrekking tot de participatie in scholingsactiviteiten besproken. In paragraaf 5.3 worden de cijfers over scholing verbijzonderd naar bedrijfsgrootte, bedrijfssector, beroep en opleiding. In paragraaf 5.4 wordt vervolgens een overzicht gegeven van de functionele flexibiliteit van werkenden, ditmaal verbijzonderd naar bedrijfssector, beroep en opleiding. In paragraaf 5.5 passeren de belangrijkste resultaten van de in dit hoofdstuk uitgevoerde analyses nog eens kort de revue.

\subsection{Enkele feiten en cijfers over scholingsinspanningen}

Jaarlijks volgen meer dan één miljoen werkenden een bedrijfsopleiding en besteden bedrijven en overheidsinstellingen volgens een voorzichtige schatting circa $f 7$ miljard aan scholing van hun personeel. Het grootste deel van deze uitgaven wordt besteed aan de verdere scholing van hoger opgeleiden (De Vos, 1999). De toename van het aantal gevolgde bedrijfsopleidingen is de afgelopen jaren wat gestagneerd, met name voor de hoger opgeleiden. Nam in 1995 nog ruim 35\% van de hoger opgeleide werkenden deel aan een bedrijfsopleiding, in 1998 was dat nog mar 25\% (De Vos, 1999). In de periode 1996-1998 heeft iets meer dan 40\% van alle werkenden één of meer cursussen gevolgd. Het gemiddelde aantal cursussen dat in dezelfde periode door deze groep werkenden werd gevolgd bedraagt ongeveer 2,3 .

Tabel 5.1 maakt duidelijk dat het steeds vaker de werknemer zelf is die scholingsactiviteiten bekostigt. In bijna 13\% van de gevallen krijgt men geen enkele financiële steun van de werkgever. In 1996 was dat slechts bij 10\% het geval. Blijkbaar nemen werknemers steeds meer van de kosten over van werkgevers. Of dit een gevolg is van het feit dat werkgevers minder bereid zijn mee te betalen, of dat werkenden steeds meer op eigen houtje scholingsactiviteiten ontplooien, wordt niet direct duidelijk uit de beschikbare cijfers. Ook andere financieringsbronnen nemen de financiële steun voor scholingsactiviteiten van de werkgever over. Zo neemt het percentage van de scholingsactiviteiten van werkenden dat door arbeidsbureaus wordt bekostigd iets toe. Niettemin ligt dit percentage nog erg laag. Opmerkelijk is ook de relatief sterke toename van de financiële steun voor scholingsactiviteiten uit andere bronnen. Hierbij gat het onder andere om O\&O-fondsen en overheidssubsidies.

\section{Tabel 5.1}

Financiële steun voor de werknemer bij de bekostiging van scholingsactiviteiten, 1997

Financieringsbron 
Tabel 5.2 geeft wat meer inzicht in wie er zoal opleidingen volgen. Wat het eerst opvalt is dat het met name werkenden zijn in de middelste leeftijdscategorieën die relatief vaak cursussen volgen. In de leeftijdscategorie 25 tot en met 44 jaar heeft bijna $50 \%$ in de periode 1996-1998 één of meerdere cursussen gevolgd. De categorie werkenden in de leeftijd 56-65 jaar participeert daarentegen het minst in scholingsactiviteiten. Iets meer dan een kwart van hen volgde in de periode 1996-1998 één of meerdere cursussen. Het gemiddelde aantal cursussen dat werkenden volgen verschilt nauwelijks per leeftijdscategorie. Opvallend genoeg volgen de jongste werkenden relatief de minste cursussen. In twee jaar tijd gemiddeld 1,8 cursus. Een verklaring hiervoor kan zijn dat deze groep wat vaker langdurige cursussen volgt. Het aantal gevolgde cursussen komt daardoor wat lager te liggen.

Vrouwen lijken op het eerste gezicht minder aan cursussen deel te nemen dan mannen. Van de vrouwen in loondienst heeft $40 \%$ aan één of meerdere cursussen deelgenomen, van de mannen $47 \%$. Mogelijk houdt het feit dat vrouwen nog steeds aanzienlijk meer in deeltijd werken hiermee verband. Wanneer hiervoor wordt gecorrigeerd blijkt dat vrouwen juist vaker aan cursussen deelnemen. Van de vrouwen die parttime werken heeft ruim 34\% in de periode 1996-1998 een of meerdere cursussen gevolgd. Van de mannelijke part-timers deed iets meer dan $30 \%$ dat. Bij de fulltimers is er nauwelijks verschil tussen mannen en vrouwen.

Het gemiddelde aantal cursussen dat vrouwen hebben gevolgd in de periode 1996-1998 ligt wel wat lager dan het gemiddelde aantal cursussen bij mannen. Ook dit kan worden verklaard uit het feit dat vrouwen meer in deeltijd werken, waardoor zij minder tijd en mogelijkheden hebben om aan cursussen deel te nemen. Mannelijke part-timers volgden in de periode 1996-1998 overigens minder cursussen dan vrouwen die werkzaam

Tabel 5.2

Percentage werkenden in loondienst dat in de periode 1996-1998 één of meerdere cursussen heeft gevolgd

\section{Categorie werkenden}

15-25 jaar

26-35 har

$36-45$ jaar

46-55 jatar

56-65 jatr

Mamnen

Vouwen

Partime

Fullime

Tijdeliik

Vast

Tijdelijk met witzicht op vast

Bron: 0SAROA

$\begin{array}{llll}\% & \text { typering } & \begin{array}{c}\text { Aantal } \\ \text { cursussen }\end{array} & \text { typering } \\ 41 & \text { gemiddeld } & 1,8 & \text { erg laag } \\ 52 & \text { hoog } & 2,0 & \text { laag } \\ 44 & \text { gemiddeld } & 1,9 & \text { hoog } \\ 41 & \text { gemiddeld } & 2,0 & \text { gemiddeld } \\ 26 & \text { erg laag } & 1,9 & \text { gemiddeld } \\ & & & \\ 47 & \text { gemiddeld } & 2,0 & \text { hoog } \\ 40 & \text { gemiddeld } & 1,8 & \text { laag } \\ & & & \\ 34 & \text { laag } & 1,7 & \text { erg laag } \\ 44 & \text { gemiddeld } & 2,0 & \text { hoog } \\ 37 & \text { lagg } & & \\ 46 & \text { gemiddeld } & 2,0 & \text { gerg laag } \\ 49 & \text { hoog } & 2,3 & \text { erg hoog }\end{array}$


zijn in een deeltijdfunctie, respectievelijk 1,6 en 1,7 cursussen. Bij de fulltimers zijn het juist de mannen die gemiddeld meer cursussen volgen.

Wanneer wordt gekeken naar het type dienstverband dan blijkt allereerst wederom dat het met name de fulltimers zijn die deelnemen aan cursussen. Niet alleen neemt een groter percentage deel aan cursussen, ook het gemiddelde aantal cursussen dat fulltimers volgen ligt een stuk hoger dan bij de part-timers. Hiervoor is een aantal verklaringen te geven. Allereerst zijn werkgevers minder geneigd geld te steken in de opleiding van part-timers, omdat zij minder uren in de organisatie steken. De terugverdientijd van de trainingsinvestering zal hierdoor langer zijn. Bovendien hebben veel part-timers er bewust voor gekozen in deeltijd te gaan werken, om op die manier tijd vrij te maken voor andere bezigheden, waaronder zorgtaken. Aangezien het volgen van cursussen over het algemeen extra tijd kost gaan part-timers hiertoe waarschijnilijk minder snel over.

Uit de tabel wordt ten slotte duidelijk dat werkenden met een tijdelijk contract veel minder cursussen volgen dan vaste medewerkers. Wanneer de werkenden met een tijdelijke aanstelling echter uitzicht hebben op een vast contract veranderen de zaken. Deze categorie werkenden volgt zelfs meer cursussen dan de werkenden met een vast dienstverband. Het gaat bij deze groep werkenden echter ook deels om werkenden, die nog in opleiding zijn. Ook het gemiddelde aantal cursussen dat deze categorie werkenden volgt ligt aanzienlijk boven dat van de werkenden met een vaste aanstelling

\subsection{Scholingsinsparningen}

\section{Bedrijfsgrootte}

In tabel 5.3 wordt een overzicht gegeven van de scholingsinspanningen van bedriịven verbijzonderd naar bedrijfsgrootte ${ }^{34}$. De percentages in deze tabel liggen veel lager dan in tabel 5.2 omdat hier alleen gekeken is naar de scholingsdeelname op het moment dat de enquete wordt afgenomen. In de tabel wordt een onderscheid gemaakt ussen bedrijfsopleidingen en andere opleidingen. De tabel geeft aan dat de grootste bedrijven

\section{Tabel 5.3}

Percentage werkenden dat deelneemt aan bedrijfsopleidingen en andere opleidingen, naar bedrijfsgrootte, gemiddelde 1997-1998

Bedrijfsgrootte

1-9 werknemers

10-99 werknemers

100 en meer werknemers

Bron: CBS/ROA

$\begin{array}{ll}\text { Bedrijfsopleiding } & \begin{array}{l}\text { Andere opleiding } \\ \% \\ \%\end{array} \\ 2 & 6 \\ 4 & 9 \\ 7 & 8\end{array}$

34 Zie ook de tabellen 5.1 en 5.2 in de Statistische Bijlage: 
het meest aan scholing doen en de kleinste bedrijven het minst. Zowel bij grote als kleine bedrijven is het percentage werkenden dat deelneemt aan bedrijfsopleidingen ten opzichte van 1996 overigens licht toegenomen. Dat impliceert dat het verschil tussen de bedrijfsgrootteklassen constant blijft.

Wat opvalt aan de cijfers die betrekking hebben op andere opleidingen dan bedrijfsopleidingen, is dat werkenden in middelgrote bedrijven iets meer deelnemen aan deze opleidingen dan de werkenden in het grootbedrijf. De hogere deelname aan andere opleidingen komt waarschijnlijk in de eerste plaats doordat middelgrote bedrijven zelf minder mogelijkheden hebben om bedrijfsopleidingen te organiseren, terwijl toch duidelijk de behoefte bestaat het personeel verder te scholen. Werkenden in het kleinbedrijf (1-9 werkenden) nemen daarentegen zowel aan bedrijfsopleidingen als aan andere opleidingen het minst dee!.

Voor het gevonden verband tussen bedrijfsgrootte en het percentage werkenden dat scholing volgt kan een aantal verklaringen worden aangereikt. Een eerste, voor de hand liggende, verklaring is dat er in grotere bedrijven meer geld kan worden vrijgemaakt om werkenden te (laten) scholen. Daarbij komt dat bij veel grote bedrijven ook sprake is van een formeel scholings- en ontwikkelingsplan, waarmee de werkenden binnen bedrijven een kader wordt aangereikt om zichzelf te ontplooien. In steeds meer grotere bedrijven is zelfs sprake van interne opleidingsinstituten. Zo heeft de Rabobank de Rabobank Academie' opgezet, ABP/USZO heeft 'De Academie' en KPN heeft PTT Telecom Opleidingen. Voor grotere bedrijven is het ook gemakkelijker om grotere groepen werkenden in een keer te laten opleiden. Dit levert een aantal belangrijke schaalvoordelen op. Allereerst kunnen leslokalen en apparatuur efficiënter worden gebruikt en kunnen kwantumkortingen gemakkelijker worden bedongen bij opleidingsinstituten. Ook het inschakelen van een instructeur is bij een groter aantal werkenden relatief goedkoper dan voor een klein aantal werkenden.

Een ancler belangrijk voordeel dat grotere bedrijven boven kleinere bedrijven hebben is dat thet opvangen en overnemen van de werkzamheden van degene die aan een cursus deelnemen in grotere bedrijven vaak wat gemakkelijker is dan in kleine bedrijven. Met name in kleinere bedrijven zijn degenen die er werken vaak onmisbaar of onvervangbaar watardoor ze in werktijd niet voor een cursus of opleiding weg kúnnen.

\section{Bedrijfssector}

In talyel 5.4 wordt een overzicht gegeven van de bedriffsectoren waar het meest aan scholingsactiviteiten wordt deelgenomen ${ }^{35}$. In de sector bank-en verzekeringswezen wordt het meeste a an scholing gedaan. In deze sector heeft het 'levenslang leren' zich het opvallendst gemanifesteerd. Zowel voor bedrijfsopleidingen als voor andere opleidingen scoot deze sector het hoogst. Het percentage werkenden dat deelneemt aan bedrijfsopleidingen vertoont bovendien een stijgende tot sterk stijgende trend. De privatisering van onderdelen van her sociale zekerheidsstelsel en de flexibilisering van pensioenen en de daaraan gekoppelde vernieuwing van het productenpakket zijn er

35 Zie ook tabellen 5.5 en 5.6 in de Statistiscbe Billoge. 
waarschijnlijk voor verantwoordelijk dat met name binnen de verzekerings-branche de laatste jaren veel aan scholing is gedaan. Ook in de sector energie wordt door relatief veel werkenden deelgenomen aan bedrijfsopleidingen.

De sectoren overige industrie en landbouw en visserij zijn de sectoren waar het minst aan bedrijfsopleidingen wordt deelgenomen. Binnen de sector landbouw en visserij is dat van oudsher al zo. In deze sector is veelal louter sprake van ervaringsleren. Een andere reden voor de lage scholingsdeelname binnen de sector landbouw en visserij is het nagenoeg ontbreken van opleidings- en ontwikkelingsfondsen die men zou kunnen aanspreken. Er zijn voor de sector als geheel twee fondsen beschikbaar, met een financieringsbudget van zo'n $f 16$ miljoen (Waterreus, 1997). Voor de ruim 250.000 werkenden in de sector is dat erg weinig.

Opvallend is overigens wel dat het percentage werkenden dat deelneemt aan bedrijfsopleidingen in de sector veebouderij sterk stijgt. Mogelijk heeft de recente uitdunning van de veestapel veel werkenden ertoe aangezet opleidingen te volgen om op een andere manier binnen de sector aan de slag te blijven. In de sector overige industrie zet de dalende trend die in de vorige rapportage werd aangetroffen niet door. Zowel het percentage werkenden dat deelneemt aan bedrijfsopleidingen als het percentage werkenden dat deelneemt aan andere opleidingen stabiliseert op een relatief laag niveau.

Tabel 5.4

Percentage werkenden dat deelneemt aan opleidingen, naar bedrijfssector, gemiddelde 1997-1998

\section{Bedrijfssector}

Landbouw en visserij

Voeding

Chemie

Metaal-en elektrotechniek

Overige industrie

Energie

Bouw en onroerend goed

Handel en reparatie

Transport en communicatie

Bank- en verzekeringswezen

Horeca en zakelijke dienstverlening

Kwartaire diensten

Overheid en onderwijs

\section{Bedrijtsopleidingen \\ $\%$ trend}

fluctuerend
fluctuerend
fluctuerend
stijgend
fluctuerend
dalend
sterk stijgend
sterk stijgend
sterk stijgend
stigend
sterk stijgend
dalend
flucturend

\section{Andere opleidingen \\ $\%$ trend}

3 sterk dalend

6 fluctuerend

7 fluctuerend

6 fluctuerend

$5 \quad$ fluctuerend

8 fluctuerend

6 stijgend

10 sterk stiggend

6 dalend

13 fluctuerend

10 stijgend

7 fluctuerend

7 dalend

Bron: $\mathrm{CBS} / \mathrm{ROA}$

In de sectoren handel en reparatie en transport en communicatie wordt door steeds meer werkenden deelgenomen aan bedrijfsopleidingen. Omdat het percentage echter nog relatief laag is, lijkt er in beide bedrijfssectoren sprake te zijn van een inhaalslag. Voor de sector bandel en reparatie geldt dat in versterkte mate aangezien ook het percentage werkenden dat deelneemt aan andere opleidingen sterk stiigt. Binnen deze sector zijn ook relatief veel opleidings- en ontwikkelingsfondsen voor handen 
In tabel 5.5 wordt een overzicht gegeven van de beroepssegmenten met een relatief laag percentage werkenden dat deelneemt aan bedrijfs- en andere opleidingen ${ }^{36}$. Behalve het feit dat over vrijwel de gehele linie minder wordt deelgenomen aan bedrijfsopleidingen dan aan andere opleidingen, respectievelijk 5 en $8 \%$, is nog een aantal opvallende zaken aan te wijzen.

\section{Tabel 5.5}

Beroepssegmenten met het laagste percentage werkenden dat deelneemt aan bedrijfsopleidingen en andere opleidingen, 1997-1998

Beroepssegment

Bedrijfsopleidingen

Middelbare agrarische beroepen

Hogere taalkundige, culturele beroepen

Wetenschappelijke landbouwkundige beroepen

Lagere niet-specialistische beroepen

Lagere transportberoepen

Lagere agrarische beroepen

Lagere docenten sportvakken

Middelbare taalkundige, culturele beroepen

Elementaire beroepen

Middelbare docenten transport-, sportvakken

\section{Andere opleidingen}

Middelbare agrarische beroepen

Wetenschappelijke landbouwkundige beroepen

Wetenschappelijke pedagogische beroepen

Lagere transportberoepen

Hogere taalkundige, culturele beroepen

Hogere transportberoepen

Lagere niet-specialistische beroepen

Wetenschappelijke technische beroepen

Middelbare wiskundige, natuurw. beroepen

Lagere agrarische beroepen

\section{$\% \quad$ typering trend}

$\begin{array}{ll}\text { laag } & \text { fluctuerend } \\ \text { laag } & \text { fluctuerend } \\ \text { gemiddeld } & - \\ \text { gemiddeld } & - \\ \text { gemiddeld } & \text { fluctuerend } \\ \text { gemiddeld } & \text { dalend } \\ \text { gemiddeld } & - \\ \text { gemiddeld } & \text { fluctuerend } \\ \text { gemiddeld } & \text { constant } \\ \text { gemiddeld } & \text { fluctuerend }\end{array}$

erg laag

erg laag

fluctuerend

erg laag

erg laag

erg laag

erg laag

erg laag

laag

laag

laag dalend

fluctuerend

sterk dalend

sterk dalend

fluctuerend

fluctuerend

sterk dalend

fluctuerend

Bron: CBS/ROA

Het zijn de werkenden in de middelbare agrarische beroepen die het minste aan scholing deelnemen. Zowel voor wat betreft de deelname aan bedriffsopleidingen als de deelname aan andere opleidingen scoort dit beroepssegment het slechtsi. Ook door de werkenden in de lagere agrarische beroepen en de wetenscbappelijke landbouwkundige beroepen wordt echter weinig aan bedrijfsopleiding of andere opleiding deelgenomen. Eerder bleek ook al dat de sector landbouw en visserij wordt gekenmerkt door relatief lage deelnameciffers. Des te opvallender is het dat werkenden in de bogere landboutkundige beroepen juist relatief veel aan opleidingen deelnemen.

36 Zie ook fabellen 5.12 en 5.13 in de Statisrische Bijlage. 
Wanneer wordt gekeken naar de trend van de laatste jaren dan blijkt dat er in een aantal beroepssegmenten sprake is van een daling in het percentage werkenden dat deelneemt aan scholing. Met name de participatie in andere opleidingen dan bedrijfsopleidingen neemt af. Een mogelijke oorzaak is de toename van de werkdruk, waardoor veel werkenden alleen nog maar tijd hebben om de broodnodige bedrijfsopleidingen te volgen. Zij kunnen het zich daardoor niet meer permitteren andere scholing te volgen. Onder andere de werkenden in de bogere taalkundige, culturele beroepen en de bogere transportberoepen nemen de laatste jaren steeds minder deel aan andere dan bedrijfsopleidingen. In deze beroepen is ook sprake van hoge tijdsdruk (zie hoofdstuk 2).

Dat de werkenden in de hogere taalkundige, culturele beroepen niet zoveel aan scholing doen is overigens voor een belangrijk deel te wijten aan het feit dat zich in dit beroepssegment ook de kunstenaars bevinden. Zij houden zich over het algemeen niet bezig met aanvullende bedrijfs- of andere opleidingen.

\section{Opleiding}

In tabel 5.6 wordt een overzicht gegeven van de opleidingsrichtingen die worden gekenmerkt door een lage scholingsdeelname ${ }^{37}$. Uit de tabel komen met name de hogere kunstopleidingen HBO kunst en WO kunst naar voren als 'scholingsarme' opleidingsrichtingen. Aangezien eerder al bleek dat het vooral kunstenaars zijn die weinig aan scholing doen is dat niet vreemd.

Behalve door werkenden met een hogere of academische kunstopleiding wordt ook door werkenden met opleidingen gericht op de landbouw slechts sporadisch aan additionele scholing gedaan. De opleidingsrichtingen WO landbouw en milieukunde, $\checkmark M B O$ landbouw en natuurlike omgeving en MBO landbouw en naturlijke omgeving behoren tot de opleidingsrichtingen waar bedrijfsopleidingen het minst worden gevolgd. VMBO landbouw en naturlijke omgeving en $M B O$ landbouw en natuurlijke omgeving behoren bovendien tot de vijf opleidingsrichtingen waar nauwelijks aan andere opleidingen wordt deelgenomen. Ondat werkenden met een initiële opleiding op middelbaar of hoger niveau een redelijk stevige positie op de arbeidsmarkt hebben, hoeft niet direct te worden gevreesd voor de arbeidsmarktpotentie van werkenden met bijvoorbeeld WO landbouw en milieukunde.

Veel kwetsbaarder is daarentegen de positie van werkenden met 'slechts' basisonderwijs of een opleidingsachtergrond VMBO zorg en welzijn of VMBO landbouw en natuurlijke omgeving. Werkenden met een van deze opleidingsachtergronden nemen weinig deel aan zowel bedrijfsopleidingen als aan andere opleidingen, bovendien is het niveau van hun initiële opleiding laag. Vooral voor de werkenden met een opleiding VMBO landbouw en natuurlijke omgeving, van wie het percentage dat bedriffsopleidingen volgt de laatste jaren sterk daalt, lopen wat betreft scholing en ontwikkeling wat achter op de overige werkenden.

37 Zie ook tabellen 5.19 en 5.20 in de Stalistische Bijlage. 
Tabel 5.6

Opleidingsrichtingen met het laagste percentage werkenden dat deelneemt aan bedrijfsopleidingen en andere opleidingen, 1997-1998

Opleidingsrrichting

Bedrijfsopleidingen

HBO kunst

W0 kandbouw en milieukunde

VMBO landbouw en natuurlijke omgeving

VMBO zorg en welzijn

MBO landbouw en natuurlijke omgeving

Basisonderwijs

Andere opleidingen

Wo kunst

MBO landbouw en natuurlipke omgeving

Basisonderwijs

VMBO zorg en welzijn

VMBO landbouw en natuurlijke omgeving

Wo techniek

Bron: CBS/ROA
$\%$

typering

trend

\subsection{Functionele flexibiliteit}

De aandacht voor de functionele flexibiliteit van werkenden maakt in veel organisaties deel uit van een breder beleidskader dat erop gericht is werkenden te stimuleren en te begeleiden bij het 'employable' houden van hun competenties. Het volgen van scholing neemt hierbij vanzelfsprekend een belangrijke plaats in. Behalve door het volgen van additionele scholing kunnen werkenden zich echter ook wapenen tegen kwalificatieveroudering door zich een zekere mate van functionele flexibiliteit aan te meten. Functioneel flexibel zijn de werkenden die zowel de bereidheid als het vermogen hebben zich met name binnen de organisatie, maar ook daarbuiten, breed in te zetten.

Zowel werkgevers als werknemers kunnen veel profijt hebben van de functionele flexibiliteit van werkenden. Werknemers behoudlen hun waarde voor de arbeidsmarkt, door zich zo breed mogelijk te ontplooien en op verschillende gebieden ervaring op te doen. Wanneer ze het risico lopen hun werk te verliezen zullen zij gemakkelijker elders aan de slag kunnen. Werkgevers kunnen met een flexibel personeelsbestand hun markt beter en sneller bedienen (Glasbergen, 1994). Met name wanneer de externe omgeving moeilijk te beìnvloeden is, doordat bijvoorbeeld sprake is van een grote concurrentie, is het voor organisaties van belang interne flexibiliteit na te streven (Wijgaerts, 1985). Bovendien makt een tlexibel personeelsbestand het voor de organisatie gemakkelijker werkenden die overtollig dreigen te worden te herplaatsen. Het mes van de flexibele inzetbaarheid snijdt dus aan twee kanten.

Om een beeld te kriigen van de mate waarin werkenden in staat zijn om door een functioneel flexibele houding kwalificatieveroudering te voorkomen en bij een eventueel 
verlies van hun baan toch aan de slag te blijven, is gebruik gemaakt van een aantal indicatoren. Deze indicatoren hebben betrekking op een tweetal dimensies namelijk iemands mobiliteit en inzetbaarbeid. Bovendien worden per dimensie twee aspecten onderscheiden: iemands bereidbeid en iemands vermogen. Beide aspecten zijn van vitaal belang. Pas wanneer sprake is van een bereidheid tot een brede inzet en mobiliteit in combinatie met het vermogen tor een brede inzet en mobiliteit, kan worden gesproken van in potentie functioneel flexibel personeel. Er zijn derhalve vier eigenschappen van belang: mobiliteitsbereidheid, mobiliteitsvermogen, bereidheid tot een brede inzet en vermogen tot een brede inzet (zie ook: Singerling en Mes, 1994; Bolweg en Van Beckhoven, 1995 en De Grip, Van Loo en Sanders, 1999). Deze vier indicatoren worden hieronder kort toegelicht.

\section{Mobiliteitsbereidheid en mobiliteitsvermogen}

Mobiliteitsbereidheid kan worden omschreven als de bereidheid van werkenden om van functie c.q. fysieke werklokatie te veranderen of over te stappen naar een andere organisatie. Aangezien mobiliteitsbereidheid getuigt van een flexibele instelling van de kant van de werknemer vergroot het de kansen op werk (Gaspersz en Ott, 1996). Overigens is het niet altijd zo dat een werknemer die aangeeft wel eens te solliciteren naar een andere functie dat doet omdat hij of zij dat graag wil. De verandering van functie kan ook min of meer gedwongen van aard zijn. Een functie kan bijvoorbeeld op het punt staan te verdwijnen, zodat een werkende gedwongen is bereid te zijn van functie te veranderen. Ook kan een werkende zich niet thuis voelen in de huidige functie of werkomgeving, doordat collega's zich allesbehalve vriendelijk opstellen. Ook in dat geval is sprake van min of meer opgelegde mobiliteitsbereidheid. Een écht mobiliteitsbereide houding hebben werkenden pas wanneer zij volledig uit vrije wil solliciteren. In de verdere analyses wordt om deze reden rekening gehouden met de achtergronden van de mobiliteitsbereidheid en worden op basis hiervan gradaties aangebracht.

Naast het feit dat werkenden tot op zekere hoogte bereid zouden moeten zijn om geregeld van functie, werklokatie of organisatie te veranderen, moet men ook de capaciteit hebben om een dergelijke stap te zetten. Werkenden die wel van functie willen veranderen maar dat als gevolg van bijvoorbeeld een gebrek an competenties niet kunnen, lopen een groot risico dat hen bij een eventueel verlies van hun huidige baan geen andere uitweg rest dan het verlaten van de arbeidsmarkt. Overigens is niet alleen het gebrek aan competenties funest, ook een zeer geconcentreerde ervaring en de daarmee samenhangende uiterst specifieke kennisopbouw kunnen ervoor zorgen dat veranderingen in aard van de functie direct tot grote problemen leiden. Werkenden met een zéer specifiek menselijk kapitaal zijn immers slechts zeer beperkt inzetbaar, zowel binnen als buiten de organisatie waarin zij werkzaam zijn. Het mobiliteitsvermogen van werkenden wordt derhalve grotendeels bepaald door de verblijfsduur van werkenden in hun huidige functie bij hun huidige werkgever. Thijssen (1997) bestempelde dit als de ervaringsconcentratie van werkenden. 


\section{Functionele flexibiliteit: Flexpool ABP/USZO}

ABP/USZO kreeg een aantal jaren geleden te maken met aan de ene kant een overschot aan (intern) personeel, terwijl aan de andere kant een groot aantal mensen extern werd aangetrokken via uitzendbureaus, of detacheringsorganisaties. Om dit overschot weg te werken heeft men indertijd besloten om een "Flexpool" op te zetten. Het beoogde doel van deze flexpool is tweeledig: aan de ene kant worden tijdelijke tekorten op bepaalde plekken binnen ABP/USZO opgevuld, aan de andere kant krijgen werknemers de kans om intern te rouleren tussen banen c.q. functies. Bovendien is deze mobiliteit ook gezond voor het bedrijf, zeker omdat er buiten de flexpool tot nu toe zeer weinig gebeurt op dit terrein.

De flexpool heeft 70 vaste medewerkers in dienst, daarnaast werken er via de flexpool circa 300 mensen op uitzend- of detacheringsbasis en nog eens circa 300 "IT" ers" op projectbasis. Het werk- en opleidingsniveau van de vaste medewerkers varieert van middelbaar opgeleiden, voor administratieve werkzaamheden tot hoger opgeleiden, voor het vervullen van management- en specialistenfuncties. Externen die via de flexpool worden gedetacheerd zijn meestal middelbaar opgeleiden. Doordat deze werknemers in vaste dienst zijn van de flexpool, worden er automatisch regelmatig functioneringsgesprekken gevoerd. Samen met de werknemer wordt tijdens die gesprekken een loopbaan uitgestippeld, het toekomstperspectief bekeken en opleidingsmogelijkheden geboden.

Alle wervingsactiviteiten van tijdelijk personeel voor ABP/USZO dienen via de flexpool te lopen. De duur van de periode waarvoor een flexpoolmedewerker bij een bepaalde afdeling wordt ingezet is zeer verschillend. Er zijn werknemers die twee à drie jaar bij een afdeling zitten, waarna ze vaak ook "vast" bij die afdeling gaan werken wanneer er een vacature is. De gemiddelde periode warvoor een flexpoolmedewerker bij een afdeling wordt ingezet bedraagt circa een jaar, met als minimum een half jaar. De mogelijkheid om bij een afdeling "vast" in dienst te komen zorgt ervoor dat er een redelijke doorstroom binnen de flexpool wordt bereikt. Circa 20\% van de flexpoolmedewerkers stroomt jaarlijks op deze manier uit de flexpool.

De flexpool haalt een bezettingsgraad van bijna 100\%. Slechts $0,5 \%$ van de medewerkers waarvan het contract afloopt kan niet direct aan de slag op een andere plek. De flexpool biedt werknemers niet alleen mobiliteitsmogelijkheden, maar ook de mogelijkheid om opleidingen te gaan volgen. Circa $1 \%$ van de personeelskosten van de flexpool wordt aan opleiding en training van de medewerkers besteed. Dit is exclusief de werktijd die wordt besteed aan volgen van scholing. Daarnaast kunnen medewerkers ook vaak op de afdeling waarop ze op dat moment werkzaam zijn cursussen en trainingen volgen. Deelname aan de flexpool gebeurt geheel op vrijwillige basis. Werknemers die afwisseling in hun takenpakket prefereren kunnen dit door participatie in de flexpool verkrijgen en daarmee tegelijkertijd hun perspectieven binnen ABP/USZO vergroten. Ook kan het gebeuren dat medewerkers zich op initiatief van hun leidinggevende aanmelden bij de flexpool. Hierbij is overigens nooit sprake van een vorm van dwang. 
Uitzendkrachten en werknemers op detacheringsbasis kunnen maximaal twee jaar via de flexpool aan de slag. Na deze periode van twee jaar dienen zij óf in vaste dienst van ABP/USZO te worden genomen, óf een andere werkgever te zoeken. Het cerste komt maar zelden voor. Bij een inkrimping van de flexpool moeten de externen (uitzendkrachten en werknemers op detacheringsbasis) de flexpool als eerste verlaten. De 70 vaste medewerkers van de flexpool hebben bovendien de prioriteit bij het invullen van interne vacatures.

Bron: Interview met Dbr. M. Brans, manager Flexpool, verbonden aan ABP/USZO.

\section{Bereidheid en vermogen tot brede inzet}

Behalve dat werkenden bereid en in staat zouden moeten zijn om van functie, werklokatie of organisatie te veranderen is het ook van belang dat zij zich in hun huidige functie flexibel opstellen en breed inzetbaar zijn. Deze brede inzetbaarheid heeft betrekking op de bereidheid en het vermogen van werkenden om zo nu en dan werkzaamheden te verrichten die buiten het eigen functiegebied liggen. Zijn werkenden bereid en in staat zich ook buiten het eigen functiegebied nuttig te maken voor de organisatie, dan vergroot dat enerzijds de slagvaardigheid van de organisatie, terwijl anderzijds de werkenden zich op deze wijze wapenen tegen het risico van ervaringsconcentratie. Bovendien leren zij door zich breed in te zetten meerdere facetten van de organisatie kennen en ontdekken zij misschien zelfs nieuwe interesses c.q. competenties in zichzelf. Door zich breed in te zetten leren werkenden dus niet alleen de organisatie beter kennen, maar ook zichzelf.

Aan de hand van bovengenoemde indicatoren wordt in cleze paragraf inzicht verschaft in de functionele flexibiliteit van werkenden. Wederom zal bij het onderscheiden van de belangrijkste risicogroepen worden verbijzonderd naar bedrijfsgrootte, bedrijfssector, beroep en opleidingstype.

\section{Bedrijfsgrootte}

Tabel 5.6 laat zien dat het met name de grote bedrijven ${ }^{38}$ zijn die qua functionele flexibiliteit van hun personeel wat achter blijven bij de kleinere bedrijven ${ }^{39}$. Wanneer getseken wordt naar de bereidheid van werkenden om zich breed in te zetten, blijkt dat met name de werkenden in middelgrote en grote bedrijven, indien nodig, bereid zijn om zich in te zetten voor werkzaamheden uit een andere functie of op een andere afdeling, respectievelijk $74 \%$ en $73 \%$. Zij blijken dit echter minder vaak ook daadwerkelijk te doen. Het vermogen van werkenden om breed te worden ingezet is bij werkenden in de grotere bedrijven duidelijk minder groot dan bij de werkenden in het midden- en kleinbedrijf. Van de werkenden die zich bereid verklaren zich breed in te zetten, heeft binnen de grote bedrijven slechts $20 \%$ dit vaak gedaan. Binnen de middelgrote bedrijven was dat $25 \%$ en in de kleine bedrijven zelfs $29 \%$. Een verklaring hiervoor kan zijn

38 Het gaat hierbij on de vestiging wat werkenden werkaam zijn, dus niet om de lobak omvang van het bedrijf waarvoor men werkt.

39 Zie ook tabel 5.3 in de Statistiscbe Bijlage. 
dat binnen grote bedrijven vaak meerdere werkenden werkzaam zijn in dezelfde functie of op dezelfde afdeling. Zij nemen in geval van ziekte of cursus vaak werkzaamheden over van collega's. Zij nemen dan wel werkzaamheden over, maar niet zodanig dat dit hun functionele flexibiliteit vergroot.

\section{Flexibiliteit en brede inzetbaarheid bij Stork Mobiel}

Stork is met 55 werkmaatschappijen opgebouwd uit 90 vestigingen en zo'n 13.500 werknemers binnen Nederland een van de grootste ondernemingen op het gebied van investeringsgoederen, industriële dienstverlening en engineering. De laatste jaren besteedt Stork veel aandacht aan het verbeteren van de mobiliteit, flexibiliteit en opleiding van personeel. Met het in het leven roepen van de Stuurgroep Mobiel 2000 werd in 1997 een begin gemaakt met het concernbreed organiseren van her thema flexibiliteit. Wat het meest opvalt aan deze stuurgroep is dat ze bestaat uit vertegenwoordigers van zowel de directie van Stork, de Centrale Ondernemingsraad als de vakverenigingen en Start Uitzendorganisatie. De stuurgroep werd bovendien geassisteerd door een extern organisatieadviesbureau. De stuurgroep heeft ervoor gekozen binnen het Stork concern een aparte werkmaatschappij op te richten om invulling te geven aan het flexibiliseren van de (interne) arbeidsmarkt: Stork Mobiel BV.

Stork Mobiel heeft drie hoofdtaken: bemiddelen (waaronder collegiaal in- en uitlenen), detacheren en opleiden. Hoewel Stork Mobiel naar winst streeft is maximalisatie ervan geen primaire doelstelling. De winst die Stork Mobiel maakt wordt besteed aan de verdere scholing van het personeel dat werkzaam is bij Stork Mobiel. Stork Mobiel moet opdrachten zien te verwerven van de Stork werkmaatschappijen. Daarbij is er geen sprake van gedwongen winkelnering. Dit maakt dat Stork Mobiel gebaat is bij het leveren van kwalitatief hoogstaande arbeid. Werknemers die zich aanmelden bij Stork Mobiel moeten derhalve voldoen aan een aantal vrij strenge criteria. Stork Mobiel mag in geen geval gezien worden als een 'kneuzenbak'. Bovendien is het zo dat werknemers zich vrijwillig aanmelden bij Stork Mobiel.

Een aantal categorieën werknemers meldt zich bij Stork Mobiel:

- Jonge hoger opgeleiden die al een paar jaar bij Stork werken. Zij willen zich breed ontwikkelen en dus niet binnen een en dezelfde werkmaatschappij blijven werken;

- Wat 'oudere' werkenden in de leeftijd van 40-50 jaar, die op hun vakgebied aan het plafond van hun ontwikkeling zijn gekomen en duidelijk aangeven dat zij zich in de resterende jaren van hun loopbaan nog graag met wat andere dingen binnen Stork zouden willen bezighouden;

- Mensen die niet lekker in hun vel zitten op hun huidige werkplek, maar op zich kwaliteiten genoeg hebben om goed te functioneren;

- Mensen die relatief slecht presteren. Deze groep voldoet slechts zelden aan de strenge intake-criteria van Stork Mobiel;

- Hoger opgeleide mensen die al enige tijd via een uitzendbureau of detacheringsbureau bij Stork werken en zich daar prima thuis voelen.

Stork Mobiel neemt pas werknemers in dienst als een eerste plaatsing bij een werkmaatschappij een feit is. Over het algemeen werkt men zo'n 6 tot 8 maanden in een 
bepaalde functie. Daarna wordt meestal een nieuwe plaatsing geregeld bij dezelfde of een andere werkmaatschappij. Indien blijkt dat plaatsing binnen Stork niet meer mogelijk is wordt de 'derde markt' opgezocht. Op dit punt zijn er duidelijke afspraken gemaakt met een aantal uitzendorganisaties, zoals Randstad, Vedior en Start.

Om inzicht te krijgen in de ontwikkeling en de capaciteiten van werknemers van Stork Mobiel wordt een persoonlijk opleidingsplan (POP) opgesteld. Dit gebeurt pas als een werknemer al een tijdje aan de slag is en duidelijk is wat de scholingsbehoefte precies inhoudt. Wanneer het POP eenmaal is opgesteld, dan wordt een werknemer eventueel ingeschreven bij een opleiding. Deze opleiding kan zowel intern als extern worden ingekocht. Ultimo 1999 telt Stork Mobiel al 150 werknemers en gaat men hard op weg naar de 200. Tot voor kort was Stork Mobiel nog niet optimaal geoutilleerd om voor zo'n snel toenemend aantal werknemers POP's in combinatie met loopbaanbegeleiding te arrangeren. Omdat dit juist het onderscheidend argument is van Stork Mobiel is inmiddels een aparte gespecialiseerde medewerker in dienst genomen, die dit traject verder ontwikkelt.

Stork Mobiel Opleidingen biedt bovendien een drietal mobiliteitsopleidingen aan Mens en Mobiliteit, Mens en Loopbaan en Leiding en Mobiliteit. De eerste opleiding geeft mensen een beter inzicht in de consequenties van mobiliteit en de kansen die mobiliteit hen biedt. De opleiding Mens en Loopbaan helpt mensen bij het verkrijgen van een beter inzicht in wat zij willen en kunnen en hoe zij bepaalde wensen kunnen uiten of hun capaciteiten kunnen uitbreiden. De opleiding Leiding en Mobiliteit biedt aan leidinggevenden een verheldering van de mobiliteitsproblematiek. In deze training wordt onder andere duidelijk gemaakt dat het tijdelijk uitlenen van de betere werknemers uit een team, waarin tijdelijk overbezetting is ontstaan, erg zinvol kan zijn. De mobiliteitstrainingen worden grotendeels 'in-company' gegeven.

Een gemiste kans is vooralsnog dat alleen de bedrijven met problemen zich melden, terwijl juist preventieve scholing grote voordelen zou bieden. Wanneer zou blijken dat over enkele jaren de deelname aan opleidingen nog steeds enkel een curatief karakter heeft, is dat volgens de manager opleidingen op zich "voldoende reden om de gehele opleidingsactie een 'niet geslaagde actie' te noemen".

Bij technische mensen wordt overigens een toenemende behoefte aan niet-technische opleidingen, zoals sociale en commerciële vaardigheidstrainingen gesignaleerd. Hierbij moet de kanttekening worden geplaatst dat de behoefte aan dergelijke trainingen meestal niet bij werknemers zelf ontstaat maar vooral vanuit leidinggevenden wordt geinitieerd.

De belangrijkste knelpunten waarmee Stork Mobiel wordt geconfronteerd liggen op het gebied van de communicatie. Stork Mobiel wordt buiten Stork nog steeds gezien als een uitzendbureau of een staforganisatie. Als Stork Mobiel al ergens mee te vergelijken is dan is het echter met een detacheringsbedrij. Stork Mobiel werkt met mensen "van Stork voor Stork", dát is het uitgangspunt.

Bron: Mierview met Dhr. Drs. J. Van Enp, manager opleidingen bij Stork Mobiel. 
Qua mobiliteitsbereidheid springt de sector landbouw en visserij er in positieve zin uit. 33 Procent van de werkenden in deze sector zoekt op eigen initiatief een andere baan. Mogelijk houdt dit hoge percentage verband met de slechte perspectieven in de veeteelt, als gevolg van de recente uitdunning van de veestapel. De werkenden in de sectoren energie, transport en communicatie en overbeid en onderwijs zijn het minst mobiliteitsbereid. Slechts $6-8 \%$ van de werkenden in deze sectoren zoekt op eigen initiatief of heeft op eigen initiatief gezocht naar een andere baan.

\section{Tabel 5.7}

\section{Functionele flexibiliteit naar bedrijfssector ${ }^{*}$, index 1998}

\begin{tabular}{|c|c|c|c|c|c|}
\hline Bedrijfssector & $\begin{array}{l}\text { IB } \\
\%\end{array}$ & $\begin{array}{l}\text { IV } \\
\%\end{array}$ & $\begin{array}{c}\mathrm{MB} \\
\%\end{array}$ & $\begin{array}{l}\text { MV } \\
\text { typering }\end{array}$ & $\begin{array}{l}\text { Functionele } \\
\text { flexibiliteit }\end{array}$ \\
\hline Landbouw en visseri! & 83 & 33 & 22 & erg hoog & 146 \\
\hline Voeding & 81 & 27 & 9 & hoog & 105 \\
\hline Chemie & 72 & 31 & 11 & hoog & 109 \\
\hline Metaal en elektrotechniek & 75 & 25 & 10 & gemiddeld & 99 \\
\hline Overige industrie & 85 & 20 & 13 & gemiddeld & 105 \\
\hline Energie & 77 & 29 & 6 & laag & 91 \\
\hline Bouw en onroerend goed & 76 & 21 & 10 & hoog & 99 \\
\hline Handel en reparatie & 75 & 28 & 16 & gemiddeld & 113 \\
\hline Transport en communicatie & 69 & 21 & 8 & gemiddelid & 88 \\
\hline Bank-en verzekeringswezen & 76 & 23 & 10 & erg hoog & 102 \\
\hline Horeca en zakelijke dienstverlening & 74 & 22 & 18 & hoog & 116 \\
\hline Kwartaire diensten & 64 & 20 & 11 & laag & 87 \\
\hline Overheid en onderwijs & 74 & 23 & 8 & laag & 88 \\
\hline
\end{tabular}

* zie noot bij tabel 5.6

Bron: OSNROA

Het risico van ervaringsconcentratie is het grootst voor de werkenden in de sectoren energie, kwartaire diensten en overbeid en onderwijs. In deze sectoren is immers het mobiliteitsvermogen het laagst, wat erop duidt dat de werkenden in deze sectoren gemiddeld het langst op hun huidige plek zitten. Opvallend is dat de werkenden in de sectoren energie en overbeid en onderwijs zowel qua mobiliteitshereidheid als qua mobiliteitsvermogen relatief slecht scoren. Ondanks dat zij al relatief lang op één plek zitten, zijn zij ook het minst van plan die plek op eigen initiatief te vertaten. De hoge ervaringsconcentratie van de werkenden in de sector overheid en onderwijs kan deek verklaard worden door het feit dat leraren en onderwijzers niet gauw geneigd zijn te vertrekken van de school waar zij lesgeven. Het salaris dat zij elders kunnen verdienen zal immers hetzelfde zijn. Vanwege de formele procedures bij een eventuele inkrimping van de werkgelegenheid hebhen scholen er bovendien geen belang bij om docenten met een langere werkervaring op een andere school aan te trekken. Voor grote groepen gemeente-ambtenaren geldt eveneens dat zij voor het werk dat zij doen in elke gemeente ongeveer hetzelfde salaris verdienen. Dit is een belangrijk verschil met het bedrijfsleven war een overstap naar een ander bedrijf vaak wel de moeite waard is. In de sectoren bank- en verzekeringswezen en boreca en zakelijke dienstvertening bijvoorbeeld is het risico op ervaringsconcentratie een stuk geringer, omdat een verandering van functie of werkgever in die sectoren vaak aantrekkelijk is. 


\section{Beroep}

In tabel 5.8 wordt een overzicht gegeven van de functionele flexibiliteit van werkenden. verbijzonderd naar beroepssector ${ }^{41}$. Werkenden in de pedagogiscbe beroepen blijken het minst flexibel. Het gaat hierbij met name om leraren en docenten, die, zoals gezegd, minder snel geneigd zijn van baan te veranderen, omdat hen dat niet veel extra's zal opleveren. De salarissen voor onderwijzend personeel liggen immers vast.

Ook werkenden in medische en paramediscbe beroepen en culturele beroepen blijken tot de minst functioneel flexibele groepen werkenden te behoren. Bij de eerste groep wekt dat geen verbazing. Werkenden in de medische en paramedische beroepen hebben veel met hoge werkdruk te maken. Bekend is bijvoorbeeld de hoge werkdruk in ziekenhuizen. Deze hoge werkdruk zorgt ervoor dat werkenden minder snel bereid en in staat zullen zijn om werkzaamheden van collega's over te nemen. Bovendien behoren huisartsen, apothekers en therapeuten tot deze categorie werkenden. Dit zijn professionals die vrij specifiek werk verrichten. Dit werk kan niet zomaar door anderen worden overgenomen, net zomin als dat deze professionals het werk van anderen zomaar zouden kunnen overnemen.

Uit de cijfers die betrekking hebben op de bereidheid van werkenden om zich breed in te zetten blijkt ook dat met name de werkenden in de medische en paramedische beroepen niet vaak bereid zijn zich indien nodig breed in te zetten. Slechts $57 \%$ geeft aan dit wel te willen doen. Ook in de transportberoepen en de verzorgende en dienstverlenende beroepen is de animo om breed te worden ingezet gering. Dit is waarschijnlijk een direct gevolg van het feit dat de beide beroepssectoren veel relatief sterk afgebakende beroepen omvatten, zoals slager, bakker en bijvoorbeeld chauffeur. In deze beroepen is een brede inzet vaak niet mogelijk. Bovendien voelen bijvoorbeeld winkeliers, caféhouders en bakkers zich verantwoordelijk voor het gehele reilen en zeilen binnen hun winkel, café of bakkerij, waardoor zij sowieso nagenoeg alle werkzaamheden die zich binnen het bedriff voordoen tot hun eigen functie rekenen.

Het vermogen om zich breed in te zetten is het grootst bij werkenden in de agrarische beroepen. Ruim 30\% van de werkenden in deze beroepssector geeft aan valk werkzaamheden te verrichten die niet tot hun eigen functie of afdeling behoren. Daarentegen verrichten de werkenden in culturele beroepen niet valk werkzamheden die niet tot de eigen functie of afdeling behoren. Hetzelfde getd voor de werkenden in de sociaal-culhrele beroepen en de informaticaberoepen. Mogelijk heeft dit laatste te maken met de hoge werkdruk, die veel werkenden binnen deze beroepssectoren parten speelt (zie ook hoofdstuk 2). Met name werkenden in de informaticaberoepen (informatici) hebben hiermee te maken, maar ook binnen de sociaal-culturete beroepen (sociaal werenschappelijk onderzoekers) en de culmele beroepen (journalisten, taalkundigen) is de tijdsdruk relatief hoog. Door de hoge tijdsdruk is het vaak niet mogelijk werkzaamheden van anderen over te nemen. Daarnaast speelt warschijnlijk ook specialisatie een belangrijke rol.

41 Zie ook tabellen 5.15 tot en med 5.18 in de Statistische Bijlage. 
Tabel 5.8

Functionele flexibiliteit naar beroepssector*, index 1998

Beroepssector

Pedagogische beroepen

Medische en paramedische beroepen

Culturele beroepen

Openbare orde- en veiligheidsberoepen

Technische en industrieberoepen

Verzorgende en dienstv. beroepen

Transportberoepen

Agrarische beroepen

Economisch-administratieve beroepen

Sociaal-culturele beroepen

Informaticaberoepen

* zie noot bij tabel 5.6

Bron: OSAROA

$\begin{array}{ccclr}\text { IB } & \text { IV } & \text { MB } & \text { MV } & \text { Functionele } \\ \% & \% & \% & \text { typering } & \text { flexibiliteit }\end{array}$

$\begin{array}{rrrll}70 & 29 & 6 & \text { erg laag } & 80 \\ 57 & 22 & 10 & \text { laag } & 85 \\ 78 & 11 & 13 & \text { gemiddeld } & 93 \\ 78 & 21 & 8 & \text { hoog } & 98 \\ 78 & 22 & 10 & \text { gemiddeld } & 98 \\ 65 & 25 & 13 & \text { laag } & 98 \\ 64 & 24 & 13 & \text { gemiddeld } & 99 \\ 75 & 32 & 11 & \text { laag } & 106 \\ 80 & 24 & 13 & \text { hoog } & 110 \\ 71 & 18 & 18 & \text { hoog } & 112 \\ 81 & 19 & 20 & \text { erg hoog } & 128\end{array}$

De mobiliteitsbereidheid blijkt met name in de pedagogische beroepen en de openbare orde en veiligbeidsberoepen achter te blijven met respectievelijk slechts 6 en $8 \%$ van de werkenden die op eigen initiatief zoeken of hebben gezocht naar een andere baan. Zoals al eerder opgemerkt zijn de werkenden in de pedagogische beroepen van oudsher al vrij honkvast.

Ook voor politieagenten, brandweerlieden en bijvoorbeeld soldaten, die behoren tot de categorie openbare orde en veiligheidsberoepen, is een eventuele verandering van baan wat minder voor de hand liggend. Behoort men immers tot een bepaald korps of legeronderdeel dan wordt juist getracht zo min mogelijk verschuivingen teweeg te brengen ondat men in een team functioneert dat zelfs in zeer moeilijke, levensbedreigende situaties op elkaar moet kunnen vertrouwen.

Het op eigen initiatief zoeken naar een andere baan is diarentegen meer gebruikelijk in informaticaberoepen, waar maar liefst $20 \%$ van de werkenden op eigen initiatief naar een andere baan zoekt of recentelijk heeft gezocht. Hetzelfde geldt voor de soctaat-catturele beroepen, waar $18 \%$ naar ander werk zoekt of heeft gezocht.

Het risico van ervaringsconcentratie is het grootst voor werkenden in de pedagogische beroepen. De gemiddelde verbliffsduur in de huidige functie is in deze beroepssector het langst, waardoor het mobiliteitsvermogen het laagst uitvalt. De keraren zijn dens inderdaad honkvast, wat het risico dat zij lopen om vast te roesten vergroot. Naast de werkenden in de pedagogische beroepen blijven ook de werkenden in de agrarische beroepen, de medische en paramedische beroepen en de verzorgende en dienstvetlenende beroepen qua mobiliteitsvermogen achter bij de andere beroepsgroepen. Voor de werkenden in de medische en paramedische beroepen is het lage mobiliteitsvermogen mogelijk niet écht een groot probleem, aangezien in deze beroepssector veel specialisten aan het werk zijn, die weliswar lang werkzaam zijn in hun specialisatie, maar zich daar juist in verder willen ontwikkelen. Aangezien er ook een blijvende vraag is naar dergelijke specialisten loopt hun positie geen gevaar. In de agrarische beroegen heeft 
het geringe mobiliteitsvermogen van de werkenden een geheel andere oorzaak. Veel land- en tuinbouwers of veetelers hebben al hun hele leven gewerkt in hun eigen boerenbedrijf, waardoor het mobiliteitsvermogen laag is.

\section{Opleiding}

In tabel 5.9 wordt een overzicht gegeven van de functionele flexibiliteit verbijzonderd naar opleidingstype ${ }^{42}$. Uit de tabel blijkt dat de functionele flexibiliteit met name gering is bij de lager opgeleiden. Dit geldt het sterkst voor werkenden met een opleiding $\checkmark M B O$ zorg en welzijn. Ook werkenden met 'slechts' basisonderwijs of een opleiding $V M B O$ techniek hebben echter een weinig flexibele instelling. Voorts valt de geringe functionele flexibiliteit van de technisch opgeleiden op. Zowel werkenden met een opleiding VMBO techniek, als werkenden met een opleiding HBO techniek of WO techniek behoren tot de functioneel minst flexibele groepen werkenden. De werkenden met een opleiding VMBO zorg en welzijn scoren met name laag waar het gaat om de bereidheid zich breed in te zetten. Slechts iets meer dan de helft van de werkenden met deze opleidingsachtergrond is bereid ingezet te worden voor werkzaamheden die tot een andere functie of afdeling behoren. Dat is ruim 20\%-punt minder dan gemiddeld. Bovendien zetten slechts weinigen van de werkenden met een opleiding VMBO zorg en welzim zich vaak in voor andere werkzaamheden. De werkenden met een opleiding WO sociaal cultureel overig scoren wat betreft hun inzetbereidheid het op een na slechtst. 65 Procent geeft aan wel eens werkzaamheden van anderen over te willen nemen, terwijl 18\% dit ook daadwerkelijk vaak doet.

De werkenden met een opleiding WO letteren en theologie zijn in de praktijk het minst vaak bezig met werkzaamheden die tot een andere functie of afdeling behoren. Slechts $7 \%$ doet dit vaak. Tot deze groep werkenden behoren veel leraren en geestelijken, die zich niet vaak breed in kúnnen zetten, omdat werkenden om hen heen vaak dezelfde

Tabel 5.9

Functionele flexibiliteit naar opleidingstype* , index 1998 (gemiddelde $=100$ )

\section{Opleidingstype}

VMBO zorg en welzijn

Basisonderwijs

VMBO Techniek

wo letteren en theologie

VMBO Theorie

VMBO Landbouw en nat. omgeving

HBO Techniek

Wo Sociant-cultureel overig

Wo Techniek

HBO Onderwijs en tolk en vertaler

HBO Economic

$\begin{array}{ll}\text { IB } & \text { IV } \\ \% & \% \\ 53 & 1 \\ 71 & 18 \\ 76 & 2 \\ 68 & \\ 76 & 26 \\ 78 & 29 \\ 73 & 12 \\ 65 & 18 \\ 71 & 15 \\ 69 & 27 \\ 78 & 19\end{array}$

IV
$\%$
13
18
24
7
26
29
12
18
15
27
19

$M$
$\%$
7
10
7
16
8
1
12
1
8
12

tzie noot bij tabel 5.6

Bron: OSNROA

MV
typering
gemiddeld
laag
gemiddeld
gemiddeld
laag
laag
gemiddeld
hoog
laag
laas
hoog

\section{Functionele flexibiliteit}

79

91

91

93

94

95

95

96

97

97

97

42 Zie ook tabellen 5.22 tou en met 5.25 in de Statistische Biglage. 
functie bekleden en hun specialisatie hen ook weerhoudt van het verrichten van andere werkzaamheden.

Wanneer de mobiliteitsbereidheid afzonderlijk wordt bekeken blijkt dat vooral werkenden met een lagere opleiding achterblijven. Werkenden met VMBO zorg en welzim, $V M B O$ techniek of VMBO landbouw en naturlijke omgeving scoren het laagst. Slechts $7 \%$ van de werkenden met een dergelijke opleidingsachtergrond geeft aan op eigen initiatief te zoeken, of recentelijk te hebben gezocht naar een andere baan. Ook bij de werkenden met een opleiding VMBO theorie of HBO onderwijs en tolk en vertaler zijn er relatief weinig die op eigen initiatief naar ander werk zoeken.

Qua mobiliteitsvermogen springt met name de opleiding HBO paramedisch eruit. Onder werkenden met deze opleidingsachtergrond is het risico van ervaringsconcentratie het grootst. Ook bij de analyse van het mobiliteitsvermogen naar beroepssector bleek al dat werkenden in de medische en paramedische beroepen relatief laag scoorden.

\subsection{Conclusies}

In dit hoofdstuk zijn de twee belangrijkste wegen om het risico op verlies van werk als gevolg van kwalificatieveroudering te beperken, namelijk scholing en functionele llexibiliteit, in kaart gebracht. Het belangrijkste verschil tussen beide aspecten is dat scholingsdeelname een actieve bezigheid is om kwalificatieveroudering te voorkomen danwel te genezen, terwijl functionele flexibiliteit meer betrekking heeft op de houding van werkenden om zich flexibel op te stellen en op die manier actief te blijven op de arbeidsmarkt. Mochten werkenden als gevolg van belastende arbeidsomstandigheden $\mathrm{en} /$ of technologische, organisatorische of arbeidsmarktontwikkelingen te maken krijgen met een vorm van kwalificatieveroudering en daardoor het risico lopen op verlies van werk, dan kan scholing en functionele flexibiliteit ervoor zorgen dat zij toch in staat zijn aan de slag te blijven. Scholing en een functioneel flexibele opstelling maakt werkenden bovendien aantrekkelijk voor werkgevers die ernaar streven slagvaardig op de markt te opereren.

In tabel 5.10 wordt een samenvattend overzicht gegeven van de segmenten van de arbeidsmarkt die worden gekenmerkt door een geringe deelname aan bedrijfs- en andere opleidingen. Bovendien worden de segmenten die worden gekenmerk door een geringe functionele flexibiliteit van de werkenden in kaart gebracht. Belangrijkste risicogroepen zijn vanzelfsprekend de groepen werkenden, die zowel een lage scholingsdeelname, als een geringe functionele flexibiliteit hebben.

Bij de bedrijfssectoren komen de werkenden binnen de sector transport en communicatie als belangrijkste risicogroep naar voren. Zowel wat betreft de scholingsdeelname als wat betreft functionele flexibiliteit van de werkenden scoort deze sector beneden het gemiddelde. Ook in de vorige rapportage kwam de sector transport en communicalie op dit punt al naar voren als een van de risicosegmenten. 
Tabel 5.10

Belangrijkste segmenten die worden gekenmerkt door lage scholingsdeelname, en/of een geringe functionele flexibiliteit

\section{Risicodimensie}

Lage deelname aan bedrijfs- en andere opleidingen

Bedrijfsgrootte
Bedriffssectoren

Beroepen

Opleidingen

Geringe functionele flexibiliteit

Bedriffsgrootte

Bedripfssectoren

Beroep

Opleidingen
Risicogroep

Kleine bedrijven

Landbouw en visserij

Overige industrie

Transport en communicatie

Middelbare agrarische beroepen

Wetenschappelijke landbouwkundige beroepen Hogere taalkundige, culturele beroepen

Lagere transportberoepen

MBO landbouw en natuurlijke omgeving VMBO zorg en welzijn

VMBO landbouw en natuurlijke omgeving Basisonderwijs

Grote bedrijiven

Overheid en onderwijs

Kwartaire diensten

Transport en communicatie

Middelbare agrarische beroepen

Lagere verzorgende beroepen

Lagere (para)medische beroepen

Hogere pedagogische beroepen

MBO zorg en welzijn

Basisonderwijs

VMBO techniek

wo letteren en theologis

Wordt gekeken naar beroep, dan blijkt dat de werkenden in de middelbare agrarische beroepen zowel qua scholingsdeelname als qua functionele flexibiliteit achterblijen. De agrarisc be beroepen, wattoe de middelbare agrariscbe beroepen behoren werden overigens ook in de vorige rapportage als risicogroep onderscheiden. Wat betreft opleidingsachtergrond zijn het ten slotte de werkenden met een opleiding VMBO zorg en welzijn of bastsonderwijs die zowel qua scholingsdeelname als qua functionele flexibiliteit beneden het gemiddelde scoren, net als in de vorige rapportage overigens.

Het is nu echter de vratag of en in hoeverre weinig scholing en functionele flexibiliteit in de hier onderscheiden risicogroepen ook daadwerkelijk té weinig scholing en functionele flexibiliteit betekent gezien de risico's die men loopt op kwalificatieveroudering. Hierop wordt in het volgende hoofdstuk ingegaan. 


\section{Risicoprofielen en doelgroepen}

\subsection{Inleiding}

In de hoofdstukken twee, drie en vier zijn de belangrijkste risicofactoren met het oog op kwalificatieveroudering beschreven. Hierbij kwamen achtereenvolgens belastende arbeidsomstandigheden, snelle technologische en organisatorische ontwikkelingen en ontwikkelingen op de arbeidsmarkt aan de orde. Aan het einde van elk van deze hoofdstukken is een overzicht gegeven van de groepen werkenden die het meest worden geconfronteerd met deze risicofactoren. In het vorige hoofdstuk werd een overzicht gegeven van de belangrijkste manieren waarop werkenden zich kunnen wapenen tegen deze risico's op en de gevolgen van kwalificatieveroudering: scholing en functionele flexibiliteit.

In dit hoofdstuk zal getracht worden een beeld te geven van de groepen werkenden voor wie de combinatie van risicofactoren het minst gunstig uitpakt. Dit zal net als in de vorige rapportage in eerste instantie gebeuren aan de hand van zogenaamde risicoprofielen. Bovendien wordt gekeken in hoeverre groepen werkenden door middel van scholing en functionele flexibiliteit in staat zijn het verlies van werk als gevolg van kwalificatieveroudering te voorkomen.

In paragraaf 6.2 worden risicoprofielen gepresenteerd naar bedrijfssector, beroepssegment en opleidingstype. Hierbij wordt gekeken naar de fysieke en psychische belasting in de werksituatie, de invloed van technologische en organisatorische ontwikkelingen en de mate van werkgelegenheidskrimp. Bovendien wordt in het risicoprofiel een beeld gegeven van de functionele flexibiliteit en de mate waarin aan scholing wordt deelgenomen. In paragraf 6.3 wordt meer expliciet ingegaan op de te onderscheiden doelgroepen voor het scholingsbeleid. Hierbij worden de verschillende risicofactoren telkens afgezet tegen de scholingsinspanningen en functionele flexibiliteit van de desbetreffende groep werkenden. Hierdoor kunnen de bedrijfssectoren, beroepssegmenten en opleidingstypen in kaart worden gebracht, die te maken hebben met een tekortschietende scholing en/of functionele flexibiliteit gezien de risico's op kwalificatieveroudering. Wordt een bedrijfssector bijvoorbeeld geconfronteerd met relatief veel technologische en organisatorische ontwikkelingen, terwijl er slechts sprake is van een verhoudingsgewijs geringe scholingsinspanning, dan behoren de werkenden in deze bedrijfssector tot de potentiële doelgroepen voor het scholingsbeleid. Ten slote wordt in paragraaf 6.4 een samenvattend overzicht gegeven van de bedrijfssectoren, beroepssegmenten en opleidingstypen met cen relatief grote behoefte aan extra scholing en/of functionele flexibiliteit.

\subsection{Risicoprofielen}

In deze paragraaf worden de risico's op verlies van werk weergegeven met behulp van risicoprofielen. In deze profielen worden de risicofactoren, zoals die in de voorgaande hoofdstukken aan de orde zijn geweest naast elkaar gezet om in één oogopslag de risico-positie van verschillende segmenten op de arbeidsmarkt te kunnen zien. 
Hierbij wordt gekeken naar:

- fysieke belasting

- psychische belasting

- technologische en organisatorische ontwikkelingen

- werkgelegenheidskrimp

- scholingsparticipatie

- functionele flexibiliteit

Voor elk aspect van dit risicoprofiel is een kwalitatieve typering gegeven van de ernst van het risico op kwalificatieveroudering. Hierbij wordt een onderscheid gemaakt tussen de kwalificaties 'laag' (tussen het middelpunt van de figuur en de binnenste zeshoek), 'gemiddeld' (tussen de beide zeshoeken) en 'hoog' (buiten de buitenste zeshoek). Alle risicofactoren zijn rechtstreeks gebaseerd op één van de indicatoren die in de vorige hoofdstukken de revue zijn gepasseerd. Bovendien is ervoor gezorgd dat alle indicatoren zo zijn gedefinieerd dat een hoge waarde ongunstig is. Dit betekent dat het risico van kwalificatieveroudering en verlies van werk groter is naarmate het geel gekleurde gebied verder naar buiten uitslaat.

In het vervolg van deze paragraaf zullen allereerst de risicoprofielen van alle dertien bedriffssectoren worden gepresenteerd. Vervolgens wordt een aantal risicoprofielen gepresenteerd van de beroepssegmenten en opleidingstypen die het hoogst scoren op één van de specifieke risicofactoren.

\section{Bedrijfssector}

In de sector landbouw en visserij blijkt vooral de krimpende werkgelegenheid het risico op verlies van werk te vergroten. In hoofdstuk 4 is er reeds op gewezen dat deze krimpende werkgelegenheid de komende jaren voor een belangrijk deel het gevolg is van de verwachte krimp in de varkenssector. Uit het risicoprofiel blijkt verder dat er in de landbouw en visserij slechts weinig aan scholing wordt gedaan en dat de fysieke belasting binnen de sector relatief groot is. In de sector chemie is er op geen enkel punt sprake van uitzonderlijke risico's op kwalificatieveroudering. Bij vrijwel alle risicofactoren liggen de scores rond het gemiddelde. Dit duidt erop dat de scholingsinspanningen en de functionele flexibiliteit van de werkenden in deze sector redelijk in evenwicht zijn met de risico's op kwalificatieveroudering. Omdat er in de chemie bovendien geen sprake is van werkgelegenheidskrimp, blijven de risico's van verlies op werk voor degenen die in deze sector werkzaam zijn beperkt.

In de sector energit is sprake van relatief snelle technologische en organisatorische ontwikkclingen, een relatief geringe functionele flexibiliteit en hoge psychische belasting. De sector bouw en onroerend goed wordt daarentegen gekenmerkt door een hoge fysieke belasting en een verwachte krimp van de werkgelegenheid. In beide sectoren zijn de risico's op kwalificatieveroudering derhalve groot. In de sector transport en communicatie is het risico van kwalificatieveroudering vooral aanwezig als gevolg van de hoge psychische belasting, de geringe scholingsinspanningen en een beperkte functionele flexibiliteit van werkenden. Ondat de sector metaal-en elektrotechniek op bijna alle factoren net iets boven het gemiddelde scoort is het totaal risico op kwalificatieveroudering ook voor deze sector vrij groot. 
Figuur 6.1

Het risico van verlies van werk naar bedrijfssector
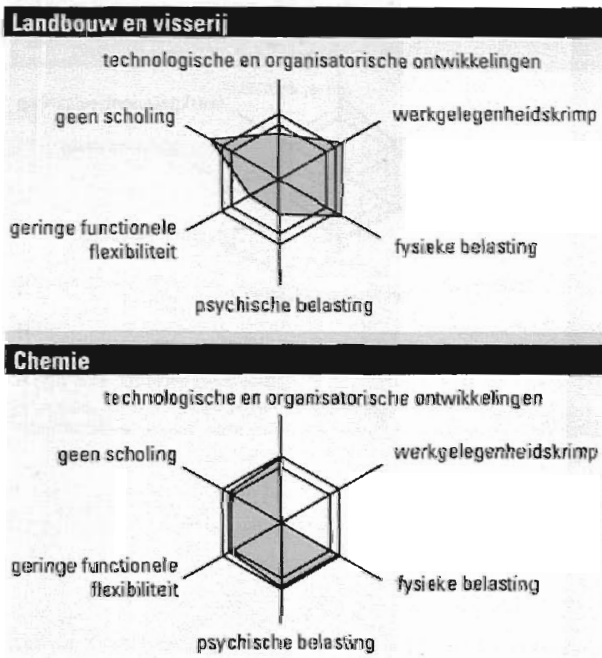

\section{Overige industrie}

technologische en organisatorische ontwikkelingen

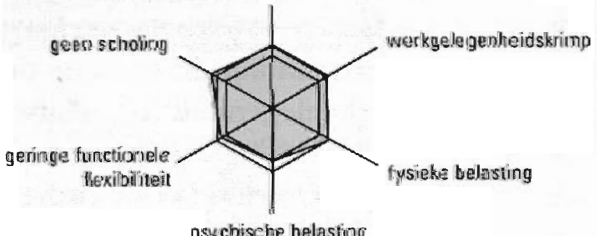

psychische belasting

\section{Bouw en onroerend goed}

technologische en organisatorische ontwikkelingen

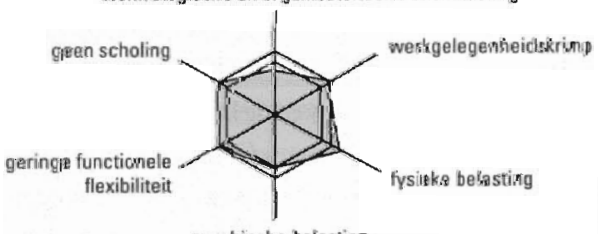

psychische belasting

\section{Transpont en communicatie}

technologische en organisatorische ontwikkelingen

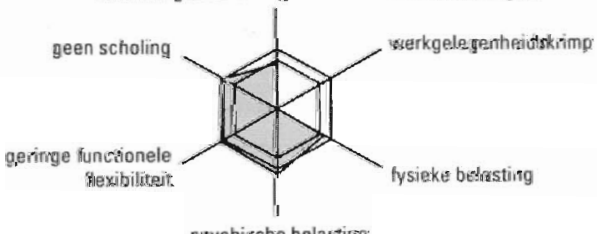

Bsychische bolasting

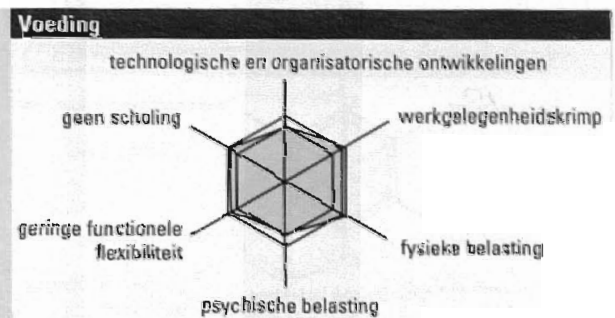

\section{Metaal-en elektrotechniek}

technologische en arganisatorische ontwikkelingen

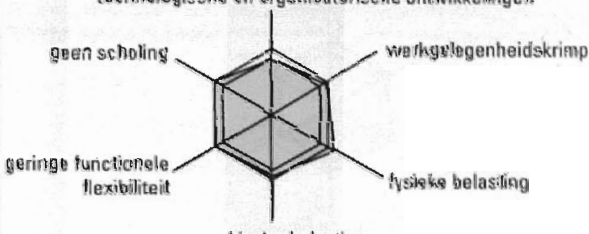

psychische belasting

\section{Energie}

technologische en organisatorische ontwikkelingen

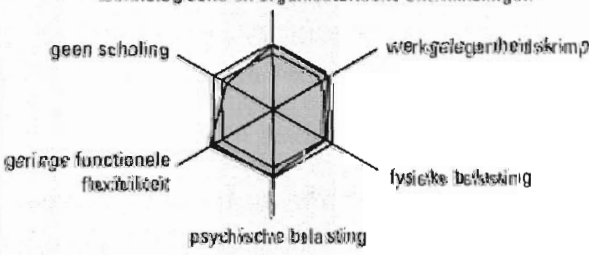

\section{Handel en reparatie}

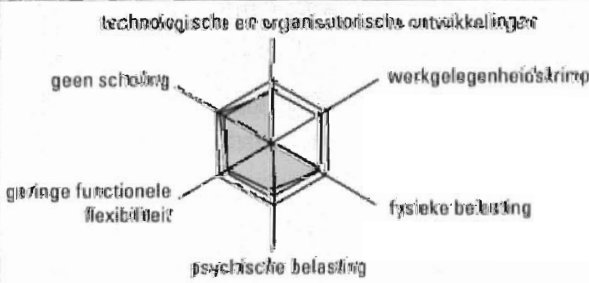

\section{Bank- en verzekeringswezen}

technologische en organisatorische antwikkelingen

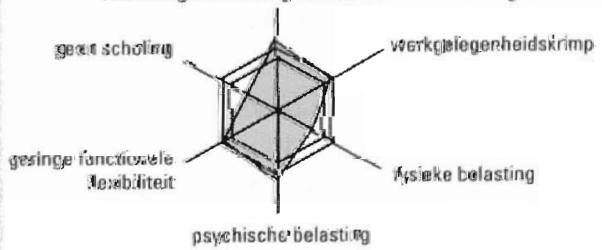



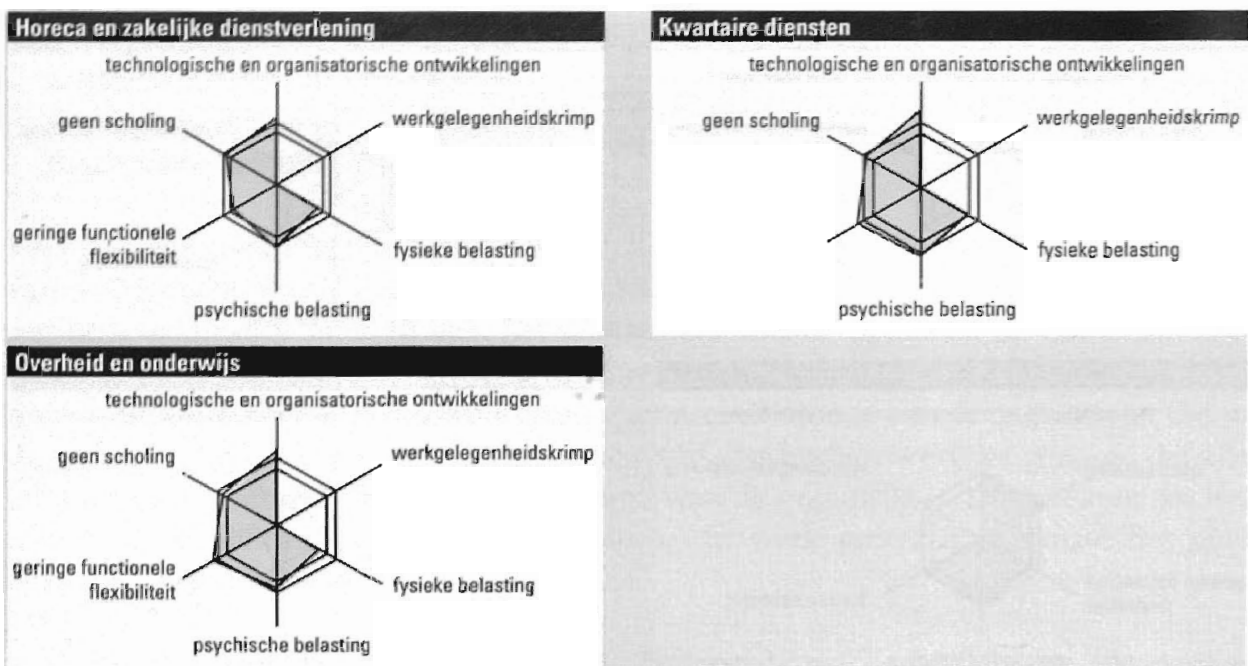

Een relatief hoge psychische belasting is ook een belangrijke risicofactor in de sectoren bank-en verzekeringswezen, horeca en zakelijke dienstverlening en kwartaire diensten. De sector bank- en verzekeringswezen wordt naar verwachting bovendien de komende jaren geconfronteerd met een licht krimpende werkgelegenheid en relatief snelle technologische en organisatorische ontwikkelingen. Binnen de sector boreca en zakelijke dienstverfening hangen de risico's van kwalificatieveroudering vooral samen met de relatief hoge psychische belasting en de technologische en organisatorische vernieuwingen. Datzelfde geldt in versterkte mate voor de sector kwartaire diensten. In deze sector worden snelle technologische en organisatorische ontwikkelingen bovendien gecombineerd met een relatief geringe functionele flexibiliteit van de werkenden en geringe scholingsinspanningen. Voor de sector voeding wordt de komende jaren een vrij forse werkgelegenheidskrimp verwacht. Bovendien is de fysieke belasting voor veel werkenden in deze sector relatief hoog. In de sector overbeid en onderwijs hangen de risico's van kwalificatieveroudering deels samen met de technologische en organisatorische vernieuwingen in deze sector en de geringe functionele flexibiliteit van de werkenden. Voor de sector bandel en reparatie zijn er relatief weinig risico's op kwalificatieveroudering.

\section{Beroep}

In deze subparagraaf wordt het risicoprofiel gepresenteerd van die beroepssegmenten die op één van de onderscheiden risicofactoren het grootste risico op kwalificatieveroudering hebben. Het risicoprofiel is net als bij de bedrijfssectoren opgesteld rondom zes risicofactoren. In plaats van naar snelle technologische en organisatorische ontwikkelingen op sectomiveau te kijken is hier gekeken naar de mate van informatisering van de werkzaamheden in het desbetreffende beroepssegment. Ook zijn de arbeidsmarktontwikkelingen anders benaderd. Er is niet gekeken nar de (netto) werkgelegenheids- 


\section{Hoge fysieke belasting en hoge baanvernietiging}

Lagere technische beroepen

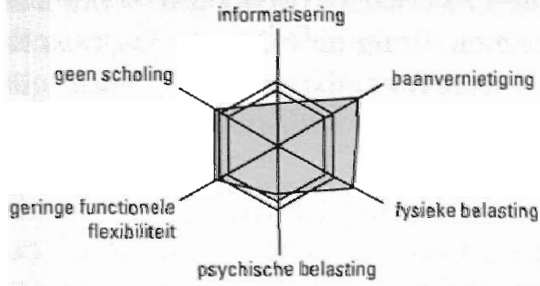

Hoge psychische belasting

\section{Managers (wetenschappelifk werk- en denkniveau)}

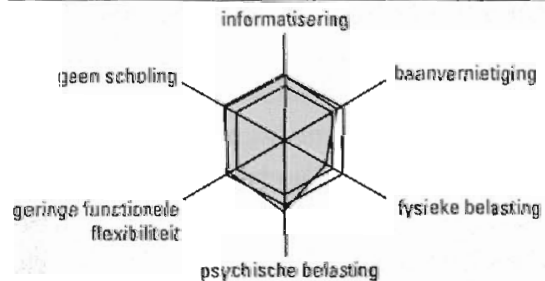

Snelle informatisering

Hogere administratieve, commerciële, economische beroepen

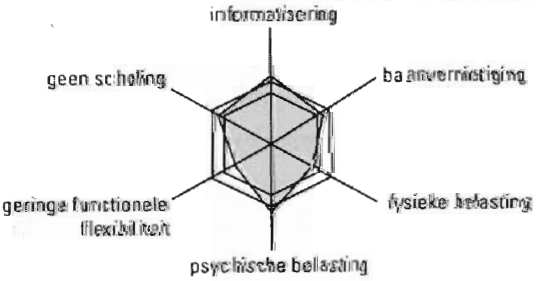

Tekort aan scholing

\section{Middelbare verzorgende beroepen}

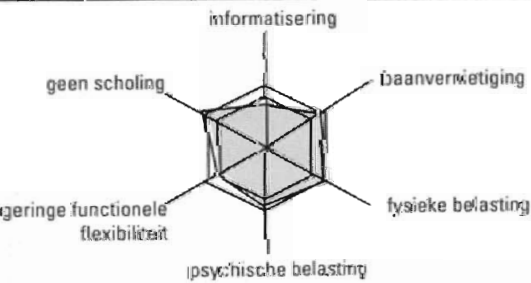

Geringe functionele flexibiliteit

\section{Hogere (para)medische beroepen}

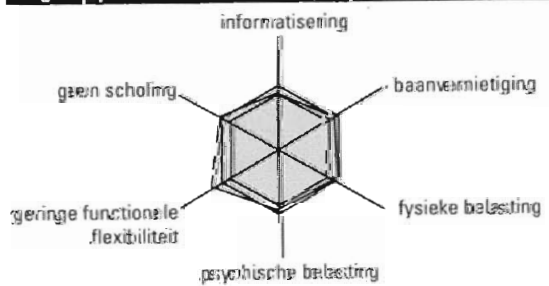

\section{Middelbare technische-beroepen}

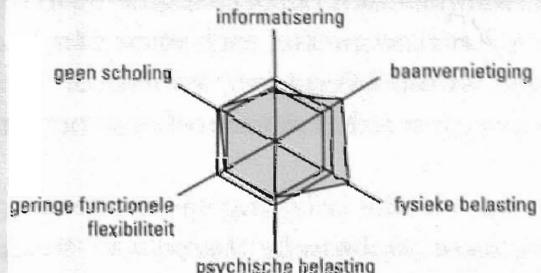

psychische belasting
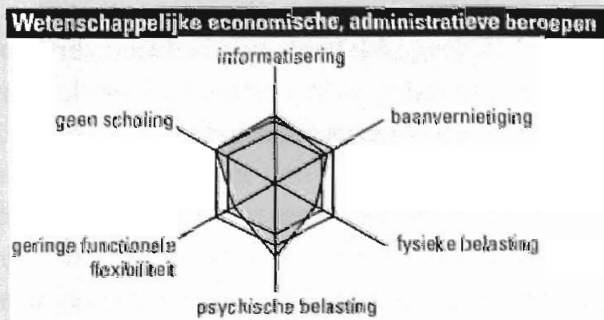

\section{Elementaire beroopen}

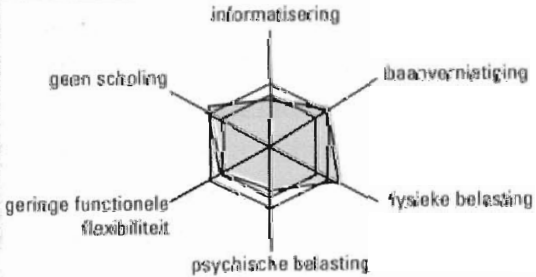

psychische belasting

\section{Hogere pedangagische beroepen}

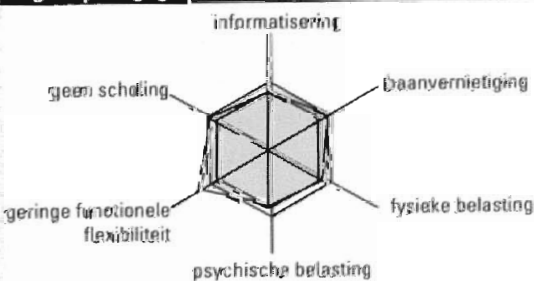


krimp, maar naar de totale baanvernietiging in alle bedrijfssectoren waarin sprake is van een krimpende werkgelegenheid voor het desbetreffende beroepssegment.

Voor elke risicofactor zijn twee beroepssegmenten met een relatief groot risico opgenomen. Wanneer een beroepssegment op meer dan één risicofactor de hoogste score laat zien, is het risicoprofiel toch maar één keer opgenomen. In figuur 6.2 in de Statistische Bijlage wordt overigens, voorzover beschikbare gegevens dat toelaten, voor elk beroepssegment het risicoprofiel gepresenteerd.

Een hoge fysieke belasting speelt met name een rol voor de werkenden in de lagere en middelbare techniscbe beroepen. Beide beroepssegmenten zullen bovendien de komende jaren geconfronteerd worden met de hoogste baanvernietiging. Bovendien is de scholingsdeelname van de werkenden in deze beroepen beperkt. Werkenden in de lagere technische beroepen hebben ten slotte nog een relatief beperkte functionele flexibiliteit. De risico's op verlies van werk vanwege kwalificatieveroudering zijn derhalve in deze beroepssegmenten groot.

Psychische belasting is vooral cen risicofactor voor werkenden in beroepen op een hoger niveau. Vooral managers met een wetenschappelijk werk-en denkniveau en werkenden met een wetenschappelijk economisch, administratief beroep combineren de hoge psychische belasting met een relatief beperkte scholingsinspanning en een relatief hoge mate van informatisering van de werkzaamheden. De managers met een wetenschappelijk werk- en denkniveau blijven bovendien opmerkelipk genoeg achter qua functionele flexibiliteit.

Een hoge mate van informatisering is de belangrijkste risicofactor voor werkenden in de wetenschappetijke economische, administratieve beroepen 43 en de bogere administratieve, commerciële, economische beroepen. Voor beide beroepssegmenten geldt bovenclien dat de psychische belasting relatief hoog is.

Het achterblijven van de scholingsinspanningen vormt voor werkenden in de middelbare verzorgende en de elementaire beroepen de belangrijkste risicofactor. Door beide groepen werkenden wordt een geringe scholingsinspanning gecombineerd met een relatief hoge fysieke belasting.

Een geringe functionele flexibiliteit vormt met name een risico voor de werkenden in de bogere (para)medische beroepen en de bogere pedagogische beroepen. In beide beroepssegmenten is bovendien sprake van een relatief geringe scholingsinspanning. Werkenden in de bogere pedagogische beroepen worden daabij ook nog geconfronteerd met een relatief hoge baanvernietiging.

43 Het risicoprofiel van dit beroepssegnent is reeds weergegeven 
In deze subparagraaf zal worden gekeken naar de risicoprofielen van een aantal opleidingstypen. Hierbij is net als voor de beroepen uitgegaan van de twee opleidingstypen die op een bepaalde risicofactor de meest ongunstige score hebben. Wanneer een opleidingstype op meer dan een risicofactor de hoogste score laat zien is het risicoprofiel toch maar een keer opgenomen. In figuur 6.3 in de Statistische Bijlage is, mits de beschikbare cijfers dit toelieten, voor elk opleidingstype het risicoprofiel weergegeven.

Qua fysieke belasting springen de opleidingstypen VMBO techniek en VMBO landbouw en natuurlijke omgeving eruit. De relatief hoge fysieke belasting wordt in beide gevallen gecombineerd met zowel een hoge baanvernietiging, als een geringe scholingsinspanning, als een geringe functionele flexibiliteit. De risico's van kwalificatieveroudering voor de werkenden met deze opleidingsachtergronden zijn derhalve groot.

Een hoge psychische belasting is de belangrijkste risicofactor voor werkenden met een opleiding WO economie of WO techniek. Voor werkenden met een opleiding WO techniek worden bovendien op hun werkplek geconfronteerd met een relatief hoge mate van informatisering. Belangrijkste verschilpunt tussen wO tecbniek en WO economie is dat werkenden met WO techniek een relatief geringe functionele flexibiliteit hebben en weinig aan scholing deelnemen, waar werkenden met een WO economie opleiding juist relatief flexibel zijn en zich ook redelijk inspannen op het gebied van scholing.

De werkenden met een opleiding WO techniek of HBO economie hebben vooral te maken met een hoge mate van informatisering. Beide groepen werkenden combineren dit met een relatief geringe functionele flexibiliteit en een relatief hoge psychische belasting. De werkenden met een opleiding WO techniek volgen bovendien relatief weinig scholing.

Mer een hoge baanvernietiging worden met name werkenden met alleen basisonderwijs en een opleiding VMBO landbouw en naturrlijke omgeving ${ }^{44}$ geconfronteerd. Eerder bleek al dat werkenden met een opleiding VMBO landbouw en natuurlijke omgeving te maken hebben met relatief hoge fysieke belasting. Bovendien zijn zij wat minder functioneel flexibel en doen zij relatief weinig aan scholing. Ook de groep werkenden met slechts basisonderwijs doet overigens relatief weinig aan scholing. Bovendien is hun functionele flexibiliteit gering. Werkenden met een opleiding MBO landbouw en natuurlijke omgeving en $V M B O$ zorg en welzijn 45 lopen met name risico ondat zij relatief weinig aan scholing deelnemen. Degenen met een opleiding MBO landbouw en natuurlike omgeving worden bovendien geconfronteerd met een hoge fysieke belasting. Wanneer wordt gekeken naar de functionele flexibiliteit van werkenden dan blijken met name degenen met een opleiding HBO landbouw of VMBO zorg en welzijn achter te blijven. Werkenden met een opleiding VMBO zorg en welzijn hebben bovendien te maken met een relatief hoge baanvernietiging, geringe scholingsdeelname en een hoge fysieke belasting. Werkenden met een opleiding HBO landbouw hebben te maken met een hoge mate van informatisering.

44 Het risicoproftel voor dit opleidingstype is reeds weergegeven. 45 Het risicoprofiel voor dit opleidingstype is reeds weergegeven. 
Het risico op verlies van werk naar opleidingsrichting

\section{Hoge fysieke belasting}

\section{VMBO techniek}

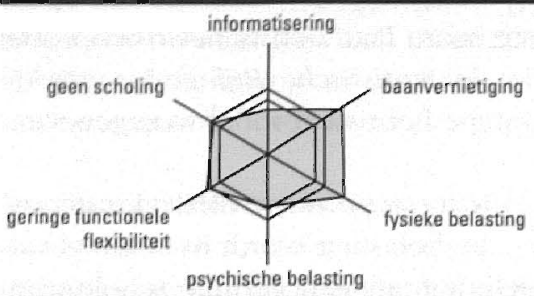

Hoge psychische belasting

\section{WO economis}

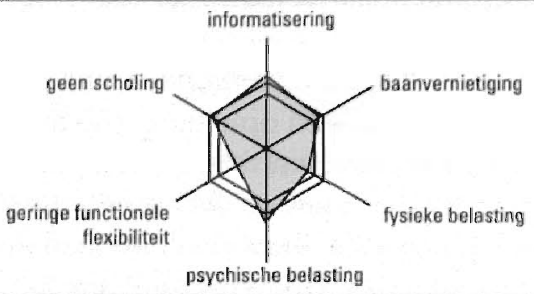

Snelle informatisering

\section{HBO economie}

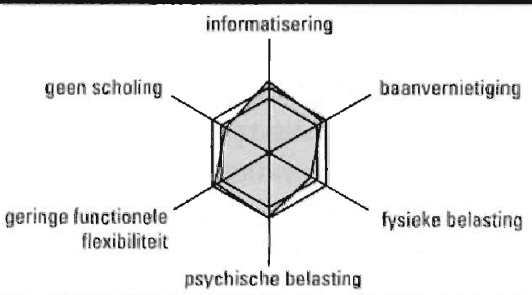

Tekort aan scholing

MBO landhouw en natuurlifke omgeving

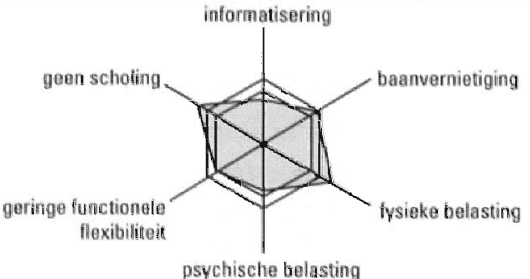

Geringe functionele flexibilitait

\section{HBO landbouw}

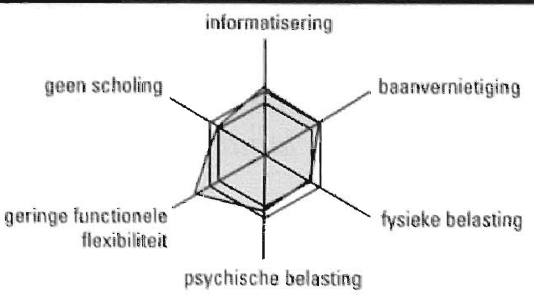

\section{VMBO landbouw en natuurlifke omgeving}

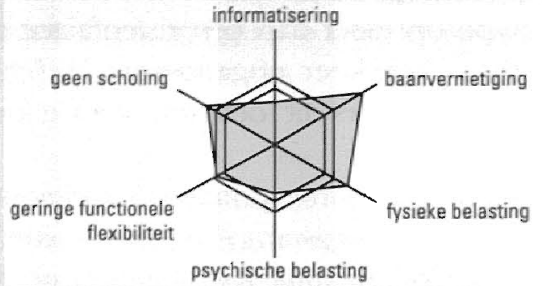

\section{WO techniek}

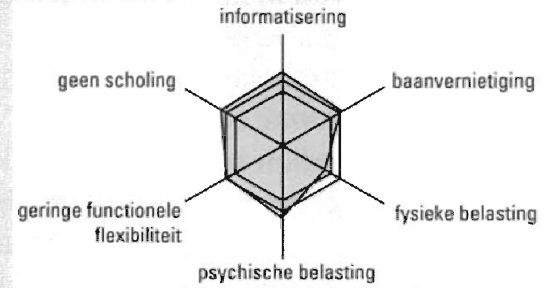

Hoge baanvernietiging

\section{Basisonderwilis}

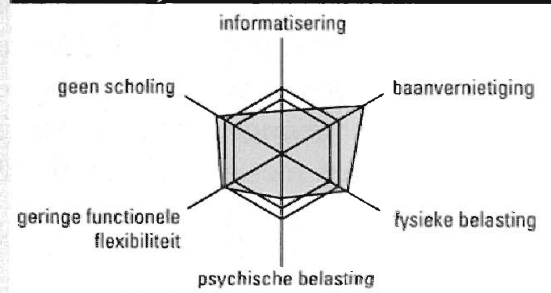

\section{VMBO zorg en welzijn}

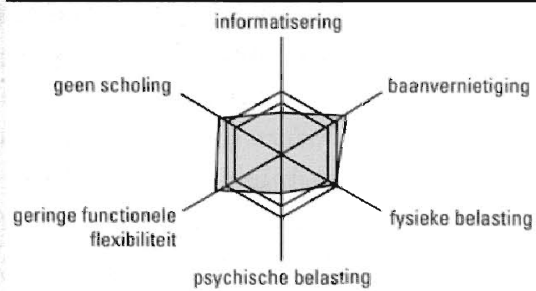




\subsection{Potentiële doelgroepen}

In de vorige paragraaf is reeds een indicatie gegeven van de bedrijfssectoren, beroepssegmenten en opleidingstypen waarin de werkenden tegelijkertijd met verschillende risicofactoren worden geconfronteerd. Om een scherper beeld te krijgen van de groepen werkenden die in onvoldoende mate door scholing of functionele flexibiliteit tegenwicht kunnen bieden aan de risico's op kwalificatieveroudering, worden in deze paragraaf paarsgewijze vergelijkingen gemaakt van enerzijds de risicofactoren en anderzijds de factoren die het risico op kwalificatieveroudering kunnen verminderen. Een krimpende werkgelegenheid of hoge baanvernietiging zal immers vooral leiden tot verlies van werk wanneer scholingsinspanningen en/of functionele flexibiliteit van de werkenden tekortschieten om de negatieve gevolgen ervan te beperken.

\section{Bedrijfssector}

Figuur 6.4 geeft een overzicht van de mate waarin de scholingsinspanningen in bepaalde bedrijfssectoren tekortschieten vanuit een bepaald risico op kwalificatieveroudering dat de werkenden in de desbetreffende sector lopen. In de figuur is een viertal spreidingsdiagrammen weergegeven. In elk van deze spreidingsdiagrammen wordt telkens een vak onderscheiden waarin zich de sectoren bevinden die te maken hebben met een tekortschietende scholingsdeelname gezien de mate waarin een bepaalde risicofactor zich manifesteert. In de figuur is het zogenaamde risicovlak het donkerst gekleurd. Naamate de achtergrondkleur donkerder wordt nemen de risico's voor de werkenden in sectoren verder toe. Zo komen de sectoren landbouw en visserij, overige industrie, voeding, metaal-en elektrotechniek en bouw en onroerend goed naar voren als de bedrijfssectoren waarbinnen de scholingsdeelname te gering is om een tegenwicht te kunnen bieden aan de relatief hoge fysieke belasting, die een grote groep werkenden in deze sectoren op een bepaald moment noodzaakt om van functie te veranderen.

Naar aanleiding van dit diagram mag echter niet direct de illusie worden gewekt dat louter het volgen van extra scholing voldoende zou zijn om voor de werkenden in genoemde sectoren het risico van verlies van werk weg te nemen. Wel kan bij- of omscholing werkenden helpen om, wanneer zij zich vanwege de hoge fysieke belasting niet meer in hun huidige functie kunnen handhaven, elders aan de slag te geraken. Scholing kan overigens ook dienen ter voorkoming van slijtage wanneer deze betrekking heeft op het beter, veiliger en gezonder leren werken.

Wanneer de scholingsdeelname van werkenden wordt afgezet tegen de psychische belasting, dan komen met name de sectoren transport en communicatie, kwartaire diensten en metaal- en elektrotechniek naar voren als de sectoren was de behoefte aan additionele scholing het grootst is.

Wordt de scholingsdeelname gerelateerd aan de mate waarin er in een sector sprake is van technologische en organisatorische vernieuwingen, dan komen de sectoren overige industrie en kwartaire diensten naar voren als de sectoren waarin het risico op verlies van werk het grootst is. Een relatief geringe scholingsdeelname wordt gecombineerd met relatief snelle technologische en organisatorische ontwikkelingen. 
Bedrijfssectoren met een tekortschietende scholingsdeelname gezien de mate waarin risicofactoren zich manifesteren.

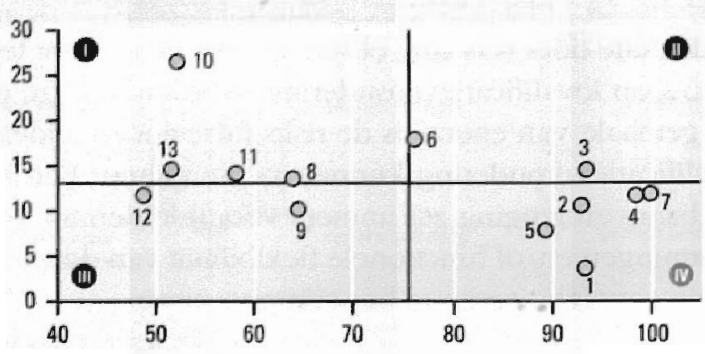

Fysieke belasting

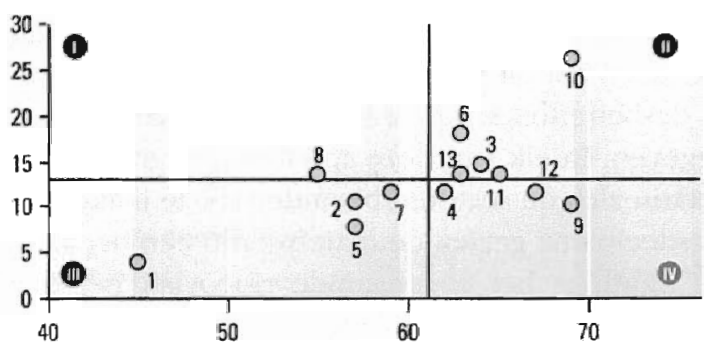

Psychische belasting

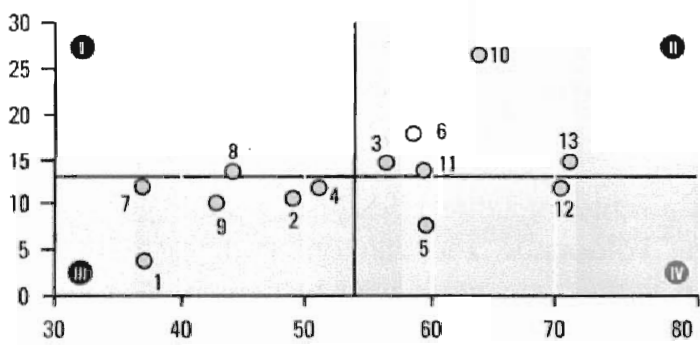

1 Landbouw en visserii

2 Voeding

3 Chemie

4 Metaal- en elektrotechniek

5 Overige industrie

6 Energie

7 Bouw en onroerend goed

8 Handel en reparatie

9 Transport en communicatie

10 Bank- en verzekeringswezen

11 Horeca en zakelijke dienstverlening

12 Kwartaire diensten

13 Overheid en onderwijs

Technologische en organisatorische ontwikkelingen

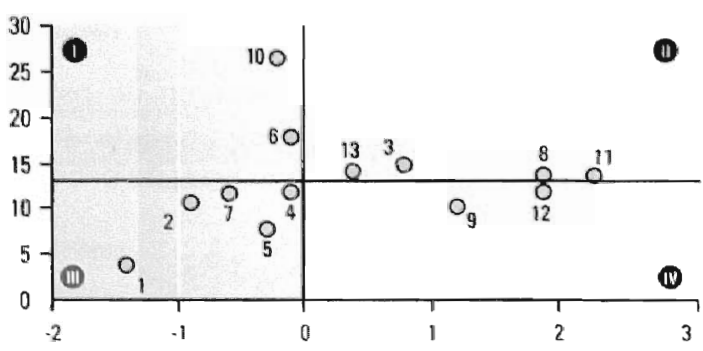

Werkgelegenheidsontwikkeling 
In de sector kwartaire diensten wordt overigens nog wel redelijk wat aan scholing gedaan. Ruim 13\% van de werkenden in de sector volgt scholing. Gezien de snelle ontwikkelingen op technologisch en organisatorisch vlak is in deze sector echter de kans groot dat dit scholingsdeelname-percentage toch op een te laag niveau ligt om een adequaat tegenwicht te kunnen bieden aan de risico's van kwalificatieveroudering.

De werkenden in de sectoren landbouw en visserij, overige industrie, voeding, metaalen elektrotechniek en bouw en onroerend goed lopen het grootste risico op verlies van werk, ondat er via on- of bijscholingsactiviteiten onvoldoende wordt ingespeeld op de verwachte werkgelegenheidskrimp in deze sectoren.

De potentiële doelgroepen voor scholing gericht op behoud van werk die op basis van de voorgaande analyses kunnen worden onderscheiden zijn allereerst de werkenden in de sector overige industrie. De kans dat de relatief geringe scholingsdeelname de werkenden in deze sector wapent tegen de snelle technologische en organisatorische ontwikkelingen, de forse werkgelegenheidskrimp en de hoge fysieke belasting is erg klein. Ook de werkenden in de sector metaal-en elektrotechniek vormen een belangrijke doelgroep voor het scholingsheleid gericht op behoud van werk. De relatief hoge fysieke en psychische belasting en de krimpende werkgelegenheid vagen een hogere scholingsdeelname. Andere doelgroepen die in aanmerking komen voor extra scholing zijn de werkenden in de bedrijfssectoren landbouw en visserij, voeding en bouw en onroerend goed.

In figuur 6.5 is een viertal spreidingsdiagrammen weergegeven waarin de verschillende risico's op kwalificatieveroudering die de werkenden in een bepaalde sector lopen zijn afgezet tegen de functionele flexibiliteit van werkenden in de desbetreffende bedrijfssector. Bij de werkenden in de sectoren metaal- en elektrotechniek, energie en bouw en onroerend goed is de functionele flexibiliteit te laag gezien de mate warin zij te maken krijgen met fysieke belasting. Dit vergroot het risico op verlies van werk, omdat men, wanneer men het werk vanwege de hoge fysieke belasting niet meer kan uitoefenen, moeilijk kan uitwijken naar een andere baan.

In de energiesector is de functionele flexibiliteit van de werkenden zo gering dat zij natwelijks opgewassen zijn tegen de risico's die zij lopen, zowel als gevolg van fysieke als psychische belasting. Andere sectoren waar de functionele flexibiliteit van de werkenden onvoldoende tegenwicht biedt aan de relatief hoge psychische belasting zijn banken verzekeringswezen, metaal- en elektrotechniek, overheid on onderwijs en vooral kwartaire diensten en transport en communicatie.

Een confrontatie van de technologische en organisatorische ontwikkelingen die er in een sector plaatsvinden met de functionele flexibiliteit van de werkenden maakt duidelijk dat met name binnen de sectoren overheid en onderwijs en kwartaire diensten er vanuit dit oogpunt grote risico's zijn op verlies van werk. De kans dat de werkenden in deze sectoren niet flexibel genoeg zijn om op een goede wijze om te gaan met de snelle technologische en organisatorische ontwikkelingen is relatief groot.

Ook in de sectoren energie en bank-en verzekeringswezen schiet de functionele flexibiliteit mogelijk tekort. 
Bedrijfssectoren met een tekortschietende functionele flexibiliteit gezien de mate waarin risicofactoren zich manifesteren

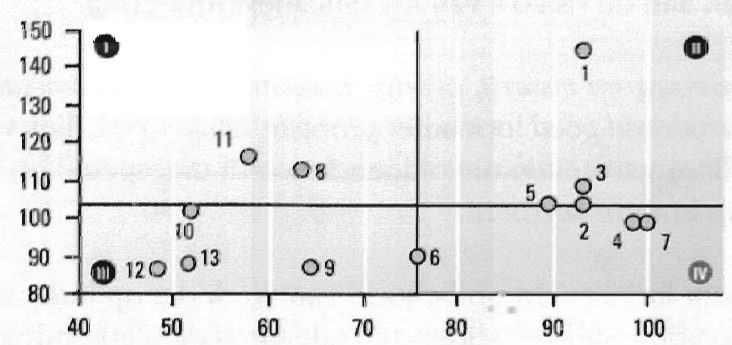

Fysieke belasting

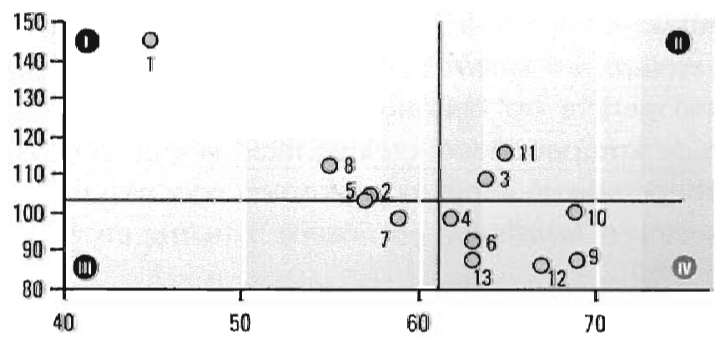

Psychische belasting

1 Landbouw en visserij

2 Voeding

3 Chemie

4 Metaal- en elektrotechniek

5 Overige industrie

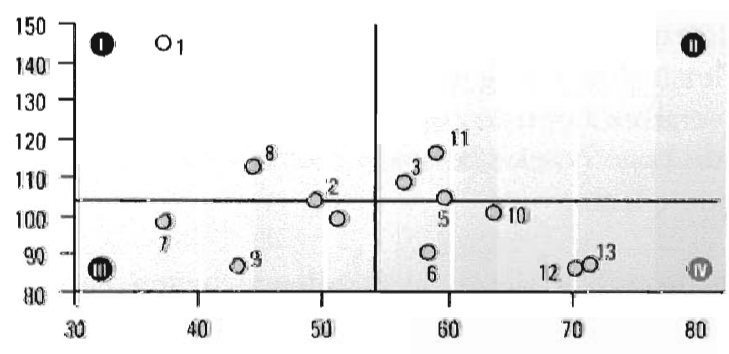

6 Energie

7 Bouw en onroerend goed

8 Handel en reparatie

9 Transport en communicatie

10 Bank-en verzekeringswezen

11 Horeca en zakelijke dienstverlening

12 Kwartaire diensten

13 Overheid en anderwijs

Technologische en organisatorische ontwikkelingen

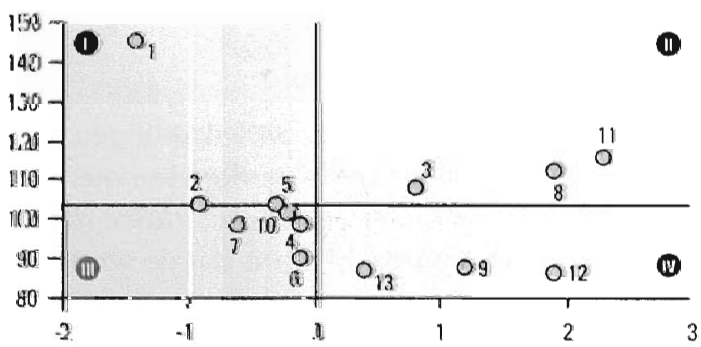

Werkgelegenheidsontwikkeling 
Wordt de functionele flexibiliteit van werkenden afgezet tegen de ontwikkeling van de werkgelegenheid binnen een sector, dan komen de sectoren energie, metaal-en elektrotechniek, bouw en onroerend goed en bank-en verzekeringswezen naar voren als de sectoren waarin de kans dat de functionele flexibiliteit tekortschiet het grootst is.

De sector energie komt uit elke confrontatie naar voren als een van de sectoren waarbinnen werkenden te maken hebben met een relatief hoge kans dat hun functionele flexibiliteit tekortschiet. Zowel qua fysieke als psychische belasting als ook wat betreft technologische en organisatorische ontwikkelingen en werkgelegenheidskrimp is de positie van de sector relatief ongunstig. De functionele flexibiliteit die hier tegenover staat is relatief gering. Dat kan voor grote problemen zorgen. Werkenden in de sector energie behoren daardoor tot de belangrijkste doelgroep voor beleid gericht op het vergroten van de functionele flexibiliteit van de werkenden. Ook bij de werkenden in de sectoren bank- en verzekeringswezen en metaal en elektrotechniek dient er meer aandacht te komen voor een beleid geticht op het vergroten van de functionele flexibiliteit van de werkenden.

\section{Beroepen}

In figuur 6.6 worden de resultaten weergegeven van de confrontatie van de verschillende risicofactoren voor de werkenden in een bepaald beroepssegment met de mogelijke remedies tegen kwalificatieveroudering: scholing en functionele flexibiliteit.

In de lagere technische, elementaire en middelbare verzorgende beroepen stat tegenover een hoge fysieke belasting een relatief geringe scholingsdeelname. De werkenden in de middelbare technische, bogere (para)medische en lagere verzorgende beroepen doen weliswaar wat meer aan scholing dan gemiddeld, maar de fysieke belasting is zo hoog dat meer aandacht voor scholing om hen te wapenen tegen mogelijke uitval uit hun huidige functie waarschijnlijk erg raadzaam is.

Wordt scholingsdeelname afgezet tegen psychische belasting dan blijken managers (wetenschappelijk werk- en denkniveau) en werkenden in de middelbare verzorgende, bogere techniscbe, bogere en middelbare (para)mediscbe en wetenschappelijke economiscbe, administratieve beroepen tot de belangrijkste doelgroepen te behoren Overigens zou de hoge werkdruk voor deze groepen werkenden juist een oorzaak kunnen zijn van de geringe scholingsdeelname. Voor managers (wetenschappelijk werk- en denkniveau) en werkenden in de bogere technische en wetenschappelijke economiscbe, administratieve beroepen wordt de relatief geringe scholingsdeelname overigens ook nog gecombineerd met een hoge mate van informatisering van werkzamheden.

Dit duidt er op dat met name bijscholing op het gebied van computergebruik de risico's op kwalificatieveroudering mogelijk beperkt. Wel is het noodzakelijk dat voor dergelijke scholing tijd beschikbaar komt. Het beperken van de tijdsdruk lijkt dus de eerste prioriteit voor de hier genoemde beroepssegmenten. Andere groepen werkenden die te maken hebben met een relatief geringe scholingsdeelname gezien de snelle informatisering zijn de werkenden in de middelbare juridiscbe, besturtijke beveiligingsherorpen, de bogere administratieve, commerciële, economiscbe beroepen en de middelhare administratieve, commerciële beroepen. 
Voor werkenden in de lagere en bogere technische beroepen wordt een relatief hoge baanvernietiging verwacht. Omdat de scholingsdeelname in deze beide arbeidsmarktsegmenten wat achterblifft, ontstaat een riskante situatie. Alleen extra scholing zal niet voldoende zijn om deze risico's af te wenden maar zij biedt wel enkele mogelijkheden. Bijscholing kan werkenden bijvoorbeeld behoeden voor verlies van werk als gevolg van de baanvernietiging.

\section{Figuur 6.6}

Beroepssegmenten met de grootste kans dat de scholing tekortschiet gezien de mate waarin er sprake is van risicofactoren

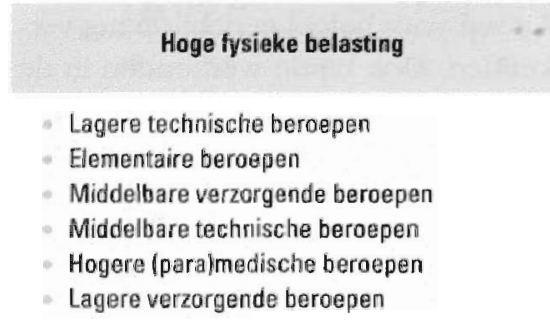

Snelle informatisering

Managers (wetenschappelijk werk- en denkniveau)

Hogere technische beroepen

Wetenschappelijke economische, administratieve beroepen

Middelbare juridische, bestuurlijke beveiligingsberoepen

Hogere administratieve, commerciële economische beroepen

Middelbare administratieve, commerciële beroepen

\section{Hoge psychische belasting}

- Managers (wetenschappelijk werk- en denkniveau)

Middelbare verzargende beroepen

Hogere technische beroepen

Hogere (para)medische beroepen

Middelbare (para)medische beroepen

Wetenschappelijke economische,

administratieve beroepen

\section{Hoge baanvernietiging}

Lagere technische beroepen

Hogere technische beroepen

Middelbare technische beroepen

Onscholing kan in geval van verlies van werk helpen bij het vinden van een andere functie. Overigens lopen ook de werkenden in de middelbare technische beroepen aanzienlijke risico's op verlies van werk door kwalificatieveroudering. Weliswaar doen zij iets meer aan scholing dan de gemiddelde werkende, maar de baanvernietiging is dusdanig dat de kans groot is dat de scholingsdeelname toch tekort schiet. Ook deze groep werkenden kan als doelgroep voor het scholingsbeleid worden aangemerkt.

Al met al zijn het de technici die het meest in aanmerking komen voor scholing die gericht is op het tegengaan van kwalificatieveroudering. Zij komen naar voren als belangrijke tisicogroep op vrijwel alle afzonderlijke risicofactoren. Dat wil zeggen dat het risico van verlies van werk als gevolg van $\mathrm{kwalificatieveroudering} \mathrm{voor} \mathrm{de} \mathrm{technici}$ 
relatief groot is. Aangezien zij daarbij relatief weinig aan scholing doen, zullen zij niet gemakkelijk ergens anders werk kunnen vinden.

In figuur 6.7 wordt een beeld gegeven van de mate waarin werkenden in bepaalde beroepssegmenten voldoende functioneel flexibel zijn om een mogelijk verlies van werk als gevolg van kwalificatieveroudering tegen te gaan. Vooral bij de werkenden in lagere technische beroepen is de functionele flexibiliteit onvoldoende om tegenwicht te bieden aan de hoge fysieke belasting. Daamaast behoren werkenden in de lagere (para)medische beroepen, middelbare agrarische beroepen, lagere transportberoepen en de lagere verzorgende beroepen tot de mogelijke doelgroepen voor beleid gericht op het bevorderen van de functionele flexibiliteit. Het bevorderen van de functionele flexibiliteit kan in zekere mate de hoge fysieke belasting voor werkenden in deze beroepen verminderen, doordat zij meer uiteenlopende werkzaamheden gaan verrichten. Hierdoor zal de kans op RSI-achtige ziekteverschijnselen waarschijnlijk afnemen, omdat het lichaam wat afwisselender wordt gebruikt.

Werkenden in bogere juridiscbe, bestuurlijke, beveiligingsberoepen, managers (wetenschappelijk werk- en denkniveau), werkenden in de bogere en wetenschappelijke technische beroepen en werkenden in de wetenschappelijke pedagogische beroepen combineren een hoge psychische belasting met een geringe functionele flexibiliteit. De werkenden in de lagere (para)mediscbe beroepen en de lagere transportberoepen die al met een relatief hoge fysieke belasting te maken hebben, worden ook met een relatief hoge psychische belasting geconfronteerd. De functionele flexibiliteit van de werkenden in deze beroepen is te gering om werkenden afdoende te wapenen tegen de beide risico's.

Voor de werkenden in de bogere juridische, besuurlijke, beveiligingsberoepen is de kans dat de functionele flexibiliteit tekort schiet om optimaal om te kunnen gaan met de relatief snelle informatisering vrij groot. De werkenden in deze beroepen hebben ook te maken met cen hoge psychische belasting wat de risico's op verlies van werk alleen nog maar vergroot. Datzelfde geldt, zij het in mindere mate, voor werkenden in de bogere en wetenschappelijk tecbnische, middelbare juridiscbe, besturlijke beveiligings-, on middelbare taalkundige beroepen.

De werkenden in de lagere technische beroepen zijn relatief weinig functioneel flexibel. Omdat voor deze beroepen in de komende jaren een hoge baanvernietiging wordt verwacht behoren werkenden in deze beroepen tot de doelgroepen voor beleid gericht op het vergroten van de functionele flexibiliteit. Bovendien bleek dat de scholingsinspanningen van de lagere technici achterblijven. Deze ongunstige combinatie van factoren zorgt ervoor dat de vooruitzichten voor de lagere technici somber zijn. Er is dus voldoende reden om wat aan hun scholingsdeelname en functionele flexibiliteit te doen. Ook de werkenden in de middelbare agrarische beroepen, lagere verzorgende beroepen, lagere (para)medische beroepen, wetenschappelijke lechnische beroepen en bogere technische beroepen wacht een hoge baanvernietiging. Gezien hun relatief geringe functionele flexibiliteit zou deze krimp voor problemen kunnen gaan zorgen. Een groter functionele flexibiliteit kan voor de werkenden immers betekenen dat zij zonder al teveel problemen van baan kunnen veranderen mochten zij als gevolg van de krimp hun baan verliezen. 
Figuur 6.7

Beroepssegmenten met de grootste kans dat de functionele flexibiliteit tekortschiet gezien de mate waarin sprake is van risicofactoren

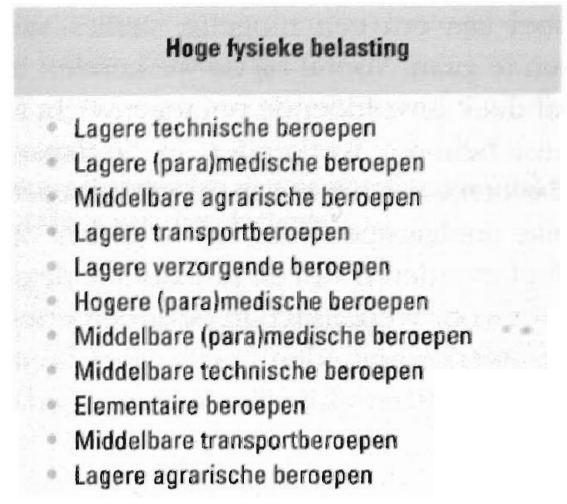

\section{Snelle informatisering}

- Hagere juridische, bestuurlijke beveiligingsberoepen

Wetenschappelijke technische beroepen

Middelbare juridische, bestuurlijke beveiligingsberoepen

Middelbare taalkundige, culturele beroepen

Hogere technische beroepen

Managers (wetenschappelijk werk- en denkniveau)

Wetenschappelijke pedagogische beroepen

- Middelbare beroepen m.b.t. gedrag en maatschappij

\section{Hoge psychische belasting}

\author{
Hogere juridische, bestuurlijke beveiligings- \\ beroepen \\ Managers (wetenschappelijk werk- en \\ denkniveau) \\ Lagere (para)medische beroepen \\ Wetenschappelijke technische beroepen \\ Lagere transportberoepen \\ Wetenschappelijke pedagogische \\ beroepen \\ Hogere technische beroepen \\ Middelbare (para)medische beroepen
}

\section{Hoge baanvernietiging}

Lagere technische beroepen
Middelbare agrarische beroepen
Lagere verzorgende beroepen
Wetenschappelijke technische beroepen
Hogere technische beroepen
Lagere (para)medische beroepen
Middelbare technische beroepen
Lagere agrarische beroepen

Opleiding

Figutr 6.8 geeft die opleidingstypen weer die een verhoudingsgewijs hoog risico lopen op één of meer van de risicofactoren, zonder dat daar een hoge scholingsdeelname tegenover staat. Allereerst wordt fysieke belasting afgezet tegen scholingsdeelname. Vooral werkenden met een relatief lage opleidingsachtergrond lopen het risico dat wanneer zij vanwege de hoge fysieke belasting hun huidige baan niet langer kunnen uitoefenen, zij onvoldoende zijn toegerust om uit te wijken naar ander werk. Met name werkenden met een opleiding VMBO techniek, VMBO landbouw en naturlijke omgeving. MBO landbouw en namulijke omgeving of alleen basisonderwijs behoren tot de doelgroepen voor scholingsbeleid. Wat minder risico lopen werkenden met een opleiding $V M B O$ zorg en welzijn, maar ook deze groep werkenden kan erg gebaat zijn bij enige extra scholing.

Uit de figuur blijkt verder dat vooral hoger opgeleiden een hoge psychische belasting combineren met een relatief geringe scholingsdeelname. Werknemers met een opleiding WO kumst. WO landbour en milierkunde, WO mediscb of WO technick zijn van- 
uit deze optiek de belangrijkste doelgroepen. Zij lopen het risico vanwege de hoge psychische belasting met psychische slijtage te maken te krijgen. Doen zij te weinig aan scholing dan zullen zij minder gemakkelijk uit kunnen wijken naar een andere funcrie. Dat verhoogt het risico op verlies van werk. Ook de werkenden met een opleiding WO sociaal cultureel of wO letteren en theologie bevinden zich in het zogenaamde risicovlak. Ook voor deze categorieën werkenden is extra scholing gericht op het voorkomen van kwalificatieveroudering als gevolg van psychische belasting van groot belang

Figuur 6.8

Opleidingstypen met de grootste kans dat de scholing tekortschiet gezien de mate waarin er sprake is van risicofactoren

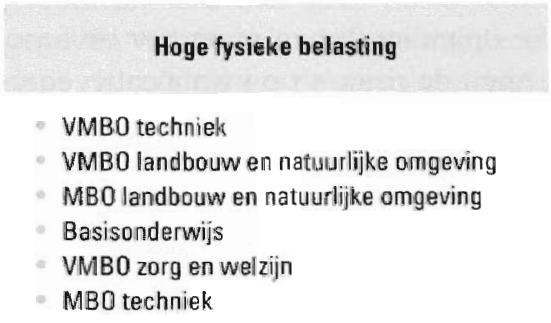

Snelle informatisering

Wo landbouw en milieukunde

Wo techniek

WO kunst

WO sociaal cultureel

Wo letteren en theólogie

WO medisch

WO economie

HBO techniek

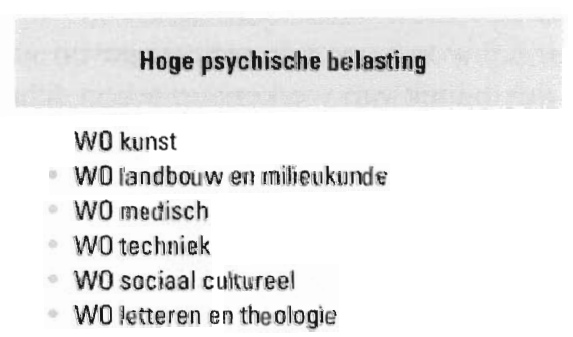

Hoge baanvernietiging

VMBO landbouw en natuurlijke omgeving

Basisonderwijs

VMBO techniek

VMBO zorg en welzijn

HBO kunst

VMBO economie

Wanneer de mate waarin werkenden te maken hebben met informatisering wordt afgezet tegen hun scholingsdeelname, blijkt dat vooral werkenden met een academische opleidingsachtergrond tot de potentiële doelgroepen behoren voor bijscholingsactiviteiten. Werkenden met een opleiding WO landbouw en milieukunde, WO techniek of WO kunst lopen het grootste risico dat hun scholingsdeelname tekortschiel, gezien de mate warin zij worden geconfronteerd met informatisering. Met name bijscholing op het gebied van computergebruik lijkt daarbij zinvol. Ook werkenden met WO srciaal cultured, WO letteren en theologie of WO medisch lopen op dit punt een risico. 
Gezien de hoge baanvernietiging voor werkenden met een opleiding VMBO landbouw en natuurlijke omgeving of basisonderwijs is scholing nodig om deze groepen werkenden van voldoende kwalificaties te voorzien om een positie op de arbeidsmarkt te blijven houden. Omdat deze groepen werkenden relatief weinig aan scholing doen, vormen zij een belangrijke doelgroep voor extra scholing.

Ook de werkenden met een opleiding VMBO techniek, VMBO zorg en welzijn, HBO kunst of $V M B O$ economie behoren tot de categorieën werkenden die een relatief grote kans hebben dat de scholing die zij volgen niet voldoende is om de risico's die een hoge baanvernietiging met zich meebrengt af te dekken. Zij behoren dus eveneens tot de potentiële doelgroepen voor omscholingsactiviteiten.

In figuur 6.9 wordt een overzicht gegeven van die opleidingstypen waarvoor de functionele flexibiliteit van werkenden tekort schiet gezien de risico's op kwalificatieveroudering waarmee zij worden geconfronteerd. Allereerst blijkt dat met name werkenden met een lagere opleidingsachtergrond tot de doelgroepen van een beleid gericht op het bevorderen van de functionele flexibiliteit behoren. Werkenden met een opleiding $V M B O$ techniek, VMBO landbouw en natuurlijke omgeving, basisonderwijs, VMBO zorg en welzijn of MBO techniek vormen hierbij de voorhoede.

Werkenden met HBO landbonw, WO techniek of WO sociaal cultureel hebben een grote kans dat hun functionele flexibiliteit tekortschiet gezien de relatief hoge mate van psychische belasting die hun werk met zich meebrengt. Ook de risico's van informatisering spelen voor werkenden met deze opleidingsachtergronden een belangrijke rol. Het bevorderen van hun functionele flexibiliteit zal mogelijk kunnen voorkomen dat zij op een gegeven moment zonder werk komen te zitten wanneer zij hun huidige werk niet langer adequaat kunnen uitoefenen. Zoals al eerder werd opgemerkt lijkt het voor deze groepen werkenden vooral van belang de tijdsdruk aan te pakken, omdat zo voor

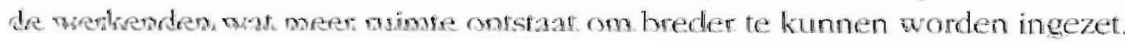

Werkenden met een opleiding VMBO landbouw en naturlijke omgeving, basisonderwijs, VMBO techniek of VMBO zorg en welzijn hebben waarschijnlijk een te geringe functionele flexibiliteit om wanneer zij hun baan kwijtraken vanwege de krimp in de werkgelegenheid uit te kunnen wijken nar een ander segment van de arbeidsmarkt. Het is dus van belang deze groepen werkenden bewust te maken van de risico's die zij lopen en de perspectieven die zij hebben, zodat zij zich mogelijk uit zichzelf al gaan oriënteren op de arbeidsmarkt. Dit om ervoor te zorgen dat men een reëel beeld heeft van de mogelijkheden bij verlies van werk in een andere functie, een ander bedrijf of een ander beroep terecht te kunnen. Het op basis hiervan preventief werken aan de functionele flexibiliteit van werkenden kan verlies van werk als gevolg van werkgelegenheidskrimp tegengaan. 
Opleidingstypen met de grootste kans dat de functionele flexibiliteit tekortschiet gezien de mate waarin er sprake is van risicofactoren

Hage fysieke belasting
- VMBO techniek
- VMBO landbouw en natuurlijke omgeving
- MBO techniek
- Basisonderwijs
VMBO zorg en welzijn
MBO opentare orde en veiligheid
VMBO theorie
- HBO paramedisch

Snelle informatisering

HBO landbouw
WO techniek
HBO economie
HBO techniek
WO sociaal cultureel
WO letteren en theologie
MBO openbare arde en veiligheid

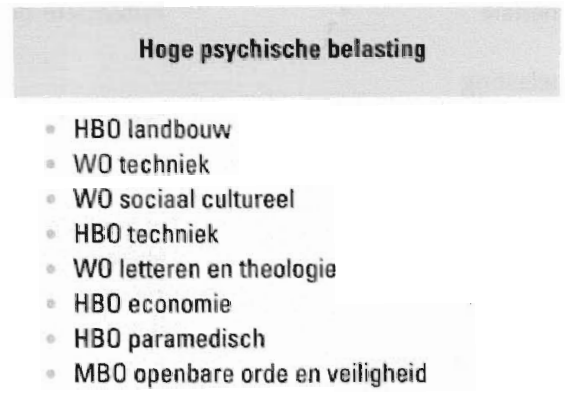

Hoge baanvernietiging
VMBO landbouw en natuurlijke omgeving
Basisonderwijs
MBO landbouw en natuurlijke omgeving
VMBO zorg en welzijn
MBO openbare orde en veiligheid

\subsection{Conclusies}

In tabel 6.1 worden de belangrijkste conclusies van dit hoofdstuk samengevat, door een overzicht te geven van de bedrijfssectoren, beroepssegmenten en opleidingsrichtingen die opvallen door een grote bij- of omscholingsbehoefte, doordat de huidige scholingsinspanningen of de aanwezige functionele flexibiliteit vooralsnog onvoldoende lijken om aan de onderscheiden risicofactoren voldoende tegenwicht te bieden. De tabel geeft ook aan of met name bij- of juist omscholing het risico op verlies van werk zou moeten inperken. Werkenden die te maken hebben met een verhoogd risico op kwalificatieveroudering door de hoge mate van fysieke belasting zullen bijvoorbeek niet in de eerste plaats gebaat zijn bij bijscholing maar vee meer bij omscholing. Indien zij immers als gevolg van fysieke slijtage niet langer in staat zijn hun huidige functie te blijven uitoefenen, is een overstap naar een andere baan noodzakelijk. De overstap naar een andere, fysiek minder veeleisende baan, vereist doorgaans wel substantiële bijscholing' naar een hoger opleidingsniveau of omscholing. 
Tabel 6.1

Segmenten met een (erg) grote bij- of omscholingsbehoefte gezien de tekortschietende scholing en functionele flexibiliteit

\section{Risicodimensie}

Fysieke belasting

Bedrififsectoren

Beroepen

Opleidingen

Psychische belasting

Bedrififssectoren

Beroepen

opleidingen

Informatisering

Bedriffssectoren

Beroepen

Opleidingen

\section{Potentiële doelgroepen}

Bouw en onroerend goed

Lagere technische beroepen

Elementaire beroepen

Middelbare verzorgende beroepen

Lagere verzorgende beroepen

Hogere (para)medische beroepen

Middelbare (para)medische beroepen

VMBO techniek

VMBO landbouw en natuuriijke omgeving

Basisonderwijs

VMBO zorg en welzijn

MBO techniek

Transport en communicatie

Kwartaire diensten

Metaal- en elektrotechniek

Managers (wetenschappelijk werk-

en denkniveau)

Middelbare (para) medische beroepen

Wo techniek

WO sociaal cultureel

wo letteren en theologie

Kwartaire diensten

Managers (wetenschappelijk werk-

en denkniveau)

Hogere technische beroepen

Middelbare juridische, bestururlijke

beveiligingsberoepen

Wo techniek

WO sociaal cultureel

wo letteren en theologie

HBO techniek

\section{Vereiste scholing}

omscholing

omscholing

omscholing

omscholing

omscholing

omscholing

omscholing

omscholing

omscholing

omscholing

omscholing

omscholing

om/bijscholing om/bijscholing om/bijscholing

bijscholing om/bijscholing

bijscholing bijscholing bijscholing

bijscholing

bijscholing

bijscholing

om/bijscholing

bijscholing

bijscholing

bijscholing

bijscholing 
Tabel 6.1 (vervolg)

Segmenten met een (erg) grote bij- of omscholingsbehoefte gezien de tekortschietende scholing en functionele flexibiliteit

Risicodimensie

Werkgelegenheidskrimp

en reallocatie

Bedrifssectoren

Beroepen

Opleidingen

\section{Potentiële doelgroepen}

\section{Vereiste scholing}

Metaal- en elektrotechniek

Bouw en onroerend goed

Lagere technische beroepen

Hogere technische beroepen

Middelbare technische beroepen

VMBO landbouw en natuurlijke

omgeving

Basisonderwijs

VMBO techniek

VMBO zorg en welzijn omscholing

omscholing

omscholing

omscholing

omscholing

omscholing

substantièle

bijscholing

omscholing

omscholing

Werkenden die te maken hebben met hoge psychische belasting of bijvoorbeeld snelle informatisering hebben doorgaans meer baat bij bijscholing. Psychische belasting en snelle informatisering doen zich vooral voor bij hoger opgeleiden en werkenden in hogere beroepen. Omdat een hoge psychische belasting en snelle informatisering in vrijwel elke functie op hoger niveau het risico met zich meebrengen dat men op een gegeven moment de functie die men heeft niet langer kan uitoefenen, is het niet zinvol om aan omscholingstrajecten te denken. Omscholing naar een ander beroep op herzelfde of een hoger niveau neemt immers nauwelijks iets van de risicofactoren weg. Voor deze groepen werkenden ligt bijscholing meer voor de hand. Een training timemanagement bijvoorbeeld zal de psychische belasting mogelijk beperken. Computertrainingen kunnen de negatieve gevolgen van de snelle informatisering indammen. Voor de werkenden die relatief weinig aan scholing doen en ook een geringe functioncle flexibiliteit hebben, is eveneens bijscholing de meest voor de hand liggende methode om zich te wapenen tegen de organisatorische en technologische ontwikkelingen die hun werkzaamheden voortdurend doen veranderen. De bijscholing zal gericht moeten zijn op de veranderende kwalificatievereisten als gevolg van de vernieuwingen watrmee men in het werk wordt geconfronteerd

Daar wata de baanvernietiging voor werkenden als risicofactor is angestipt is enkel omscholing een optie. De kans is immers vrij groot dat de baan waarin men nu werkzaam is op korte termijn zal verdwijnen. Werkenden van wie de baan verdwijnt zijn genoodzaakt een andere baan te zoeken en vaak ook een ander beroep. Omscholingstrajecten kunnen hen daarbij behulpzaam zijn. Welke omscholingstrajecten voor welke groepen werkenden het meest perspectiefrijk zijn komt in het volgende hoofdstuk aan de orde. 


\section{Scholing voor behoud van werk}

\subsection{Inleiding}

In dit hoofdstuk worden de scholingstrajecten belicht die de in hoofdstuk 6 onderscheiden potentiële doelgroepen voor het scholingsbeleid de beste perspectieven bieden op behoud van werk. Er is een drietal risicofactoren op verlies van werk onderscheiden: belastende arbeidsomstandigheden, snelle technologische en organisatorische ontwikkelingen en een krimpende werkgelegenheid. Doelgroepen die te maken hebben met snelle technologische ontwikkelingen zijn het meest gebaat bij bijscholing, zodat ze goed kunnen blijven functioneren in hun huidige functie. Wanneer sprake is van krimpende werkgelegenheid die onder meer het gevolg kan zijn van technologische ontwikkelingen is omscholing of substantiële bijscholing vereist, zodat doelgroepen zich met nieuwe kwalificaties op de arbeidsmarkt kunnen handhaven. Wanneer sprake is van fysiek of psychisch belastende arbeidsomstandigheden, kan zowel bij-als omscholing vereist zijn. Het volgen van scholing moet in dat geval de doelgroepen in staat stellen met de nieuw verkregen vaardigheden de fysieke of psychische belasting te kunnen verminderen, of uit te kunnen wijken naar een ander beroep waarin de arbeidsomstandigheden minder belastend zijn. Omscholing wordt met name actueel wanneer de voortdurende fysieke belasting haar tol al heeft geëist. In dit hoofdstuk komen alleen de in het vorige hoofdsiuk geidentificeerde potentiële doelgroepen aan de orde waarvoor substantiële bijscholing of omscholing vereist is.

De verdere opzet van dit hoofdstuk is als volgt. In paragraaf 7.2 zal een overzicht worden gegeven van beroepsgroepen en opleidingstypen die goede perspectieven bieden voor de in het vorige hoofdstuk geïdentificeerde potentiële doelgroepen voor het scholingsbeleid. Voor beroepen met een grote omscholingsbehoefte zullen beroepen met goede perspectieven worden genoend die een alternatief bieden voor de werkenden in beroepsgroepen die met risico's op verlies van werk worden geconfronteerd. Om op dil punt een realistisch beeld te schetsen wordt er telkens van uitgegaan dat het functieniveau van een uitwijkberoep niet onder het huidige functieniveau ligt en maximaal één functieniveau hoger is. Daarnaast moet er sprake zijn van bepaalde verwantschap tussen het uitwijkberoep en het huidige beroep. Eenzelfde anpak wordt gevolgd bij de opleidingsrichtingen die tot de belangrijkste potentiële doelgroepen van het scholingsbeleid behoren. Hier worden alleen opleidingen als mogelijk omscholingstraject aangeduid als ze maximaal één opleidingsniveau hoger zijn dan het huidige opleidingsniveau van de werkenden en bovendien qua beroependomein enigszins verwant zijn met de opleidingsachtergrond van de desbetreffende potentiële doelgroep van scholingsbeleid.

\subsection{Kansrijke scholingstrajecten}

\section{Beroepen}

In deze paragraaf worden scholingstrajecten aangegeven die aan groepen werkenden die het risico lopen hun baan te verliezen vanwege technische of economische kwalificatie-veroudering goede perspectieven bieden op behoud van werk. De grode pers 
pectieven kunnen zowel in het eigen beroependomein als in aangrenzende uitwijksegmenten liggen. Het gaat hierbij om de in tabel 6.1 genoemde beroepssegmenten waarvoor omscholing vereist is teneinde de arbeidsmarktperspectieven te verbeteren. De potentiële doelgroepen van het scholingsbeleid bevinden zich met name in die beroepssegmenten waar er, gezien de fysieke of psychische belasting, sprake is van zowel tekortschietende scholingsinspanningen als een geringe functionele flexibiliteit van werkenden. Vanwege de over het algemeen gunstige werkgelegenheidsverwachtingen voor de komende jaren, zijn er geen beroepen waarin de scholingsinspanningen en de functionele flexibiliteit van de werkenden tekortschieten met het oog op het risico van verlies van werk dat men loopt als gevolg van de krimpende werkgelegenheid of de relatief grote sectorale reallocatie.

In tabel 7.1 is per beroepssegment aangegeven welke beroepsgroepen de meeste perspectieven bieden voor omscholing. Daarbij wordt een beroepsgroep als perspectiefrijk aangemerkt, wanneer het percentage baanopeningen hoog of erg hoog is en de fysieke belasting geringer is dan in het huidige beroep. Zoals al eerder is opgemerkt, is hierbii rekening gehouden met de verwantschap tussen beroepen en ligt het mogelijke uitwijkberoep maximaal één functieniveau hoger dan het huidige beroep. In de tabel wordt ook een globale indicatie gegeven van de aard van de vereiste additionele vaardigheden waarop de omscholing van een groep werkenden zich zou moeten richten.

Niet voor elk beroepssegment blijki het mogelijk om uit te wijken naar een verwante beroepsgroep, waar betere arbeidsmarktperspectieven gelden en waar bovendien sprake is van een geringere fysieke belasting. Dit geldt bijvoorbeeld voor werkenden in de middelbare juridische, bestumlijke beveiligings-, middelbare verzorgende en bogere (para)mediscbe beroepen

De werkenden in de middelbare verzorgende en de bogere (para)mediscbe beroepen speelt alleen fysieke belasting parten. Omdat voor deze beide beroepssegmenten geen verwante beroepsgroepen met goede perspectieven kunnen worden onderscheiden lijkt gerichte omscholing naar een verwant werkveld geen optie.

Wanneer de werkenden in deze beroepen vanwege de hoge fysieke belasting hun huidige werk niet meer kunnen uitoefenen, zal men zich alleen op de arbeidsmarkt kunnen handhaven, wanneer men wordt omgeschoold naar een geheel ander werkveld. Verlies van werk als gevolg van fysieke slijtage zal voor werkenden in de middelbare lerzorgende en bogere (para)medische beroepen alleen voorkomen kunnen worden door een verbetering van de arbeidsomstandigheden.

Voor de werkenden in de elementaire beroepen bestaat een tweetal perspectiefrijke omscholingstrajecten. In geval van verlies van werk kunnen werkenden in dit beroepssegment uitwijken nat de beroepsgroepen recepionisien en administratieve employeesen verkopers. Om natr deze beroepen te kumnen witwijken hebben de werkenden in de elementaire beroepen scholing nodig die gericht is op een aantal vaardigheden. Met name rekenvardigheden, 'persuasieve' vaardigheden en handvaardigheden zijn hierbij van belang. Het beroep verkoper is overigens voor meerdere beroepssegmenten een mogelijk uitwijkberoep. Ook werkenden in de lagere technische en de lagere verzorgende beroepen kumnen worden ongeschoold tot verkoper. 
Tabel 7.1

Perspectiefrijke omscholingsmogelijkheden voor beroepssegmenten die een potentiële doelgroep zijn voor het scholingsbeleid

\section{Verwante beroepsgroepen \\ met goed perspectief}

Elementaire beroepen

Lagere technische beroepen

Lagere verzorgende beroepen

Middelbare (para) medische beroepen

Middelbare technische beroepen

Middelbare verzorgende beroepen

Hogene technische beroepen

Hogere (para)medische beroepen

$\mathrm{I}=$ codering vaardigheden

1. Kwantitatief

2. Technisch

3. Leidinggevend

4. Organisatie en ordening

5. Verbaal

6. Kunstzinnig

7. Service-gerichtheid

8. Persuasief

9. Handvaardigheden

10. Ruimtelijk voorstellingsvermogen

11. Oplettendheid
Receptionisten en administratieve employees

Verkopers

Verkopers

Verkopers

Boekhouders en secretaresses

Productieplanners

Technisch analisten

Systeenanalisten of toezicht houden. esthetische vormgeving. worden. verhoudingen een rol speelt.

\section{Vereiste additionele vaardigheden ${ }^{1}$}

$02,04,05,08,09,10,11$

$01,06,08,09$

$01,06,08,09$

06

$01,02,03,07,08,11$

04

05

Werkzaamheden waarbij gerekend moet worden.

Het werken met machines en gereedschappen.

Werkzaamheden waarbij sprake is van of beleid voeren, of leidinggeven,

Werkzaanheden waarbij het van belang is de eigen arbeid tot een doelmatig functionerend geheel te ordenen, waronder het overzichtelijk en systematisch opbergen van gereedschappen en materialen.

Werkzaamheden waarbij eisen worden gesteld betreffende het mondeling of schriftelijk weergeven van gedachten en gevoelens.

Werkzaamheden waarbij eisen worden gesteld aan de expressieve of

Werkzaanheden die gericht zijn op dienstverlening aan personen.

Werkzaamheden waarbij mensen in direct contact beinvloed moeten

Werkzaamheden waarbij handmatig of mel eenvoudig handgereedschap producten of delen van producten worden vervaardigd.

Werkzaamheden waarbij het erom gaat zich een voorstelling te maken van ruimtelijkheden en waarbij het schatten van afmetingen en maal-

Werkzaamheden waarbij het van belang is attent te zijn op voor het werk van belang zijinde detaits.

Werkenden in de middelbare (para)medische beroepen kunnen worden omgeschoold tot boekbouder en secretaresse. Mogelijk is dit omscholingstraject alleen interessant voor mediscb secretaresses, een beroepsgroep die deel uitmaakt van het beroepssegment middelbare (para)mediscbe beroepen. De omscholing tot boekhouder of secretaresse vraagt met name scholing op het gebied van kwantitatieve, technische, leidinggevende, service-gerichte en persuasieve vaardigheden. Bovendien wordt wat meer oplettendheid vereist.

In de middelbare en bogere technische beroepen kunnen werkenden zich laten omscho. len tot respectievelijk productieplanner en technisch analist of systeemanalist. Vooral omscholing tot systeemanalist lijkt voor werkenden in de bogere technische beroepen aantrekkelijk, omdat geen additionele vaardigheden worden vereist. Om lechnisch ana- 
list te worden is voor de hogere lechnici additionele scholing op het gebied van de verbale vaardigheden gewenst. Voor de middelbare techniscbe beroepen ligt, zoals gezegd, omscholing tot productieplanner het meest voor de hand. Hiertoe zijn wel additionele vaardigheden vereist op het gebied van organisatie en ordening.

\title{
Opleidingen
}

In deze paragraaf wordt bekeken wat de meest kansrijke scholingstrajecten zijn voor werkenden met één van de opleidingsachtergronden die in hoofdstuk 6 werden bestempeld als de potentiële doelgroepen voor het omscholingsbeleid. Een scholingstraject is kansrijk indien de opleiding verwant is met de opleidingsachtergrond die de om te scholen werknemers momenteel hebben. Bovendien is het realistisch er van uit te gaan dat door substantiële bijscholing of omscholing iemand maximaal één opleidingsniveau hoger kan worden opgeleid. In het overzicht is alleen gekeken naar kansrijke scholingstrajecten voor die groepen werkenden die bij omscholing en/of substantiële bijscholing gebaat zijn.

Uit tabel 7.2 blijkt dat met name de werkenden met slechts basisonderwijs, VMBO zorg en welzijn of een opleiding VMBO techniek grote risico's lopen op verlies van werk Tabel 7.2

Perspectiefrijke omscholingsmogelijkheden voor opleidingsrichtingen die doelgroep zijn voor het scholingsbeleid

\section{Opleidingsrichting}

\section{verwante opleidingstypen met goed perspectief}

\section{Basisonderwijs}

VMBO landbouw en natuurlijke omgeving

VMBO zorg en welzijn

VMBO techniek

MBO techniek

\author{
MBO landbouw en veeteelt \\ HBO civiele techniek
}

door kwalificatieveroudering. Deze groepen behoren tot de belangrijkste doelgroepen voor omscholing c.q. substantiële bijscholing, omdat zij enerzijds te maken hebben met fysiek zwar werk en omdat er anderzijds een hoge baanvernietiging voor lager opgeleiden wordt verwacht. De hoge fysieke belasting zorgt mogelijk voor voortijdig verlies van werk. Als gevolg van de hoge baanvernietiging is het echter moeilijk op hetzelfde niveau weer werk te vinden. Additionele scholing zou hierbij een oplossing zijn, ware het niet dat het werkenden met basisonderwijs, VMBO zorg en weizijn en VMBO techniek ontbreekt aan goede alternatieven. Er worden voor deze opleidingstypen immers geen verwante opleidingstypen gevonden met een goed perspectief of betere arbeidsomstandigheden. Alleen het behalen van een startkwalificatie op MBO-niveau in een niet verwante richting zou voor deze groep werkenden uitkomst kunnen bieden.

Werkenden met een opleiding VMBO landbouw en natuurlike omgeving hebben betere perspectieven. Niveau-verhogende scholing in de vorm van een opleiding $M B O$ landbouw en veeteelt biedt hen de mogelijkheid de risico's waarmee zij in hun huidige functie worden geconfronteerd (baanvernietiging en fysieke belasting) voor een groot deel te ontlopen. 
Voor werkenden met een opleiding MBO techniek speelt alleen een hoge fysieke belasting een rol. Van een hoge baanvernietiging is geen sprake. De omscholing die voor deze groep werkenden het meest voor de hand ligt is een opleiding HBO civiele techniek. Hierbij is wederom sprake van een niveau-verhogende scholing. Omdat de werkenden met een opleiding HBO techniek worden genoend als doelgroep voor bijscholing omdat er voor deze groep sprake is van snelle informatisering, moet tijdens het opleidingstraject mogelijk extra aandacht worden besteed aan computeronderwijs. 


\section{Het werkgelegenheid en scholing obsenvatorium 1996-1999}

Eind 1995 kreeg het ROA van het Ministerie van Sociale Zaken en Werkgelegenheid de opdracht een observatorium op te zetten dat op systematische wijze inzicht zou moeten geven in de maatschappelijke ontwikkelingen die van belang zijn voor het beleid met betrekking tot de scholing van werkenden. Dit Werkgelegenheid en Scholing Observatorium (WSO) zou met name richtinggevende informatie moeten genereren ten behoeve van het scholingsbeleid in het kader van de stimuleringsprogramma's ESF 4 Scholing voor beboud van werk en ADAPT van de Europese Commissie.

Het WSO heeft zich hierbii met name gericht op:

1) het in beeld brengen van de groepen werkenden die het grootste risico lopen hun werk te verliezen als gevolg van kwalificatie-veroudering:

2) het aangeven van de richting waarin de desbetreffende groepen door bijscholing of omscholing hun arbeidsmarktperspectieven weer zouden kunnen verbeteren.

Het WSO heeft in dit kader duidelijk vooruit gelopen op de employability problematiek, die de afgelopen jaren op de beleidsagenda is gekomen. Het in beeld brengen van de risico's die werkenden lopen op verlies van hun werk heeft vanzelfsprekend ook een duidelijke relatie met het in kaart brengen van hun employability, in termen van hun "vermogen om werk te krijgen en te houden" 46 . In het kader van het WSO-project heeft dit onder andere geleid tot een verkenning van de mogelijkheden om te komen tot een Sectorale Employability Index.

Vanuit de optiek van het Werkgelegenheid en Scholing Observatorium is het employability beleid echter slechts een van de afgeleide gebruiksdoelen van de monitoring van de risico's op verlies van werk door kwalificatieveroudering en het in kart brengen van de vereiste bijscholing of kansrijke omscholingstrajecten. Het WSO is immers primair gericht op het transparant maken van de maatschappelijke behoefte aan bij-en omscboling van werkenden en de wijze waarop bier door de markt op wordt ingespeeld. Daarmee dient het met name als leidraad voor het scholingsbeleid gericht op behoud van werk in het algemeen en de daarop toegespitste subsidieverlening in het kader van het ESF 4 in het bijzonder.

In dit kader is de WSO-informatie ook gebruikt bij de discussie over de accenten in de subsidieverlening en de evaluatie van de scholingssubsidies in het kader van ESF 4 door Regioplan ${ }^{17}$. Daarnaast is de informatie door bureau BUESI van het Ministerie van Sociale Zaken en Werkgelegenheid naar buiten gebracht op een studiedag die gericht was op de aanvragers, uitvoerders en administrateurs van lopende en toekomstige ESF 4 projecten $^{78}$. Op deze studiedag is ook een populaire samenvatting van het iweede WSO-overzichtsrapport verspreid: Speerpunten bij de scboling van werkenden.

\footnotetext{
46 Zie Nationaal actieprogramma een leven lang leren', Ministerie van Onderwijs, Cultuur en Weten schappen, Sdu, Den Haag, 1998

47 Regioplan, Eualuatie subsidieregeling ESF-4: scboling voor behoud van werk, 1997

48 BUESI Studiedag ESF 4, bet doet en de middeten, laarbeurs Utrecht. 5 matan 1998.
} 


\section{De ontwikkeling van het WSO}

Het observatorium-karakter van het WSO wordt weerspiegeld in het grote aantal indicatoren dat in de overzichtsrapporten de revue passeert. Deze indicatoren hebben steeds als doel opvallende ontwikkelingen te signaleren met betrekking tot de verschillende risico's op kwalificatieveroudering en de mate waarin hier op wordt ingespeeld door bij- of omscholing. Daarnaast geeft de Statistische Bijlage, bij wijze van naslagwerk, een totaaloverzicht van de in het rapport besproken indicatoren, verbijzonderd naar bedriffsgrootte, bedrijfssector, beroep en opleiding.

Bij de opzet van het WSO is nagestreefd om niet te verzanden in het presenteren van een onsamenhangend geheel van een groot aantal nevengeschikte arbeidsmarktindicatoren. Ook werd beseft dat het weinig zinvol zou zijn eerst een allesomvattend raamwerk te ontwerpen dat in de praktijk niet daadwerkelijk zou kunnen worden ingevuld. Daarom is er voor gekozen om reeds binnen korte tijd een samenhangend stelsel van richtinggevende indicatoren voor het scholingsbeleid naar buiten te brengen, op basis van een duidelijk op de informatiebehoefte voor het scholingsheleid afgestemd denkkader. Deze eerste monitoring is vervolgens stapsgewijs verder uitgebouwd.

In het eerste overzichtsrapport Werkgelegenbeid en scboting 1996 wordt voor het eerst een systematisch overzicht gegeven van de verschillende soorten kwalificatieveroudeing waarmee werkenden te kampen kunnen krijgen. Daarbij is het belangrijke onderscheid gemaakt tussen technische veroudering en economische veroudering (zie hoofdstuk 1). In dit eerste rapport worden overigens alleen indicatoren gepresenteerd die betrekking hebben op de risico's van economische veroudering (kwalificatieveroudering door technologische ontwikkelingen en werkgelegenheidsontwikkelingen). Bovendien vindt er een systematische vergelijking plaats van de verschillende risico's op kwalificatieveroudering en de feitelijke deelname aan scholingsactiviteiten. Op deze wijze kan er een indicatie worden gegeven van de mate waarop er door de markt reeds wordt ingespeeld op de risico's op kwalificatieveroudering en waar op dit punt de lacunes optreden. Interessant is daarbij ook dat relkens wordt verbijzonderd naar bedrijfssector, beroep en de opleidingsachtergrond van de werkenden.

In het tweede overzichtsrapport Werkgelegenheid en scholing 1997 wordt naast de risico's op economische kwalificatieveroudering ook ingegaan op de risico's op verlies van werk vanwege fysiek of psychisch belastende arbeidsomstandigheden. Dit indiceert de behoefte aan omscholing van werkenden die vanwege bepaalde belastingsfactoren op een gegeven moment moeten uitwijken naar ander werk. Daarnaast worden de risico's op kwalificatieveroudering door technologische ontwikkelingen gerelateerd an de organisatorische veranderingen warmee werkenden worden geconfronteerd. Technologische vernieuwingen van het productieproces gaan immers vaak hand in hand met organisatorische veranderingen. Bovendien wordt in dit tweede rapport niet alleen gekeken naar de mate waarin werkenden door scholingsparticipatie hun risico's op kwalificatieveroudering beperken. Ook de employability van de werkenden in de zin van hun functionele flexibiliteit wordt opgevoerd als een factor die tegenwicht kan bieden aan de risico's op verlies van werk door kwalificatieveroudering. 
Dit derde overzichtsrapport Werkgelegenbeid en scholing 1999 geeft opnieuw een integraal overzicht van de verschillende risico's op verlies van werk door kwalificarieveroudering en de mate waarin hieraan tegenwicht wordt geboden door bij- of omscholing of de functionele flexibiliteit waarover werkenden beschikken. In dit rapport zijn, rekening houdend met de uitkomsten van het tweede thema-rapport, de potentiële doelgroepen voor het scholingsbeleid ruimer gedefinieerd. Er is reeds sprake van een potentiële doelgroep voor het scholingsbeleid als of de scholingsparticipatie of de functionele flexibiliteit van de werkenden te weinig tegenwicht biedt aan een bepaald risico op kwalificatie-veroudering. Daarnaast wordt bij het in beeld brengen van de verschillende risico-factoren, waar mogelijk, ook een vergelijking gemaakt met de situatie twee jaar geleden. In enkele hoofdstukken is bovendien geprobeerd de risico's op kwalificatieveroudering met meer specifieke indicatoren in kaart te brengen.

In hoofdstuk 6 wordt een overzicht gegeven van de verschillende bedrijfssectoren, beroepen en opleidingscategorieën die gezien kunnen worden als de belangrijkste doelgroepen voor het scholingsbeleid gericht op het behoud van werk. Bij verschillende doelgroepen spitst de scholingsbehoefte zich toe op een intensivering van de (bij)scholingsactiviteiten die werknemers in staat stellen zich te handhaven in de functie die zij uitoefenen. De bijscholingsbeboefte (in engere zin) waarin de markt in onvoldoende mate voorziet, is opmerkelijk genoeg het grootst bij de hoger opgeleiden.

Bij cle lager opgeleiden is de problematiek echter veel groter. Enerzijds is er een grote behoefte aan substantiële bijscholing bij werkenden met alleen basisonderwijs of een V(M)BO opleiding, die zich alleen in hun beroepsdomein zullen kunnen handhaven wanneer men wordt 'opgeschoold' tot op MBO-niveau. Een dergelijke opscholing kan overigens betrekking hebben op het behalen van deelcertificaten of het certificeren van de buiten formele opleidingen verworven kwalificaties. Men spreekt in dit verband wel van de 'Erkenning van Verworven Competenties' (EVC's). Anderzijds is er bij lager opgeleiden een grote behoefte an omscboling die tegenwicht zou moeten bieden aan de werkgelegenheidskrimp en reallocatieprocessen op de arbeidsmarkt warmee lager opgeleiden vaak worden geconfronteerd en voorziet in de behoefte om uit te wijken naar een ander beroep als men vanwege de hoge fysieke belasting op een gegeven moment de functie die men heeft niet meer kan uitoefenen. Met name ten alanzien van deze omscholingsbehoefte schiet de markt momenteel sterk tekort, vooral wanneer dergelijke scholing gericht moet zijn op functies in een andere bedrijfstak. Dit 'marktfalen kan voor een belangrijk deel verklaard worden door het ontbreken van een maatschappelijke infra-structuur die gericht is op het stimuleren van sector-overstijgende scholing. Samenwerking tussen Opleidings- en Ontwikkelingsfondsen (O\&O fondsen) uit verschillende bedrijfstakken zou een belangrijke schakel kunnen vormen in het bevorderen van omscholingsactiviteiten dic de sector-overstijgende mobiliteit mogelijk maken van mensen die het risico lopen hun huidige functie te verliezen en geen perspectief hebben op een andere functie binnen de bedrijfstak waarin men werkzaam is.

In het WSO-project is, zoals hierboven reeds werd aangegeven, ook een relatie gelegd ussen de fysieke en psychische belasting waarmee mensen in hun werk te maken hebben en het omscholingsbeleid. Daarmee wordt een expliciete relatie gelegd tussen het risico op vervroegde uitstroom uit de arbeidsmarkt vanwege arbeidsongeschiktheid en het scholingsbeleid gericht op het behoud van werk. Ook in dat geval is er meer aan. 
dacht voor sector-overstijgende scholing vereist. In dit kader heeft ook de aandacht voor de RSI-problematiek in dit derde overzichtsrapport een belangrijke signaalfunctie. Dit temeer daar het risico op verlies van werk zich hierbij concentreert op de hoger opgeleiden. Een 'doelgroep' waarvoor tot op heden nog vrijwel geen aandacht is in het scholingsbeleid gericht op behoud van werk.

\section{Thema-rapporten}

In 1998 is geprobeerd het inzicht in het belang van scholing gericht op verlies van werk te verdiepen op basis van een drietal thema-rapporten, die respectievelijk gericht waren op:

- het ontwikkelen van een sectorale employability-index;

- het vergroten van het inzicht in de rol die scholing en een goede employability kunnen spelen bij het voorkomen van kwalificatieveroudering;

- het in kaart brengen van de betekenis van de verschillende veranderingen in een bepaald bedrijf voor de vereiste competenties en het functioneren van de medewerkers die met deze veranderingen worden geconfronteerd, om daarmee het inzicht te verdiepen in de processen die kunnen leiden tot kwalificatieveroudering en de rol die scholing kan spelen om deze kwalificatieveroudering te voorkomen.

Het eerste thema-rapport Employability in bedriff: naar een Employability Index voor bedriffsectoren heeft geleid tot de eerder genoemde Sectorale Employability Index. Deze index geeft naast een algehele beoordeling van de employability van de werkenden in de verschillende bedrijfssectoren, eveneens inzicht in de verschillende aspecten van de employability van werkenden. Het grote voordeel van het benaderen van de employability problematiek vanuit het raamwerk van het WSO is de expliciete aandacht voor de tussen de verschillende bedrijfssectoren en beroepsgroepen uiteenlopende behoefte aan 'emplooibare' werknemers.

Dit maakt het ook mogelijk een scherper beeld te krijgen van het verschillende karakter dat het employability beleid in de verschillende bedrijfssectoren en beroepsgroepen zou moeten krijgen. Zo zal in sommige beroepsterreinen de aandacht primair gericht moeten zijn op het bijblijven in het beroep dat men uitoefent. Dit is vooral het geval bij beroepsgroepen warin de werkenden geconfronteerd worden met snelle technologische vernieuwingen of organisatorische veranderingen (zie hoofdstuk 3). Bii andere beroepsgroepen zal daarentegen het accent moeten liggen op het vergroten van de 'uitwijkmogelijkheden' op de arbeidsmarkt. Dit laatste zal vooral het geval zijn bij beroepsgroepen met een krimpende werkgelegenheid (zie hoofdstuk 4) of beroepen die men vanwege de hoge fysieke of mentale belasting op een bepaald moment niet meer adequaat kan uitoefenen (zie hoofdstuk 2).

Het Ministerie van Sociale Zaken en Werkgelegenheid heeft recentelijk het voortouw genomen voor het opzetten van een Employability Monitor. Deze monitor zal zich niet alleen richten op het in kaart brengen van de employability van de werkenden, maar ook inzicht moeten geven in de employability van de werkloze beroepsbevolking en de mensen die niet participeren op de arbeidsmarkt. 
Het tweede thema-rapport Scholing van werkenden is een nadere studie naar de betekenis van scholingsactiviteiten voor het voorkomen van het risico op kwalificatieveroudering. Uit dit onderzoek komt naar voren dat de in het WSO onderscheiden risicofactoren - slijtage vanwege belastende arbeidsomstandigheden, technologische en organisatorische veranderingen en arbeidsmarktontwikkelingen - inderdaad een oorzaak van kwalificatieveroudering blijken te zijn. De scholing en employability van werkenden blijken echter nauwelijks tegenwicht te bieden aan het risico op verlies van werk vanwege slijtage door belastende arbeidsomstandigheden. Daarentegen blijkt de deelname aan scholing en de employability van werkenden wel een belangrijk middel om kwalificatieveroudering door technologische en organisatorische ontwikkelingen en kwalificatieveroudering vanwege de ontwikkelingen op de arbeidsmarkt te voorkomen.

Het derde thema-rapport Organisatieveranderingen en competentie-ontwikkeling is een minutieuze studie naar de betekenis die de veranderingen binnen een bedrijf hebben gehad voor de kennisveroudering van de medewerkers, de mogelijke gevolgen hiervan en de wijze waarop de vereiste nieuwe competenties in de praktijk worden verworven. Uit het onderzoek komt naar voren dat veranderende regelgeving, ICT-ontwikkelingen en organisatorische veranderingen tot ingrijpende veranderingen van het werk leiden. Het volgen van cursussen blijkt echter slechts een beperkte rol te spelen bij het verwerven van de door deze veranderingen vereiste nieuwe competenties. Werkervaring en contacten met collega's blijken daarentegen veel belangrijker te zijn. Dit wijst er op dat het moeilijk centraal vanuit de organisatie is vast te stellen op welke wijze de competentie-ontwikkeling van de medewerkers het beste ondersteund kan worden. Hieruit kan worden geconcludeerd dat de cursussen die men volgt beter zouden moeten aansluiten bij de problemen die de medewerkers in de organisatie ondervinden. Dit maakt het tevens van groot belang dat werknemers een grotere verantwoordelijkheid krijgen om zelf initiatieven voor hun competentie-ontwikkeling te nemen.

\section{De betekenis van het WSO voor het nieuwe ESF-3}

De herziening van de Europese structuurfondsen in de nieuwe planperiode 2000-2007 plaatst de scholing van werkenden in het bredere kader van het nieuwe ESF-3. Daarloij wordt ook een expliciet verband gelegd met de Europese Werkgelegenheidsstrategie, zoals die tot uiting moet komen in de Nationale Actieplannen Werkgelegenheid. In Nederland zullen er daarbij twee nationale prioriteiten centraal staan:

- Een Activerend arbeidsmarktbeleid gericht op (1) het bestrijden en voorkomen van langdurige werkloosheid en (2) de scholing van werkenden

- Een Leven Lang Leren gericht op de bestrijding van voortijdig schoolverlaten, het versterken van de beroepsbegeleidende leerweg en het praktijkonderwijs.

Het Nationale Actieplan Werkgelegenheid integreert in het kader van het Activerend arbeidsmarktbeleid het scholingsbeleid gericht op (langdurig) werklozen met de scholing van werkenden. Bij de scholing van werkenden gaat het zowel om de scholing van werkenden zonder een startkwalificatie, als om de continue aandacht voor de bij- of omscholing ter voorkoming van het verouderen van hun kennis en vaardigheden. Dit niet alleen vanuit het besef dat moet worden ingespeeld op het tegengaan van de vroegtijdige arbeidsmarktuitstroom van de steeds groter wordende groep oudere arbeidskrachten, maar vooral ook vanuit het besef dat een kenniseconomie een ander human 
resource beleid' vereist, waarin de ontwikkeling en het onderhoud van menselijk kapitaal centraal staan.

De scholing van mensen na het verlaten van het initieel onderwijs speelt daarbij een cruciale rol. In de eerste plaats vereist de toenemende kennisintensiteit van het producticproces in alle bedriffssectoren een upgrading van het kwalificatieniveau van de werkenden. In de tweede plaats ontstaat er een toenemende noodzaak de kwalificatieveroudering vanwege technologische en organisatorische ontwikkelingen en de verschuivingen in de vraag op de arbeidsmarkt te voorkomen door een grotere scholingsparticipatie en het bewerkstelligen van een 'leerrijke werkomgeving:

De scholing gericht op behoud van werk en het bevorderen van de arbeidsmarktinstroom van langdurig werklozen komt hierbij ook in een ander licht te staan. Het scholingsbeleid staat niet langer alleen in het teken van een sociaal beleid ten behoeve van mensen met een zwakkere arbeidsmarktpositie, maar is tevens gericht op de problematiek die zich steeds sterker aan de vraagzijde van de arbeidsmarkt aftekent. Gezien de grote knelpunten in de personeelsvoorziening waarmee werkgevers worden geconfronteerd is het van groot maatschappelijk belang te voorkomen dat er mensen aan de zijlijn blijven of komen te staan, omdat hun kwalificaties niet (langer) toereikend zijn voor de openstaande functies. In dit kader is een integratie van het activerend arbeidsmarktbeleid c.q. scholingsbeleid gericht op werkenden en werklozen erg waardevol. Enerzijds is er ten aanzien van de scholing van werklozen en werkzoekenden een 'curatieve' inhaalslag vereist die mensen in staat stelt werk te krijgen of hun werk te behouden. Anderzijds zal door de voortschrijdende 'vergrijzing' van de beroepsbevolking en de snelle technologische ontwikkelingen - in het kader van een 'preventief' beleid - het voorkomen van kwalificatieveroudering door bij-en omscholing de komende jaren de permanente aandacht vragen.

De monitoring van de verschillende risico's op kwalificatieveroudering, de competentie-ontwikkeling en de loopbaanmogelijkheden van werkenden, werklozen en niet-participerenden die op een gegeven moment weer op de arbeidsmarkt willen herintreden kan daarbij een zeer waardevolle rol spelen. In de eerste plaats biedt een monitoring de mogelijkheid te anticiperen op de verwachte ontwikkelingen op de arbeidsmarkt en de te verwachten gevolgen van de gesignaleerde risico-factoren in een bepaalde sector, beroepsgroep of voor mensen met een bepaalde opleidingsachtergrond. Daarbij kan in het bijzonder in het oog gehouden worden op welke punten er vanuit maatschappelijk oogpunt sprake is van marktfalen vanwege het ontbreken van de juiste 'incentives' bij werkgevers of de werkenden zelf. Op deze manier ontstaat er ook een richtinggevend kader voor het eventueel verstrekken van scholingssubsidies ter voorkoming van werkloosheid of vroegtijdige uittrede uit de arbeidsmarkt.

Bovendien kan een continue monitoring een belangrijke rol spelen bij het vergroten van de bewustwording van de risico's op kwalificatieveroudering bij zowel bedrijven als de werkenden zelf. Deze aanjagende functie voor de scholingsparticipatie zou nog kunnen worden versterkt wanneer de monitoring een benchmark functie gaat vervullen. Als menselijk kapital van even groot belang is als financieel kapitaal. dan verdient het ook hetzelfde instrumentarium. 


\section{Publicaties in het kader van het Werkgelegenheid en Scholing Observatiorium}

\section{Overzichtsrapportages}

A. de Grip, M. van Smoorenburg, L. Borghans, N. Jonker (1997), Werkgelegenbeid en scholing 1996, ROA-R-1997/1, Maastricht 1997.

A. de Grip, M. van Smoorenburg, L. Borghans, N. Jonker, Werkgelegenbeid en scholing 1996, Statistische Bijlage, ROA-R-1997/1B, Maastricht 1997.

ROA, Werkgelegenbeid en scholing 1997, ROA-R-1998/1, Maastricht 1998.

ROA, Werkgelegenbeid en scboling 1997, Statistische Bijlage, ROA-R-1998/1B, Maastricht 1998.

ROA, Werkgelegenheid en scholing 1999, ROA-R-2000/5, Maastricht 2000.

ROA, Werkgelegenbeid en scholing 1999, Statistische Bijlage, ROA-R-2000/5B, Maastricht, 2000.

\section{Themarapporten}

A. de Grip, J. van Loo, I. Sanders, Employability in bedriff: naar een Employability Index voor Bedriffsectoren, ROA-R-1998/10, Maastricht 1998.

A. de Grip, J. van Loo, M. de Steur, Scboling van werkenden, ROA-R-1999/3, Maastricht 1999.

L. Borghans, et, al, Organisatieveranderingen en competentie-ontwikketing: terslag tan een enquête bij het Kantoor, ROA-R-2000/3, Maastricht, 2000.

\section{Methodiek}

A. de Grip, M. van Smoorenburg, L. Borghans, N. Jonker, Methodiek werkgelegenheid en scholing 1996, ROA-W-1997/1, Maastricht 1997.

A. de Grip, J. van Loo, J. Sanders, W. Smits, M. de Steur, R. Welters, Methodiek werkgetegenbeid en scholing 1997, ROA-W-1998/2, Maastricht 1998.

A. de Grip, M. van Smoorenburg, L. Borghans, The Dutch Observatory on Employment and Training. MEANS-Seminar, European Commission DG V, Brussels, ROA-W-1997/2, Maastricht, 1997. 


\section{Nationale en internationale verspreiding resultaten}

Ministerie van Sociale Zaken en Werkgelegenheid/BUESI, Speerpunten bij de scholing van werkenden, Den Haag, 1998.

Ministerie van Sociale Zaken en Werkgelegenheid/BUESI, Spearheads of Employee Training, Den Haag, 1998.

Ministerie van Sociale Zaken en Werkgelegenheid/BUESI, Fers de lance de la formation des personnes actives, Den Haag, 1998.

A. de Grip, J. van LoO, The Dutcb Observatory on Employment and Training, SKOPE Policy Seminar, Oxford, 21 September 1999.

A. de Grip, J. van Loo, J. Sanders, Employability in Action: An Industry Employability Index, SKOPE Research Paper No.5, University of Oxford, Oxford, UK, 1999.

A. de Grip, J. van Loo, J. Sanders, Technologische ontwikkeling en employability, in: CBS, Kennis en Economie 1999, Voorburg, 1999.

A. de Grip, J. van Loo, J. Sanders, Flexibele mensen, flexibele bedrijven, INDEX, no, 1, januari 2000.

\section{Overige publicaties}

N. Jonker, A. de Grip, Do employees with flexible contracts receive less training? ROARM- 1999/1E, Maastricht, 1999.

M. Smoorenburg, A. de Grip, De scholingsinspanning van bedrijven: trainen of werven, in: Economisch Statistische Berichten, jaargang 82, nr. 4127, november 1997, pp. 848849 .

A. de Grip, J. van Loo, Information technology and dynamics on the Dutch labour market, Conference of the European Association of Labour Economists (EALE), Blankenberge, België, 1998.

J. van Loo, A. de Grip, M. de Steur, Skills Obsolescence: Causes and Cures, Conference of the European Association of Labour Economists (EALE), Regensburg, Duitsland, 1999.

A. de Grip, J. van Loo, J. Sanders, Employability in bedrijf: naar een Employability Index voor Bedriffsectoren, Tijdschrift voor Arbeidstraagstukken, jaargang 16, nr. 1, 2000. pp. 6-17.

A. de Grip, J. van Loo, J. Sanders, Employability in Nederland, in: Economisch Statistische Berichten: Jaargang 84, nr. 4189, pp. 116-118. 


\section{Literatuur}

Bartel, A.P. (1991), Productivity gains from the implementation of employee training programs (NBER Working paper series 3893), Cambridge MA: National Bureau of Economic Research.

Bentlage, F.A., J.A.A. Van Duren, L. Franso, P.L.R.M. Van Hooft en G.J.P. Smit (1989), Winst op eigen scboling, resultaten van een onderzoek naar de relatie tussen opleidingsinspanningen en bedriffsprestatie in Nederland, Ministerie van Sociale Zaken, Den Haag.

Blatter, B.M. en P.M. Bongers (1999), Work related neck and upper limb symptoms (RSI): High risk occupations and risk factors in the Dutch working population, TNO Work and Employment, Hoofddorp.

Boer, P. den en T. Reubsaet (1995), Lawaai op de werkplek, een evaluatie van de wetgeving voor scbadelijk geluid op de arbeidsplaats, Ministerie van Sociale Zaken en Werkgelegenheid, Den Haag.

Bolweg, J.F. en G. van Beckhoven, (1995), Employability, een nieuw doel voor de P\&O functie?, Gids voor Personeelsmanagement, nr. 12, pp. $55-57$.

Borghans, L. c.s. (1998), Toekomstverkenning arbeidsmarkt en scboling tot 2007, Ministerie van Sociale Zaken en Werkgelegenheid, Den Haag.

Borghans, L. c.s., (2000), Organisatieveranderingen en competentie-ontwikkeling; Verslag van een enquête bij bet Kantoor; ROA-R-2000/3, Maastricht.

Brouwer, E. en A.H. Kleinknecht (1993), Technologie en de Nederlandse concurrentiepositie: een onderzoek op micro-en meso-niveau, Ministerie van Economische Zaken. Den Haag.

Brouwer, E. en A.H. Kleinknecht (1994), Innotatie in de Nederlandse Industrie en dienstvertening (1992), Ministerie van Economische Zaken, Den Haag.

CBS (1999), Automatiseringsstatistieken, Particuliere sector 1997-1999. Centraal Bureau voor de Statistiek, Voorburg.

Cörvers, F. (1994), Human capital factors at the firm level, ROA-W-1997E, Maastricht.

Delleman, N.J., M.P. van der Grinten en V.H. Hildebrandt (1995), Handmatig. duwen/rekken en gezondbeidseffecten, Ministerie van Sociale Zaken en Wurkgelegenheid, Den Haag.

Dikker, A. (1997), Verplichte bijscholing voorkomt ontslag, PW, 12-7-1997. 
Dikker, A. (1999), P\&O blijft verantwoordelijk voor Arbobeleid, PW, 3-7-1999.

Foss, M.F. (1997), Shiftwork, capital bours and productivity change, Kluwer Academic Publishers, Boston.

Gaspersz, J.B.R. en Ott, M. (1996), Management van Employability. Nieuwe kansen in arbeidsrelaties, Van Gorcum, Assen.

Geiss, Y. (1997), Informatici vinden het snelst een baan op niveau, Computable, 13 juni 1997, nr. 24, pp. 11.

Glasbergen, M.P. (1994), Flexibele en blijuende inzetbaarbeid van macbinebedieners in de grafische industrie, Proefschrift Universiteit Twente, Enschede.

Grip, A. de, J. Van Loo en J. Sanders (1998), Employability in bedriff: Naar een Employability Index voor bedriffsectoren, ROA-R-1998/10, Maastricht.

Grip, A. de, J. Van Loo en M. De Steur (1999), Scboling van werkenden, ROA-R- 1999/3, Maastricht.

Grip, A. de, M. van Smoorenburg, L. Borghans, N. Jonker (1997a), Werkgelegenbeid en scboling 1996, ROA-R-1997/1, Maastricht.

Grip, A. de, M. van Smoorenburg, L. Borghans, N. Jonker (1997b), Werkgelegenbeid en scboling 1996, Statistische Bijlage, ROA-R-1997/1B, Maastricht.

Grip, A. de, L.F.M. Groot (1990), Technologische ontwikkelingen en opleidingseisen in het bankwezen, Tijdschrift voor Arbeidsvraagstukken, volume 6, nr.3, pp. 67-77

Hoeven, W.H.M. van der, A. Kwaak en M.H.C. Lever (1997), Internationalisering, technologische ontwikkeling en arbeidsmarkt. OSA W157, Den Haag

Houtman, I.L.D., A.J. Zuidhof en S.G. van den Heuvel (1998), Arbobeleid in ontwikkeling: werkdruk en RSI de belangrijkste problemen, Ministerie van Sociale Zaken en Werkgelegenheid, Den Haag.

Hulst, N. van, en L. Soete (1989), Export en technologische ontwikkeling in de industrie, In: Preadviezen van de Koninklijke vereniging voor de Staatshuishotalkunde, pp. 63 86, Stenfert-Kroeze. Leiden.

Karasek, R. en T. Theorell (1990), Healtby work: stress, productivity and the reconstruction of working life, Basic Books, New York.

Kessets, I.W.M. (1996), Kemnisproductiviteit, Kluwer Bedriffswetenschappen, Deventer.

Kleinknecht, A. en B. Verspagen (1990), Demand and innovation. Schmookler re-examined, Research Policy, vol. 19, pp. 387-394. 
Kleinknecht, A.H. en R.H. Oostendorp (1998), De invloed van internationalisering op bedrijfsniveau, OSA W161, Den Haag.

Koningsveld, E.A.P. en J.C.M. Mossink (1997), Kernciffers maatschappelijke kosten van arbeidsomstandigheden in Nederland, Ministerie van Sociale Zaken en Werkgelegenheid, Den Haag.

Koning, J. de, M.A. Spierings, C.Th. Zandvliet (1996), Economische aspecten van arbeidsomstandigheden: een literatuminventarisatie in het licht van de behoefte aan relevante beleidsinformatie, Ministerie van Sociale Zaken en Werkgelegenheid, Den Haag.

Kruidenier, H.J. (1980), Het ontbrekende alternatief: een onderzoek naar de persoonsen functiekenmerken van WAO-toetreders, Stichting C.C.O.Z., Amsterdam.

Linden, E. van der (1999), Minder werkdruk in zes stappen, Gids voor Personeelsmanagement, jaargang 78 , nr. 9, pp. 28-31.

Machin, S., A. Ryan en J. Van Reenen (1996), Technology and changes in skill structure: evidence from an international panel of industries, CEPR Discussion Paper No. 297.

Meijman, T.F. (1991), Over vermoeidheid: arbeidspsychologische studies naar de beleving van belastingseffecten, Studiecentrum Arbeid en Gezondheid, Amsterdam.

Miles, I. en K. Ducatel (1994), Technology, occupations and work organization. In: K. Ducatel (Ed.), Employment and technical change in Europe, work organization. skills and training, pp. 154-178, Edward Elgar, Aldershot.

Neuman, S. en A. Weiss (1995), On the effects of schooling vintage on experience-earnings profiles: Theory and evidence, European Economic Review, Volume39, pp. 943 955.

Nordbeck, H. (1998), Wat beweegt Stork? Een concern op weg naar meer mobiliteit. Elsevier bedrijfsinformatie, Den Haag.

Otten, F., P. Bongers en I. Houtman (1998), De kans op RSI in Nederland. Gegevens uit het permanent onderzoek leefsituatie, 1997, Maandbericht gezondbeidsstatistiek, november 1998, CBS, Voorburg/Heerlen.

Pillay, H. (1998), Cognitive skills required in contemporary workplaces, Studies in conlinuing education, 20 (1), 71-81

Popma, J. (1999), Dossier RSI, Samsom, Alphen aan den Rijn.

ROA (1998a), Werkgelegenbeid en Scholing 1997, ROA-R-1998/1, Maastrich1.

ROA (1998b), Werkgelegenheid en Scholing 1997, Statistiscbe Bijlage, ROA-R-1998/1b, Maastricht 
ROA (1999a), De Arbeidsmarkt naar Opleiding en Beroep tot 2004, ROA-R-1999/8, Maastricht.

ROA (1999b), De Arbeidsmarkt naar Opleiding en Beroep tot 2004, Statistische Bijlage, ROA-R-1999/8b, Maastricht.

Salthouse, T.A. (1994), Age related differences in basic cognitive processes: implications for work, Experimental aging research, vol. 20, nr. 4, pp. 249-256.

Singerling, E.P.J. en H.J.M. Mes (1994), Stapsgewijze analyse van employability, Gids voor Personeelsmanagement, nr. 12, pp. 35-40.

Smit, J. (1999), Koffiedik kijken rond IT-bestedingen in 2000, Automatiseringsgids, 3 september 1999, jaargang 33, nr.35.

Smits, W., J. Delmee en A. de Grip (1998), De arbeidsmarkt voor informatici, ROA- R1998/2, Maastricht.

Stroeken, J.H.M. (1993), Informatietechnologie in het bankwezen, in: Horn, L.A. ten, J.H.M. Stroeken en F.R.H. Zijlstra (red.), Informatietechnologie in de maatschappij, wisselwerking, gebruik, sturing, Kluwer Bedrijfswetenschappen, Deventer.

Thijssen, J.G.L. (1996), Leren, leeftijd en loopbaanperspectief, Kluwer Bedrijfswetenschappen, Deventer.

Thijssen, J.G.L. (1997), Employability en employment: terminologie, modelvorming en opleidingspraktijk, Opleiding \& Ontwikkeling, nr. 10, pp. 9-14.

Vos, E. de (1999), Hoogopgeleiden zijn cursusmoe, Intermediair Online, http://www.intermediair.nl/Weekblad/opleidingen/index.html.

Waterreus, J.M. (1997), OGO-fondsen onderzocbt, Max Goote Instituut, Rotterdam

Watkins, K.E. en V.J. Marsick (1993), Sculpting the learning organization, lessons in the art and science of systemic cbange, Jossey-Bass Publishers, San Francisco.

Wissema, J.G., H.M. Messer en G.J. Wijers (1987), Angst voor veranderen? Een mythe! Of: Hoe veranderingsbereidheid op de werkvloer vergroot kan worden, Van Gorcum, Assen/Maastricht.

Wijgaerts, D. (1985), Flexibilisering en deregulering: naar individualisering van de arbeidsverhoudingen? Tijdscbrift vor arbeidstraagstukken, jaargang 1, nr.4. pp. 41- 56. 
